Cochrane Database of Systematic Reviews

\title{
Nitric oxide donors (nitrates), L-arginine, or nitric oxide synthase inhibitors for acute stroke (Review)
}

Bath PMW, Krishnan K, Appleton JP

Bath PMW, Krishnan K, Appleton JP.

Nitric oxide donors (nitrates), L-arginine, or nitric oxide synthase inhibitors for acute stroke.

Cochrane Database of Systematic Reviews 2017, Issue 4. Art. No.: CD000398.

DOI: 10.1002/14651858.CD000398.pub2.

www.cochranelibrary.com

Nitric oxide donors (nitrates), L-arginine, or nitric oxide synthase inhibitors for acute stroke (Review) 
TABLE OF CONTENTS

HEADER

ABSTRACT

PLAIN LANGUAGE SUMMARY

SUMMARY OF FINDINGS

2

BACKGROUND

OBJECTIVES

METHODS

RESULTS

Figure 1.

Figure 2.

Figure 3.

Figure 4.

Figure 5.

DISCUSSION

AUTHORS' CONCLUSIONS

ACKNOWLEDGEMENTS

REFERENCES

CHARACTERISTICS OF STUDIES

DATA AND ANALYSES

Analysis 1.1. Comparison 1 Glyceryl trinitrate (GTN) compared with no GTN for acute stroke, Outcome 1 Death or dependency ( $m R S>2$ ), end of trial.

Analysis 1.2. Comparison 1 Glyceryl trinitrate (GTN) compared with no GTN for acute stroke, Outcome 2 Death or dependency ( $\mathrm{mRS}>2$ ), end of trial, by stroke type.

Analysis 1.3. Comparison 1 Glyceryl trinitrate (GTN) compared with no GTN for acute stroke, Outcome 3 Death or dependency ( $\mathrm{mRS}>2$ ), end of trial, by time to randomisation.

Analysis 1.4. Comparison 1 Glyceryl trinitrate (GTN) compared with no GTN for acute stroke, Outcome 4 Death or dependency ( $m R S>2$ ), end of trial, by baseline SBP.

Analysis 1.5. Comparison 1 Glyceryl trinitrate (GTN) compared with no GTN for acute stroke, Outcome 5 Death or dependency (mean mRS), end of trial.

Analysis 1.6. Comparison 1 Glyceryl trinitrate (GTN) compared with no GTN for acute stroke, Outcome 6 Death or dependency (mean mRS), end of trial, by stroke type.

Analysis 1.7. Comparison 1 Glyceryl trinitrate (GTN) compared with no GTN for acute stroke, Outcome 7 Death or dependency (mean mRS), end of trial, by time to randomisation.

Analysis 1.8. Comparison 1 Glyceryl trinitrate (GTN) compared with no GTN for acute stroke, Outcome 8 Death or dependency (mean $\mathrm{mRS}$ ), end of trial, by baseline SBP.

Analysis 1.9. Comparison 1 Glyceryl trinitrate (GTN) compared with no GTN for acute stroke, Outcome 9 Death, end of treatment.

Analysis 1.10. Comparison 1 Glyceryl trinitrate (GTN) compared with no GTN for acute stroke, Outcome 10 Death, end of treatment, by stroke type.

Analysis 1.11. Comparison 1 Glyceryl trinitrate (GTN) compared with no GTN for acute stroke, Outcome 11 Death, end of treatment, by time to randomisation.

Analysis 1.12. Comparison 1 Glyceryl trinitrate (GTN) compared with no GTN for acute stroke, Outcome 12 Death, end of treatment, by baseline SBP.

Analysis 1.13. Comparison 1 Glyceryl trinitrate (GTN) compared with no GTN for acute stroke, Outcome 13 Death, end of trial. . Analysis 1.14. Comparison 1 Glyceryl trinitrate (GTN) compared with no GTN for acute stroke, Outcome 14 Death, end of trial, by stroke type.

Analysis 1.15. Comparison 1 Glyceryl trinitrate (GTN) compared with no GTN for acute stroke, Outcome 15 Death, end of trial, by time to randomisation.

Analysis 1.16. Comparison 1 Glyceryl trinitrate (GTN) compared with no GTN for acute stroke, Outcome 16 Death, end of trial, by baseline SBP.

Analysis 1.17. Comparison 1 Glyceryl trinitrate (GTN) compared with no GTN for acute stroke, Outcome 17 Neurological deterioration, end of treatment.

Analysis 1.18. Comparison 1 Glyceryl trinitrate (GTN) compared with no GTN for acute stroke, Outcome 18 Neurological deterioration, end of treatment, by stroke type. 
Analysis 1.19. Comparison 1 Glyceryl trinitrate (GTN) compared with no GTN for acute stroke, Outcome 19 Neurological deterioration, end of treatment, by time to randomisation.

Analysis 1.20. Comparison 1 Glyceryl trinitrate (GTN) compared with no GTN for acute stroke, Outcome 20 Neurological deterioration, end of treatment, by baseline SBP.

Analysis 1.21. Comparison 1 Glyceryl trinitrate (GTN) compared with no GTN for acute stroke, Outcome 21 NIH Stroke Scale, end of treatment.

Analysis 1.22. Comparison 1 Glyceryl trinitrate (GTN) compared with no GTN for acute stroke, Outcome 22 NIH Stroke Scale, end of treatment, by stroke type.

Analysis 1.23. Comparison 1 Glyceryl trinitrate (GTN) compared with no GTN for acute stroke, Outcome 23 NIH Stroke Scale, end of treatment, by time to randomisation.

Analysis 1.24. Comparison 1 Glyceryl trinitrate (GTN) compared with no GTN for acute stroke, Outcome 24 NIH Stroke Scale, end of treatment, by baseline SBP.

Analysis 1.25. Comparison 1 Glyceryl trinitrate (GTN) compared with no GTN for acute stroke, Outcome 25 Barthel Index, end of trial.

Analysis 1.26. Comparison 1 Glyceryl trinitrate (GTN) compared with no GTN for acute stroke, Outcome 26 Barthel Index, end of trial, by stroke type.

Analysis 1.27. Comparison 1 Glyceryl trinitrate (GTN) compared with no GTN for acute stroke, Outcome 27 Barthel Index, end of trial, by time to randomisation.

Analysis 1.28. Comparison 1 Glyceryl trinitrate (GTN) compared with no GTN for acute stroke, Outcome 28 Barthel Index, end of trial, by baseline SBP.

Analysis 1.29. Comparison 1 Glyceryl trinitrate (GTN) compared with no GTN for acute stroke, Outcome 29 Mood (Zung), end of trial.

Analysis 1.30. Comparison 1 Glyceryl trinitrate (GTN) compared with no GTN for acute stroke, Outcome 30 Mood (Zung), end of trial, by stroke type.

Analysis 1.31. Comparison 1 Glyceryl trinitrate (GTN) compared with no GTN for acute stroke, Outcome 31 Mood (Zung), end of trial, by time to randomisation.

Analysis 1.32. Comparison 1 Glyceryl trinitrate (GTN) compared with no GTN for acute stroke, Outcome 32 Mood (Zung), end of trial, by baseline SBP.

Analysis 1.33. Comparison 1 Glyceryl trinitrate (GTN) compared with no GTN for acute stroke, Outcome 33 EQ5D-3L, end of trial.

Analysis 1.34. Comparison 1 Glyceryl trinitrate (GTN) compared with no GTN for acute stroke, Outcome 34 EQ5D-3L, end of trial, by stroke type.

Analysis 1.35. Comparison 1 Glyceryl trinitrate (GTN) compared with no GTN for acute stroke, Outcome 35 EQ5D-3L, end of trial, by time to randomisation.

Analysis 1.36. Comparison 1 Glyceryl trinitrate (GTN) compared with no GTN for acute stroke, Outcome 36 EQ5D-3L, end of trial, by baseline SBP.

Analysis 1.37. Comparison 1 Glyceryl trinitrate (GTN) compared with no GTN for acute stroke, Outcome 37 EQ VAS, end of trial. . Analysis 1.38. Comparison 1 Glyceryl trinitrate (GTN) compared with no GTN for acute stroke, Outcome 38 EQ VAS, end of trial, by stroke type.

Analysis 1.39. Comparison 1 Glyceryl trinitrate (GTN) compared with no GTN for acute stroke, Outcome 39 EQ VAS, end of trial, by time to randomisation.

Analysis 1.40. Comparison 1 Glyceryl trinitrate (GTN) compared with no GTN for acute stroke, Outcome 40 EQ VAS, end of trial, by baseline SBP.

Analysis 1.41. Comparison 1 Glyceryl trinitrate (GTN) compared with no GTN for acute stroke, Outcome $41 \mathrm{t}-\mathrm{MMSE}$, end of trial.

Analysis 1.42. Comparison 1 Glyceryl trinitrate (GTN) compared with no GTN for acute stroke, Outcome 42 t-MMSE, end of trial, by stroke type.

Analysis 1.43. Comparison 1 Glyceryl trinitrate (GTN) compared with no GTN for acute stroke, Outcome 43 t-MMSE, end of trial, by time to randomisation.

Analysis 1.44. Comparison 1 Glyceryl trinitrate (GTN) compared with no GTN for acute stroke, Outcome 44 t-MMSE, end of trial, by baseline SBP.

Analysis 1.45. Comparison 1 Glyceryl trinitrate (GTN) compared with no GTN for acute stroke, Outcome 45 TICS, end of trial. ... Analysis 1.46. Comparison 1 Glyceryl trinitrate (GTN) compared with no GTN for acute stroke, Outcome 46 TICS, end of trial, by stroke type.

Analysis 1.47. Comparison 1 Glyceryl trinitrate (GTN) compared with no GTN for acute stroke, Outcome 47 TICS, end of trial, by time to randomisation. 
Analysis 1.48. Comparison 1 Glyceryl trinitrate (GTN) compared with no GTN for acute stroke, Outcome 48 TICS, end of trial, by baseline SBP.

Analysis 1.49. Comparison 1 Glyceryl trinitrate (GTN) compared with no GTN for acute stroke, Outcome 49 Animal naming, end of trial.

Analysis 1.50. Comparison 1 Glyceryl trinitrate (GTN) compared with no GTN for acute stroke, Outcome 50 Animal naming, end of trial, by stroke type.

Analysis 1.51. Comparison 1 Glyceryl trinitrate (GTN) compared with no GTN for acute stroke, Outcome 51 Animal naming, end of trial, by time to randomisation.

Analysis 1.52. Comparison 1 Glyceryl trinitrate (GTN) compared with no GTN for acute stroke, Outcome 52 Animal naming, end of trial, by baseline SBP.

Analysis 1.53. Comparison 1 Glyceryl trinitrate (GTN) compared with no GTN for acute stroke, Outcome 53 Physiotherapy. ..... Analysis 1.54. Comparison 1 Glyceryl trinitrate (GTN) compared with no GTN for acute stroke, Outcome 54 Physiotherapy, by stroke type.

Analysis 1.55. Comparison 1 Glyceryl trinitrate (GTN) compared with no GTN for acute stroke, Outcome 55 Physiotherapy, by time to randomisation.

Analysis 1.56. Comparison 1 Glyceryl trinitrate (GTN) compared with no GTN for acute stroke, Outcome 56 Physiotherapy, by baseline SBP.

Analysis 1.57. Comparison 1 Glyceryl trinitrate (GTN) compared with no GTN for acute stroke, Outcome 57 Occupational therapy.

Analysis 1.58. Comparison 1 Glyceryl trinitrate (GTN) compared with no GTN for acute stroke, Outcome 58 Occupational therapy, by stroke type.

Analysis 1.59. Comparison 1 Glyceryl trinitrate (GTN) compared with no GTN for acute stroke, Outcome 59 Occupational therapy, by time to randomisation.

Analysis 1.60. Comparison 1 Glyceryl trinitrate (GTN) compared with no GTN for acute stroke, Outcome 60 Occupational therapy, by baseline SBP.

Analysis 1.61. Comparison 1 Glyceryl trinitrate (GTN) compared with no GTN for acute stroke, Outcome 61 Speech and language therapy.

Analysis 1.62. Comparison 1 Glyceryl trinitrate (GTN) compared with no GTN for acute stroke, Outcome 62 Speech and language therapy, by stroke type.

Analysis 1.63. Comparison 1 Glyceryl trinitrate (GTN) compared with no GTN for acute stroke, Outcome 63 Speech and language therapy, by time to randomisation.

Analysis 1.64. Comparison 1 Glyceryl trinitrate (GTN) compared with no GTN for acute stroke, Outcome 64 Speech and language therapy, by baseline SBP.

Analysis 1.65. Comparison 1 Glyceryl trinitrate (GTN) compared with no GTN for acute stroke, Outcome 65 Feeding route (nonoral feeding at day 7$)$.

Analysis 1.66. Comparison 1 Glyceryl trinitrate (GTN) compared with no GTN for acute stroke, Outcome 66 Feeding route (nonoral feeding at day 7 ), by stroke type.

Analysis 1.67. Comparison 1 Glyceryl trinitrate (GTN) compared with no GTN for acute stroke, Outcome 67 Feeding route (nonoral feeding at day 7 ), by time to randomisation.

Analysis 1.68. Comparison 1 Glyceryl trinitrate (GTN) compared with no GTN for acute stroke, Outcome 68 Feeding route (nonoral feeding at day 7), by baseline SBP.

Analysis 1.69. Comparison 1 Glyceryl trinitrate (GTN) compared with no GTN for acute stroke, Outcome 69 Length of stay. ..... Analysis 1.70. Comparison 1 Glyceryl trinitrate (GTN) compared with no GTN for acute stroke, Outcome 70 Length of stay, by stroke type.

Analysis 1.71. Comparison 1 Glyceryl trinitrate (GTN) compared with no GTN for acute stroke, Outcome 71 Length of stay by time, to randomisation.

Analysis 1.72. Comparison 1 Glyceryl trinitrate (GTN) compared with no GTN for acute stroke, Outcome 72 Length of stay, by baseline SBP.

Analysis 1.73. Comparison 1 Glyceryl trinitrate (GTN) compared with no GTN for acute stroke, Outcome 73 Headache, on treatment.

Analysis 1.74. Comparison 1 Glyceryl trinitrate (GTN) compared with no GTN for acute stroke, Outcome 74 Headache, on treatment, by stroke type.

Analysis 1.75. Comparison 1 Glyceryl trinitrate (GTN) compared with no GTN for acute stroke, Outcome 75 Headache, on treatment, by time to randomisation.

Analysis 1.76. Comparison 1 Glyceryl trinitrate (GTN) compared with no GTN for acute stroke, Outcome 76 Headache, on treatment, by baseline SBP. 
Analysis 1.77. Comparison 1 Glyceryl trinitrate (GTN) compared with no GTN for acute stroke, Outcome 77 Treatment stopped early.

Analysis 1.78. Comparison 1 Glyceryl trinitrate (GTN) compared with no GTN for acute stroke, Outcome 78 Treatment stopped early, by stroke type.

Analysis 1.79. Comparison 1 Glyceryl trinitrate (GTN) compared with no GTN for acute stroke, Outcome 79 Treatment stopped early, by time to randomisation.

Analysis 1.80. Comparison 1 Glyceryl trinitrate (GTN) compared with no GTN for acute stroke, Outcome 80 Treatment stopped early, by baseline SBP.

Analysis 1.81. Comparison 1 Glyceryl trinitrate (GTN) compared with no GTN for acute stroke, Outcome 81 Systolic BP, first treatment measurement.

Analysis 1.82. Comparison 1 Glyceryl trinitrate (GTN) compared with no GTN for acute stroke, Outcome 82 Systolic BP, first treatment measurement, by stroke type.

Analysis 1.83. Comparison 1 Glyceryl trinitrate (GTN) compared with no GTN for acute stroke, Outcome 83 Systolic BP, first treatment measurement, by time to randomisation.

Analysis 1.84. Comparison 1 Glyceryl trinitrate (GTN) compared with no GTN for acute stroke, Outcome 84 Diastolic BP, first treatment measurement.

Analysis 1.85. Comparison 1 Glyceryl trinitrate (GTN) compared with no GTN for acute stroke, Outcome 85 Diastolic BP, first treatment measurement, by stroke type.

Analysis 1.86. Comparison 1 Glyceryl trinitrate (GTN) compared with no GTN for acute stroke, Outcome 86 Diastolic BP, first treatment measurement, by time to randomisation.

Analysis 1.87. Comparison 1 Glyceryl trinitrate (GTN) compared with no GTN for acute stroke, Outcome 87 Heart rate, first treatment measurement.

Analysis 1.88. Comparison 1 Glyceryl trinitrate (GTN) compared with no GTN for acute stroke, Outcome 88 Heart rate, first treatment measurement, by stroke type.

Analysis 1.89. Comparison 1 Glyceryl trinitrate (GTN) compared with no GTN for acute stroke, Outcome 89 Heart rate, first treatment measurement, by time to randomisation.

APPENDICES

WHAT'S NEW

HISTORY

CONTRIBUTIONS OF AUTHORS 
[Intervention Review]

\section{Nitric oxide donors (nitrates), L-arginine, or nitric oxide synthase inhibitors for acute stroke}

Philip MW Bath ${ }^{1}$, Kailash Krishnan¹, Jason P Appleton ${ }^{1}$

1Stroke, Division of Clinical Neuroscience, University of Nottingham, Nottingham, UK

Contact address: Philip MW Bath, Stroke, Division of Clinical Neuroscience, University of Nottingham, City Hospital Campus, Nottingham, NG5 1PB, UK. philip.bath@nottingham.ac.uk.

Editorial group: Cochrane Stroke Group.

Publication status and date: New search for studies and content updated (conclusions changed), published in Issue 4, 2017.

Citation: Bath PMW, Krishnan K, Appleton JP. Nitric oxide donors (nitrates), L-arginine, or nitric oxide synthase inhibitors for acute stroke. Cochrane Database of Systematic Reviews 2017, Issue 4. Art. No.: CD000398. DOI: 10.1002/14651858.CD000398.pub2.

Copyright @ 2017 The Cochrane Collaboration. Published by John Wiley \& Sons, Ltd.

\section{A B S T R A C T}

\section{Background}

Nitric oxide (NO) has multiple effects that may be beneficial in acute stroke, including lowering blood pressure, and promoting reperfusion and cytoprotection. Some forms of nitric oxide synthase inhibition (NOS-I) may also be beneficial. However, high concentrations of NO are likely to be toxic to brain tissue. This is an update of a Cochrane review first published in 1998, and last updated in 2002.

\section{Objectives}

To assess the safety and efficacy of NO donors, L-arginine, and NOS-I in people with acute stroke.

\section{Search methods}

We searched the Cochrane Stroke Group Trials Register (last searched 6 February 2017), MEDLINE (1966 to June 2016), Embase (1980 to June 2016), ISI Science Citation Indexes (1981 to June 2016), Stroke Trials Registry (searched June 2016), International Standard Randomised Controlled Trial Number (ISRCTN) (searched June 2016), Clinical Trials registry (searched June 2016), and International Clinical Trials Registry Platform (ICTRP) (searched June 2016). Previously, we had contacted drug companies and researchers in the field.

\section{Selection criteria}

Randomised controlled trials comparing nitric oxide donors, L-arginine, or NOS-I versus placebo or open control in people within one week of onset of confirmed stroke.

\section{Data collection and analysis}

Two review authors independently applied the inclusion criteria, assessed trial quality and risk of bias, and extracted data. The review authors cross-checked data and resolved issues through discussion. We obtained published and unpublished data, as available. Data were reported as mean difference (MD) or odds ratio (OR) with 95\% confidence intervals $(\mathrm{CI})$.

\section{Main results}

We included five completed trials, involving 4197 participants; all tested transdermal glyceryl trinitrate (GTN), an NO donor. The assessed risk of bias was low across the included studies; one study was double-blind, one open-label and three were single-blind. All included studies had blinded outcome assessment. Overall, GTN did not improve the primary outcome of death or dependency at the end of trial (modified Rankin Scale (mRS) > 2, OR 0.97, 95\% Cl 0.86 to 1.10, 4195 participants, high-quality evidence). GTN did not improve secondary outcomes, including death (OR $0.78,95 \% \mathrm{Cl} 0.40$ to 1.50 ) and quality of life (MD $-0.01,95 \% \mathrm{Cl}-0.17$ to 0.15 ) at the end of trial overall (highquality evidence). Systolic/diastolic blood pressure (BP) was lower in people treated with GTN (MD $-7.2 \mathrm{mmHg}(95 \% \mathrm{Cl}-8.6$ to -5.9$)$ and $\mathrm{MD}$ 
$-3.3(95 \% \mathrm{Cl}-4.2$ to -2.5$)$ respectively) and heart rate was higher (MD 2.0 beats per minute $(95 \% \mathrm{Cl} 1.1$ to 2.9$)$ ). Headache was more common in those randomised to GTN (OR 2.37, 95\% Cl 1.55 to 3.62). We did not find any trials assessing other nitrates, L-arginine, or NOS-I.

\section{Authors' conclusions}

There is currently insufficient evidence to recommend the use of NO donors, L-arginine or NOS-I in acute stroke, and only one drug (GTN) has been assessed. In people with acute stroke, GTN reduces blood pressure, increases heart rate and headache, but does not alter clinical outcome (all based on high-quality evidence).

\section{PLAIN LANGUAGE SUMMARY}

\section{Nitric oxide donors (nitrates), L-arginine, or nitric oxide synthase inhibitors for acute stroke}

Question: Are nitric oxide donors, L-arginine, or nitric oxide synthase inhibitors safe and effective drugs for use in people soon after they have suffered a stroke?

Background: Nitric oxide is a key molecule involved in the control of blood pressure, blood flow, and brain activity, both before and during a brain attack (stroke, either due to a blockage or rupture of an artery in the brain). Drugs that produce nitric oxide or control its production may be beneficial in acute stroke. This review looked at trials that tested such drugs in people with a stroke that came on within the last few days.

Study characteristics: This review is up-to-date as of September 2016. We included five trials involving 4197 people; all trials assessed glyceryl trinitrate, a drug that is given as a skin patch and which releases nitric oxide. One study was international, whilst the remainder were studies performed at single centres. Not all trials contributed data to all outcomes. We used both unpublished and published information, where available. We did not find any trials assessing other nitrate drugs, L-arginine, or nitric oxide synthase inhibitors.

Key results: Overall, glyceryl trinitrate did not improve the rate of death or dependency compared with those who did not receive glyceryl trinitrate after acute stroke. Glyceryl trinitrate did not improve other outcomes including death and quality of life. Glyceryl trinitrate lowers blood pressure, and increases heart rate and headache in people with acute stroke.

Quality of the evidence: The key results are based on high-quality evidence.

Conclusions: There is currently insufficient evidence to recommend the use of drugs affecting nitric oxide production in acute stroke. Overall, glyceryl trinitrate is inexpensive, lowers blood pressure, increases heart rate and headache, but does not change clinical outcomes in people who have suffered a stroke. 


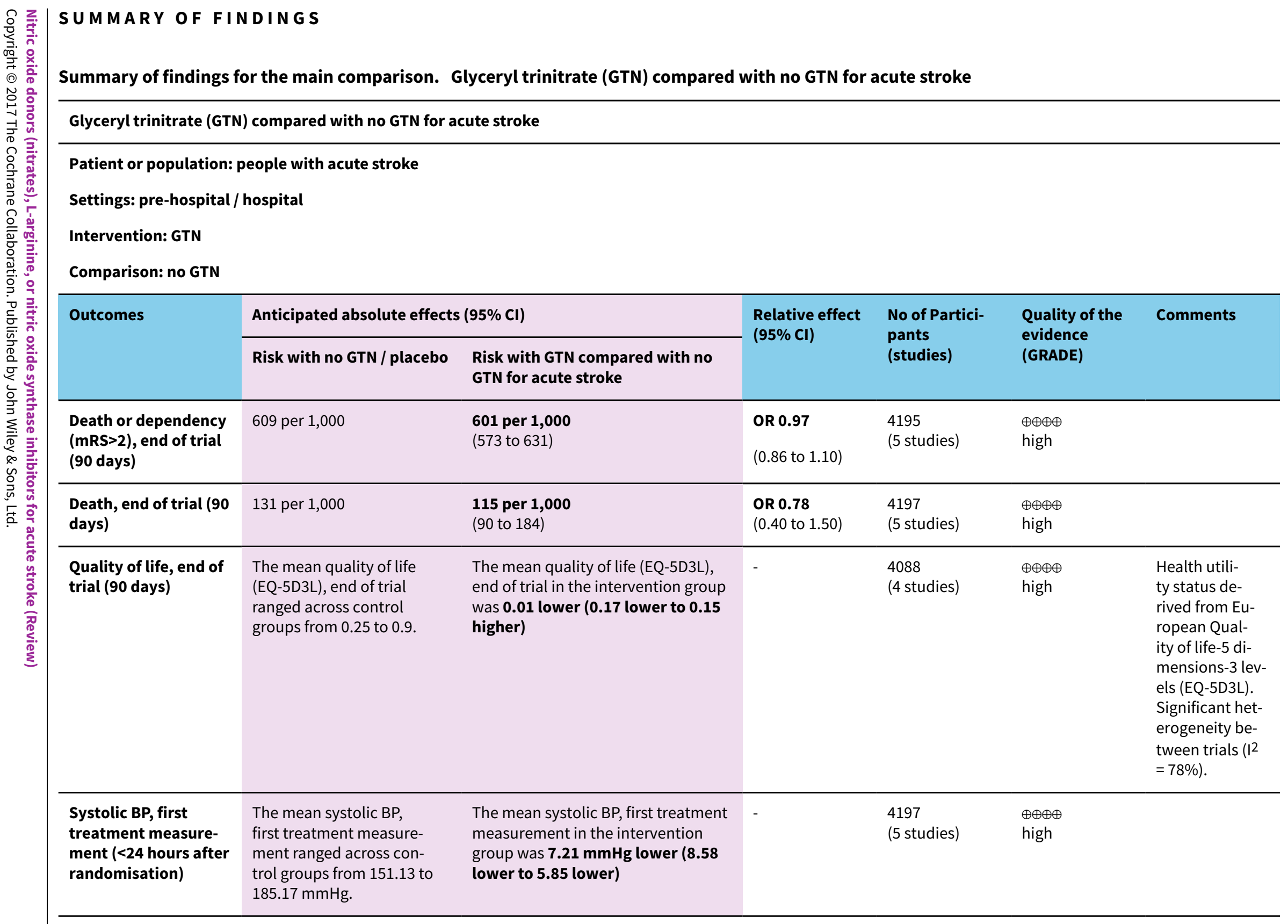




\begin{tabular}{|c|c|c|c|c|c|c|}
\hline $\begin{array}{l}\text { Diastolic BP, first } \\
\text { treatment measure- } \\
\text { ment (<24 hours after } \\
\text { randomisation) }\end{array}$ & $\begin{array}{l}\text { The mean diastolic BP, } \\
\text { first treatment measure- } \\
\text { ment ranged across control } \\
\text { groups from } 82.34 \text { to } 91.0 \\
\mathrm{mmHg} \text {. }\end{array}$ & $\begin{array}{l}\text { The mean diastolic BP, first treat- } \\
\text { ment measurement in the interven- } \\
\text { tion group was } \mathbf{3 . 3 1} \mathbf{~ m m H g} \text { lower } \\
\text { (4.18 lower to } \mathbf{2 . 4 5} \text { lower) }\end{array}$ & - & $\begin{array}{l}4197 \\
\text { (5 studies) }\end{array}$ & $\begin{array}{l}\oplus \oplus \oplus \oplus \\
\text { high }\end{array}$ & \\
\hline $\begin{array}{l}\text { Heart rate, first treat- } \\
\text { ment measurement } \\
\text { (<24 hours after ran- } \\
\text { domisation) }\end{array}$ & $\begin{array}{l}\text { The mean heart rate, first } \\
\text { treatment measurement } \\
\text { ranged across control } \\
\text { groups from } 65.5 \text { to } 77.27 \\
\text { beats per minute. }\end{array}$ & $\begin{array}{l}\text { The mean heart rate, first treatment } \\
\text { measurement in the intervention } \\
\text { group was } 2.02 \text { beats per minute } \\
\text { higher ( } 1.13 \text { higher to } 2.91 \text { higher) }\end{array}$ & - & $\begin{array}{l}4197 \\
\text { (5 studies) }\end{array}$ & $\begin{array}{l}\oplus \oplus \oplus \oplus \\
\text { high }\end{array}$ & $\begin{array}{l}\text { Significant het- } \\
\text { erogeneity be- } \\
\text { tween trials ( } 12 \\
=61 \%) \text {. }\end{array}$ \\
\hline $\begin{array}{l}\text { Adverse event: } \\
\text { Headache, on treat- } \\
\text { ment ( } 7-12 \text { days) }\end{array}$ & 84 per 1,000 & $\begin{array}{l}\mathbf{1 8 0} \text { per } \mathbf{1 , 0 0 0} \\
\text { (125 to } 250)\end{array}$ & $\begin{array}{l}\text { OR } 2.37 \\
\text { (1.55 to } 3.62 \text { ) }\end{array}$ & $\begin{array}{l}4186 \\
\text { (5 studies) }\end{array}$ & $\begin{array}{l}\oplus \oplus \oplus \oplus \\
\text { high }\end{array}$ & \\
\hline
\end{tabular}

BP: blood pressure; Cl: confidence interval; GTN: glyceryl trinitrate; MD: mean difference; OR: odds ratio

GRADE Working Group grades of evidence

High quality: Further research is very unlikely to change our confidence in the estimate of effect.

Moderate quality: Further research is likely to have an important impact on our confidence in the estimate of effect and may change the estimate.

Low quality: Further research is very likely to have an important impact on our confidence in the estimate of effect and is likely to change the estimate.

Very low quality: We are very uncertain about the estimate. 


\section{B A C K G R O U N D}

\section{Description of the condition}

Stroke is the third most common cause of death and the most common cause of disability in the western world (Mackay 2004). Blood pressure (BP) is elevated in $75 \%$, or more, of people with acute stroke (whether due to blockage (ischaemic stroke) or rupture (intracerebral haemorrhage (ICH)) of an artery), and half of those have an existing diagnosis of hypertension (Britton 1986; Oppenheimer 1992). In two-thirds of people with stroke, BP spontaneously falls in the first week after stroke, whilst the remainder have high BP, which is associated with a poor outcome (Willmot 2004). Systolic BP is related to outcome in a 'U-shaped' relationship with both high and low systolic BP associated with increased death, and death or dependency (Leonardi-Bee 2002). Elevated systolic BP is also associated with early stroke recurrence (Sprigg 2006).

Cerebral autoregulation maintains cerebral blood flow (CBF) despite changes in cerebral perfusion pressure (CPP: blood pressure supplying the brain). In acute stroke, autoregulation is lost so that cerebral perfusion becomes related to CPP, and therefore systemic BP (Tikhonoff 2009). Thus, large and precipitous reductions in $\mathrm{BP}$ reduce $\mathrm{CBF}$, leading to further cerebral infarction (brain cell death from lack of blood flow; Owens 2011) or perihaematomal ischaemia (reduced blood flow to brain tissue surrounding the ICH; Qureshi 2008). Similarly, high BP increases the risk of haematoma (bleed) growth in $\mathrm{ICH}$, haemorrhagic transformation in ischaemic stroke, and cerebral oedema (brain swelling) in both stroke types (Fagan 1998; Willmot 2004).

\section{Description of the intervention}

Nitric oxide (NO) (endothelium-derived relaxing factor) is an endogenous (present within humans) inorganic soluble gas formed from the guanidino nitrogen of L-arginine and molecular oxygen by the enzyme (catalyst) nitric oxide synthase (NOS) (Palmer 1987; Palmer 1988). This enzyme is present within endothelial cells (endothelial NOS, eNOS, type III NOS) and some neurones (brain cells; neuronal NOS, nNOS, type I NOS) in a calcium-dependent constitutive form (Knowles 1989), and in macrophages (white blood cells), astrocytes, microglia (brain cells), and vascular smooth muscle cells (inducible NOS, iNOS, type II NOS) in a calciumindependent inducible form (Fleming 1991; Cho 1992). NO is one of the most versatile molecules in animal and human biology with diverse roles in both physiology and pathophysiology: it is a vasodilator (dilates blood vessels) with anti-smooth muscle cell activity (Murad 1987); protects endothelium; inhibits platelet (circulating cell fragments involved in clotting) adhesion and aggregation (Radomski 1987a; Radomski 1987b) and leucocyte (white blood cells) adhesion and chemotaxis (movement of cells to an attractant) (Bath 1991), and has other anti-inflammatory properties. Further, it is a neurotransmitter and neuromodulator (chemical messenger) (Garthwaite 1988; Manzoni 1992; Dawson 1994), and is involved in cerebral blood flow auto- and chemoregulation (control of brain blood flow) (Tanaka 1996; White 2000; Lavi 2003).

In experimental pre-clinical studies of ischaemic stroke, significant changes relating to NO occur in a time-dependent fashion. In models of focal ischaemic stroke, there is increased NO production for up to 30 minutes following middle cerebral artery occlusion or blockage (Kader 1993; Malinski 1993), likely due to increased calcium availability and nNOS activation (Huang 1994). eNOS and nNOS activity increases in line with NO within the first minutes following middle cerebral artery occlusion and significantly reduces thereafter (Kader 1993), whilst iNOS is upregulated (increased activity) from 12 hours after the event, this lasting for up to seven days (Niwa 2001). Within brain tissue, NO is undetectable for up to seven days following ictus (stroke onset) (Malinski 1993).

Intravenous (injected into a vein) L-arginine given after middle cerebral artery occlusion improved cerebral blood flow within the ischaemic penumbra (area of brain tissue surrounding the infarct that is at risk of infarction) and reduced infarct size and volume (Morikawa 1992a; Morikawa 1994). However, this observation was not seen in eNOS-deficient mice, who also have lower post-ischaemic cerebral blood flow, larger infarcts, smaller penumbral areas (Huang 1996; Lo 1996), and absent angiogenesis (development of new blood vessels), potentially leading to increased post-ischaemic damage (Cui 2009). The advantageous effects of eNOS activity are supported by evidence that eNOS phosphorylation-deficient mice (mice with inactive eNOS) (Atochin 2007) and mice deficient in the alpha-1 subunit of soluble guanylate cyclase have increased infarct size (Atochin 2010). Whilst eNOS and eNOS-derived NO are neuroprotective (protecting brain cells against further damage) following cerebral infarction, nNOS-derived NO (Huang 1994; Hara 1996; Zaharchuk 1997) and iNOS-derived NO (ladecola 1995; Zhang 1996; Iadecola 1997; Zhao 2003) are detrimental to tissue survival resulting in poorer neurological outcome. Despite being neurotoxic in the acute phase following stroke, iNOS and nNOS seem to be important in neurogenesis (formation of new brain cells) post-stroke, with iNOS promoting (Sehara 2006; Corsani 2008) and nNOS attenuating this process (Sun 2005).

With the weight of evidence for NO-mediated neuroprotection post-stroke, several therapeutic strategies have been proposed: replacement or supplementation of NO deficiency through administration of NO, NO donors or precursors; enhancement of eNOS activity to modulate or increase endogenous NO production (Endres 2004); and direct or indirect inhibition of NOS.

\section{How the intervention might work}

Vascular NO levels are low in acute stroke and so replacement might be beneficial (Ferlito 1998; Rashid 2003). NO, however delivered, may have multiple effects that could improve outcome after stroke.

- BP lowering: NO donors (intravenous sodium nitroprusside (SNP) and transdermal glyceryl trinitrate (GTN)) lower BP, pulse pressure, and peak systolic BP; improve arterial compliance; and maintain CBF in acute stroke (Butterworth 1998; Bath 2001; Rashid 2002; Willmot 2006). Whilst SNP inhibits platelet function, thereby negating its use in ICH (Butterworth 1998), GTN has no effect on platelets and can therefore be used in people with stroke, regardless of stroke type (Bath 2001).

- Reperfusion (improving blood supply): NO dilates cerebral arteries and could then increase perilesional perfusion (blood flow around the stroke lesion via the 'front door') without inducing cerebral steal (Willmot 2006). Pial artery (brain surface artery) blood flow and, therefore, collateral flow may provide 'back-door' reperfusion to the ischaemic penumbra in ischaemic stroke (Morikawa 1992b) and the perihaematomal region in $\mathrm{ICH}$. 
- Cytoprotection (cell protection): NO exhibits neuroprotective effects, as found in experimental studies (see above). Whether these effects involve cellular protection per se or just reflect reperfusion remains unclear.

NO donors could also have adjunctive effects, enhancing the effects of existing reperfusion therapies by:

- Lowering BP: NO donors may prepare people with hyper-acute (within a few hours) ischaemic stroke for thrombolysis (clotdissolving therapy; non-significant tendencies to more and earlier intravenous thrombolysis were seen in the pilot RIGHT trial (Ankolekar 2013);

- Dilating cerebral arteries around occluding clot, NO donors may enhance access to the clot by both endogenous and exogenous fibrinolysis (clot-dissolving compounds found within the body and administered as treatment).

\section{Why it is important to do this review}

Evidence-based treatments for acute stroke are limited. In hyperacute ischaemic stroke, there are interventions with high efficacy but limited utility (intravenous thrombolysis (Emberson 2014); thrombectomy (removal of clot causing large vessel occlusion) (Goyal 2016); and decompressive hemicraniectomy (surgery to remove one side of the skull to relieve intracranial pressure) (Vahedi 2007)), and those with low efficacy but high utility (aspirin (Sandercock 2014)). In comparison, there are no definitive treatments for ICH other than early BP lowering (Anderson 2013). All patients with stroke should have access to stroke unit care (Stroke Unit Trialists' Collaboration 2013).

NO donors are inexpensive (e.g. GTN costs approximately $£ 1$ per patch) and, if efficacious, could be used in low, middle, and high income economies.

\section{OB JECTIVES}

To assess the safety and efficacy of NO donors, L-arginine, or NOSI in people with acute stroke.

\section{METHODS}

\section{Criteria for considering studies for this review Types of studies}

Published and unpublished randomised controlled trials (RCTs) of NO donors, L-arginine, or NOS-I in people with stroke randomised within one week of ictus with either acute ischaemic stroke or $\mathrm{ICH}$. We excluded studies of people with subarachnoid haemorrhage, uncontrolled studies, and confounded controlled studies (i.e. where two or more active interventions were compared).

\section{Types of participants}

Men and women of any age with recent ischaemic stroke or intracerebral haemorrhage (ICH) eligible for randomisation to active treatment or control.

\section{Types of interventions}

NO donors, L-arginine, and/or NOS-I given by any route of administration versus placebo or open control.

\section{Types of outcome measures}

We assessed haemodynamic measures after first treatment, and clinical measures at end of treatment and end of follow-up.

\section{Primary outcomes}

End-of-trial death or dependency, defined as modified Rankin Scale $(m R S)>2$. The $m R S$ is a 7-level ordinal hierarchical scale ascribing a score to grades of disability from 0: no symptoms; 1 : symptoms but independent; 2: mostly independent but needs some help; 3 : moderate dependency but can walk; 4: dependency needing help for walking and bodily needs; 5 : severe dependency and bedridden; and 6: death.

\section{Secondary outcomes}

- First blood pressure and heart rate measurements after randomisation

- Early case fatality (end of treatment)

- Late case fatality (end of trial)

- Early neurological deterioration by end of treatment defined as a decrease in the Scandinavian Stroke Scale (SSS) by $>5$ points or a decrease in the consciousness part of the SSS by $>2$ points

- Headache on treatment

- Treatment stopped early

- National Institutes of Health Stroke Scale (NIHSS) at end of treatment derived from SSS (Gray 2009)

- Late dependency or disability defined as end-of-trial Barthel Index (BI)

- Mood at end-of-trial using the short-form Zung Depression Scale (Zung 1965)

- Quality of life at end-of-trial using health utility status derived from European Quality of life-5 dimensions-3 levels (EQ-5D3L) and EQ-visual analogue scale (EQ-VAS)

- Cognition at end-of-trial using telephone Mini-Mental State Examination (t-MMSE, subscore derived from MMSE), telephone interview cognition scale (TICS) and verbal fluency (animal naming)

- Physiotherapy during hospital stay

- Occupational therapy during hospital stay

- Speech and language therapy during hospital stay

- Feeding route (non-oral feeding at day seven)

- Length of hospital stay (days)

\section{Search methods for identification of studies}

See the 'Specialized register' section in the Cochrane Stroke Group module. We did not apply any language restrictions and sought translations of articles where required.

\section{Electronic searches}

We searched the Cochrane Stroke Group Trials Register (last searched 6 February 2017), MEDLINE (Ovid) (1966 to June 2016, Appendix 1), Embase (Ovid) (1980 to June 2016, Appendix 2), Science Citation Index (ISI, Web of Science, 1900 to June 2016, Appendix 3), Stroke Trials Registry (www.strokecenter.org/ trials, searched June 2016), International Standard Randomised Controlled Trial Number (ISRCTN) registry (www.controlledtrials.com, searched June 2016), Clinical Trials registry (www.clinicaltrials.gov, searched June 2016), and the International 
Clinical Trials Registry Platform (ICTRP) (www.apps.who.int/ trialsearch/, searched June 2016).

\section{Searching other resources}

For the 2002 version of this review we contacted pharmaceutical companies who made nitric oxide donors (Schwarz Pharma, Schering-Plough) or nitric oxide synthase inhibitors (GlaxoWellcome) and researchers in the field to help identify relevant trials (Bath 2002). For this update, we also searched references lists of included studies and systematic reviews.

\section{Data collection and analysis}

We extracted data using a standard proforma, which one review author (JA) entered into Review Manager 5 (RevMan 2014) and another review author (KK) checked.

\section{Selection of studies}

One author (JA) screened the outputs from the electronic searches, and excluded irrelevant studies. We obtained full paper copies of the remaining studies and both review authors (JA and PB) selected studies based on the aforementioned inclusion criteria. We resolved any disagreements through discussion.

\section{Data extraction and management}

We extracted data from published and unpublished material. We recorded information on the following parameters: randomisation method; allocation concealment; blinding of treatment; analysis method; stroke type; treatment type, dose, route of administration and timing; blood pressure and heart rate during treatment; case fatality; functional status; quality of life; mood; cognition; length of hospital stay; rates of physiotherapy, occupational therapy and speech and language therapy; and feeding status. Individual patient data were available for all included trials and this allowed subgroup analyses and calculation of means and standard deviations to facilitate parametric analyses of ordinal outcomes such as mRS. The search criteria did not require that individual patient data were present in the included studies.

\section{Assessment of risk of bias in included studies}

We assessed risk of bias in the included studies using Cochrane's 'Risk of bias' tool, which is based on the following domains:

- Random sequence generation.

- Allocation concealment.

- Blinding of participants and personnel.

- Blinding of outcome assessment.

- Incomplete outcome data.

- Selective reporting.

- Other sources of bias.

Each domain includes one or more specific entries in a 'Risk of bias' table. Within each entry, the first part of the tool describes what was reported to have happened in the study in sufficient detail to support a judgement on the risk of bias. The second part assigns a judgement relating to the risk of bias: 'Low risk' of bias, 'High risk' of bias, or 'Unclear risk' of bias, according to the Cochrane Handbook for Systematic Reviews of Interventions (Higgins 2011).

\section{Measures of treatment effect}

We calculated the weighted estimate of the typical treatment effect across trials using RevMan 5.3 (RevMan 2014). We calculated odds ratios (OR) using the Mantel-Haenszel random-effects model for binary data, and mean difference (MD) using the inverse variance method for continuous data, all with $95 \%$ confidence intervals (Cls).

\section{Unit of analysis issues}

Where stroke severity was measured by the Scaninavian Stroke Scale (SSS), the National Institutes of Health Stroke Scale (NIHSS) score was calculated using a published conversion algorithm (Gray 2009). Since many scales include a value for people who have died (e.g. modified Rankin Scale $=6$, Health Utility Status $=0$, Barthel Index $=-5$ ), extreme worst values were assigned for death for other outcomes including mood (short-form Zung Depression Scale (Zung 1965) = 102.5; EQ-VAS = -1; t-MMSE = -1 ; TICS = -1 ; and animal naming $=-1$ ). Where secondary outcomes were not assessed, trials were excluded from analysis of that particular outcome.

\section{Dealing with missing data}

We made extensive attempts to find missing data, including utilising unpublished data from study authors.

\section{Assessment of heterogeneity}

We calculated heterogeneity between RCT results using the $1^{2}$ statistic based upon the DerSimonian-Laird formula (DerSimonian 1986).

\section{Assessment of reporting biases}

We demonstrated reporting bias using funnel plots.

\section{Data synthesis}

We performed statistical analysis using RevMan 5.3 (RevMan 2014). We reported outcomes for dichotomous data as OR with $95 \% \mathrm{Cls}$, and continuous data as MD with $95 \% \mathrm{Cls}$. We used random-effects models to analyse individual results, a conservative approach appropriate for the heterogenous designs and populations of the trials involved. We used fixed-effect models to analyse haemodynamic variables, given the size and precision of ENOS 2015 in relation to the other included studies.

\section{Summary of findings table}

We presented the primary outcome and important secondary outcomes (including quality of life) of the review in Summary of findings for the main comparison. We used the GRADE approach to assess the quality of the supporting evidence for each analysis. We downgraded quality depending upon: limitations in study design and implementation suggesting a high potential of bias; unexplained heterogeneity or inconsistency of results; imprecision of results (wide $\mathrm{Cls}$ ); indirectness of evidence; or publication bias.

\section{Subgroup analysis and investigation of heterogeneity}

We reviewed the primary and secondary outcomes in the following prespecified subgroups.

- Intervention type

- Type of stroke: ischaemic stroke or ICH

- Time from stroke onset to randomisation: $\leq 6$ hours; 6.1 to 12 hours; 12.1 to 24 hours; 24.1 to 36 hours; and $>36$ hours 
- Baseline systolic blood pressure (systolic BP): $\leq 160 \mathrm{mmHg}$; 160.1 to $180 \mathrm{mmHg}$; 180.1 to $200 \mathrm{mmHg}$; $200 \mathrm{mmHg}$

We considered heterogeneity to be significant if 12 was greater than $50 \%$; if present, we sought the potential reasons, e.g. different trial designs, trial populations, time to treatment. If individual subgroups had zero participants in either the intervention or no intervention arms, then we excluded the trial concerned from that particular individual subgroup analysis. As a result, the denominators for subgroups analyses vary.

\section{Sensitivity analysis}

Since ordinal or continuous analyses are more sensitive to treatment effects than dichotomous measures (OAST 2007), we assessed the comparison of the primary outcome, $\mathrm{mRS}$, as MD in addition to OR.

\section{RES U L T S}

\section{Description of studies}

We included five randomised trials of participants with ultra-acute, hyper-acute, acute and sub-acute stroke.

\section{Results of the search}

Figure 1 shows the PRISMA study flow diagram. Of the 4772 records identified and screened, we excluded 4750. After full-text review of the remaining 22 studies, we excluded 16 studies including four ongoing studies that did not meet eligibility criteria. One study met inclusion criteria but is currently ongoing. Therefore, we included five trials, which are completed and summarised in Characteristics of included studies. 
Figure 1. Results of Database Search

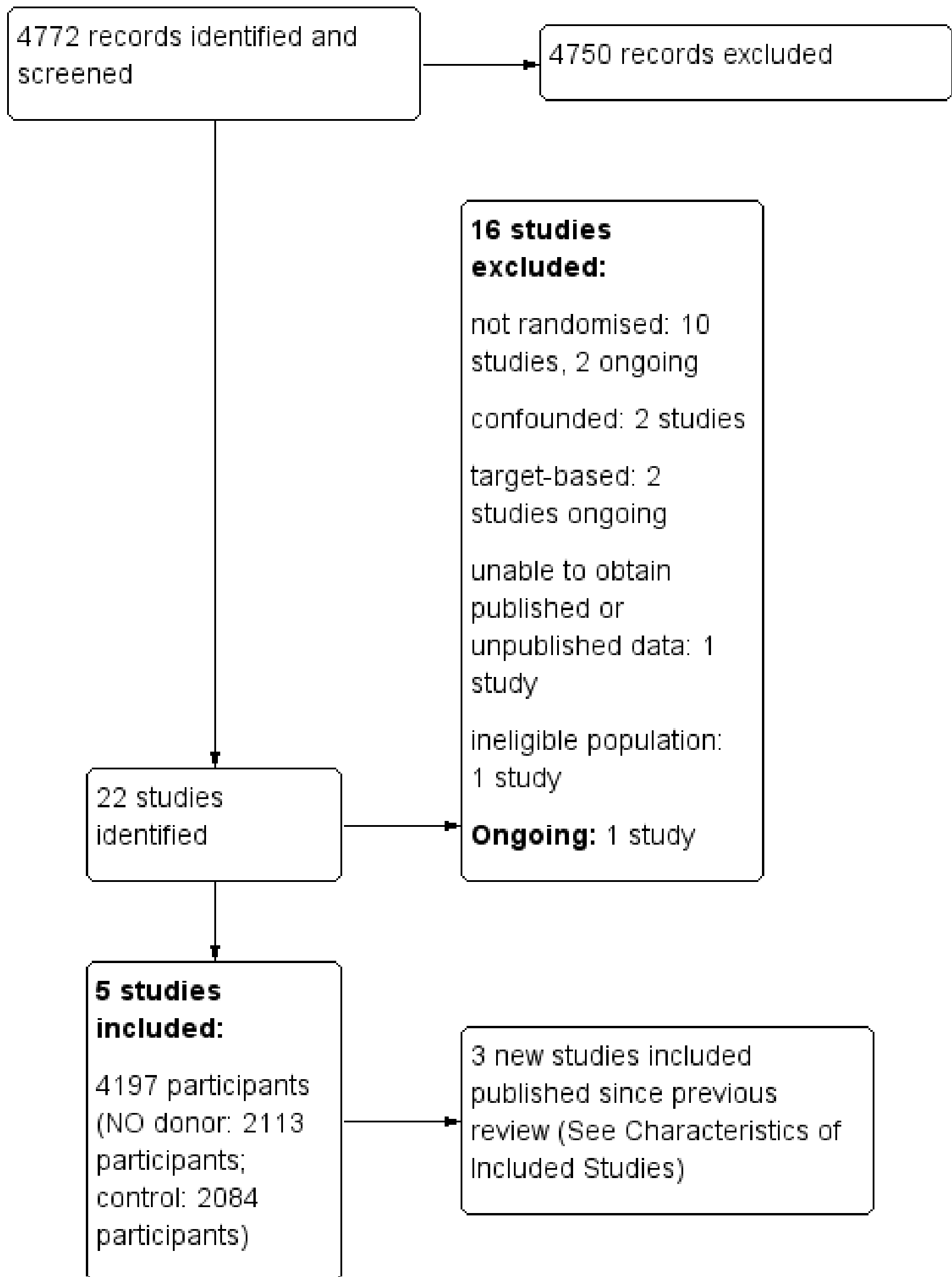




\section{Included studies}

We identified five trials that fulfilled the inclusion criteria (Ankolekar 2013; Bath 2001; ENOS 2015; Rashid 2002; Willmot 2006). All five trials involved administration of transdermal glyceryl trinitrate (GTN) 5 to $10 \mathrm{mg}$ daily via a patch. Individual patient data were provided for all five studies, totaling 4197 participants. All studies recruited participants with mixed stroke (ischaemic stroke and $\mathrm{ICH}$ ). One of the trials was multicentre and international (ENOS 2015), whilst the remainder were UK-based, single-centre studies.

Trial recruitment occurred at different time intervals following stroke:

- within four hours of onset (Ankolekar 2013);

- within 48 hours of onset (ENOS 2015);

- within 72 hours of onset (Rashid 2002);

- within 168 hours of onset (Bath 2001; Willmot 2006).

The duration of the intervention period varied:

- seven days (Ankolekar 2013; ENOS 2015; Willmot 2006);

- 10 days (Rashid 2002);

- 12 days (Bath 2001).

Four studies used transdermal GTN patch $5 \mathrm{mg}$ once daily (Ankolekar 2013; Bath 2001; ENOS 2015; Willmot 2006), whilst Rashid 2002 adopted a different strategy with three treatment groups: transdermal GTN patch $5 \mathrm{mg}$ once daily for 10 days; $5 \mathrm{mg}$ for four days then $10 \mathrm{mg}$ for six days; and $10 \mathrm{mg}$ for 10 days. For this review, as with a previous version (2002), we combined the three treatment arms into one group. All studies detailed the equipment used and patient posture when blood pressure recordings were performed.

Multiple outcomes were reported:
- mRS end-of-trial in all studies (Ankolekar 2013; Bath 2001; ENOS 2015; Rashid 2002; Willmot 2006);

- BI end-of-trial in all studies (Ankolekar 2013; Bath 2001; ENOS 2015; Rashid 2002; Willmot 2006);

- case fatality at end-of-treatment and end-of-trial in all studies (Ankolekar 2013; Bath 2001; ENOS 2015; Rashid 2002; Willmot 2006);

- early neurological deterioration by end-of-treatment in four studies (Ankolekar 2013; ENOS 2015; Rashid 2002; Willmot 2006);

- mood (Zung Depression Scale) end-of-trial in three studies (Ankolekar 2013; ENOS 2015; Willmot 2006);

- quality of life (EQ-5D and EQ-VAS) end-of-trial in four studies (Ankolekar 2013; ENOS 2015; Rashid 2002; Willmot 2006);

- cognition at end-of-trial in three studies: MMSE (Ankolekar 2013; Willmot 2006), t-MMSE (ENOS 2015), TICS (ENOS 2015), animal naming (ENOS 2015);

- physiotherapy, occupational therapy and speech and language therapy rates in three studies (Ankolekar 2013; ENOS 2015; Willmot 2006);

- feeding route (non-oral feeding at day seven) in three studies (Ankolekar 2013; ENOS 2015; Willmot 2006);

- length of stay in four studies (Ankolekar 2013; Bath 2001; ENOS 2015; Willmot 2006).

\section{Excluded studies}

We excluded 16 studies that either lacked randomisation, were uncontrolled, were confounded, or were not relevant to this review (Characteristics of excluded studies); four of these are ongoing studies. One other study met the inclusion criteria and is currently ongoing (Characteristics of ongoing studies).

\section{Risk of bias in included studies}

For full details see the corresponding 'Risk of bias' tables in Characteristics of included studies, and Figure 2 and Figure 3.

Figure 2. Risk of bias graph: review authors' judgements about each risk of bias item presented as percentages across all included studies.

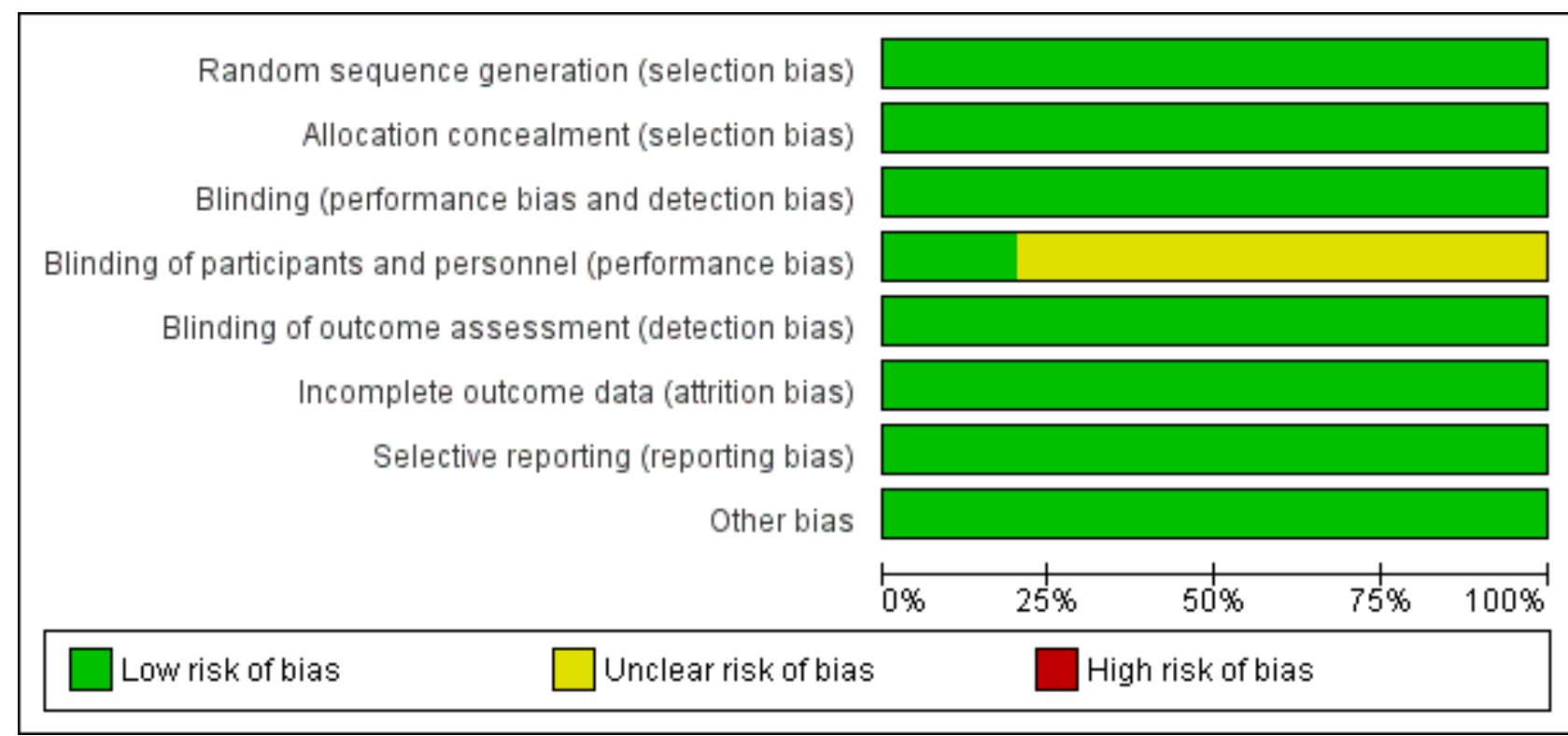


Figure 3. Risk of bias summary: review authors' judgements about each risk of bias item for each included study.

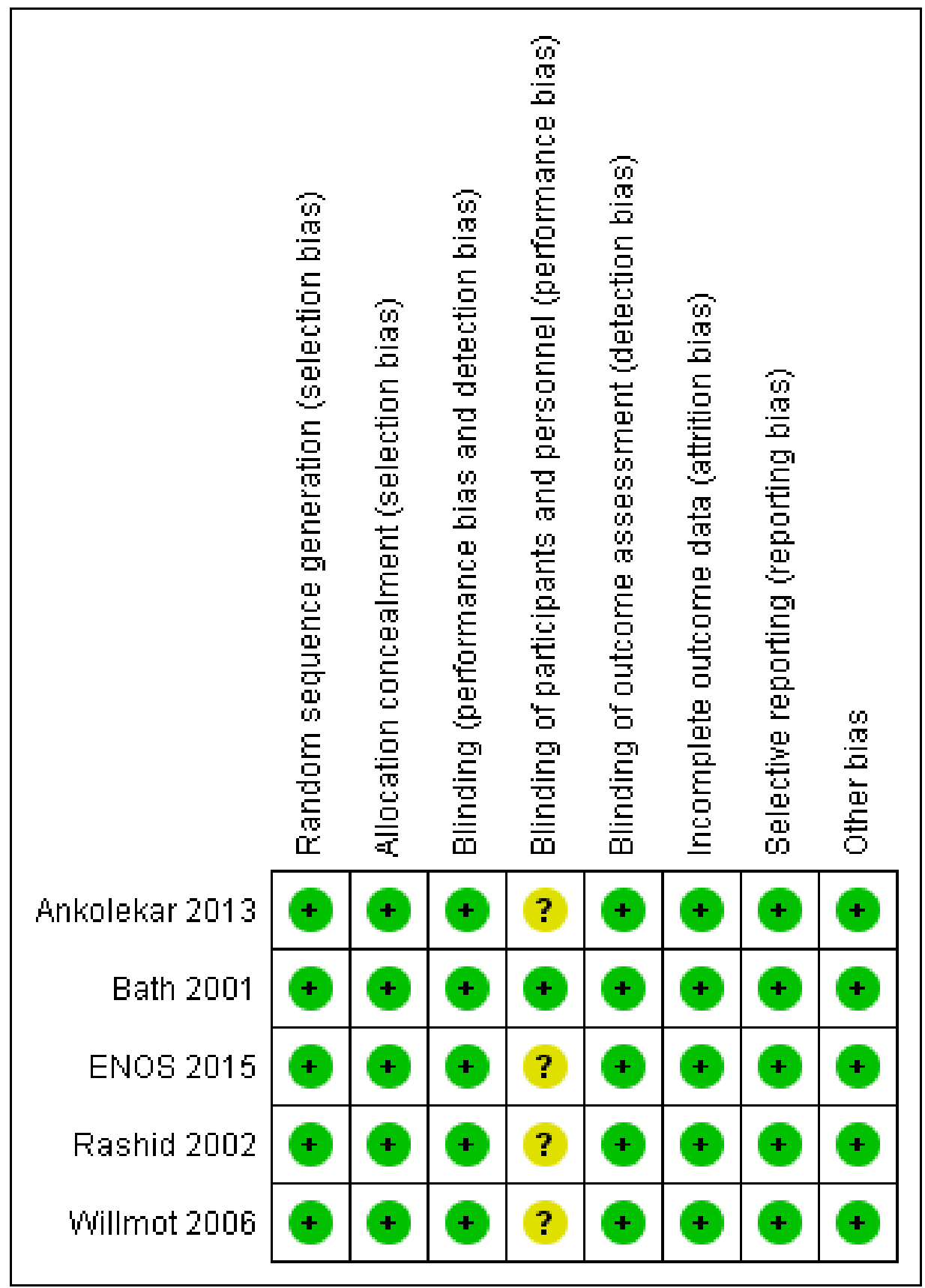

\section{Allocation}

Randomisation can be summarised as follows (Characteristics of included studies).

- Simple randomisation 1:1 (Ankolekar 2013) was deemed at low risk of selection bias and ensured allocation concealment.

- Computer minimisation 1:1 (Bath 2001; ENOS 2015; Rashid 2002) were deemed at low risk of selection bias and ensured allocation concealment.

- Computer minimisation 2:1 (Willmot 2006) was deemed at low risk of selection bias and ensured allocation concealment.

\section{Blinding}

Participants and investigators were blinded to treatment as follows.

- Double-blind (participant and investigator): one trial (Bath 2001).

- Single-blind (participant): three trials (Ankolekar 2013; ENOS 2015; Willmot 2006).

- Open-label: one trial (Rashid 2002).

Blinding of participants and personnel (performance bias) were deemed unclear risk for the three single-blind trials (Ankolekar 2013; ENOS 2015; Willmot 2006) and the open-label trial (Rashid 
2002). Blinding of outcome assessment (detection bias) was deemed low risk for all included trials as outcomes were assessed centrally blinded to treatment group.

\section{Incomplete outcome data}

All five included trials were analysed by intention-to-treat with no differences in follow-up rates between treatment groups.

\section{Selective reporting}

The likelihood of reporting bias was demonstrated using funnel plots (Figure 4; Figure 5) and was not evident in any of the included trials. Figure 4 assessed the primary outcome (mRS end-of-trial) across the included studies, whilst Figure 5 assessed the first BP measurement after treatment; this was included because it was the primary outcome in the four phase II trials.

Figure 4. Funnel plot of comparison: Glyceryl trinitrate (GTN) compared with no GTN for acute stroke, Outcome: 1.1 Death or dependency (mRS>2), end of trial.

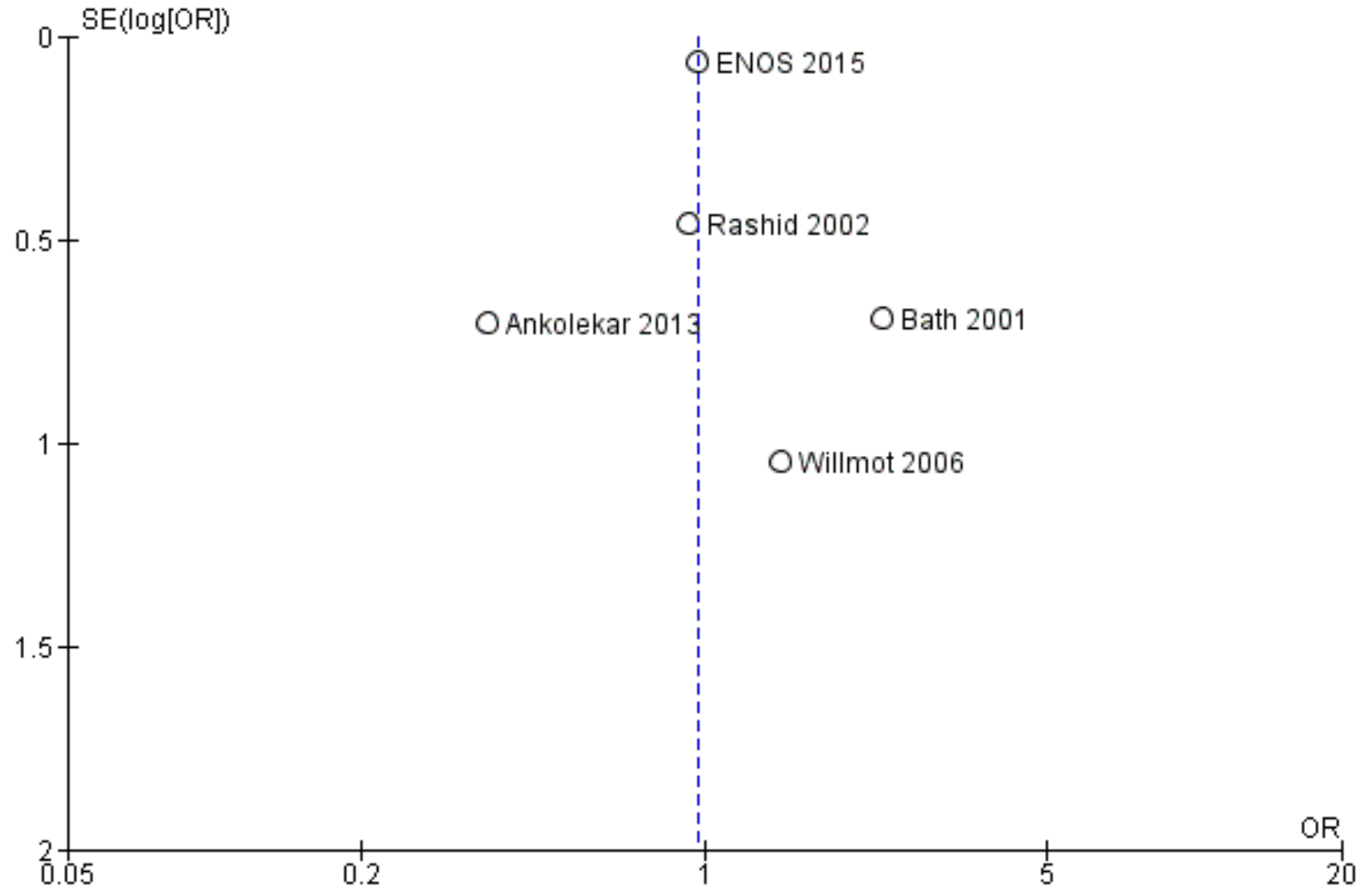


Figure 5. Funnel plot of comparison: Glyceryl trinitrate (GTN) compared with no GTN for acute stroke, outcome: 1.81 Systolic BP, first treatment measurement.

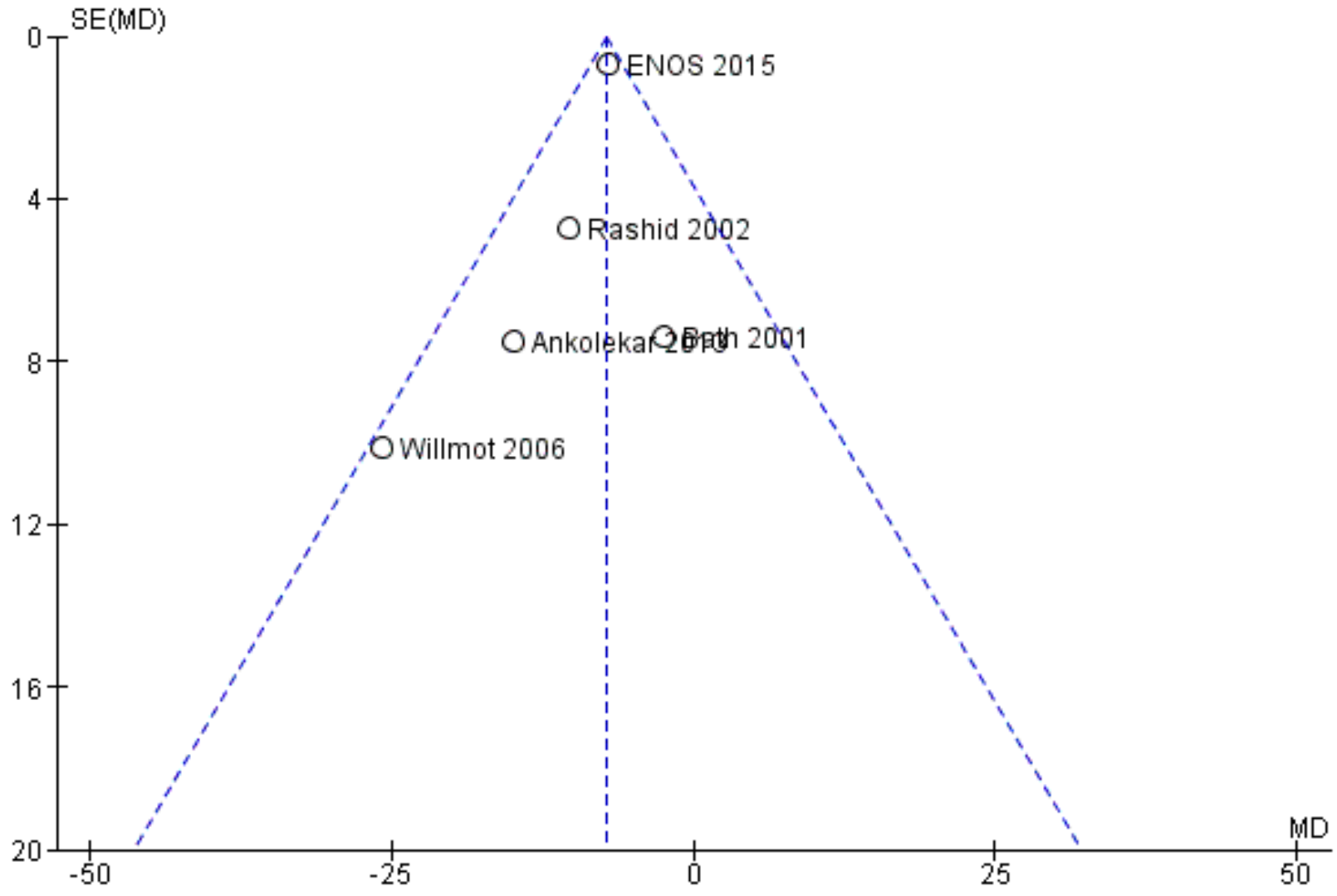

\section{Other potential sources of bias}

We did not identify any other potential sources of bias that might have impacted upon the validity of the included studies.

\section{Effects of interventions}

See: Summary of findings for the main comparison Glyceryl trinitrate (GTN) compared with no GTN for acute stroke

\section{Death or dependency, end of trial}

Death or dependency was assessed as mRS $>2$ at day 90 in all five included trials totaling 4195 participants (Summary of findings for the main comparison; Analysis 1.1). There was no significant difference between GTN and control (OR $0.97,95 \% \mathrm{Cl} 0.86$ to 1.10 ), and no evidence of heterogeneity $(12=0 \%)$. When assessed as continuous data to compare mean mRS, there was no significant difference between GTN and control (MD $-0.08,95 \% \mathrm{Cl}-0.52$ to 0.36 , $12=47 \%$, Analysis 1.5).

\section{Stroke type}

There was no differential effect by stroke type (Analysis 1.2; Analysis 1.6).

\section{Time to randomisation}

Those participants randomised to GTN within six hours of stroke onset (two trials, 312 participants) had a tendency toward less death and dependency (OR $0.65,95 \% \mathrm{Cl} 0.41$ to $1.02 ; \mathrm{P}=0.06 ; \mathrm{I}^{2}$
$=0 \%$ ). Randomisation at more than six hours after ictus did not influence the primary outcome and overall subgroup differences were nonsignificant ( $P=0.28$, Analysis 1.3 ). In the sensitivity analysis, mean $\mathrm{mRS}$ was lower in those randomised to GTN within six hours of onset as compared with control participants (MD -0.79, $95 \% \mathrm{Cl}-1.35$ to $-0.23 ; \mathrm{P}=0.005$ ); an effect not seen in any other time period from randomisation although the interaction between time and $\mathrm{mRS}$ was significant $(\mathrm{P}=0.05$, Analysis 1.7$)$.

\section{Baseline systolic BP}

There was no differential effect by baseline systolic BP (Analysis 1.4; Analysis 1.8).

\section{Death, end of treatment and end of trial}

There was no significant treatment effect of GTN compared with control on death, whether measured early (Analysis 1.9) or end of trial (Analysis 1.13; 4197 participants; Summary of findings for the main comparison). No significant differences were noted in any subgroups for death at end of treatment (Analysis 1.10; Analysis 1.11; Analysis 1.12), whilst death at end of trial was reduced in those randomised to GTN within six hours of stroke onset (OR 0.30, 95\% $\mathrm{Cl} 0.15$ to $0.60 ; \mathrm{P}=0.0006 ; \mathrm{I}^{2}=0 \%$; Analysis 1.15 ), with significant interaction between time and death $(P=0.01)$.

\section{Neurological deterioration, end of treatment}

No significant difference was noted in early neurological deterioration between treatment and control (Analysis 1.17) in 
the four studies with data (4158 participants). Stroke type did not change the neutral effect seen overall (Analysis 1.18). Those randomised between 24 and 36 hours to GTN in one study (1218 participants; two studies were not estimable due to no events) had a higher likelihood of neurological deterioration than control participants (OR 2.00, 95\% $\mathrm{Cl} 1.19$ to $3.35 ; \mathrm{P}=0.009$ ). The other time groups revealed no difference between GTN and control (Analysis 1.19). Participants randomised to GTN with a baseline systolic BP of $<160 \mathrm{mmHg}$ (1688 participants) or 180 to $200 \mathrm{mmHg}$ in two studies (743 participants; two studies were not estimable due to no events) were more likely to have neurological deterioration at end of treatment than controls (OR $1.62,95 \% \mathrm{Cl} 1.05$ to $2.50, \mathrm{P}=0.03$ and $\mathrm{OR} 1.81,95 \% \mathrm{Cl} 1.05$ to $3.12, \mathrm{P}=0.03$, respectively; Analysis 1.20 ).

\section{NIHSS, end of treatment}

NIHSS was calculated using the SSS available from four trials (4137 participants). There was no significant difference between treatment and control (Analysis 1.21). Stroke type and baseline systolic BP had no influence on the neutral effect seen overall (Analysis 1.22; Analysis 1.24). Participants randomised to GTN within six hours of stroke onset had lower NIHSS scores at end of treatment compared with control (MD $-2.07,95 \% \mathrm{Cl}-3.81$ to -0.34 , $\mathrm{P}=0.02$ ), with no heterogeneity seen between the two trials, and significant interaction between time and NIHSS ( $P=0.03$, Analysis 1.23).

\section{Disability (Barthel Index), end of trial}

Disability data in the form of BI was available for all five studies (4153 participants) with no significant difference detected between GTN and control (Analysis 1.25). Those randomised to GTN within six hours of stroke ictus ( 2 trials, 312 participants) had improved disability scores compared with control participants (MD 14.57, $95 \% \mathrm{Cl} 5.95$ to $23.19, \mathrm{P}=0.0009$ ), with no heterogeneity seen between the studies, and significant interaction between time and $\mathrm{BI}(\mathrm{P}=0.03$, Analysis 1.27). Baseline systolic BP and stroke type subgroups had no associations of note for this outcome (Analysis 1.26; Analysis 1.28).

\section{Mood (Zung), end of trial}

Mood was assessed in three studies (3312 participants) using the Zung depression scale (ZDS). No significant difference was seen between GTN and control (Analysis 1.29). Improved mood scores were seen in those randomised to GTN within six hours of the index event compared with control participants (MD - $11.12,95 \% \mathrm{Cl}-17.35$ to $-4.90, P=0.0005)$ with no heterogeneity seen between the two studies (268 participants), and significant interaction between time and ZDS ( $P=0.007$, Analysis 1.31). Stroke type and baseline systolic BP had no associations of note for this outcome (Analysis 1.30; Analysis 1.32).

\section{Quality of life, end of trial}

Two measures of quality of life were assessed: the EQ-5D was transformed into a health utility status from data available in four studies (4088 participants); and the EQ-VAS from four studies (3575 participants). There was no significant difference between treatment and control for either measure (Analysis 1.33; Analysis 1.37). Whilst the subgroups stroke type and baseline systolic BP had no impact on the neutral effect seen overall, early treatment with GTN within six hours of onset was associated with improved quality of life at day 90 compared with those randomised to control (EQ-5D
(2 trials, 312 participants) MD $0.11,95 \% \mathrm{Cl} 0.02$ to $0.20, \mathrm{P}=0.02$, with minimal heterogeneity $(12=3 \%$; Analysis 1.35$)$; and EQ-VAS ( 2 trials, 295 participants) MD $9.96,95 \% \mathrm{Cl} 2.49$ to $17.43, \mathrm{P}=0.009$ with no heterogeneity (Analysis 1.39)). Across time to randomisation, there was a significant interaction with EQ-VAS $(P=0.04)$, but not EQ-5D $(P=0.10)$.

\section{Cognition, end of trial}

Three measures of cognition were assessed: three studies had tMMSE data (2078 participants, in two studies t-MMSE was derived from MMSE); one study also used TICS and animal naming (ENOS 2015). Overall, there was no significant difference between GTN and control (Analysis 1.41; Analysis 1.45; Analysis 1.49). Stroke type and baseline systolic BP did not influence this finding (Analysis 1.42; Analysis 1.44; Analysis 1.46; Analysis 1.48; Analysis 1.50; Analysis 1.52). Improved cognitive scores were seen across all three measures in those randomised to GTN within six hours of onset (t-MMSE: MD 3.61, 95\% Cl 1.68 to 5.55, $\mathrm{P}=0.0002$ (2 trials, 219 participants, interaction $\mathrm{P}=0.003$; Analysis 1.43); TICS: MD 5.59, $95 \% \mathrm{Cl} 2.63$ to $8.55, \mathrm{P}=0.0002$ (1 trial, 182 participants, interaction $\mathrm{P}$ $=0.002$; Analysis 1.47); and animal naming: MD 2.94, $95 \% \mathrm{Cl} 0.88$ to $5.00, \mathrm{P}=0.005$ ( 1 trial, 192 participants, interaction $\mathrm{P}=0.04$; Analysis $1.51))$.

\section{Physiotherapy, occupational therapy, and speech and language therapy}

Data on whether individuals received physiotherapy, occupational therapy or speech and language therapy during their admission were available from three studies (4042 participants). There was no difference between treatment groups in the rates of therapy required (Analysis 1.53; Analysis 1.57; Analysis 1.61). Rates of occupational therapy were lower, with borderline significance, in those randomised to GTN with baseline systolic BP level of 180.1 to $200 \mathrm{mmHg}$ compared with control participants (OR $0.74,95 \%$ $\mathrm{Cl} 0.54$ to $1.00, \mathrm{P}=0.05$ ), with no heterogeneity seen between the three studies (730 participants), and higher in those randomised to GTN with baseline systolic BP $>200 \mathrm{mmHg}$ compared with controls (OR $2.11,95 \% \mathrm{Cl} 1.25$ to $3.54, \mathrm{P}=0.005$ ), with no heterogeneity between the two studies (255 participants; Analysis 1.60). No other associations regarding baseline systolic BP were noted for rates of either physiotherapy (Analysis 1.56) or speech and language therapy (Analysis 1.64). Neither time to randomisation nor stroke type had any effect on therapy rates between treatment and control.

\section{Feeding route (non-oral feeding at day 7 )}

Feeding route was recorded in three trials (4009 participants) and assessed as non-oral feeding at day seven. Overall, there was no difference between GTN versus no GTN regarding rates of nonoral feeding at day seven (Analysis 1.65). Early treatment with GTN within six hours of onset was associated with a nonsignificant tendency towards less non-oral feeding (OR $0.59,95 \% \mathrm{Cl} 0.32$ to $1.08, P=0.09$ ), with no heterogeneity seen between the two studies (301 participants; Analysis 1.67). No associations of note were seen regarding other factors (time groups from randomisation, stroke type or baseline systolic BP (Analysis 1.66; Analysis 1.68)).

\section{Length of stay}

The length of hospital stay relating to the index randomising event was assessed in four studies (4078 participants), with no significant 
treatment effect noted (Analysis 1.69). No subgroup effects were noted (Analysis 1.70; Analysis 1.71; Analysis 1.72).

\section{Headache on treatment}

Headache on treatment was more common in people randomised to GTN than to control (OR 2.37, 95\% Cl 1.55 to $3.62 ; 4186$ participants), with no significant heterogeneity seen (Analysis 1.73; Summary of findings for the main comparison). GTN led to increased reporting of headache on treatment in both ischaemic stroke (OR 2.39, $95 \% \mathrm{Cl} 1.59$ to $3.61, \mathrm{P}<0.0001 ; 3409$ participants; $\mathrm{I}^{2}=4 \%$ ) and ICH (OR 1.91, 95\% Cl 1.24 to 2.93, $\mathrm{P}=0.003$; 639 participants; $12=0 \%$ ) compared with control (Analysis 1.74). Headache was more common in participants randomised to GTN than controls for all time periods of randomisation (Analysis 1.75) and all baseline systolic BP subgroups except $>200 \mathrm{mmHg}$, which was neutral (Analysis 1.76).

\section{Treatment stopped early}

There was no significant difference in the rate of treatment being stopped early between those randomised to GTN or control (4193 participants), although there was significant heterogeneity between trials ( $12=88 \%$; Analysis 1.77$)$. Treatment was more likely to be stopped in those randomised to GTN after six, and before 36, hours but these groups were dominated by ENOS 2015 (Analysis 1.79). Stroke type and baseline systolic BP did not alter the overall neutral effect seen.

\section{Haemodynamics}

Haemodynamics are the first measurements on treatment (4197 participants; Summary of findings for the main comparison; highquality evidence). BP ( $\mathrm{mmHg}$ ) was significantly lowered in those randomised to GTN compared with control (systolic BP: MD -7.21, $95 \% \mathrm{Cl}-8.58$ to -5.85 , Analysis 1.81; diastolic BP: MD $-3.31,95 \% \mathrm{Cl}$ -4.18 to -2.45 , Analysis 1.84 ), whilst heart rate (beats per minute) was significantly increased (MD 2.02, $95 \% \mathrm{Cl} 1.13$ to 2.91, Analysis 1.87). Of note, for heart rate there was significant heterogeneity (12 $=61 \%)$ between trials. Regardless of stroke type, BP was significantly lowered by GTN compared with control, and heart rate was increased (Analysis 1.82; Analysis 1.85; Analysis 1.88). BP was significantly lowered in those randomised to GTN compared with control in all time to randomisation groups (Analysis 1.83; Analysis 1.86), whilst heart rate was significantly increased in those randomised to GTN after 24, and before 36, hours (MD 3.44, 95\% Cl 1.79 to $5.09 ; 1218$ participants; $\left.\left.\right|^{2}=32 \%\right)$, with nonsignificant results seen in other time groups (Analysis 1.89).

\section{DISCUSSION}

\section{Summary of main results}

Five trials involving 4197 participants assessed transdermal GTN in acute stroke. Overall, GTN did not significantly influence clinical outcomes including death or disability, death, neurological deterioration, severity, mood, quality of life, cognition, length of hospital stay, therapy requirements, or feeding route.

Subgroup analyses showed that participants randomised to GTN with baseline systolic BP $<160$ or 180 to $200 \mathrm{mmHg}$ had increased rates of neurological deterioration compared with controls. Conversely, receiving GTN with a baseline systolic BP 180 to 200 $\mathrm{mmHg}$ was associated with lower rates of occupational therapy but higher rates were seen with a baseline systolic BP $>200$ $\mathrm{mmHg}$. There were no consistent effects across outcomes regarding baseline systolic BP. Participants randomised to GTN within six hours of symptom onset had nonsignificant reductions in the rates of death or dependency (mRS > 2) and non-oral feeding, and significant improvements in NIHSS at end of treatment, and death or dependency (mean mRS), death, disability, mood, quality of life, and cognition at end of trial. Although participants randomised to GTN between 24 and 36 hours after stroke onset had an increased chance of neurological deterioration, no significant findings were noted in any other clinical outcomes for this time period. Some of the heterogeneity seen between the trials for several outcomes may relate to the differing times from stroke onset to randomisation, which ranged from within four hours of onset up to 168 hours from onset.

In respect of haemodynamics, BP was significantly lowered by GTN as compared with control regardless of stroke type and time to randomisation, whilst heart rate was significantly increased overall, regardless of stroke type, and in those randomised between 24 and 36 hours after stroke onset. Headache, a recognised side effect of GTN, was more commonly seen in those randomised to GTN overall, in both stroke types, at all times of randomisation and in all but those with baseline systolic BP > $200 \mathrm{mmHg}$.

Of note, there was no significant difference in the rate of treatment being stopped early between GTN and control but there was significant heterogeneity between the trials. Those who received GTN between six and 36 hours of stroke onset were more likely to stop treatment early; a finding driven by ENOS (ENOS 2015).

\section{Overall completeness and applicability of evidence}

This review includes all identified trials of NO donors in people with recent stroke. All five trials studied transdermal GTN and no RCTs assessing other NO donors, L-arginine or nitric oxide synthase inhibitors have been completed. The results from trials assessing GTN should not be extrapolated to other NO donors, L-arginine or nitric oxide synthase inhibitors. With 4197 participants across five trials, this review has substantial external validity and is able to comment on the safety and efficacy of GTN in acute stroke. Overall, GTN was safe, lowered BP and increased heart rate, but had no beneficial effect on primary and secondary clinical outcomes.

The potential benefit of GTN seen in participants randomised within six hours of onset may represent chance, but there are several explanations to suggest that the association could be real.

1. The beneficial effects seen were across multiple outcomes including death, dependency (mRS), disability (BI), mood (ZDS), NIHSS, quality of life (EQ-5D health utility status and EQ-VAS) and cognition (t-MMSE, TICS, animal naming).

2. The effects were seen in two separate trials (Ankolekar 2013; ENOS 2015).

3. The effects were seen in a population of over 300 participants. This group is equivalent in size to each of the parts of the positive NINDS trials of intravenous alteplase (NINDS 1995) and recent trials of mechanical thrombectomy (Goyal 2016).

4. The time-dependent effect of NO donors has been demonstrated in a meta-analysis of pre-clinical studies in which early treatment within 60 minutes of ischaemia was associated with positive outcomes as compared with neutral outcomes 
in those studies assessing treatment up to 48 hours following induction of ischaemic stroke (Willmot 2005).

Hyperacute administration of NO donors, such as GTN, has several potential mechanisms of action alluded to in the background of this review.

1. NO levels are low in acute stroke and replacing this deficiency may be beneficial.

2. NO donors lower BP, pulse pressure and peak systolic BP, and improve arterial compliance. Lowering BP acutely may reduce early recurrence following ischaemic stroke, and haematoma expansion in ICH (Anderson 2013).

3. NO dilates cerebral arteries thereby increasing perilesional perfusion through the 'front door' without resultant cerebral steal (Willmot 2006).

4. NO is a potent vasodilator of pial arteries leading to 'back-door' collateral reperfusion (Morikawa 1992b).

5. NO donors are neuroprotective when administered early after preclinical ischaemic stroke (Willmot 2005).

6. NO donors might augment the effects of established interventions such as intravenous alteplase, both through preparing patients for treatment by lowering BP, and potentially by increasing access of lytics to occluding clot.

\section{Quality of the evidence}

This review has several strengths.

1. The study cohort was large, involving more than 4000 participants.

2. Individual patient data were used from all identified controlled trials of NO donors, facilitating subgroup analyses.

3. Differing participant characteristics between trials broadened external validity.

4. The trials examined different time-windows after stroke onset including ultra-acute/pre-hospital (Ankolekar 2013), hyperacute ( $<6$ hours) (ENOS 2015), acute ( $<48$ hours) (ENOS 2015), and sub-acute (< 168 hours) (Bath 2001; Rashid 2002; Willmot 2006).

5. Safety and efficacy were assessed across a multitude of outcomes encompassing multiple clinical domains; similar results across outcome domains and trials suggest intra- and inter-trial consistency.

There are also several limitations of this review.

1. GTN was the only NO donor assessed in the included RCTs and therefore the results cannot be extrapolated to other NO donors, for which there is no RCT-based evidence.

2. ENOS 2015 accounted for $95.6 \%$ of all participants included in this review, and therefore dominated the data and subsequent analyses.

3. All these data were reported by the same research group and therefore the results need to be validated and extended by other research groups.

4. Only one of the included studies was double-blind (Bath 2001), with the remainder being single-blind (Ankolekar 2013; ENOS 2015; Willmot 2006) or open-label (Rashid 2002). Further, headache, a common side effect of GTN, may have unblinded some participants. In addition, despite all end-of-trial outcome measures being performed by assessors blinded to treatment in the included studies, observer bias cannot be excluded.

5. The results relating to ultra-acute and hyper-acute treatment involved a relatively small number of participants (Ankolekar 2013; ENOS 2015); these findings should be considered provisional and require formal testing.

6. This review contains analyses involving a variety of outcomes assessed in several subgroups. Such multiple testing can lead to spurious results and it is possible that some findings may simply reflect chance, e.g. increased neurological deterioration in certain BP subgroups (in the absence of a trend across BP, or a negative effect on the NIHSS), or variation in occupational therapy utilisation in BP subgroups.

In summary, the overall quality of the evidence as assessed by GRADE criteria was high, due to the aforementioned strengths of the included studies.

\section{Potential biases in the review process}

This review was compiled following an extensive literature search, without language restrictions, by both the review authors and Cochrane Stroke Group. The resultant risk for publication bias is therefore low. However, all the included trials were from the same research group - of which the authors are members - which may have potentially introduced bias in the review process, e.g. in choice of outcomes and subgroups. Nevertheless, all outcomes reported in the included trials were summarised here (including mRS, BI, EQ-5D, EQ-VAS, t-MMSE, TICS-M, animal naming, ZDS, NIHSS, death), and subgroups (time, stroke type, blood pressure) were used as prespecified in the ENOS trial (ENOS 2015).

\section{Agreements and disagreements with other studies or reviews}

A recently published systematic review and individual patient data meta-analysis assessed the same five trials of transdermal GTN under the auspices of the Blood pressure in Acute Stroke Collaboration (BASC 2016). Both unadjusted and adjusted analyses were performed including a predefined subgroup analysis by time to randomisation. In this regard, the results and conclusions of both reviews were similar showing that GTN is safe though ineffective overall, but may improve outcome in a time-dependent manner if given within six hours of stroke onset.

\section{AUTHORS' CONCLUSIONS}

\section{Implications for practice}

There is currently insufficient evidence to determine the efficacy of NO donors, L-arginine, or nitric oxide synthase inhibitors in acute stroke, with only RCT evidence available for the NO donor, GTN. In people with acute stroke, transdermal GTN reduces blood pressure, increases heart rate and headache, but does not alter outcome. When administered within six hours, GTN may improve clinical outcomes, a finding that requires confirmation in an independent trial (e.g. RIGHT-2 2015).

\section{Implications for research}

Large phase III randomised trials are required to assess the administration of NO donors in ultra-acute and hyper-acute strokes. 
- The safety and efficacy of NO donors other than GTN.

- The safety and efficacy of GTN administered in the ultra-acute phase/prehospital environment (e.g. RIGHT-2 2015).

- The effect of GTN on long-term functional outcome and death, i.e. beyond 90 days (e.g. RIGHT-2 2015).

- Mechanisms by which GTN might work, e.g. potentially through reducing haematoma expansion in $\mathrm{ICH}$, and improving collateral supply in ischaemic stroke (e.g. RIGHT-2 2015).

- The health economics of GTN (although the low cost of treatment, i.e. $<£ 5$ per patient, means that GTN will dominate if efficacy is seen for $\mathrm{mRS}$ ).

- Whether there are particular subgroups who benefit, or do not benefit, from GTN.
- Whether GTN acts as adjunctive therapy to intravenous thrombolysis in ischaemic stroke.

- Whether GTN acts as adjunctive therapy to mechanical thrombectomy in ischaemic stroke.

- Whether GTN reduces the need for hospital-based therapies such as mechanical thrombectomy, hemicraniectomy, need for rehabilitation therapy.

- Whether low and middle income countries can utilise GTN in the hyperacute period.

\section{ACK N O WLEDGEMENTS}

We are grateful to the Editorial Board of the Cochrane Stroke Group, external peer reviewer, and consumer reviewer (Katarina Paunovic) for making constructive comments on this review. No pharmaceutical company was involved in this review. 


\section{RE F E R E N C E S}

\section{References to studies included in this review}

Ankolekar 2013 \{published and unpublished data\}

* Ankolekar S, Fuller M, Cross I, Renton C, Cox P, Sprigg N, et al. Feasibility of an ambulance-based stroke trial, and safety of glyceryl trinitrate in ultra-acute stroke: the Rapid Intervention with Glyceryl Trinitrate in Hypertensive Stroke Trial (RIGHT). Stroke 2013;44:3120-8. [ISRCTN66434824]

Ankolekar S, Parry R, Sprigg N, Siriwardena AN, Bath PMW. Views of paramedics on their role in an out-of-hospital ambulance-based trial in ultra-acute stroke: qualitative data from the Rapid Intervention with Glyceryl trinitrate in Hypertensive stroke Trial (RIGHT). Annals of Emergency Medicine 2014;64(6):640-8.

Ankolekar S, Sare G, Geeganage C, Fuller M, Stokes L, Sprigg N, et al. Determining the feasibility of ambulance-based randomised controlled trials in patients with ultra-acute stroke: study protocol for the "Rapid Intervention with GTN in Hypertensive Stroke Trial" (RIGHT). Stroke Research and Treatment 2012;2012:385753. [ISRCTN66434824]

Bath 2001 \{published and unpublished data\}

Bath PMW, Pathansali R, Iddenden R, Bath FJ. The effect of nitric oxide, given as transdermal glyceryl trinitrate, on blood pressure in acute stroke. Cerebrovascular Diseases 1999;9 Suppl 1:101.

* Bath PMW, Pathansali R, Iddenden R, Bath FJ. The effect of transdermal glyceryl trinitrate, a nitric oxide donor, on blood pressure and platelet function in acute stroke. Cerebrovascular Diseases 2001;11:265-72.

\section{ENOS 2015 \{published and unpublished data\}}

Bath PMW, Houlton A, Woodhouse L, Sprigg N, Wardlaw J, Pocock S, the ENOS Trialists. Statistical analysis plan for the 'Efficacy of Nitric Oxide in Stroke' (ENOS) trial. International Journal of Stroke 2014;9:372-4.

ENOS Investigators. Baseline characteristics of the 4011 patients recruited into the 'Efficacy of Nitric Oxide in Stroke' (ENOS) trial. International Journal of Stroke 2014;9:711-20.

* The ENOS Trial Investigators. Efficacy of nitric oxide, with or without continuing antihypertensive treatment, for management of high blood pressure in acute stroke (ENOS): a partial-factorial randomised controlled trial. Lancet 2015;385:617-28.

The ENOS Trial Investigators. Glyceryl trinitrate vs control, and continuing vs stopping temporarily prior antihypertensive therapy, in acute stroke: rationale and design of the efficacy of nitric oxide in stroke (ENOS) trial. International Journal of Stroke 2006;1:245-9. [ISRCTN99414122]

\section{Rashid 2002 \{published and unpublished data\}}

Rashid PA, Leonardi-Bee JA, Weaver CS, Bath FJ, Bath PM. The effect of transdermal glyceryl trinitrate, a nitric oxide donor, on blood pressure and middle cerebral artery blood velocity in acute stroke. Stroke 2002;33:383.
* Rashid PA, Weaver C, Leonardi-Bee JA, Bath FJ, Fletcher S, Bath PMW. The effects of transdermal glyceryl trinitrate, a nitric oxide donor, on blood pressure, cerebral and cardiac hemodynamics, and plasma nitric oxide levels in acute stroke. Journal of Stroke and Cerebrovascular Diseases 2003;12(3):143-51.

Willmot 2006 \{published and unpublished data\}

Willmot M, Ghadami A, Whysall B, Clarke W, Wardlaw J, Bath PMW. Transdermal glyceryl trinitrate lowers blood pressure and maintains cerebral blood flow in recent stroke. Hypertension 2006;47:1209-15.

\section{References to studies excluded from this review}

Butterworth 1998 \{published data only\}

Butterworth RJ, Cluckie A, Jackson SHD, Buxton-Thomas M, Bath PMW. Sodium nitroprusside, a spontaneous nitric oxide donor in acute ischaemic stroke. Cerebrovascular Diseases 1998;8:158-65.

\section{El Mously 2014 \{published data only\}}

El Mously SM, El Bialy RB, El Khayat ZK, Masoud HM, El Mously LM. Assessment of S100B biomarker in hypertensive patients with acute ischemic stroke treated with glyceryl trinitrate. Cerebrovascular Diseases 2014;37 Suppl 1:418.

\section{El-Zammer 2012 \{published data only\}}

El-Zammer ZM, Latorre JG, Wang D, Satyan S, Elnour E, Kamel A, et al. Intra-arterial vasodilator use during endovascular therapy for acute ischaemic stroke might improve reperfusion rate. Annals of the New York Academy of Sciences 2012;1268:134-40.

FAST-BP 2013 \{published data only\}

NCT01811693. Field Administration of Stroke Therapy - Blood Pressure lowering (FAST-BP). clinicaltrials.gov/ct2/show/ NCT01811693?term=NCT01811693\&rank=1 (accessed prior to 6 April 2017). [NCT01811693]

\section{Flinders 2014 \{published data only\}}

Flinders A, Sanossian N, Kim MA, Liebeskind D, Eckstein M, Stratton S, et al. Antihypertensive utilization in hyperacute intracerebral haemorrhage presenting to the emergency room. Stroke 2014;45 Suppl 1:A199.

\section{Kate 2015 \{published data only\}}

Kate M, Asdaghi N, Gioia L, Buck B, Jeerakathil T, Shuaib A, et al. Blood pressure reduction in acute ischaemic stroke does not affect ischemic core tissue perfusion.. International Journal of Stroke 2015;10 Suppl S2:226.

\section{Kerr 2000 \{published data only\}}

Kerr S. The effect of nitric oxide donation on regional cerebral blood flow and metabolism in acute ischaemic stroke. National Research Register: sites.google.com/a/york.ac.uk/ yhectrialsregisters/home/researchregisters/uk-nationalresearch-register-1 (accessed prior to 6 April 2017). 
MAPAS 2009 \{published data only\}

NCT00848770. Manipulation of Arterial Pressure in Acute ischemic Stroke (MAPAS). clinicaltrials.gov/ct2/show/ NCT00848770?term $=$ NCT00848770\&rank $=1$ (accessed prior to 6 April 2017). [NCT00848770]

Nakamura 2010 \{published data only\}

Nakamura T, Tsutsumi Y, Shimizu Y, Uchiyama S. Reninangiotension system blockade safely reduces blood pressure in patients with minor ischemic stroke during the acute phase. Journal of Stroke and Cerebrovascular Diseases 2010;19(6):435-40.

\section{PATICH 2014 \{published data only\}}

Zheng J, Lin S, Li H, Ma J, Fang Y, Ma L, et al. Perioperative Antihypertensive Treatment in patients of spontaneous IntraCerebral Haemorrhage (PATICH): a clinical trial protocol. Contemporary Clinical Trials 2014;39(1):9-13.

\section{PATIS 2009 \{published data only\}}

NCT02327793. Perfusion and Antihypertensive Therapy in Acute Ischemic Stroke (PATIS). clinicaltrials.gov/ct2/show/ NCT02327793?term=NCT02327793\&rank=1 (accessed prior to 6 Apri 2017). [NCT02327793]

\section{Roitberg 2008 \{published data only\}}

Roitberg BZ, Hardman J, Urbaniak K, Merchant A, Mangubat EZ, Alaraj $A$, et al. Prospective randomised comparison of safety and efficacy of nicardipine and nitroprusside drip for control of hypertension in the neurosurgical intensive care unit. Neurosurgery 2008;63(1):115-20.

\section{Sakamoto 2015 \{published data only\}}

Sakamoto Y, Koga M, Todo K, Okuda S, Okada Y, Kimura K, et al. Relative systolic blood pressure reduction and clinical outcomes in hyperacute intracerebral haemorrhage: the SAMURAI-ICH observational study. Journal of Hypertension 2015;33(5):1069-73.

\section{Sanossian 2012 \{published data only\}}

Sanossian N, Flinders A, Olivas E, Starkman S, Liebeskind D, Eckstein $\mathrm{M}$, et al. Door to blood pressure goal achievement in community management of hyperacute intracerebral haemorrhage. Annals of Emergency Medicine 2012;60:S56.

\section{Suri 2009 \{published data only\}}

Suri MF, Vazquez G, Ezzeddine MA, Qureshi Al. A multicenter comparison of outcomes associated with intravenous nitroprusside and nicardipine treatment among patients with intracerebral haemorrhage. Neurocritical Care 2009;11(1):50-5.

\section{Xu 2007 \{published data only\}}

Xu D, Liu J, Wang A, Zhao C. Nitrogen monoxide vector of ultrasonic atomizing inhalation improves vertebro-basilar artery insufficiency: hemodynamic changes are detected by transcranial Doppler test. Neural Regeneration Research 2007;2(8):506-9.

\section{References to ongoing studies}

RIGHT-2 2015 \{published data only\}

ISRCTN26986053. Rapid Intervention with Glyceryl trinitrate in Hypertensive stroke Trial-2. www.isrctn.com/ISRCTN26986053 (accessed prior to 6 April 2017). [ISRCTN26986053]

\section{Additional references}

\section{Anderson 2013}

Anderson CS, Heeley E, Huang Y, Wang J, Stapf C, Delcourt C, INTERACT2 Investigators. Rapid blood-pressure lowering in patients with acute intracerebral hemorrhage. New England Journal of Medicine 2013;368(25):2355-65.

\section{Atochin 2007}

Atochin DN, Wang A, Liu VW, Critchlow JD, Dantas AP, LooftWilson R, et al. The phosphorylation state of eNOS modulates vascular reactivity and outcome of cerebral ischemia in vivo. Journal of Clinical Investigation 2007;117:1961-7.

\section{Atochin 2010}

Atochin DN, Yuzawa I, Li Q, Rauwerdink KM, Malhotra R, Chang J, et al. Soluble guanylate cyclase alpha1beta1 limits stroke size and attenuates neurological injury. Stroke 2010;41:1815-9.

\section{BASC 2016}

Bath PM, Woodhouse L, Krishnan K, Anderson C, Berge E, Ford GA, Blood pressure in Acute Stroke Collaboration (BASC). Effect of treatment delay, stroke type, and thrombolysis on the effect of glyceryl trinitrate, a nitric oxide donor, on outcome after acute stroke: a systematic review and meta-analysis of individual patient from randomised trials. Stroke Research and Treatment 2016;2016:1-12. [DOI: 10.1155/2016/9706720]

\section{Bath 1991}

Bath PMW, Hassall DG, Gladwin AM, Plamer RMJ, Martin JF. Nitric oxide and prostacyclin. Divergence of inhibitory effects on monocyte chemotaxis and adhesion to endothelium in vitro. Arterisclerosis \& Thrombosis 1991;11:254-60.

\section{Britton 1986}

Britton M, Carlsson A, De Faire U. Blood pressure course in patients with acute stroke and matched controls. Stroke 1986;17(5):861-4.

\section{Cho 1992}

Cho HJ, Xie QW, Calaycay J, Mumford RA, Swiderek KM, Lee TD, et al. Calmodulin is a subunit of nitric oxide synthase from macrophages. Journal of Experimental Medicine 1992;176:599-604.

\section{Corsani 2008}

Corsani L, Bizzoco E, Pedata F, Gianfriddo M, FaussonePellegrini MS, Vannucchi MG. Inducible nitric oxide synthase appears and is co-expressed with the neuronal isoform in interneurons of the rat hippocampus after transient ischemia induced by middle cerebral artery occlusion. Experimental Neurology 2008;211:433-40. 


\section{Cui 2009}

Cui X, Chopp M, Zacharek A, Zhang C, Roberts C, Chen J. Role of endothelial nitric oxide synthase in arteriogenesis after stroke in mice. Neuroscience 2009;159:744-50.

\section{Dawson 1994}

Dawson TM, Snyder SH. Gases as biological messengers: nitric oxide and carbon monoxide in the brain. Journal of Neuroscience 1994;14:5147-59.

\section{DerSimonian 1986}

DerSimonian R, Laird N. Meta-analysis in clinical trials. Controlled Clinical Trials 1986;7:177-88.

\section{Emberson 2014}

Emberson J, Lees KR, Lyden P, Blackwell L, Albers G, Bluhmki E, Stroke Thrombolysis Trialists' Collaborative Group. Effect of treatment delay, age, and stroke severity on the effects of intravenous thrombolysis with alteplase for acute ischaemic stroke: a meta-analysis of individual patient data from randomised trials. Lancet 2014;384(9958):1929-35.

\section{Endres 2004}

Endres M, Laufs U, Liao JK, Moskowitz MA. Targeting eNOS for stroke protection. Trends in Neurosciences 2004;27:283-9.

\section{Fagan 1998}

Fagan SC, Bowes MP, Lyden PD, Zivin JA. Acute hypertension promotes hemorrhagic transformation in a rabbit embolic stroke model: effect of labetalol. Experimental Neurology 1998;150(1):153-8.

\section{Ferlito 1998}

Ferlito S, Gallina M, Pitari GM, Bianchi A. Nitric oxide plasma levels in patients with chronic and acute cerebrovascular disorders. Panminerva Medicine 1998;40:51-4.

\section{Fleming 1991}

Fleming I, Gray GA, Schott C, Stoclet JC. Inducible but not constitutive production of nitric oxide by vascular smooth muscle cells. European Journal of Pharmacology 1991;200:375-6.

\section{Garthwaite 1988}

Garthwaite J, Charles SL, Chess-Williams R. Endothelium derived relaxing factor release on activation of NMDA receptors suggests role as intercellular messenger in the brain. Nature 1988;336:385-8.

\section{Goyal 2016}

Goyal M, Menon BK, Van Zwam WH, Dippel DWJ, Mitchell PJ, Demchuk AM, the HERMES Collaborators. Endovascular thrombectomy after large-vessel ischaemic stroke: a metaanalysis of individual patient data from five randomised trials. Lancet 2016;387(10029):1723-31.

\section{Gray 2009}

Gray LJ, Ali M, Lyden PD, Bath PM, Virtual International Stroke Trials Archive Collaboration. Interconversion of the National Institutes of Health Stroke Scale and Scandinavian Stroke Scale in acute stroke. Journal of Stroke and Cerebrovascular Diseases 2009;18:466-8.

\section{Hara 1996}

Hara H, Huang PL, Panahian N, Fishman MC, Moskowitz MA. Reduced brain edema and infarction volume in mice lacking the neuronal isoform of nitric oxide synthase after transient MCA occlusion. Journal of Cerebral Blood Flow \& Metabolism 1996;16:605-11.

\section{Higgins 2011}

Higgins JPT, Green S (editors). Cochrane Handbook for Systematic Reviews of Interventions Version 5.1.0 (updated March 2011). The Cochrane Collaboration 2011. Available from handbook.cochrane.org.

\section{Huang 1994}

Huang Z, Huang PL, Panahian N, Dalkara T, Fishman MC, Moskowitz MA. Effects of cerebral ischemia in mice deficient in neuronal nitric oxide synthase. Science 1994;265:1883-5.

\section{Huang 1996}

Huang Z, Huang PL, Ma J, Meng W, Ayata C, Fishman MC, et al. Enlarged infarcts in endothelial nitric oxide synthase knockout mice are attenuated by nitro-L-arginine. Journal of Cerebral Blood Flow \& Metabolism 1996;16:981-7.

\section{ladecola 1995}

Iadecola C, Zhang F, Xu X. Inhibition of inducible nitric oxide synthase ameliorates cerebral ischemic damage. American Journal of Physiology 1995;268:R286-92.

\section{ladecola 1997}

ladecola C, Zhang F, Casey R, Nagayama M, Ross ME. Delayed reduction of ischemic brain injury and neurological deficits in mice lacking the inducible nitric oxide synthase gene. Journal of Neuroscience 1997;17:9157-64.

\section{Kader 1993}

Kader A, Frazzini VI, Solomon RA, Trifiletti RR. Nitric oxide production during focal cerebral ischemia in rats. Stroke 1993;24:1709-16.

\section{Knowles 1989}

Knowles RG, Palacios M, Palmer RM, Moncada S. Formation of nitric oxide from L-arginine in the central nervous system: a transduction mechanism for stimulation of the soluble guanylate cyclase. Proceedings of the National Academy of Sciences of the United States of America 1989;86:5159-62.

\section{Lavi 2003}

Lavi S, Egbarya R, Lavi R, Jacob G. Role of nitric oxide in the regulation of cerebral blood flow in humans: chemoregulation versus mechanoregulation. Circulation 2003;107:1901-5.

\section{Leonardi-Bee 2002}

Leonardi-Bee J, Bath PM, Phillips SJ, Sandercock PA, IST Collaborative Group. Blood pressure and clinical outcomes in the International Stroke Trial. Stroke 2002;33(5):1315-20. 


\section{Lo 1996}

Lo EH, Hara H, Rogowska J, Trocha M, Pierce AR, Huang PL, et al. Temporal correlation mapping analysis of the hemodynamic penumbra in mutant mice deficient in endothelial nitric oxide synthase gene expression. Stroke 1996;27:1381-5.

\section{Mackay 2004}

Mackay J, Mensah G. The Atlas of Heart Disease and Stroke. http://www.who.int/cardiovascular_diseases/resources/atlas/ en/ (accessed prior to 6 April 2017).

\section{Malinski 1993}

Malinski T, Bailey F, Zhang ZG, Chopp M. Nitric oxide measured by a porphyrinic microsensor in rat brain after transient middle cerebral artery occlusion. Journal of Cerebral Blood Flow \& Metabolism 1993;13:355-8.

\section{Manzoni 1992}

Manzoni O, Prezeau L, Marin P, Deshager S, Bockaert J, Fagni L. Nitric oxide induced blockade of NMDA receptors. Neuron 1992;8:653-62.

\section{Morikawa 1992a}

Morikawa E, Huang Z, Moskowitz MA. L-arginine decreases infarct size caused by middle cerebral arterial occlusion in SHR. American Journal of Physiology 1992;263:H1632-5.

\section{Morikawa 1992b}

Morikawa E, Rosenblatt S, Moskowitz MA. L-arginine dilates rat pial arterioles by nitric oxide-dependent mechanisms and increases blood flow during focal cerebral ischaemia. British Journal of Pharmacology 1992;107(4):905-7.

\section{Morikawa 1994}

Morikawa E, Moskowitz MA, Huang Z, Yoshida T, Irikura K, Dalkara T. L-arginine infusion promotes nitric oxide-dependent vasodilation, increases regional cerebral blood flow, and reduces infarction volume in the rat. Stroke 1994;25:429-35.

\section{Murad 1987}

Murad F, Waldman S, Molina C, Bennett B, Leitman D. Regulation and role of guanylate cyclase-cyclic GMP in vascular relaxation. Progress in Clinical and Biological Research 1987;249:65-76.

\section{NINDS 1995}

National Institute of Neurological Disorders and Stroke rtPA Stroke Study Group. Tissue plasminogen activator for acute ischemic stroke. New England Journal of Medicine 1995;333(24):1581-7.

\section{Niwa 2001}

Niwa M, Inao S, Takayasu M, Kawai T, Kahita Y, Nihashi T, et al. Time course of expression of three nitric oxide synthase isoforms after transient middle cerebral artery occlusion in rats. Neurologia Medico-Chirurgica 2001;41:63-72.

\section{OAST 2007}

Optimising Analysis of Stroke Trials (OAST) Collaboration. Can we improve the statistical analysis of stroke trials? Statistical re-analysis of functional outcomes in stroke trials. Stroke 2007;38:1911-5.

\section{Oppenheimer 1992}

Oppenheimer S, Hachinski V. Complications of acute stroke. Lancet 1992;339(8795):721-4.

\section{Owens 2011}

Owens WB. Blood pressure control in acute cerebrovascular disease. Journal of Clinical Hypertension 2011;13(3):205-11.

\section{Palmer 1987}

Palmer RMJ, Ferrige AG, Moncada S. Nitric oxide release accounts for the biological activity of endothelium derived relaxing factor. Nature 1987;327:524-6.

\section{Palmer 1988}

Palmer RMJ, Ashton DS, Moncada S. Vascular endothelial cells synthesise nitric oxide from L-arginine. Nature 1988;333:664-6.

\section{Qureshi 2008}

Qureshi Al. Acute hypertensive response in patients with stroke - pathophysiology and management. Circulation 2008;118(2):176-87.

\section{Radomski 1987a}

Radomski MW, Palmer RMJ, Moncada S. Endogenous nitric oxide inhibits human platelet adhesion to vascular endothelium. Lancet 1987;ii:1057-8.

\section{Radomski 1987b}

Radomski MW, Palmer RMJ, Moncada S. The anti-aggregating properties of vascular endothelium: interactions between prostacyclin and nitric oxide. British Journal of Pharmacology 1987;92:639-46.

\section{Rashid 2003}

Rashid PA, Whitehurst A, Lawson N, Bath PMW. Plasma nitric oxide (nitrate/nitrite) levels in acute stroke and their relationship with severity and outcome. Journal of Stroke and Cerebrovascular Diseases 2003;12:82-7.

\section{RevMan 2014 [Computer program]}

Nordic Cochrane Centre, the Cochrane Collaboration. Review Manager 5 (RevMan 5). Version 5.3. Copenhagen: Nordic Cochrane Centre, the Cochrane Collaboration, 2014.

\section{Sandercock 2014}

Sandercock PAG, Counsell C, Tseng MC, Cecconi E. Oral antiplatelet therapy for acute ischaemic stroke. Cochrane Database of Systematic Reviews 2014, Issue 3. [DOI: 10.1002/14651858.CD000029.pub3]

\section{Sehara 2006}

Sehara Y, Hayashi T, Deguchi K, Nagotani S, Zhang H, Shoji M, et al. Distribution of inducible nitric oxide synthase and cell proliferation in rat brain after transient middle cerebral artery occlusion. Brain Research 2006;1093:190-7. 


\section{Sprigg 2006}

Sprigg N, Gray LJ, Bath PM, Boysen G, De Deyn PP, Friis P, TAIST Investigators. Relationship between outcome and baseline blood pressure and other haemodynamics in ischaemic stroke: data from the TAIST trial. Journal of Hypertension 2006;24(7):1413-7.

\section{Stroke Unit Trialists' Collaboration 2013}

Stroke Unit Triallists' Collaboration. Organised inpatient (stroke unit) care for stroke. Cochrane Database of Systematic Reviews 2013, Issue 9. [DOI: 10.1002/14651858.CD000197.pub3]

\section{Sun 2005}

Sun Y, Jin K, Childs JT, Xie L, Mao XO, Greenberg DA. Neuronal nitric oxide synthase and ischemia-induced neurogenesis. Journal of Cerebral Blood Flow \& Metabolism 2005;25:485-92.

\section{Tanaka 1996}

Tanaka K. Is nitric oxide really important for regulation of the cerebral circulation? Yes or no?. Keio Journal of Medicine 1996;45:14-27.

\section{Tikhonoff 2009}

Tikhonoff V, Zhang H, Richart T, Staessen JA. Blood pressure as a prognostic factor after acute stroke. Lancet Neurology 2009;8(10):938-48.

\section{Vahedi 2007}

Vahedi K, Hofmeijer J, Juettler E, Vicaut E, George B, Algra A, DECIMAL, DESTINY, and HAMLET investigators. Early decompressive surgery in malignant infarction of the middle cerebral artery: a pooled analysis of three randomised controlled trials. Lancet Neurology 2007;6(3):215-22.

\section{White 2000}

White RP, Vallance P, Markus HS. Effect of inhibition of nitric oxide synthase on dynamic cerebral autoregulation in humans. Clinical Science 2000;99:555-60.

\section{Willmot 2004}

Willmot M, Leonardi-Bee J, Bath PMW. High blood pressure in acute stroke and subsequent outcome - a systematic review. Hypertension 2004;43(1):18-24.

\section{Willmot 2005}

Willmot M, Gray L, Gibson C, Murphy S, Bath PMW. A systematic review of nitric oxide donors and L-arginine in experimental stroke; effects on infarct size and cerebral blood flow. Nitric Oxide 2005;12(3):141-9.

\section{Zaharchuk 1997}

Zaharchuk G, Hara H, Huang PL, Fishman MC, Moskowitz MA, Jenkins BG, et al. Neuronal nitric oxide synthase mutant mice show smaller infarcts and attenuated diffusion coefficient changes in the peri-infarct zone during focal cerebral ischemia. Magnetic Resonance in Medicine 1997;37:170-5.

\section{Zhang 1996}

Zhang F, Casey RM, Ross ME, Iadecola C. Aminoguanidine ameliorates and $\mathrm{L}$-arginine worsens brain damage from intraluminal middle cerebral artery occlusion. Stroke 1996;27:317-23.

\section{Zhao 2003}

Zhao X, Ross ME, ladecola C. L-arginine increases ischemic injury in wild-type mice but not in iNOS-deficient mice. Brain Research 2003;966:308-11.

\section{Zung 1965}

Zung WW. A self-rating depression scale. Archives of General Psychiatry 1965;12:63-70.

\section{References to other published versions of this review Bath 2002}

Bath PMW, Willmot MM, Leonardi-Bee J, Bath-Hextall FJ. Nitric oxide donors (nitrates), L-arginine, or nitric oxide synthase inhibitors for acute stroke. Cochrane Database of Systematic Reviews 2002, Issue 4. [DOI: 10.1002/14651858.CD000398]

* Indicates the major publication for the study

\section{CHARACTERISTICS OF STUDIES}

Characteristics of included studies [ordered by study ID]

Ankolekar 2013

\begin{tabular}{ll} 
Methods & Single-blind, blinded endpoint \\
& Randomisation $(1: 1)$ \\
\hline Participants & UK, single centre \\
& 41 participants: treatment 25 ; control 16 \\
& Mean age: treatment 79 years; control 81 years \\
& Male: treatment $15(65 \%)$; control $7(43.8 \%)$
\end{tabular}


Time to randomisation: within 4 hours of onset

\begin{tabular}{ll}
\hline Interventions & Treatment: transdermal GTN patch 5 mg once daily \\
& Control: no patch \\
& (Blinding with gauze dressing over patch/equivalent area of skin) \\
& Duration: 7 days \\
\hline Outcomes & Primary: systolic BP at 2 hours \\
& Secondary: \\
& - 15 minutes: systolic BP, diastolic BP, HR \\
& Day 7: SSS; recurrent stroke; death; hypotension; neurological deterioration (5-point decrease in SSS) \\
& Exclusion: requirement for or contraindication to nitrate therapy; GCS $\leq 8 ;$ blood glucose $<2.5$ mmol/L; \\
non-ambulatory prior to symptom onset
\end{tabular}

\section{Risk of bias}

\begin{tabular}{|c|c|c|}
\hline Bias & Authors' judgement & Support for judgement \\
\hline $\begin{array}{l}\text { Random sequence genera- } \\
\text { tion (selection bias) }\end{array}$ & Low risk & Simple randomisation. Equal distribution between trial groups \\
\hline $\begin{array}{l}\text { Allocation concealment } \\
\text { (selection bias) }\end{array}$ & Low risk & $\begin{array}{l}\text { Opaque envelope containing a gauze dressing }+/- \text { GTN patch was only opened } \\
\text { after consent was obtained }\end{array}$ \\
\hline $\begin{array}{l}\text { Blinding (performance } \\
\text { bias and detection bias) } \\
\text { All outcomes }\end{array}$ & Low risk & $\begin{array}{l}\text { GTN was given single-blinded (participant), whilst outcomes were assessed } \\
\text { blinded to treatment group }\end{array}$ \\
\hline $\begin{array}{l}\text { Blinding of participants } \\
\text { and personnel (perfor- } \\
\text { mance bias) } \\
\text { All outcomes }\end{array}$ & Unclear risk & $\begin{array}{l}\text { GTN was given single-blinded as no placebo patches were available. A gauze } \\
\text { dressing was placed over the GTN patch or equivalent area of skin out of sight. } \\
\text { As a result, participants were blinded whilst the treating clinician was unblind- } \\
\text { ed }\end{array}$ \\
\hline $\begin{array}{l}\text { Blinding of outcome as- } \\
\text { sessment (detection bias) } \\
\text { All outcomes }\end{array}$ & Low risk & Outcomes assessed blinded to treatment group \\
\hline $\begin{array}{l}\text { Incomplete outcome data } \\
\text { (attrition bias) } \\
\text { All outcomes }\end{array}$ & Low risk & All participants accounted for. No difference between trial groups \\
\hline $\begin{array}{l}\text { Selective reporting (re- } \\
\text { porting bias) }\end{array}$ & Low risk & All prespecified outcomes reported \\
\hline Other bias & Low risk & None found \\
\hline
\end{tabular}


Bath 2001

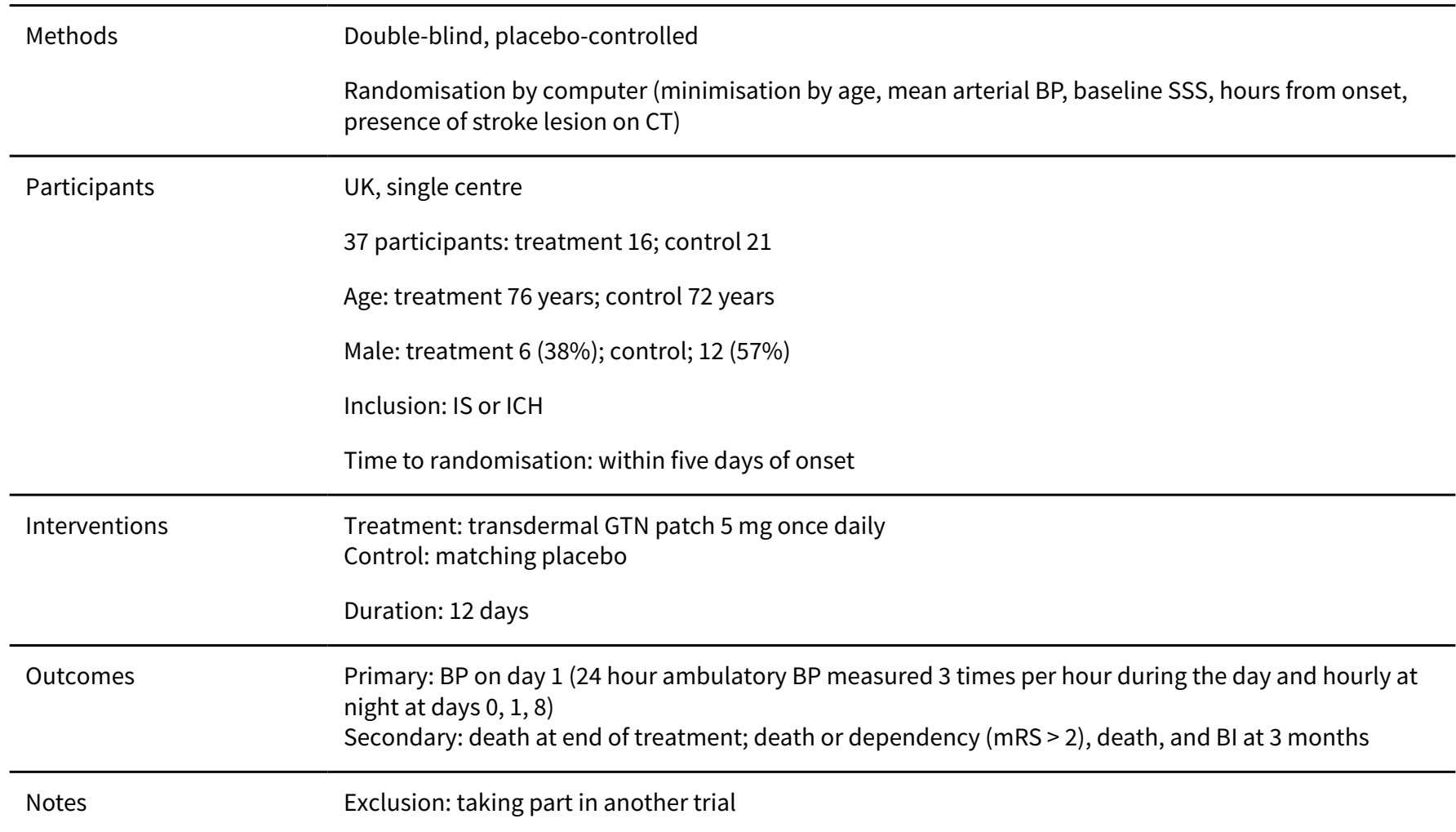

\section{Risk of bias}

Bias Authors' judgement Support for judgement

Random sequence genera- Low risk Computer randomisation with minimisation
tion (selection bias)

\begin{tabular}{lll}
\hline $\begin{array}{l}\text { Allocation concealment } \\
\text { (selection bias) }\end{array}$ & Low risk & Computer randomisation with minimisation \\
\hline $\begin{array}{l}\text { Blinding (performance } \\
\text { bias and detection bias) } \\
\text { All outcomes }\end{array}$ & Low risk & Matching treatment and placebo patches \\
\hline
\end{tabular}

Blinding of participants Low risk Matching treatment and placebo patches
and personnel (perfor-
mance bias)
All outcomes

\begin{tabular}{|c|c|c|}
\hline $\begin{array}{l}\text { Blinding of outcome as- } \\
\text { sessment (detection bias) } \\
\text { All outcomes }\end{array}$ & Low risk & Outcomes assessed blinded to treatment group \\
\hline $\begin{array}{l}\text { Incomplete outcome data } \\
\text { (attrition bias) } \\
\text { All outcomes }\end{array}$ & Low risk & No differences between trial groups \\
\hline $\begin{array}{l}\text { Selective reporting (re- } \\
\text { porting bias) }\end{array}$ & Low risk & All prespecified outcomes reported \\
\hline Other bias & Low risk & None found \\
\hline
\end{tabular}




\begin{tabular}{|c|c|}
\hline Methods & $\begin{array}{l}\text { Single-blind, parallel-group, partial factorial study } \\
\text { Randomisation via password-protected, data-encrypted website (minimisation by age, sex, stroke } \\
\text { severity, time to treatment and total anterior circulation syndrome) }\end{array}$ \\
\hline Participants & $\begin{array}{l}\text { International ( } 23 \text { countries), multicentre ( } 173 \text { sites) } \\
4011 \text { participants: treatment } 2000 \text {; control } 2011 \\
\text { Age: treatment } 70 \text { years; control } 70 \text { years } \\
\text { Male: treatment } 1147 \text { ( } 57 \%) \text {; control } 1150 \text { ( } 57 \%) \\
\text { Inclusion: IS or ICH; motor deficit in arm or leg, or both; systolic BP } 140 \text { to } 220 \text { mmHg } \\
\text { Time to randomisation: within } 48 \text { hours of onset }\end{array}$ \\
\hline Interventions & $\begin{array}{l}\text { - Treatment: transdermal GTN patch } 5 \text { mg once daily } \\
\text { In appropriate participants: } \\
\text { - Treatment: continue pre-stroke antihypertensive medication } \\
\text { - Control: stop pre-stroke antihypertensive medication } \\
\text { Duration: } 7 \text { days }\end{array}$ \\
\hline Outcomes & $\begin{array}{l}\text { Primary: } \mathrm{mRS} \text { at day } 90 \\
\text { Secondary: } \\
\text { - days } 1 \text { to } 7 \text { : BP and HR } \\
\text { - day 7: recurrent stroke } \\
\text { - discharge: length of hospital stay; disposition } \\
\text { - day 90: death or dependency (mRS > 2); BI; EQ-5D, EQ-VAS; MMSE, TICS-M; animal naming; Zung De- } \\
\text { pression Scale }\end{array}$ \\
\hline
\end{tabular}

Exclusions: GCS < 8; pure sensory stroke; preceding dependency (mRS 3 to 5); confounding neurologi-
cal or psychiatric illness; stroke mimic; severe liver or renal dysfunction; severe comorbidity; pregnant
or breastfeeding; planned surgical intervention; previous participation in ENOS 2015; contraindication
to or definite need for nitrates and/or prestroke antihypertensive medication

\section{Risk of bias}

\begin{tabular}{lll}
\hline Bias & Authors' judgement & Support for judgement \\
\hline $\begin{array}{l}\text { Random sequence genera- } \\
\text { tion (selection bias) }\end{array}$ & Low risk & Central computer randomisation with minimisation \\
\hline $\begin{array}{l}\text { Allocation concealment } \\
\text { (selection bias) }\end{array}$ & Low risk & Central website-based \\
\hline $\begin{array}{l}\text { Blinding (performance } \\
\text { bias and detection bias) } \\
\text { All outcomes }\end{array}$ & Low risk & $\begin{array}{l}\text { GTN was given single-blinded (participant), whilst outcomes were assessed } \\
\text { centrally and blinded to treatment group }\end{array}$ \\
\hline
\end{tabular}


ENOS 2015 (Continued)

\begin{tabular}{|c|c|c|}
\hline $\begin{array}{l}\text { Blinding of participants } \\
\text { and personnel (perfor- } \\
\text { mance bias) } \\
\text { All outcomes }\end{array}$ & Unclear risk & $\begin{array}{l}\text { GTN was given single-blinded as no placebo patches were available. A gauze } \\
\text { dressing was placed over the GTN patch or equivalent area of skin out of sight. } \\
\text { As a result, participants were blinded whilst the treating clinician was unblind- } \\
\text { ed }\end{array}$ \\
\hline
\end{tabular}

All outcomes

Low risk

Outcomes assessed centrally, blinded to treatment group

Blinding of outcome as-

All outcomes

\begin{tabular}{lll}
\hline $\begin{array}{l}\text { Incomplete outcome data } \\
\text { (attrition bias) } \\
\text { All outcomes }\end{array}$ & Low risk & No difference between trial groups \\
\hline $\begin{array}{l}\text { Selective reporting (re- } \\
\text { porting bias) }\end{array}$ & Low risk & All prespecified outcomes reported \\
\hline Other bias & Low risk & None found \\
\hline
\end{tabular}

Rashid 2002

\begin{tabular}{ll}
\hline Methods & Open-label, blinded endpoint dose comparison controlled trial \\
& Randomisation by computer (minimisation by age, gender, SSS, mean arterial pressure) \\
\hline Participants & 90 participants: treatment 60 ; control 30 \\
& Mean age: treatment 70.8 years; control 73.9 years \\
& Male: treatment 28 (46.7\%); control 13 (43.3\%) \\
& Inclusion: IS or ICH \\
& Time to randomisation: within 72 hours of onset \\
Treatment: transdermal GTN patch 5 mg for 10 days; 5 mg for 4 days, then 10 mg for 6 days; 10 mg for \\
10 days \\
Control: no patch \\
Duration: 10 days
\end{tabular}

Outcomes

Primary: BP on day 1 (24 hour ambulatory BP measured 3 times per hour during the day and hourly at night at days $0,1,4,5,10)$

Secondary: death at end of treatment; death or dependency ( $m R S>2$ ), death, BI and QoL at 3 months

Notes

Exclusion: systolic BP > 230 or < 100 mmHg; diastolic BP > 130 or $<60$ mmHg; HR > 130 or < 50 bpm; mild stroke; coma; premorbid dependence ( $\mathrm{mRS} \geq 3$ ); requirement for or contraindication to nitrate therapy; presence of illness that could confound neurological or functional evaluation

Any antihypertensive medication was stopped on admission and recommenced after 10 days

\section{Risk of bias}


Rashid 2002 (Continued)

\begin{tabular}{lll}
$\begin{array}{l}\text { Random sequence genera- } \\
\text { tion (selection bias) }\end{array}$ & Low risk & Computer randomisation with minimisation \\
\hline $\begin{array}{l}\text { Allocation concealment } \\
\text { (selection bias) }\end{array}$ & Low risk & Computer randomisation with minimisation \\
\hline
\end{tabular}

(selection bias)

\begin{tabular}{|c|c|c|}
\hline $\begin{array}{l}\text { Blinding (performance } \\
\text { bias and detection bias) }\end{array}$ & Low risk & $\begin{array}{l}\text { GTN was given single-blinded (participant), whilst outcomes were assessed } \\
\text { blinded to treatment group }\end{array}$ \\
\hline
\end{tabular}

\begin{tabular}{|c|c|c|}
\hline $\begin{array}{l}\text { Blinding of participants } \\
\text { and personnel (perfor- } \\
\text { mance bias) } \\
\text { All outcomes }\end{array}$ & Unclear risk & Open-label as no matching treatment and placebo patches were available \\
\hline $\begin{array}{l}\text { Blinding of outcome as- } \\
\text { sessment (detection bias) } \\
\text { All outcomes }\end{array}$ & Low risk & Outcomes assessed blinded to treatment group \\
\hline $\begin{array}{l}\text { Incomplete outcome data } \\
\text { (attrition bias) } \\
\text { All outcomes }\end{array}$ & Low risk & No differences between trial groups \\
\hline $\begin{array}{l}\text { Selective reporting (re- } \\
\text { porting bias) }\end{array}$ & Low risk & All prespecified outcomes reported \\
\hline Other bias & Low risk & None found \\
\hline
\end{tabular}

\section{Willmot 2006}

\begin{tabular}{ll}
\hline Methods & Participant- and measurement-blinded RCT \\
& $\begin{array}{l}\text { Randomisation by computer (2:1, minimisation by age, sex, baseline systolic BP, baseline SSS, time } \\
\text { from onset, presence of stroke lesion on CT) }\end{array}$ \\
\hline UK, single centre & 18 participants: treatment 12; control 6 \\
& Age: treatment 69 years; control 70 years \\
& Male: treatment 2 (16.7\%); control 3 (50\%) \\
& Inclusion: IS or ICH; previously independent; clinical stroke syndrome and limb weakness \\
& Time to randomisation: within 5 days of onset \\
Treatment: transdermal GTN patch 5 mg once daily \\
Control: no patch \\
(Blinding with gauze dressing over patch/equivalent area of skin) \\
Duration: 7 days \\
$\begin{array}{l}\text { Primary: BP (immediately before the baseline Xenon-CT and immediately after the post-treatment } \\
\text { scan), cerebral blood flow (Xenon-CT and transcranial doppler) and cerebral perfusion pressure (tran- } \\
\text { scranial doppler) }\end{array}$ \\
\hline Outcomes
\end{tabular}


Willmot 2006 (Continued)

\section{Secondary:}

- days 1 to $7: \mathrm{BP}$ and HR

- day 7: SSS, recurrent stroke, death, neurological deterioration

- day 90: mRS, BI, EQ-5D, EQ-VAS, MMSE, Zung Depression Scale

Notes

Exclusion: requirement for or contraindication to nitrate therapy; definite need for previous antihypertensive or vasoactive drugs; unable to cooperate with scanning

Prior antihypertensive medication was stopped on admission

\section{Risk of bias}

\begin{tabular}{|c|c|c|}
\hline Bias & Authors' judgement & Support for judgement \\
\hline $\begin{array}{l}\text { Random sequence genera- } \\
\text { tion (selection bias) }\end{array}$ & Low risk & Computer randomisation with minimisation \\
\hline $\begin{array}{l}\text { Allocation concealment } \\
\text { (selection bias) }\end{array}$ & Low risk & Computer randomisation with minimisation \\
\hline $\begin{array}{l}\text { Blinding (performance } \\
\text { bias and detection bias) } \\
\text { All outcomes }\end{array}$ & Low risk & $\begin{array}{l}\text { GTN was given single-blinded (participant), whilst outcomes were assessed } \\
\text { blinded to treatment group }\end{array}$ \\
\hline $\begin{array}{l}\text { Blinding of participants } \\
\text { and personnel (perfor- } \\
\text { mance bias) } \\
\text { All outcomes }\end{array}$ & Unclear risk & $\begin{array}{l}\text { GTN was given single-blinded as no placebo patches were available. A gauze } \\
\text { dressing was placed over the GTN patch or equivalent area of skin out of sight. } \\
\text { As a result, participants were blinded whilst the treating clinician was unblind- } \\
\text { ed }\end{array}$ \\
\hline $\begin{array}{l}\text { Blinding of outcome as- } \\
\text { sessment (detection bias) } \\
\text { All outcomes }\end{array}$ & Low risk & Outcomes assessed blinded to treatment group \\
\hline $\begin{array}{l}\text { Incomplete outcome data } \\
\text { (attrition bias) } \\
\text { All outcomes }\end{array}$ & Low risk & All participants accounted for \\
\hline $\begin{array}{l}\text { Selective reporting (re- } \\
\text { porting bias) }\end{array}$ & Low risk & All prespecified outcomes reported \\
\hline Other bias & Low risk & None found \\
\hline
\end{tabular}

BI: Barthel Index

bpm: beats per minute

BP: blood pressure

CT: computed tomography

DBP: diastolic blood pressure

EQ-5D: European Quality of life - 5 Dimensions

EQ-VAS: European Quality of life - Visual Analogue Scale

GCS: Glasgow Coma Scale

GTN: glyceryl trinitrate

HR: heart rate

$\mathrm{ICH}$ : intracerebral haemorrhage

IS: ischaemic stroke

MMSE: Mini Mental State Examination

mRS: modified Rankin Scale

QoL: quality of life 
SBP: systolic blood pressure

SSS: Scandinavian Stroke Scale

TICS-M: Modified Telephone Interview Cognition Scale

Characteristics of excluded studies [ordered by study ID]

\begin{tabular}{|c|c|}
\hline Study & Reason for exclusion \\
\hline Butterworth 1998 & Nonrandomised study assessing sodium nitroprusside in acute IS \\
\hline El Mously 2014 & Case-control study \\
\hline El-Zammer 2012 & Not randomised or controlled \\
\hline FAST-BP 2013 & Not randomised or controlled (ongoing) \\
\hline Flinders 2014 & $\begin{array}{l}\text { Nonrandomised study as part of Field Administration of Stroke Therapy-Magnesium (FAST-MAG) } \\
\text { clinical trial }\end{array}$ \\
\hline Kate 2015 & $\begin{array}{l}\text { Nonrandomised, controlled study assessing treatment with sublingual nitroglycerin +/-intra- } \\
\text { venous labetalol depending on baseline systolic BP on CBF }\end{array}$ \\
\hline Kerr 2000 & Unable to obtain published or unpublished data \\
\hline MAPAS 2009 & Non-controlled, target-based study (ongoing) \\
\hline Nakamura 2010 & $\begin{array}{l}\text { Head-to-head comparison study comparing perindopril vs candesartan vs conventional therapy } \\
\text { (including nitrates) }\end{array}$ \\
\hline PATICH 2014 & Target-based study (ongoing) \\
\hline PATIS 2009 & Non-randomised, target-based study (ongoing) \\
\hline Roitberg 2008 & $\begin{array}{l}\text { Confounded randomised controlled trial of nicardipine versus sodium nitroprusside in ICH and } \\
\text { subarachnoid haemorrhage }\end{array}$ \\
\hline Sakamoto 2015 & Not randomised or controlled \\
\hline Sanossian 2012 & Nonrandomised study as part of FAST-MAG clinical trial \\
\hline Suri 2009 & Retrospective study on the use of nicardipine or sodium nitroprusside in $\mathrm{ICH}$ \\
\hline Xu 2007 & Assessing vertebrobasilar insufficiency, not acute stroke \\
\hline
\end{tabular}

CBF: cerebral blood flow

$\mathrm{ICH}$ : intracerebral haemorrhage

IS: ischaemic stroke

SBP: systolic blood pressure

vs: versus

Characteristics of ongoing studies [ordered by study ID]

RIGHT-2 2015

Trial name or title

Rapid Intervention with Glyceryl trinitrate in Hypertensive stroke Trial-2 (RIGHT-2)

Methods

Prospective multicentre single-blind randomised controlled trial 
RIGHT-2 2015 (Continued)

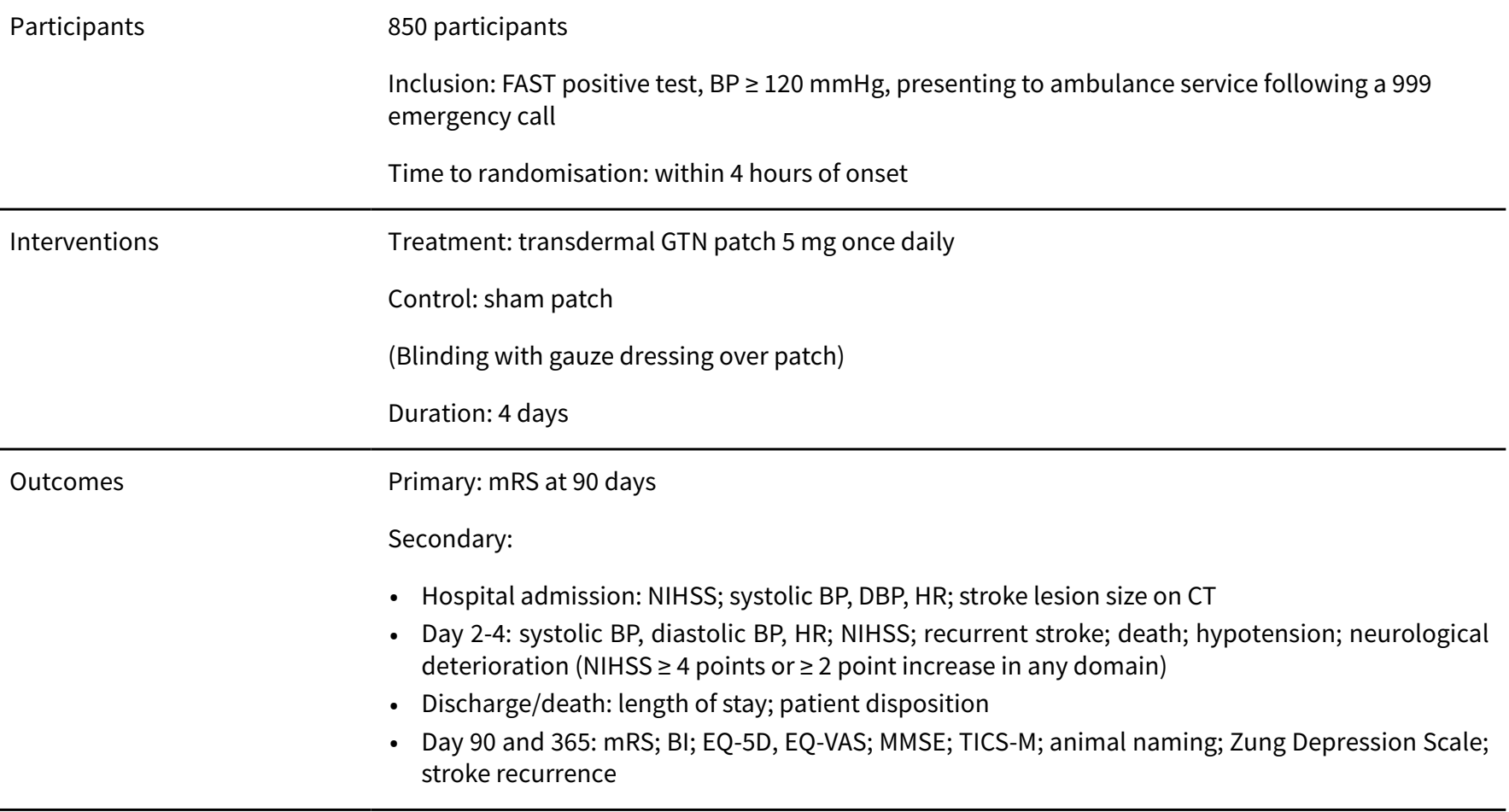

\begin{tabular}{ll}
\hline Starting date & October 2015 \\
\hline Contact information & Philip Bath, Stroke Association Professor of Stroke Medicine, Stroke, Division of Clinical Neuro- \\
& science, B52, Clinical Sciences Building, University of Nottingham, City Hospital Campus, Hucknall \\
& Road, Nottingham, NG5 1PB (philip.bath@nottingham.ac.uk) \\
\hline
\end{tabular}

Notes

BI: Barthel index

BP: Blood pressure

CT: Computed tomography

DBP: Diastolic blood pressure

EQ-5D: European quality of life-5 dimensions

EQ-VAS: European quality of life-visual analogue scale

GTN: Glyceryl trinitrate

HR: Heart rate

$\mathrm{ICH}$ : Intracerebral haemorrhage

IS: Ischaemic stroke

MMSE: Mini-mental state examination

MRI: Magnetic resonance imaging

mRS: Modified Rankin scale

NIHSS: National Institutes of Health Stroke Scale

QoL: Quality of life

SBP: Systolic blood pressure

SSS: Scandanavian stroke scale

TICS-M: modified Telephone Interview for Cognitive Status

\section{DATA AND ANALYSES}


Comparison 1. Glyceryl trinitrate (GTN) compared with no GTN for acute stroke

\begin{tabular}{|c|c|c|c|c|}
\hline $\begin{array}{l}\text { Outcome or subgroup ti- } \\
\text { tle }\end{array}$ & No. of studies & $\begin{array}{l}\text { No. of partici- } \\
\text { pants }\end{array}$ & Statistical method & Effect size \\
\hline $\begin{array}{l}1 \text { Death or dependency } \\
(m R S>2) \text {, end of trial }\end{array}$ & 5 & 4195 & Odds Ratio (M-H, Random, 95\% Cl) & $0.97[0.86,1.10]$ \\
\hline 1.1 Overall & 5 & 4195 & Odds Ratio (M-H, Random, 95\% Cl) & $0.97[0.86,1.10]$ \\
\hline $\begin{array}{l}2 \text { Death or dependency } \\
\text { (mRS }>2) \text {, end of trial, by } \\
\text { stroke type }\end{array}$ & 5 & 4143 & Odds Ratio (M-H, Random, 95\% Cl) & $1.00[0.81,1.23]$ \\
\hline 2.1 Ischaemic & 5 & 3502 & Odds Ratio (M-H, Random, 95\% Cl) & $0.97[0.62,1.53]$ \\
\hline $\begin{array}{l}2.2 \text { Intracerebral haemor- } \\
\text { rhage }\end{array}$ & 4 & 641 & Odds Ratio (M-H, Random, 95\% Cl) & $1.20[0.45,3.21]$ \\
\hline $\begin{array}{l}3 \text { Death or dependency } \\
(\mathrm{mRS}>2) \text {, end of trial, by } \\
\text { time to randomisation }\end{array}$ & 5 & 4194 & Odds Ratio (M-H, Random, 95\% Cl) & $0.97[0.86,1.10]$ \\
\hline $3.1<6$ hours & 2 & 312 & Odds Ratio (M-H, Random, 95\% Cl) & $0.65[0.41,1.02]$ \\
\hline 3.26 .1 to 12 hours & 2 & 440 & Odds Ratio (M-H, Random, 95\% Cl) & $1.21[0.83,1.77]$ \\
\hline 3.312 .1 to 24 hours & 2 & 1070 & Odds Ratio (M-H, Random, 95\% Cl) & $0.97[0.76,1.24]$ \\
\hline 3.424 .1 to 36 hours & 3 & 1218 & Odds Ratio (M-H, Random, 95\% Cl) & $1.05[0.83,1.33]$ \\
\hline $3.5>36$ hours & 4 & 1154 & Odds Ratio (M-H, Random, 95\% Cl) & $0.91[0.72,1.16]$ \\
\hline $\begin{array}{l}4 \text { Death or dependency } \\
(\mathrm{mRS}>2) \text {, end of trial, by } \\
\text { baseline SBP }\end{array}$ & 5 & 4193 & Odds Ratio (M-H, Random, 95\% Cl) & $0.97[0.85,1.10]$ \\
\hline $4.1<160 \mathrm{mmHg}$ & 5 & 1706 & Odds Ratio (M-H, Random, 95\% Cl) & $1.00[0.82,1.21]$ \\
\hline 4.2160 .1 to $180 \mathrm{mmHg}$ & 5 & 1480 & Odds Ratio (M-H, Random, 95\% Cl) & $0.78[0.23,2.60]$ \\
\hline 4.3180 .1 to $200 \mathrm{mmHg}$ & 5 & 747 & Odds Ratio (M-H, Random, 95\% Cl) & $0.95[0.70,1.28]$ \\
\hline $4.4>200 \mathrm{mmHg}$ & 3 & 260 & Odds Ratio (M-H, Random, 95\% Cl) & $0.89[0.53,1.48]$ \\
\hline $\begin{array}{l}5 \text { Death or dependency } \\
\text { (mean mRS), end of trial }\end{array}$ & 5 & 4195 & Mean Difference (IV, Random, 95\% CI) & $-0.08[-0.52,0.36]$ \\
\hline 5.1 Overall & 5 & 4195 & Mean Difference (IV, Random, 95\% CI) & $-0.08[-0.52,0.36]$ \\
\hline $\begin{array}{l}6 \text { Death or dependency } \\
\text { (mean mRS), end of trial, } \\
\text { by stroke type }\end{array}$ & 5 & 4143 & Mean Difference (IV, Random, 95\% CI) & $-0.05[-0.31,0.21]$ \\
\hline 6.1 Ischaemic & 5 & 3502 & Mean Difference (IV, Random, 95\% CI) & $-0.13[-0.62,0.35]$ \\
\hline $6.2 \mathrm{ICH}$ & 4 & 641 & Mean Difference (IV, Random, 95\% CI) & $0.02[-0.24,0.28]$ \\
\hline
\end{tabular}




\begin{tabular}{|c|c|c|c|c|}
\hline $\begin{array}{l}\text { Outcome or subgroup ti- } \\
\text { tle }\end{array}$ & No. of studies & $\begin{array}{l}\text { No. of partici- } \\
\text { pants }\end{array}$ & Statistical method & Effect size \\
\hline $\begin{array}{l}7 \text { Death or dependency } \\
\text { (mean mRS), end of trial, } \\
\text { by time to randomisation }\end{array}$ & 5 & 4194 & Mean Difference (IV, Random, 95\% CI) & $-0.08[-0.27,0.11]$ \\
\hline $7.1<6$ hours & 2 & 312 & Mean Difference (IV, Random, 95\% CI) & $-0.79[-1.35,-0.23]$ \\
\hline 7.26 .1 to 12 hours & 2 & 440 & Mean Difference (IV, Random, 95\% CI) & $0.19[-0.15,0.53]$ \\
\hline 7.312 .1 to 24 hours & 2 & 1070 & Mean Difference (IV, Random, 95\% CI) & $-0.03[-0.24,0.18]$ \\
\hline 7.424 .1 to 36 hours & 3 & 1218 & Mean Difference (IV, Random, 95\% CI) & $0.06[-0.13,0.25]$ \\
\hline $7.5>36$ hours & 4 & 1154 & Mean Difference (IV, Random, 95\% CI) & $-0.04[-0.35,0.28]$ \\
\hline $\begin{array}{l}8 \text { Death or dependency } \\
\text { (mean } \mathrm{mRS} \text { ), end of trial, } \\
\text { by baseline SBP }\end{array}$ & 5 & 4193 & Mean Difference (IV, Random, 95\% CI) & $-0.04[-0.26,0.17]$ \\
\hline $8.1<160 \mathrm{mmHg}$ & 5 & 1706 & Mean Difference (IV, Random, 95\% CI) & $0.01[-0.16,0.17]$ \\
\hline $8.2160 .1-180 \mathrm{mmHg}$ & 5 & 1480 & Mean Difference (IV, Random, 95\% CI) & $-0.38[-1.42,0.66]$ \\
\hline $8.3180 .1-200 \mathrm{mmHg}$ & 5 & 747 & Mean Difference (IV, Random, 95\% CI) & $0.04[-0.20,0.28]$ \\
\hline $8.4>200 \mathrm{mmHg}$ & 3 & 260 & Mean Difference (IV, Random, 95\% CI) & $-0.26[-0.70,0.17]$ \\
\hline 9 Death, end of treatment & 5 & 4197 & Odds Ratio (M-H, Random, 95\% Cl) & $1.09[0.76,1.56]$ \\
\hline 9.1 Overall & 5 & 4197 & Odds Ratio (M-H, Random, 95\% Cl) & $1.09[0.76,1.56]$ \\
\hline $\begin{array}{l}10 \text { Death, end of treat- } \\
\text { ment, by stroke type }\end{array}$ & 5 & 4143 & Odds Ratio (M-H, Random, 95\% Cl) & $1.04[0.73,1.49]$ \\
\hline 10.1 Ischaemic & 5 & 3502 & Odds Ratio (M-H, Random, 95\% Cl) & $1.02[0.69,1.51]$ \\
\hline $10.2 \mathrm{ICH}$ & 4 & 641 & Odds Ratio (M-H, Random, 95\% Cl) & $1.16[0.50,2.69]$ \\
\hline $\begin{array}{l}11 \text { Death, end of treat- } \\
\text { ment, by time to randomi- } \\
\text { sation }\end{array}$ & 5 & 4195 & Odds Ratio (M-H, Random, 95\% Cl) & $1.07[0.74,1.54]$ \\
\hline $11.1<6$ hours & 2 & 312 & Odds Ratio (M-H, Random, 95\% Cl) & $0.82[0.28,2.43]$ \\
\hline 11.26 .1 to 12 hours & 2 & 440 & Odds Ratio (M-H, Random, 95\% Cl) & $1.69[0.49,5.87]$ \\
\hline 11.312 .1 to 24 hours & 2 & 1070 & Odds Ratio (M-H, Random, 95\% Cl) & $0.84[0.46,1.54]$ \\
\hline 11.424 .1 to 36 hours & 3 & 1218 & Odds Ratio (M-H, Random, 95\% Cl) & $1.90[0.90,4.00]$ \\
\hline $11.5>36$ hours & 4 & 1155 & Odds Ratio (M-H, Random, 95\% Cl) & $0.80[0.35,1.80]$ \\
\hline $\begin{array}{l}12 \text { Death, end of treat- } \\
\text { ment, by baseline SBP }\end{array}$ & 5 & 4196 & Odds Ratio (M-H, Random, 95\% Cl) & $1.09[0.76,1.56]$ \\
\hline
\end{tabular}




\begin{tabular}{|c|c|c|c|c|}
\hline $\begin{array}{l}\text { Outcome or subgroup ti- } \\
\text { tle }\end{array}$ & No. of studies & $\begin{array}{l}\text { No. of partici- } \\
\text { pants }\end{array}$ & Statistical method & Effect size \\
\hline $12.1<160 \mathrm{mmHg}$ & 5 & 1706 & Odds Ratio (M-H, Random, 95\% Cl) & $1.46[0.83,2.56]$ \\
\hline $12.2160 .1-180 \mathrm{mmHg}$ & 5 & 1480 & Odds Ratio (M-H, Random, 95\% Cl) & $0.85[0.47,1.54]$ \\
\hline 12.3180 .1 to $200 \mathrm{mmHg}$ & 5 & 748 & Odds Ratio (M-H, Random, 95\% Cl) & $0.67[0.28,1.65]$ \\
\hline $12.4>200 \mathrm{mmHg}$ & 4 & 262 & Odds Ratio (M-H, Random, 95\% Cl) & $2.13[0.60,7.61]$ \\
\hline 13 Death, end of trial & 5 & 4197 & Odds Ratio (M-H, Random, 95\% Cl) & $0.78[0.40,1.50]$ \\
\hline 13.1 Overall & 5 & 4197 & Odds Ratio (M-H, Random, 95\% Cl) & $0.78[0.40,1.50]$ \\
\hline $\begin{array}{l}14 \text { Death, end of trial, by } \\
\text { stroke type }\end{array}$ & 5 & 4143 & Odds Ratio (M-H, Random, 95\% Cl) & $0.86[0.72,1.04]$ \\
\hline 14.1 Ischaemic & 5 & 3502 & Odds Ratio (M-H, Random, 95\% Cl) & $0.85[0.69,1.05]$ \\
\hline $14.2 \mathrm{ICH}$ & 4 & 641 & Odds Ratio (M-H, Random, 95\% Cl) & $1.08[0.22,5.21]$ \\
\hline $\begin{array}{l}15 \text { Death, end of trial, by } \\
\text { time to randomisation }\end{array}$ & 5 & 4195 & Odds Ratio (M-H, Random, 95\% Cl) & $0.81[0.58,1.14]$ \\
\hline $15.1<6$ hours & 2 & 312 & Odds Ratio (M-H, Random, 95\% Cl) & $0.30[0.15,0.60]$ \\
\hline 15.26 .1 to 12 hours & 2 & 440 & Odds Ratio (M-H, Random, 95\% Cl) & $1.34[0.79,2.25]$ \\
\hline 15.312 .1 to 24 hours & 2 & 1070 & Odds Ratio (M-H, Random, 95\% Cl) & $1.52[0.20,11.53]$ \\
\hline 15.424 .1 to 36 hours & 3 & 1218 & Odds Ratio (M-H, Random, 95\% Cl) & $0.98[0.69,1.37]$ \\
\hline $15.5>36$ hours & 4 & 1155 & Odds Ratio (M-H, Random, 95\% Cl) & $0.81[0.27,2.44]$ \\
\hline $\begin{array}{l}16 \text { Death, end of trial, by } \\
\text { baseline SBP }\end{array}$ & 5 & 4196 & Odds Ratio (M-H, Random, 95\% Cl) & $0.87[0.72,1.05]$ \\
\hline $16.1<160 \mathrm{mmHg}$ & 5 & 1706 & Odds Ratio (M-H, Random, 95\% Cl) & $0.95[0.71,1.27]$ \\
\hline 16.2160 .1 to $180 \mathrm{mmHg}$ & 5 & 1480 & Odds Ratio (M-H, Random, 95\% Cl) & $0.79[0.44,1.41]$ \\
\hline 16.3180 .1 to $200 \mathrm{mmHg}$ & 5 & 748 & Odds Ratio (M-H, Random, 95\% Cl) & $0.85[0.54,1.33]$ \\
\hline $16.4>200 \mathrm{mmHg}$ & 4 & 262 & Odds Ratio (M-H, Random, 95\% Cl) & $0.78[0.40,1.50]$ \\
\hline $\begin{array}{l}17 \text { Neurological deteriora- } \\
\text { tion, end of treatment }\end{array}$ & 4 & 4158 & Odds Ratio (M-H, Random, 95\% Cl) & $1.24[0.97,1.60]$ \\
\hline 17.1 Overall & 4 & 4158 & Odds Ratio (M-H, Random, 95\% Cl) & $1.24[0.97,1.60]$ \\
\hline $\begin{array}{l}18 \text { Neurological deteriora- } \\
\text { tion, end of treatment, by } \\
\text { stroke type }\end{array}$ & 4 & 4106 & Odds Ratio (M-H, Random, 95\% Cl) & $1.17[0.74,1.86]$ \\
\hline 18.1 Ischaemic & 4 & 3469 & Odds Ratio (M-H, Random, 95\% Cl) & $0.58[0.09,3.75]$ \\
\hline
\end{tabular}




\begin{tabular}{|c|c|c|c|c|}
\hline $\begin{array}{l}\text { Outcome or subgroup ti- } \\
\text { tle }\end{array}$ & No. of studies & $\begin{array}{l}\text { No. of partici- } \\
\text { pants }\end{array}$ & Statistical method & Effect size \\
\hline $18.2 \mathrm{ICH}$ & 3 & 637 & Odds Ratio (M-H, Random, 95\% Cl) & $1.46[0.83,2.57]$ \\
\hline $\begin{array}{l}19 \text { Neurological deteriora- } \\
\text { tion, end of treatment, by } \\
\text { time to randomisation }\end{array}$ & 4 & 4159 & Odds Ratio (M-H, Random, 95\% Cl) & $1.18[0.81,1.72]$ \\
\hline $19.1<6$ hours & 2 & 312 & Odds Ratio (M-H, Random, 95\% Cl) & $0.57[0.28,1.16]$ \\
\hline 19.26 .1 to 12 hours & 2 & 440 & Odds Ratio (M-H, Random, 95\% Cl) & $2.11[0.93,4.78]$ \\
\hline 19.312 .1 to 24 hours & 2 & 1070 & Odds Ratio (M-H, Random, 95\% Cl) & $1.18[0.74,1.88]$ \\
\hline 19.424 .1 to 36 hours & 3 & 1218 & Odds Ratio (M-H, Random, 95\% Cl) & $2.00[1.19,3.35]$ \\
\hline $19.5>36$ hours & 3 & 1119 & Odds Ratio (M-H, Random, 95\% Cl) & $0.93[0.55,1.59]$ \\
\hline $\begin{array}{l}20 \text { Neurological deteriora- } \\
\text { tion, end of treatment, by } \\
\text { baseline SBP }\end{array}$ & 4 & 4159 & Odds Ratio (M-H, Random, 95\% Cl) & $1.22[0.88,1.68]$ \\
\hline 20.1 Baseline SBP $<160$ & 4 & 1688 & Odds Ratio (M-H, Random, 95\% Cl) & $1.62[1.05,2.50]$ \\
\hline $\begin{array}{l}20.2 \text { Baseline SBP } 160.1 \text { to } \\
180\end{array}$ & 4 & 1468 & Odds Ratio (M-H, Random, 95\% Cl) & $0.88[0.58,1.35]$ \\
\hline $\begin{array}{l}20.3 \text { Baseline SBP } 180.1 \text { to } \\
200\end{array}$ & 4 & 743 & Odds Ratio (M-H, Random, 95\% Cl) & $1.81[1.05,3.12]$ \\
\hline 20.4 Baseline SBP > 200 & 3 & 260 & Odds Ratio (M-H, Random, 95\% Cl) & $0.63[0.25,1.57]$ \\
\hline $\begin{array}{l}21 \mathrm{NIH} \text { Stroke Scale, end of } \\
\text { treatment }\end{array}$ & 4 & 4137 & Mean Difference (IV, Random, 95\% Cl) & $-0.28[-0.70,0.14]$ \\
\hline 21.1 Overall & 4 & 4137 & Mean Difference (IV, Random, 95\% Cl) & $-0.28[-0.70,0.14]$ \\
\hline $\begin{array}{l}22 \mathrm{NIH} \text { Stroke Scale, end of } \\
\text { treatment, by stroke type }\end{array}$ & 4 & 4085 & Mean Difference (IV, Random, 95\% CI) & $-0.19[-1.19,0.81]$ \\
\hline 22.1 Ischaemic & 4 & 3452 & Mean Difference (IV, Random, 95\% CI) & $-0.47[-2.39,1.45]$ \\
\hline $22.2 \mathrm{ICH}$ & 3 & 633 & Mean Difference (IV, Random, 95\% CI) & $0.12[-0.94,1.18]$ \\
\hline $\begin{array}{l}23 \text { NIH Stroke Scale, end of } \\
\text { treatment, by time to ran- } \\
\text { domisation }\end{array}$ & 4 & 4136 & Mean Difference (IV, Random, 95\% CI) & $-0.32[-0.88,0.25]$ \\
\hline $23.1<6$ hours & 2 & 309 & Mean Difference (IV, Random, 95\% CI) & $-2.07[-3.81,-0.34]$ \\
\hline 23.26 .1 to 12 hours & 2 & 440 & Mean Difference (IV, Random, 95\% CI) & $1.17[-0.14,2.48]$ \\
\hline $23.312 .1-24$ hours & 2 & 1062 & Mean Difference (IV, Random, 95\% CI) & $-0.26[-1.13,0.61]$ \\
\hline 23.424 .1 to 36 hours & 3 & 1213 & Mean Difference (IV, Random, 95\% CI) & $-0.07[-0.81,0.68]$ \\
\hline $23.5>36$ hours & 3 & 1112 & Mean Difference (IV, Random, 95\% CI) & $-0.72[-1.50,0.05]$ \\
\hline
\end{tabular}




\begin{tabular}{|c|c|c|c|c|}
\hline $\begin{array}{l}\text { Outcome or subgroup ti- } \\
\text { tle }\end{array}$ & No. of studies & $\begin{array}{l}\text { No. of partici- } \\
\text { pants }\end{array}$ & Statistical method & Effect size \\
\hline $\begin{array}{l}24 \text { NIH Stroke Scale, end } \\
\text { of treatment, by baseline } \\
\text { SBP }\end{array}$ & 4 & 4135 & Mean Difference (IV, Random, 95\% Cl) & $-0.16[-0.65,0.33]$ \\
\hline $24.1<160 \mathrm{mmHg}$ & 4 & 1681 & Mean Difference (IV, Random, 95\% Cl) & $-0.15[-1.04,0.75]$ \\
\hline 24.2160 .1 to $180 \mathrm{mmHg}$ & 4 & 1454 & Mean Difference (IV, Random, 95\% CI) & $-0.47[-2.32,1.38]$ \\
\hline 24.3180 .1 to $200 \mathrm{mmHg}$ & 4 & 741 & Mean Difference (IV, Random, 95\% Cl) & $-0.11[-1.05,0.83]$ \\
\hline $24.4>200 \mathrm{mmHg}$ & 3 & 259 & Mean Difference (IV, Random, 95\% CI) & $0.29[-1.46,2.04]$ \\
\hline $\begin{array}{l}25 \text { Barthel Index, end of } \\
\text { trial }\end{array}$ & 5 & 4153 & Mean Difference (IV, Random, 95\% CI) & $-0.09[-5.39,5.20]$ \\
\hline 25.1 Overall & 5 & 4153 & Mean Difference (IV, Random, 95\% CI) & $-0.09[-5.39,5.20]$ \\
\hline $\begin{array}{l}26 \text { Barthel Index, end of } \\
\text { trial, by stroke type }\end{array}$ & 5 & 4100 & Mean Difference (IV, Random, 95\% CI) & $0.57[-3.72,4.87]$ \\
\hline 26.1 Ischaemic & 5 & 3466 & Mean Difference (IV, Random, 95\% CI) & $0.60[-5.27,6.47]$ \\
\hline $26.2 \mathrm{ICH}$ & 4 & 634 & Mean Difference (IV, Random, 95\% CI) & $0.92[-5.19,7.03]$ \\
\hline $\begin{array}{l}27 \text { Barthel Index, end of } \\
\text { trial, by time to randomi- } \\
\text { sation }\end{array}$ & 5 & 4152 & Mean Difference (IV, Random, 95\% Cl) & $1.81[-1.62,5.25]$ \\
\hline $27.1<6$ hours & 2 & 312 & Mean Difference (IV, Random, 95\% CI) & $14.57[5.95,23.19]$ \\
\hline 27.26 .1 to 12 hours & 2 & 434 & Mean Difference (IV, Random, 95\% Cl) & $-3.47[-11.00,4.06]$ \\
\hline 27.312 .1 to 24 hours & 2 & 1057 & Mean Difference (IV, Random, 95\% CI) & $1.49[-3.21,6.19]$ \\
\hline 27.424 .1 to 36 hours & 3 & 1205 & Mean Difference (IV, Random, 95\% Cl) & $0.59[-3.81,4.98]$ \\
\hline $27.5>36$ hours & 4 & 1144 & Mean Difference (IV, Random, 95\% CI) & $0.50[-4.88,5.89]$ \\
\hline $\begin{array}{l}28 \text { Barthel Index, end of } \\
\text { trial, by baseline SBP }\end{array}$ & 5 & 4150 & Mean Difference (IV, Random, 95\% CI) & $0.66[-3.00,4.32]$ \\
\hline $28.1<160 \mathrm{mmHg}$ & 5 & 1687 & Mean Difference (IV, Random, 95\% Cl) & $0.47[-2.89,3.83]$ \\
\hline 28.2160 .1 to $180 \mathrm{mmHg}$ & 5 & 1464 & Mean Difference (IV, Random, 95\% CI) & $4.30[-8.25,16.85]$ \\
\hline 28.3180 .1 to $200 \mathrm{mmHg}$ & 5 & 741 & Mean Difference (IV, Random, 95\% CI) & $0.28[-5.36,5.91]$ \\
\hline $28.4>200 \mathrm{mmHg}$ & 3 & 258 & Mean Difference (IV, Random, 95\% CI) & $7.74[-2.49,17.97]$ \\
\hline $\begin{array}{l}29 \text { Mood (Zung), end of tri- } \\
\text { al }\end{array}$ & 3 & 3312 & Mean Difference (IV, Random, 95\% Cl) & $-0.83[-4.44,2.79]$ \\
\hline 29.1 Overall & 3 & 3312 & Mean Difference (IV, Random, 95\% CI) & $-0.83[-4.44,2.79]$ \\
\hline
\end{tabular}




\begin{tabular}{|c|c|c|c|c|}
\hline $\begin{array}{l}\text { Outcome or subgroup ti- } \\
\text { tle }\end{array}$ & No. of studies & $\begin{array}{l}\text { No. of partici- } \\
\text { pants }\end{array}$ & Statistical method & Effect size \\
\hline $\begin{array}{l}30 \text { Mood (Zung), end of tri- } \\
\text { al, by stroke type }\end{array}$ & 3 & 3269 & Mean Difference (IV, Random, 95\% CI) & $-0.54[-2.20,1.12]$ \\
\hline 30.1 Ischaemic & 3 & 2745 & Mean Difference (IV, Random, 95\% CI) & $-1.04[-7.81,5.72]$ \\
\hline $30.2 \mathrm{ICH}$ & 3 & 524 & Mean Difference (IV, Random, 95\% CI) & $0.51[-3.67,4.69]$ \\
\hline $\begin{array}{l}31 \text { Mood (Zung), end of tri- } \\
\text { al, by time to randomisa- } \\
\text { tion }\end{array}$ & 3 & 3311 & Mean Difference (IV, Random, 95\% CI) & $-1.24[-4.38,1.91]$ \\
\hline $31.1<6$ hours & 2 & 268 & Mean Difference (IV, Random, 95\% CI) & $-11.12[-17.35,-4.90]$ \\
\hline 31.26 .1 to 12 hours & 2 & 372 & Mean Difference (IV, Random, 95\% CI) & $2.55[-2.58,7.68]$ \\
\hline 31.312 .1 to 24 hours & 1 & 834 & Mean Difference (IV, Random, 95\% CI) & $0.98[-2.34,4.30]$ \\
\hline 31.424 .1 to 36 hours & 2 & 989 & Mean Difference (IV, Random, 95\% CI) & $0.42[-2.58,3.42]$ \\
\hline $31.5>36$ hours & 2 & 848 & Mean Difference (IV, Random, 95\% CI) & $-1.54[-4.66,1.57]$ \\
\hline $\begin{array}{l}32 \text { Mood (Zung), end of tri- } \\
\text { al, by baseline SBP }\end{array}$ & 3 & 3312 & Mean Difference (IV, Random, 95\% CI) & $-0.41[-2.06,1.24]$ \\
\hline $32.1<160 \mathrm{mmHg}$ & 3 & 1344 & Mean Difference (IV, Random, 95\% CI) & $1.19[-9.36,11.75]$ \\
\hline 32.2160 .1 to $180 \mathrm{mmHg}$ & 3 & 1179 & Mean Difference (IV, Random, 95\% CI) & $-0.33[-3.09,2.43]$ \\
\hline 32.3180 .1 to $200 \mathrm{mmHg}$ & 3 & 582 & Mean Difference (IV, Random, 95\% CI) & $-0.19[-4.07,3.69]$ \\
\hline $32.4>200 \mathrm{mmHg}$ & 2 & 207 & Mean Difference (IV, Random, 95\% CI) & $-4.32[-11.37,2.74]$ \\
\hline 33 EQ5D-3L, end of trial & 4 & 4088 & Mean Difference (IV, Random, 95\% CI) & $-0.01[-0.17,0.15]$ \\
\hline 33.1 Overall & 4 & 4088 & Mean Difference (IV, Random, 95\% CI) & $-0.01[-0.17,0.15]$ \\
\hline $\begin{array}{l}34 \text { EQ5D-3L, end of trial, } \\
\text { by stroke type }\end{array}$ & 4 & 4084 & Mean Difference (IV, Random, 95\% CI) & $0.01[-0.08,0.09]$ \\
\hline 34.1 Ischaemic & 4 & 3457 & Mean Difference (IV, Random, 95\% CI) & $0.01[-0.17,0.18]$ \\
\hline $34.2 \mathrm{ICH}$ & 2 & 627 & Mean Difference (IV, Random, 95\% CI) & $-0.02[-0.08,0.04]$ \\
\hline $\begin{array}{l}35 \mathrm{EQ} 5 \mathrm{D}-3 \mathrm{~L} \text {, end of trial, } \\
\text { by time to randomisation }\end{array}$ & 4 & 4087 & Mean Difference (IV, Random, 95\% CI) & $0.01[-0.04,0.06]$ \\
\hline $35.1<6$ hours & 2 & 312 & Mean Difference (IV, Random, 95\% CI) & $0.11[0.02,0.20]$ \\
\hline 35.26 .1 to 12 hours & 2 & 435 & Mean Difference (IV, Random, 95\% CI) & $-0.04[-0.12,0.04]$ \\
\hline 35.312 .1 to 24 hours & 2 & 1052 & Mean Difference (IV, Random, 95\% CI) & $-0.01[-0.06,0.04]$ \\
\hline 35.424 .1 to 36 hours & 2 & 1196 & Mean Difference (IV, Random, 95\% CI) & $0.01[-0.04,0.06]$ \\
\hline
\end{tabular}




\begin{tabular}{|c|c|c|c|c|}
\hline $\begin{array}{l}\text { Outcome or subgroup ti- } \\
\text { tle }\end{array}$ & No. of studies & $\begin{array}{l}\text { No. of partici- } \\
\text { pants }\end{array}$ & Statistical method & Effect size \\
\hline $35.5>36$ hours & 3 & 1092 & Mean Difference (IV, Random, 95\% CI) & $-0.10[-0.33,0.13]$ \\
\hline $\begin{array}{l}36 \text { EQ5D-3L, end of trial, } \\
\text { by baseline SBP }\end{array}$ & 4 & 4086 & Mean Difference (IV, Random, 95\% CI) & $0.02[-0.05,0.08]$ \\
\hline $36.1<160 \mathrm{mmHg}$ & 4 & 1664 & Mean Difference (IV, Random, 95\% CI) & $-0.12[-0.34,0.10]$ \\
\hline 36.2160 .1 to $180 \mathrm{mmHg}$ & 4 & 1438 & Mean Difference (IV, Random, 95\% CI) & $0.22[-0.08,0.51]$ \\
\hline 36.3180 .1 to $200 \mathrm{mmHg}$ & 3 & 726 & Mean Difference (IV, Random, 95\% CI) & $-0.01[-0.07,0.05]$ \\
\hline $36.4>200 \mathrm{mmHg}$ & 3 & 258 & Mean Difference (IV, Random, 95\% CI) & $0.08[-0.01,0.18]$ \\
\hline 37 EQ VAS, end of trial & 4 & 3575 & Mean Difference (IV, Random, 95\% CI) & $1.12[-0.91,3.15]$ \\
\hline 37.1 Overall & 4 & 3575 & Mean Difference (IV, Random, 95\% CI) & $1.12[-0.91,3.15]$ \\
\hline $\begin{array}{l}38 \text { EQ VAS, end of trial, by } \\
\text { stroke type }\end{array}$ & 4 & 3523 & Mean Difference (IV, Random, 95\% CI) & $0.92[-1.13,2.96]$ \\
\hline 38.1 Ischaemic & 4 & 2974 & Mean Difference (IV, Random, 95\% CI) & $1.15[-1.06,3.37]$ \\
\hline $38.2 \mathrm{ICH}$ & 2 & 549 & Mean Difference (IV, Random, 95\% CI) & $-0.43[-5.72,4.86]$ \\
\hline $\begin{array}{l}39 \text { EQ VAS, end of trial, by } \\
\text { time to randomisation }\end{array}$ & 4 & 3574 & Mean Difference (IV, Random, 95\% CI) & $1.91[-1.21,5.04]$ \\
\hline $39.1<6$ hours & 2 & 295 & Mean Difference (IV, Random, 95\% CI) & $9.96[2.49,17.43]$ \\
\hline 39.26 .1 to 12 hours & 2 & 392 & Mean Difference (IV, Random, 95\% CI) & $-2.92[-9.45,3.61]$ \\
\hline 39.312 .1 to 24 hours & 2 & 906 & Mean Difference (IV, Random, 95\% CI) & $0.67[-3.42,4.76]$ \\
\hline 39.424 .1 to 36 hours & 3 & 1045 & Mean Difference (IV, Random, 95\% CI) & $-1.56[-5.31,2.18]$ \\
\hline $39.5>36$ hours & 3 & 936 & Mean Difference (IV, Random, 95\% CI) & $4.63[-1.21,10.48]$ \\
\hline $\begin{array}{l}40 \text { EQ VAS, end of trial, by } \\
\text { baseline SBP }\end{array}$ & 4 & 3574 & Mean Difference (IV, Random, 95\% CI) & $0.88[-1.16,2.92]$ \\
\hline $40.1<160 \mathrm{mmHg}$ & 4 & 1480 & Mean Difference (IV, Random, 95\% CI) & $0.41[-2.74,3.57]$ \\
\hline 40.2160 .1 to $180 \mathrm{mmHg}$ & 4 & 1258 & Mean Difference (IV, Random, 95\% CI) & $2.02[-6.59,10.64]$ \\
\hline 40.3180 .1 to $200 \mathrm{mmHg}$ & 4 & 617 & Mean Difference (IV, Random, 95\% CI) & $0.77[-4.21,5.75]$ \\
\hline $40.4>200 \mathrm{mmHg}$ & 3 & 219 & Mean Difference (IV, Random, 95\% CI) & $5.22[-3.55,14.00]$ \\
\hline 41 t-MMSE, end of trial & 3 & 2078 & Mean Difference (IV, Random, 95\% CI) & $1.13[-1.77,4.03]$ \\
\hline 41.1 Overall & 3 & 2078 & Mean Difference (IV, Random, 95\% CI) & $1.13[-1.77,4.03]$ \\
\hline $\begin{array}{l}42 \text { t-MMSE, end of trial, by } \\
\text { stroke type }\end{array}$ & 3 & 2041 & Mean Difference (IV, Random, 95\% CI) & $0.78[-0.90,2.45]$ \\
\hline
\end{tabular}




\begin{tabular}{|c|c|c|c|c|}
\hline $\begin{array}{l}\text { Outcome or subgroup ti- } \\
\text { tle }\end{array}$ & No. of studies & $\begin{array}{l}\text { No. of partici- } \\
\text { pants }\end{array}$ & Statistical method & Effect size \\
\hline 42.1 Ischaemic & 3 & 1729 & Mean Difference (IV, Random, 95\% CI) & $3.15[-3.44,9.74]$ \\
\hline $42.2 \mathrm{ICH}$ & 2 & 312 & Mean Difference (IV, Random, 95\% CI) & $0.15[-1.61,1.91]$ \\
\hline $\begin{array}{l}43 \text { t-MMSE, end of trial, by } \\
\text { time to randomisation }\end{array}$ & 3 & 2078 & Mean Difference (IV, Random, 95\% CI) & $0.69[-0.59,1.97]$ \\
\hline $43.1<6$ hours & 2 & 219 & Mean Difference (IV, Random, 95\% CI) & $3.61[1.68,5.55]$ \\
\hline 43.26 .1 to 12 hours & 2 & 254 & Mean Difference (IV, Random, 95\% CI) & $-1.75[-3.68,0.18]$ \\
\hline 43.312 .1 to -24 hours & 1 & 556 & Mean Difference (IV, Random, 95\% CI) & $0.0[-1.24,1.24]$ \\
\hline 43.424 .1 to 36 hours & 1 & 587 & Mean Difference (IV, Random, 95\% CI) & $0.33[-0.90,1.56]$ \\
\hline $43.5>36$ hours & 2 & 462 & Mean Difference (IV, Random, 95\% CI) & $0.82[-0.58,2.22]$ \\
\hline $\begin{array}{l}44 \text { t-MMSE, end of trial, by } \\
\text { baseline SBP }\end{array}$ & 3 & 2073 & Mean Difference (IV, Random, 95\% CI) & $0.52[-0.46,1.50]$ \\
\hline $44.1<160 \mathrm{mmHg}$ & 2 & 860 & Mean Difference (IV, Random, 95\% CI) & $-0.20[-1.21,0.82]$ \\
\hline 44.2160 .1 to $180 \mathrm{mmHg}$ & 3 & 744 & Mean Difference (IV, Random, 95\% CI) & $4.78[-4.78,14.33]$ \\
\hline 44.3180 .1 to $200 \mathrm{mmHg}$ & 2 & 346 & Mean Difference (IV, Random, 95\% CI) & $0.04[-1.56,1.64]$ \\
\hline $44.4>200 \mathrm{mmHg}$ & 2 & 123 & Mean Difference (IV, Random, 95\% CI) & $1.44[-1.49,4.36]$ \\
\hline 45 TICS, end of trial & 1 & 2013 & Mean Difference (IV, Random, 95\% CI) & $0.30[-0.63,1.23]$ \\
\hline 45.1 Overall & 1 & 2013 & Mean Difference (IV, Random, 95\% CI) & $0.30[-0.63,1.23]$ \\
\hline $\begin{array}{l}46 \text { TICS, end of trial, by } \\
\text { stroke type }\end{array}$ & 1 & 1985 & Mean Difference (IV, Random, 95\% CI) & $0.35[-0.59,1.28]$ \\
\hline 46.1 Ischaemic & 1 & 1683 & Mean Difference (IV, Random, 95\% CI) & $0.42[-0.59,1.43]$ \\
\hline $46.2 \mathrm{ICH}$ & 1 & 302 & Mean Difference (IV, Random, 95\% CI) & $-0.12[-2.65,2.41]$ \\
\hline $\begin{array}{l}47 \text { TICS, end of trial, by } \\
\text { time to randomisation }\end{array}$ & 1 & 2013 & Mean Difference (IV, Random, 95\% CI) & $0.62[-1.33,2.56]$ \\
\hline $47.1<6$ hours & 1 & 182 & Mean Difference (IV, Random, 95\% CI) & $5.59[2.63,8.55]$ \\
\hline 47.26 .1 to 12 hours & 1 & 248 & Mean Difference (IV, Random, 95\% CI) & $-2.19[-4.94,0.56]$ \\
\hline 47.312 .1 to 24 hours & 1 & 549 & Mean Difference (IV, Random, 95\% CI) & $-0.56[-2.32,1.20]$ \\
\hline 47.424 .1 to 36 hours & 1 & 583 & Mean Difference (IV, Random, 95\% CI) & $0.25[-1.46,1.96]$ \\
\hline $47.5>36$ hours & 1 & 451 & Mean Difference (IV, Random, 95\% CI) & $0.66[-1.32,2.64]$ \\
\hline $\begin{array}{l}48 \text { TICS, end of trial, by } \\
\text { baseline SBP }\end{array}$ & 1 & 2013 & Mean Difference (IV, Random, 95\% CI) & $0.30[-0.76,1.37]$ \\
\hline
\end{tabular}




\begin{tabular}{|c|c|c|c|c|}
\hline $\begin{array}{l}\text { Outcome or subgroup ti- } \\
\text { tle }\end{array}$ & No. of studies & $\begin{array}{l}\text { No. of partici- } \\
\text { pants }\end{array}$ & Statistical method & Effect size \\
\hline $48.1<160 \mathrm{mmHg}$ & 1 & 838 & Mean Difference (IV, Random, 95\% CI) & $-0.66[-2.11,0.79]$ \\
\hline 48.2160 .1 to $180 \mathrm{mmHg}$ & 1 & 728 & Mean Difference (IV, Random, 95\% CI) & $1.31[-0.21,2.83]$ \\
\hline 48.3180 .1 to $200 \mathrm{mmHg}$ & 1 & 332 & Mean Difference (IV, Random, 95\% CI) & $0.05[-2.20,2.30]$ \\
\hline $48.4>200 \mathrm{mmHg}$ & 1 & 115 & Mean Difference (IV, Random, 95\% CI) & $1.32[-1.00,5.64]$ \\
\hline $\begin{array}{l}49 \text { Animal naming, end of } \\
\text { trial }\end{array}$ & 1 & 2366 & Mean Difference (IV, Random, 95\% CI) & $0.10[-0.53,0.73]$ \\
\hline 49.1 Overall & 1 & 2366 & Mean Difference (IV, Random, 95\% CI) & $0.10[-0.53,0.73]$ \\
\hline $\begin{array}{l}50 \text { Animal naming, end of } \\
\text { trial, by stroke type }\end{array}$ & 1 & 2336 & Mean Difference (IV, Random, 95\% CI) & $0.12[-0.51,0.75]$ \\
\hline 50.1 Ischaemic & 1 & 1960 & Mean Difference (IV, Random, 95\% CI) & $0.09[-0.60,0.78]$ \\
\hline $50.2 \mathrm{ICH}$ & 1 & 376 & Mean Difference (IV, Random, 95\% CI) & $0.28[-1.25,1.81]$ \\
\hline $\begin{array}{l}51 \text { Animal naming, end of } \\
\text { trial, by time to randomi- } \\
\text { sation }\end{array}$ & 1 & 2366 & Mean Difference (IV, Random, 95\% CI) & $0.25[-0.80,1.30]$ \\
\hline $51.1<6$ hours & 1 & 192 & Mean Difference (IV, Random, 95\% CI) & $2.94[0.88,5.00]$ \\
\hline 51.26 .1 to 12 hours & 1 & 286 & Mean Difference (IV, Random, 95\% CI) & $-1.33[-3.26,0.60]$ \\
\hline 51.312 .1 to 24 hours & 1 & 625 & Mean Difference (IV, Random, 95\% CI) & $0.02[-1.21,1.25]$ \\
\hline 51.424 .1 to 36 hours & 1 & 695 & Mean Difference (IV, Random, 95\% CI) & $-0.34[-1.48,0.80]$ \\
\hline $51.5>36$ hours & 1 & 568 & Mean Difference (IV, Random, 95\% CI) & $0.48[-0.82,1.78]$ \\
\hline $\begin{array}{l}52 \text { Animal naming, end of } \\
\text { trial, by baseline SBP }\end{array}$ & 1 & 2366 & Mean Difference (IV, Random, 95\% CI) & $0.10[-0.53,0.73]$ \\
\hline $52.1<160 \mathrm{mmHg}$ & 1 & 966 & Mean Difference (IV, Random, 95\% CI) & $-0.36[-1.36,0.64]$ \\
\hline 52.2160 .1 to $180 \mathrm{mmHg}$ & 1 & 850 & Mean Difference (IV, Random, 95\% CI) & $0.40[-0.64,1.44]$ \\
\hline 52.3180 .1 to $200 \mathrm{mmHg}$ & 1 & 410 & Mean Difference (IV, Random, 95\% CI) & $0.26[-1.25,1.77]$ \\
\hline $52.4>200 \mathrm{mmHg}$ & 1 & 140 & Mean Difference (IV, Random, 95\% CI) & $0.92[-1.69,3.53]$ \\
\hline 53 Physiotherapy & 3 & 4042 & Odds Ratio (M-H, Random, 95\% Cl) & $0.94[0.79,1.12]$ \\
\hline 53.1 Overall & 3 & 4042 & Odds Ratio (M-H, Random, 95\% Cl) & $0.94[0.79,1.12]$ \\
\hline $\begin{array}{l}54 \text { Physiotherapy, by } \\
\text { stroke type }\end{array}$ & 3 & 3994 & Odds Ratio (M-H, Random, 95\% Cl) & $0.96[0.80,1.15]$ \\
\hline 54.1 Ischaemic & 3 & 3363 & Odds Ratio (M-H, Random, 95\% Cl) & $0.91[0.74,1.11]$ \\
\hline
\end{tabular}




\begin{tabular}{|c|c|c|c|c|}
\hline $\begin{array}{l}\text { Outcome or subgroup ti- } \\
\text { tle }\end{array}$ & No. of studies & $\begin{array}{l}\text { No. of partici- } \\
\text { pants }\end{array}$ & Statistical method & Effect size \\
\hline $54.2 \mathrm{ICH}$ & 3 & 631 & Odds Ratio (M-H, Random, 95\% Cl) & $1.16[0.79,1.70]$ \\
\hline $\begin{array}{l}55 \text { Physiotherapy, by time } \\
\text { to randomisation }\end{array}$ & 3 & 4041 & Odds Ratio (M-H, Random, 95\% Cl) & $0.96[0.80,1.15]$ \\
\hline $55.1<6$ hours & 2 & 307 & Odds Ratio (M-H, Random, 95\% Cl) & $0.90[0.40,2.05]$ \\
\hline 55.26 .1 to 12 hours & 2 & 439 & Odds Ratio (M-H, Random, 95\% Cl) & $0.87[0.56,1.36]$ \\
\hline 55.312 .1 to 24 hours & 1 & 1064 & Odds Ratio (M-H, Random, 95\% Cl) & $1.08[0.77,1.51]$ \\
\hline 55.424 .1 to 36 hours & 2 & 1198 & Odds Ratio (M-H, Random, 95\% Cl) & $1.07[0.76,1.49]$ \\
\hline $55.5>36$ hours & 2 & 1033 & Odds Ratio (M-H, Random, 95\% Cl) & $0.83[0.54,1.27]$ \\
\hline $\begin{array}{l}56 \text { Physiotherapy, by base- } \\
\text { line SBP }\end{array}$ & 3 & 4042 & Odds Ratio (M-H, Random, 95\% Cl) & $0.94[0.78,1.13]$ \\
\hline $56.1<160 \mathrm{mmHg}$ & 3 & 1624 & Odds Ratio (M-H, Random, 95\% Cl) & $1.00[0.75,1.32]$ \\
\hline 56.2160 .1 to $180 \mathrm{mmHg}$ & 3 & 1433 & Odds Ratio (M-H, Random, 95\% Cl) & $0.89[0.46,1.72]$ \\
\hline 56.3180 .1 to $200 \mathrm{mmHg}$ & 3 & 730 & Odds Ratio (M-H, Random, 95\% Cl) & $0.68[0.44,1.04]$ \\
\hline $56.4>200 \mathrm{mmHg}$ & 2 & 255 & Odds Ratio (M-H, Random, 95\% Cl) & $1.80[0.54,5.98]$ \\
\hline 57 Occupational therapy & 3 & 4042 & Odds Ratio (M-H, Random, 95\% Cl) & $1.01[0.72,1.41]$ \\
\hline 57.1 Overall & 3 & 4042 & Odds Ratio (M-H, Random, 95\% Cl) & $1.01[0.72,1.41]$ \\
\hline $\begin{array}{l}58 \text { Occupational therapy, } \\
\text { by stroke type }\end{array}$ & 3 & 3994 & Odds Ratio (M-H, Random, 95\% Cl) & $1.02[0.84,1.24]$ \\
\hline 58.1 Ischaemic & 3 & 3363 & Odds Ratio (M-H, Random, 95\% Cl) & $0.93[0.81,1.08]$ \\
\hline $58.2 \mathrm{ICH}$ & 3 & 631 & Odds Ratio (M-H, Random, 95\% Cl) & $1.26[0.92,1.73]$ \\
\hline $\begin{array}{l}59 \text { Occupational therapy, } \\
\text { by time to randomisation }\end{array}$ & 3 & 4041 & Odds Ratio (M-H, Random, 95\% Cl) & $0.99[0.86,1.13]$ \\
\hline $59.1<6$ hours & 2 & 307 & Odds Ratio (M-H, Random, 95\% Cl) & $1.15[0.36,3.68]$ \\
\hline 59.26 .1 to 12 hours & 2 & 439 & Odds Ratio (M-H, Random, 95\% Cl) & $0.94[0.65,1.37]$ \\
\hline 59.312 .1 to 24 hours & 1 & 1064 & Odds Ratio (M-H, Random, 95\% Cl) & $1.06[0.82,1.36]$ \\
\hline 59.424 .1 to 36 hours & 2 & 1198 & Odds Ratio (M-H, Random, 95\% Cl) & $1.00[0.79,1.28]$ \\
\hline $59.5>36$ hours & 2 & 1033 & Odds Ratio (M-H, Random, 95\% Cl) & $0.96[0.72,1.28]$ \\
\hline $\begin{array}{l}60 \text { Occupational therapy, } \\
\text { by baseline SBP }\end{array}$ & 3 & 4042 & Odds Ratio (M-H, Random, 95\% Cl) & $1.03[0.81,1.30]$ \\
\hline $60.1<160 \mathrm{mmHg}$ & 3 & 1624 & Odds Ratio (M-H, Random, 95\% Cl) & $1.00[0.81,1.23]$ \\
\hline
\end{tabular}




\begin{tabular}{|c|c|c|c|c|}
\hline $\begin{array}{l}\text { Outcome or subgroup ti- } \\
\text { tle }\end{array}$ & No. of studies & $\begin{array}{l}\text { No. of partici- } \\
\text { pants }\end{array}$ & Statistical method & Effect size \\
\hline 60.2160 .1 to $180 \mathrm{mmHg}$ & 3 & 1433 & Odds Ratio (M-H, Random, 95\% Cl) & $0.94[0.76,1.17]$ \\
\hline 60.3180 .1 to $200 \mathrm{mmHg}$ & 3 & 730 & Odds Ratio (M-H, Random, 95\% Cl) & $0.74[0.54,1.00]$ \\
\hline $60.4>200 \mathrm{mmHg}$ & 2 & 255 & Odds Ratio (M-H, Random, 95\% Cl) & $2.11[1.25,3.54]$ \\
\hline $\begin{array}{l}61 \text { Speech and language } \\
\text { therapy }\end{array}$ & 3 & 4042 & Odds Ratio (M-H, Random, 95\% Cl) & $0.95[0.84,1.08]$ \\
\hline 61.1 Overall & 3 & 4042 & Odds Ratio (M-H, Random, 95\% Cl) & $0.95[0.84,1.08]$ \\
\hline $\begin{array}{l}62 \text { Speech and language } \\
\text { therapy, by stroke type }\end{array}$ & 3 & 3994 & Odds Ratio (M-H, Random, 95\% Cl) & $0.97[0.85,1.09]$ \\
\hline 62.1 Ischaemic & 3 & 3363 & Odds Ratio (M-H, Random, 95\% Cl) & $0.94[0.82,1.08]$ \\
\hline $62.2 \mathrm{ICH}$ & 3 & 631 & Odds Ratio (M-H, Random, 95\% Cl) & $0.76[0.14,4.19]$ \\
\hline $\begin{array}{l}63 \text { Speech and language } \\
\text { therapy, by time to ran- } \\
\text { domisation }\end{array}$ & 3 & 4041 & Odds Ratio (M-H, Random, 95\% Cl) & $0.96[0.85,1.09]$ \\
\hline $63.1<6$ hours & 2 & 307 & Odds Ratio (M-H, Random, 95\% Cl) & $1.01[0.44,2.29]$ \\
\hline 63.26 .1 to 12 hours & 2 & 439 & Odds Ratio (M-H, Random, 95\% Cl) & $0.95[0.64,1.40]$ \\
\hline 63.312 .1 to 24 hours & 1 & 1064 & Odds Ratio (M-H, Random, 95\% Cl) & $0.95[0.75,1.21]$ \\
\hline 63.424 .1 to 36 hours & 2 & 1198 & Odds Ratio (M-H, Random, 95\% Cl) & $0.96[0.76,1.20]$ \\
\hline $63.5>36$ hours & 2 & 1033 & Odds Ratio (M-H, Random, 95\% Cl) & $1.01[0.79,1.29]$ \\
\hline $\begin{array}{l}64 \text { Speech and language } \\
\text { therapy, by baseline SBP }\end{array}$ & 3 & 4042 & Odds Ratio (M-H, Random, 95\% Cl) & $0.95[0.84,1.08]$ \\
\hline $64.1<160 \mathrm{mmHg}$ & 3 & 1624 & Odds Ratio (M-H, Random, 95\% Cl) & $0.98[0.58,1.66]$ \\
\hline 64.2160 .1 to $180 \mathrm{mmHg}$ & 3 & 1433 & Odds Ratio (M-H, Random, 95\% Cl) & $0.94[0.76,1.16]$ \\
\hline 64.3180 .1 to $200 \mathrm{mmHg}$ & 3 & 730 & Odds Ratio (M-H, Random, 95\% Cl) & $1.00[0.75,1.34]$ \\
\hline $64.4>200 \mathrm{mmHg}$ & 2 & 255 & Odds Ratio (M-H, Random, 95\% Cl) & $1.38[0.84,2.26]$ \\
\hline $\begin{array}{l}65 \text { Feeding route (non-oral } \\
\text { feeding at day } 7 \text { ) }\end{array}$ & 3 & 4009 & Odds Ratio (M-H, Random, 95\% Cl) & $0.97[0.82,1.15]$ \\
\hline 65.1 Overall & 3 & 4009 & Odds Ratio (M-H, Random, 95\% Cl) & $0.97[0.82,1.15]$ \\
\hline $\begin{array}{l}66 \text { Feeding route (non-oral } \\
\text { feeding at day } 7 \text { ), by stroke } \\
\text { type }\end{array}$ & 3 & 3962 & Odds Ratio (M-H, Random, 95\% Cl) & $0.99[0.80,1.22]$ \\
\hline 66.1 Ischaemic & 3 & 3339 & Odds Ratio (M-H, Random, 95\% Cl) & $0.90[0.75,1.09]$ \\
\hline
\end{tabular}




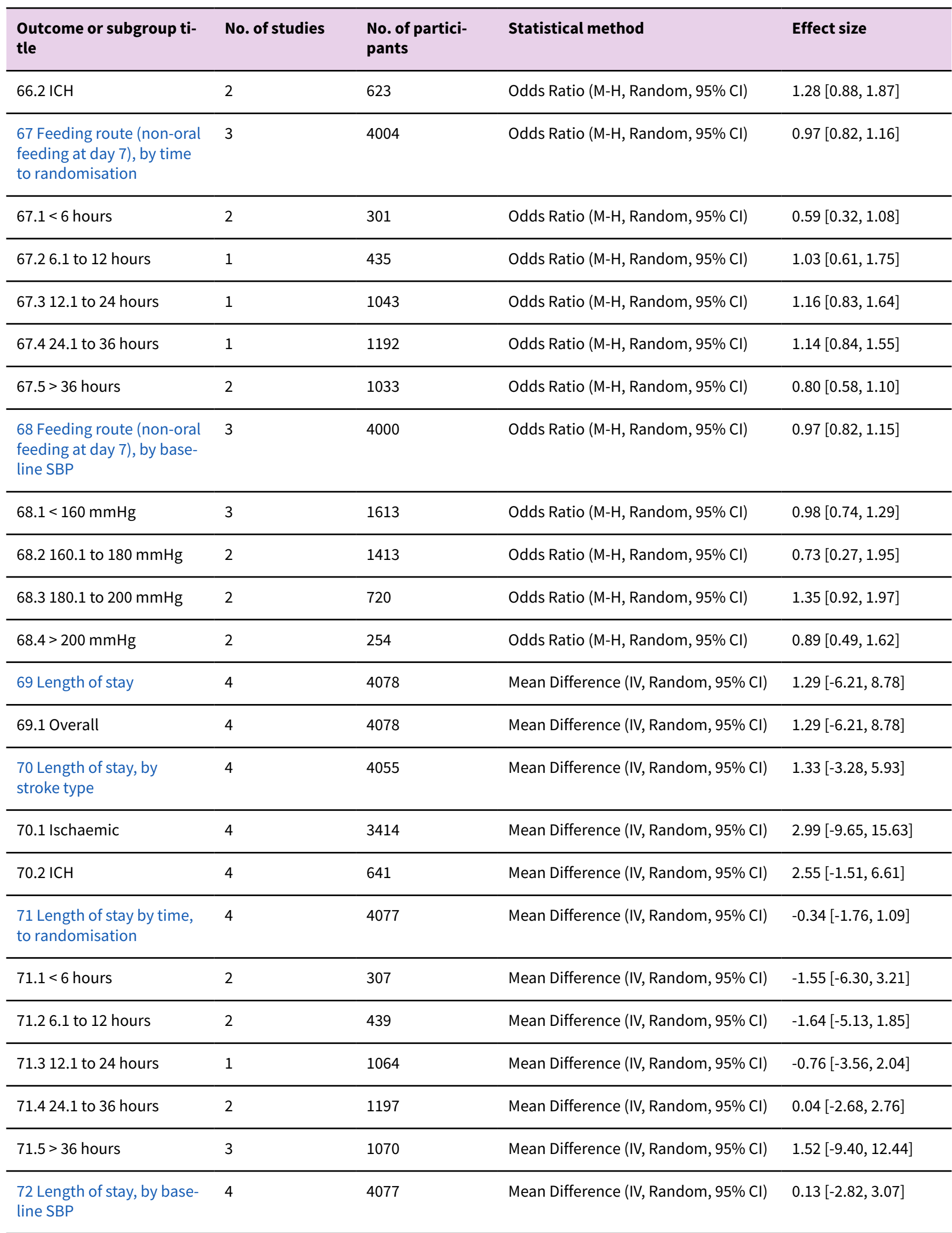




\begin{tabular}{|c|c|c|c|c|}
\hline $\begin{array}{l}\text { Outcome or subgroup ti- } \\
\text { tle }\end{array}$ & No. of studies & $\begin{array}{l}\text { No. of partici- } \\
\text { pants }\end{array}$ & Statistical method & Effect size \\
\hline $72.1<160 \mathrm{mmHg}$ & 4 & 1644 & Mean Difference (IV, Random, 95\% CI) & $8.63[-8.44,25.71]$ \\
\hline 72.2160 .1 to $180 \mathrm{mmHg}$ & 4 & 1443 & Mean Difference (IV, Random, 95\% CI) & $-3.77[-18.94,11.40]$ \\
\hline 72.3180 .1 to $200 \mathrm{mmHg}$ & 4 & 733 & Mean Difference (IV, Random, 95\% CI) & $-1.17[-4.86,2.51]$ \\
\hline $72.4>200 \mathrm{mmHg}$ & 3 & 257 & Mean Difference (IV, Random, 95\% CI) & $4.50[-2.45,11.45]$ \\
\hline $\begin{array}{l}73 \text { Headache, on treat- } \\
\text { ment }\end{array}$ & 5 & 4186 & Odds Ratio (M-H, Random, 95\% Cl) & $2.37[1.55,3.62]$ \\
\hline 73.1 Overall & 5 & 4186 & Odds Ratio (M-H, Random, 95\% Cl) & $2.37[1.55,3.62]$ \\
\hline $\begin{array}{l}74 \text { Headache, on treat- } \\
\text { ment, by stroke type }\end{array}$ & 4 & 4048 & Odds Ratio (M-H, Random, 95\% Cl) & $2.34[1.93,2.84]$ \\
\hline 74.1 Ischaemic & 4 & 3409 & Odds Ratio (M-H, Random, 95\% Cl) & $2.39[1.59,3.61]$ \\
\hline $74.2 \mathrm{ICH}$ & 4 & 639 & Odds Ratio (M-H, Random, 95\% Cl) & $1.91[1.24,2.93]$ \\
\hline $\begin{array}{l}75 \text { Headache, on treat- } \\
\text { ment, by time to randomi- } \\
\text { sation }\end{array}$ & 4 & 4094 & Odds Ratio (M-H, Random, 95\% Cl) & $2.36[1.95,2.86]$ \\
\hline $75.1<6$ hours & 2 & 309 & Odds Ratio (M-H, Random, 95\% Cl) & $2.22[1.10,4.45]$ \\
\hline 75.26 .1 to 12 hours & 2 & 440 & Odds Ratio (M-H, Random, 95\% Cl) & $2.08[1.16,3.73]$ \\
\hline 75.312 .1 to 24 hours & 1 & 1065 & Odds Ratio (M-H, Random, 95\% Cl) & $2.57[1.78,3.71]$ \\
\hline 75.424 .1 to 36 hours & 2 & 1202 & Odds Ratio (M-H, Random, 95\% Cl) & $2.27[1.59,3.22]$ \\
\hline $75.5>36$ hours & 3 & 1078 & Odds Ratio (M-H, Random, 95\% Cl) & $2.42[1.64,3.58]$ \\
\hline $\begin{array}{l}76 \text { Headache, on treat- } \\
\text { ment, by baseline SBP }\end{array}$ & 4 & 4095 & Odds Ratio (M-H, Random, 95\% Cl) & $2.29[1.83,2.86]$ \\
\hline $76.1<160 \mathrm{mmHg}$ & 4 & 1649 & Odds Ratio (M-H, Random, 95\% Cl) & $2.37[1.74,3.21]$ \\
\hline 76.2160 .1 to $180 \mathrm{mmHg}$ & 4 & 1453 & Odds Ratio (M-H, Random, 95\% Cl) & $2.97[2.14,4.12]$ \\
\hline 76.3180 .1 to $200 \mathrm{mmHg}$ & 4 & 736 & Odds Ratio (M-H, Random, 95\% Cl) & $1.42[0.92,2.18]$ \\
\hline $76.4>200 \mathrm{mmHg}$ & 3 & 257 & Odds Ratio (M-H, Random, 95\% Cl) & $1.25[0.08,20.46]$ \\
\hline $\begin{array}{l}77 \text { Treatment stopped ear- } \\
\text { ly }\end{array}$ & 5 & 4193 & Odds Ratio (M-H, Random, 95\% Cl) & $1.84[0.27,12.42]$ \\
\hline 77.1 Overall & 5 & 4193 & Odds Ratio (M-H, Random, 95\% Cl) & $1.84[0.27,12.42]$ \\
\hline $\begin{array}{l}78 \text { Treatment stopped ear- } \\
\text { ly, by stroke type }\end{array}$ & 4 & 4102 & Odds Ratio (M-H, Random, 95\% Cl) & $2.49[0.72,8.59]$ \\
\hline 78.1 Ischaemic & 4 & 3465 & Odds Ratio (M-H, Random, 95\% Cl) & $1.26[0.07,21.87]$ \\
\hline
\end{tabular}




\begin{tabular}{|c|c|c|c|c|}
\hline $\begin{array}{l}\text { Outcome or subgroup ti- } \\
\text { tle }\end{array}$ & No. of studies & $\begin{array}{l}\text { No. of partici- } \\
\text { pants }\end{array}$ & Statistical method & Effect size \\
\hline $78.2 \mathrm{ICH}$ & 3 & 637 & Odds Ratio (M-H, Random, 95\% Cl) & $6.81[3.46,13.43]$ \\
\hline $\begin{array}{l}79 \text { Treatment stopped ear- } \\
\text { ly, by time to randomisa- } \\
\text { tion }\end{array}$ & 5 & 4192 & Odds Ratio (M-H, Random, 95\% Cl) & $4.56[2.10,9.87]$ \\
\hline $79.1<6$ hours & 2 & 312 & Odds Ratio (M-H, Random, 95\% Cl) & $1.03[0.05,22.27]$ \\
\hline 79.26 .1 to 12 hours & 2 & 440 & Odds Ratio (M-H, Random, 95\% Cl) & $12.12[4.26,34.44]$ \\
\hline 79.312 .1 to 24 hours & 2 & 1070 & Odds Ratio (M-H, Random, 95\% Cl) & $6.42[4.07,10.12]$ \\
\hline 79.424 .1 to 36 hours & 3 & 1218 & Odds Ratio (M-H, Random, 95\% Cl) & $9.23[1.63,52.33]$ \\
\hline $79.5>36$ hours & 4 & 1152 & Odds Ratio (M-H, Random, 95\% Cl) & $3.86[0.58,25.79]$ \\
\hline $\begin{array}{l}80 \text { Treatment stopped ear- } \\
\text { ly, by baseline SBP }\end{array}$ & 4 & 4159 & Odds Ratio (M-H, Random, 95\% Cl) & $2.84[1.37,5.88]$ \\
\hline $80.1<160 \mathrm{mmHg}$ & 4 & 1687 & Odds Ratio (M-H, Random, 95\% Cl) & $1.33[0.09,20.26]$ \\
\hline 80.2160 .1 to $180 \mathrm{mmHg}$ & 4 & 1467 & Odds Ratio (M-H, Random, 95\% Cl) & $2.17[0.17,27.08]$ \\
\hline 80.3180 .1 to $200 \mathrm{mmHg}$ & 4 & 742 & Odds Ratio (M-H, Random, 95\% Cl) & $1.38[0.17,11.13]$ \\
\hline $80.4>200 \mathrm{mmHg}$ & 3 & 263 & Odds Ratio (M-H, Random, 95\% Cl) & $2.16[0.21,22.44]$ \\
\hline $\begin{array}{l}81 \text { Systolic BP, first treat- } \\
\text { ment measurement }\end{array}$ & 5 & 4197 & Mean Difference (IV, Fixed, 95\% CI) & $-7.21[-8.58,-5.85]$ \\
\hline 81.1 Overall & 5 & 4197 & Mean Difference (IV, Fixed, 95\% CI) & $-7.21[-8.58,-5.85]$ \\
\hline $\begin{array}{l}82 \text { Systolic BP, first treat- } \\
\text { ment measurement, by } \\
\text { stroke type }\end{array}$ & 5 & 4143 & Mean Difference (IV, Fixed, 95\% CI) & $-7.01[-8.37,-5.66]$ \\
\hline 82.1 Ischaemic & 5 & 3502 & Mean Difference (IV, Fixed, 95\% CI) & $-7.05[-8.51,-5.59]$ \\
\hline $82.2 \mathrm{ICH}$ & 4 & 641 & Mean Difference (IV, Fixed, 95\% CI) & $-6.77[-10.45,-3.09]$ \\
\hline $\begin{array}{l}83 \text { Systolic BP, first treat- } \\
\text { ment measurement, by } \\
\text { time to randomisation }\end{array}$ & 5 & 4195 & Mean Difference (IV, Fixed, 95\% CI) & $-7.21[-8.57,-5.84]$ \\
\hline $83.1<6$ hours & 2 & 312 & Mean Difference (IV, Fixed, 95\% CI) & $-9.52[-14.28,-4.75]$ \\
\hline 83.26 .1 to 12 hours & 2 & 440 & Mean Difference (IV, Fixed, 95\% CI) & $-7.92[-12.18,-3.66]$ \\
\hline 83.312 .1 to 24 hours & 2 & 1070 & Mean Difference (IV, Fixed, 95\% CI) & $-5.33[-8.07,-2.59]$ \\
\hline 83.424 .1 to 36 hours & 3 & 1218 & Mean Difference (IV, Fixed, 95\% CI) & $-7.17[-9.66,-4.68]$ \\
\hline $83.5>36$ hours & 4 & 1155 & Mean Difference (IV, Fixed, 95\% CI) & $-8.02[-10.66,-5.37]$ \\
\hline
\end{tabular}




\begin{tabular}{|c|c|c|c|c|}
\hline $\begin{array}{l}\text { Outcome or subgroup ti- } \\
\text { tle }\end{array}$ & No. of studies & $\begin{array}{l}\text { No. of partici- } \\
\text { pants }\end{array}$ & Statistical method & Effect size \\
\hline $\begin{array}{l}84 \text { Diastolic BP, first treat- } \\
\text { ment measurement }\end{array}$ & 5 & 4197 & Mean Difference (IV, Fixed, 95\% CI) & $-3.31[-4.18,-2.45]$ \\
\hline 84.1 Overall & 5 & 4197 & Mean Difference (IV, Fixed, 95\% CI) & $-3.31[-4.18,-2.45]$ \\
\hline $\begin{array}{l}85 \text { Diastolic BP, first treat- } \\
\text { ment measurement, by } \\
\text { stroke type }\end{array}$ & 5 & 4143 & Mean Difference (IV, Fixed, 95\% CI) & $-3.24[-4.10,-2.38]$ \\
\hline 85.1 Ischaemic & 5 & 3502 & Mean Difference (IV, Fixed, 95\% CI) & $-3.13[-4.05,-2.21]$ \\
\hline $85.2 \mathrm{ICH}$ & 4 & 641 & Mean Difference (IV, Fixed, 95\% CI) & $-3.96[-6.36,-1.55]$ \\
\hline $\begin{array}{l}86 \text { Diastolic BP, first treat- } \\
\text { ment measurement, by } \\
\text { time to randomisation }\end{array}$ & 5 & 4195 & Mean Difference (IV, Fixed, 95\% CI) & $-3.31[-4.17,-2.45]$ \\
\hline $86.1<6$ hours & 2 & 312 & Mean Difference (IV, Fixed, 95\% CI) & $-2.31[-5.53,0.90]$ \\
\hline 86.26 .1 to 12 hours & 2 & 440 & Mean Difference (IV, Fixed, 95\% CI) & $-4.5[-7.27,-1.73]$ \\
\hline 86.312 .1 to 24 hours & 2 & 1070 & Mean Difference (IV, Fixed, 95\% CI) & $-3.33[-3.00,-1.66]$ \\
\hline 86.424 .1 to 36 hours & 3 & 1218 & Mean Difference (IV, Fixed, 95\% CI) & $-1.90[-3.49,-0.30]$ \\
\hline $86.5>36$ hours & 4 & 1155 & Mean Difference (IV, Fixed, 95\% CI) & $-4.68[-6.35,-3.01]$ \\
\hline $\begin{array}{l}87 \text { Heart rate, first treat- } \\
\text { ment measurement }\end{array}$ & 5 & 4197 & Mean Difference (IV, Fixed, 95\% CI) & $2.02[1.13,2.91]$ \\
\hline 87.1 Overall & 5 & 4197 & Mean Difference (IV, Fixed, 95\% CI) & $2.02[1.13,2.91]$ \\
\hline $\begin{array}{l}88 \text { Heart rate, first treat- } \\
\text { ment measurement, by } \\
\text { stroke type }\end{array}$ & 5 & 4143 & Mean Difference (IV, Fixed, 95\% CI) & $2.18[1.29,3.08]$ \\
\hline 88.1 Ischaemic & 5 & 3502 & Mean Difference (IV, Fixed, 95\% CI) & $2.12[1.14,3.09]$ \\
\hline $88.2 \mathrm{ICH}$ & 4 & 641 & Mean Difference (IV, Fixed, 95\% CI) & $2.56[0.25,4.88]$ \\
\hline $\begin{array}{l}89 \text { Heart rate, first treat- } \\
\text { ment measurement, by } \\
\text { time to randomisation }\end{array}$ & 5 & 4195 & Mean Difference (IV, Fixed, 95\% CI) & $1.91[1.02,2.80]$ \\
\hline $89.1<6$ hours & 2 & 312 & Mean Difference (IV, Fixed, 95\% CI) & $1.89[-1.62,5.40]$ \\
\hline 89.26 .1 to 12 hours & 2 & 440 & Mean Difference (IV, Fixed, 95\% CI) & $-0.13[-3.16,2.90]$ \\
\hline 89.312 .1 to 24 hours & 2 & 1070 & Mean Difference (IV, Fixed, 95\% CI) & $1.69[-0.11,3.49]$ \\
\hline 89.424 .1 to 36 hours & 3 & 1218 & Mean Difference (IV, Fixed, 95\% CI) & $3.44[1.79,5.09]$ \\
\hline $89.5>36$ hours & 4 & 1155 & Mean Difference (IV, Fixed, 95\% CI) & $1.23[-0.36,2.82]$ \\
\hline
\end{tabular}


Analysis 1.1. Comparison 1 Glyceryl trinitrate (GTN) compared with no GTN for acute stroke, Outcome 1 Death or dependency (mRS>2), end of trial.

\begin{tabular}{|c|c|c|c|c|c|}
\hline Study or subgroup & $\begin{array}{c}\text { NO donor } \\
\mathrm{n} / \mathrm{N}\end{array}$ & $\begin{array}{c}\text { Control } \\
\mathrm{n} / \mathrm{N}\end{array}$ & $\begin{array}{c}\text { Odds Ratio } \\
\text { M-H, Random, } 95 \% \text { Cl }\end{array}$ & Weight & $\begin{array}{c}\text { Odds Ratio } \\
\text { M-H, Random, } 95 \% \text { Cl }\end{array}$ \\
\hline \multicolumn{6}{|l|}{ 1.1.1 Overall } \\
\hline Ankolekar 2013 & $13 / 25$ & $12 / 16$ & 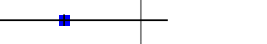 & $0.81 \%$ & $0.36[0.09,1.43]$ \\
\hline Bath 2001 & $10 / 16$ & $8 / 19$ & & $0.83 \%$ & $2.29[0.59,8.94]$ \\
\hline ENOS 2015 & $1205 / 2000$ & $1227 / 2011$ & & $96.11 \%$ & $0.97[0.85,1.1]$ \\
\hline Rashid 2002 & $37 / 60$ & $19 / 30$ & & $1.88 \%$ & $0.93[0.38,2.31]$ \\
\hline Subtotal $(95 \% \mathrm{Cl})$ & 2113 & 2082 & 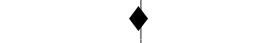 & $100 \%$ & $0.97[0.86,1.1]$ \\
\hline \multicolumn{6}{|c|}{ Total events: 1270 (NO donor), 1268 (Control) } \\
\hline \multicolumn{6}{|c|}{ Heterogeneity: $\operatorname{Tau}^{2}=0 ; \mathrm{Chi}^{2}=3.65, \mathrm{df}=4(\mathrm{P}=0.45) ; \mathrm{I}^{2}=0 \%$} \\
\hline \multicolumn{6}{|c|}{ Test for overall effect: $Z=0.51(P=0.61)$} \\
\hline Total $(95 \% \mathrm{Cl})$ & 2113 & 2082 & 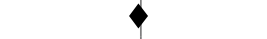 & $100 \%$ & $0.97[0.86,1.1]$ \\
\hline \multicolumn{6}{|c|}{ Heterogeneity: $\mathrm{Tau}^{2}=0 ; \mathrm{Chi}^{2}=3.65, \mathrm{df}=4(\mathrm{P}=0.45) ; \mathrm{I}^{2}=0 \%$} \\
\hline Test for overall effect & & & & & \\
\hline
\end{tabular}

Analysis 1.2. Comparison 1 Glyceryl trinitrate (GTN) compared with no GTN for acute stroke, Outcome 2 Death or dependency (mRS>2), end of trial, by stroke type.

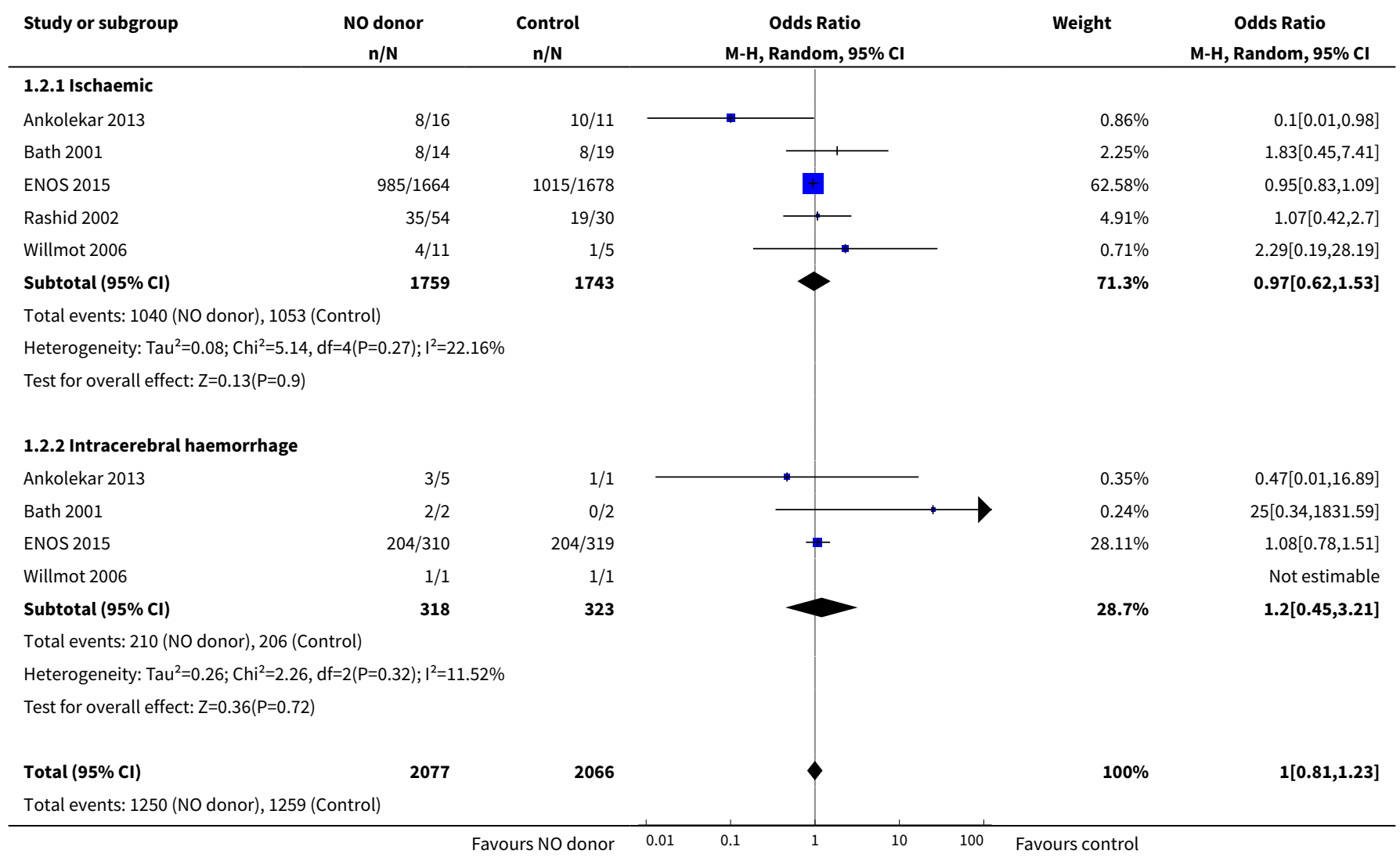




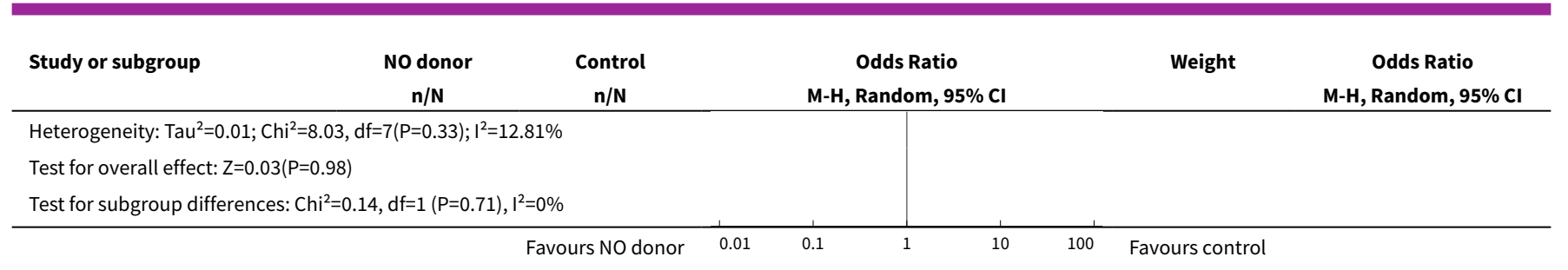

Analysis 1.3. Comparison 1 Glyceryl trinitrate (GTN) compared with no GTN for acute
stroke, Outcome 3 Death or dependency (mRS>2), end of trial, by time to randomisation.

Study or subgroup

NO donor

$n / N$

Control

$n / N$

Odds Ratio

M-H, Random, 95\% Cl

\subsection{1 $<6$ hours}

Ankolekar 2013

ENOS 2015

Subtotal $(95 \% \mathrm{Cl})$

$12 / 24$

$74 / 144$

168

Total events: 86 (NO donor), 89 (Control)

Heterogeneity: $\mathrm{Tau}^{2}=0 ; \mathrm{Chi}^{2}=0.73, \mathrm{df}=1(\mathrm{P}=0.39) ; \mathrm{I}^{2}=0 \%$

Test for overall effect: $Z=1.89(P=0.06)$

\subsubsection{1 to 12 hours}

Ankolekar 2013

ENOS 2015

$1 / 1$

Subtotal $(95 \% \mathrm{Cl})$

Total events: 136 (NO donor), 120 (Control)

Heterogeneity: Not applicable

Test for overall effect: $Z=0.99(P=0.32)$

\subsubsection{1 to 24 hours}

ENOS 2015

Rashid 2002

$320 / 541$

Subtotal $(95 \% \mathrm{Cl})$

542

Total events: 321 (NO donor), 316 (Control)

Heterogeneity: $\mathrm{Tau}^{2}=0 ; \mathrm{Chi}^{2}=0.32, \mathrm{df}=1(\mathrm{P}=0.57) ; \mathrm{I}^{2}=0 \%$

Test for overall effect: $Z=0.21(P=0.83)$

\subsubsection{1 to 36 hours}

ENOS 2015

Rashid 2002

Willmot 2006

Subtotal $(95 \% \mathrm{CI})$

Total events: 388 (NO donor), 388 (Control)

Heterogeneity: $\mathrm{Tau}^{2}=0 ; \mathrm{Chi}^{2}=0.87, \mathrm{df}=2(\mathrm{P}=0.65) ; \mathrm{I}^{2}=0 \%$

Test for overall effect: $Z=0.4(P=0.69)$

\subsection{5 $>36$ hours}

Bath 2001

ENOS 2015

Rashid 2002

Willmot 2006

Subtotal $(95 \% \mathrm{CI})$

$11 / 15$
$78 / 129$
$\mathbf{1 4 4}$

$\begin{array}{rr}10 / 16 & 8 / 19 \\ 296 / 498 & 330 / 532 \\ 29 / 50 & 15 / 24 \\ 4 / 11 & 2 / 4 \\ \mathbf{5 7 5} & \mathbf{5 7 9}\end{array}$

$/ 19$

$315 / 526$

$1 / 2$

528

Odds Ratio

M-H, Random, 95\% Cl

$\begin{array}{rr}0.79 \% & 0.36[0.09,1.47] \\ 6.7 \% & 0.69[0.43,1.12] \\ \mathbf{7 . 4 9 \%} & \mathbf{0 . 6 5 [ 0 . 4 1 , 1 . 0 2}]\end{array}$

Not estimable

$1.21[0.83,1.77]$

$10.73 \%$

$1.21[0.83,1.77]$

Favours NO donor

$1.04[0.82,1.32]$

$1.17[0.07,18.35]$

$9[0.1,831.78]$

$1.05[0.83,1.33]$ 


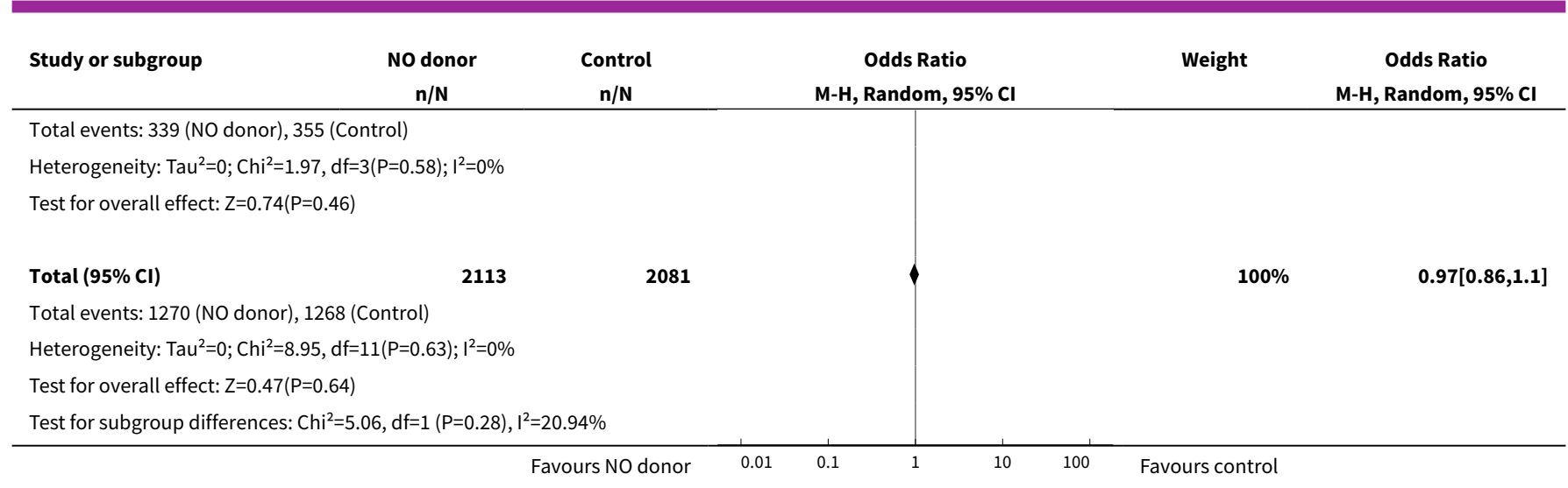

Analysis 1.4. Comparison 1 Glyceryl trinitrate (GTN) compared with no GTN for acute stroke, Outcome 4 Death or dependency (mRS>2), end of trial, by baseline SBP.

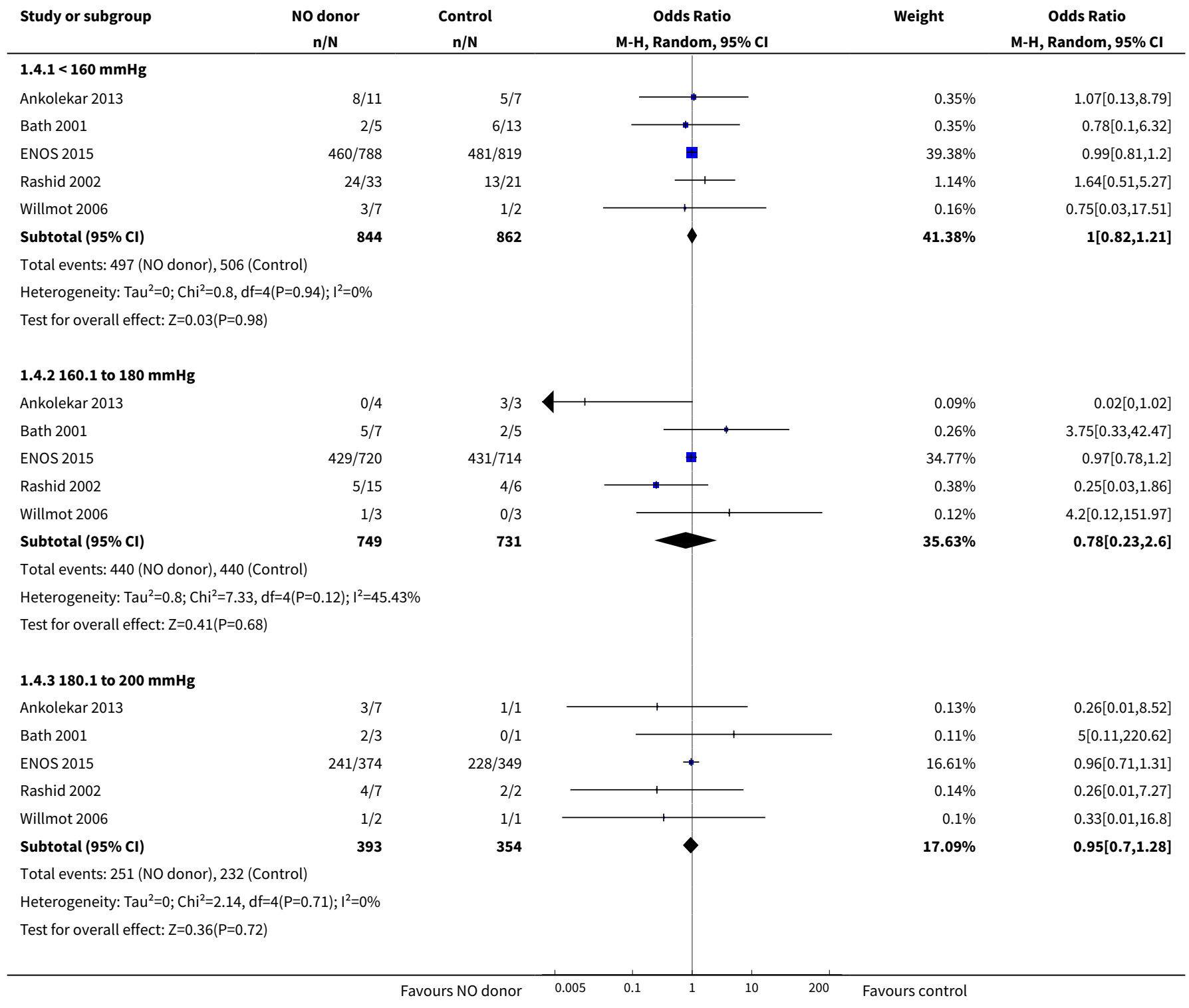




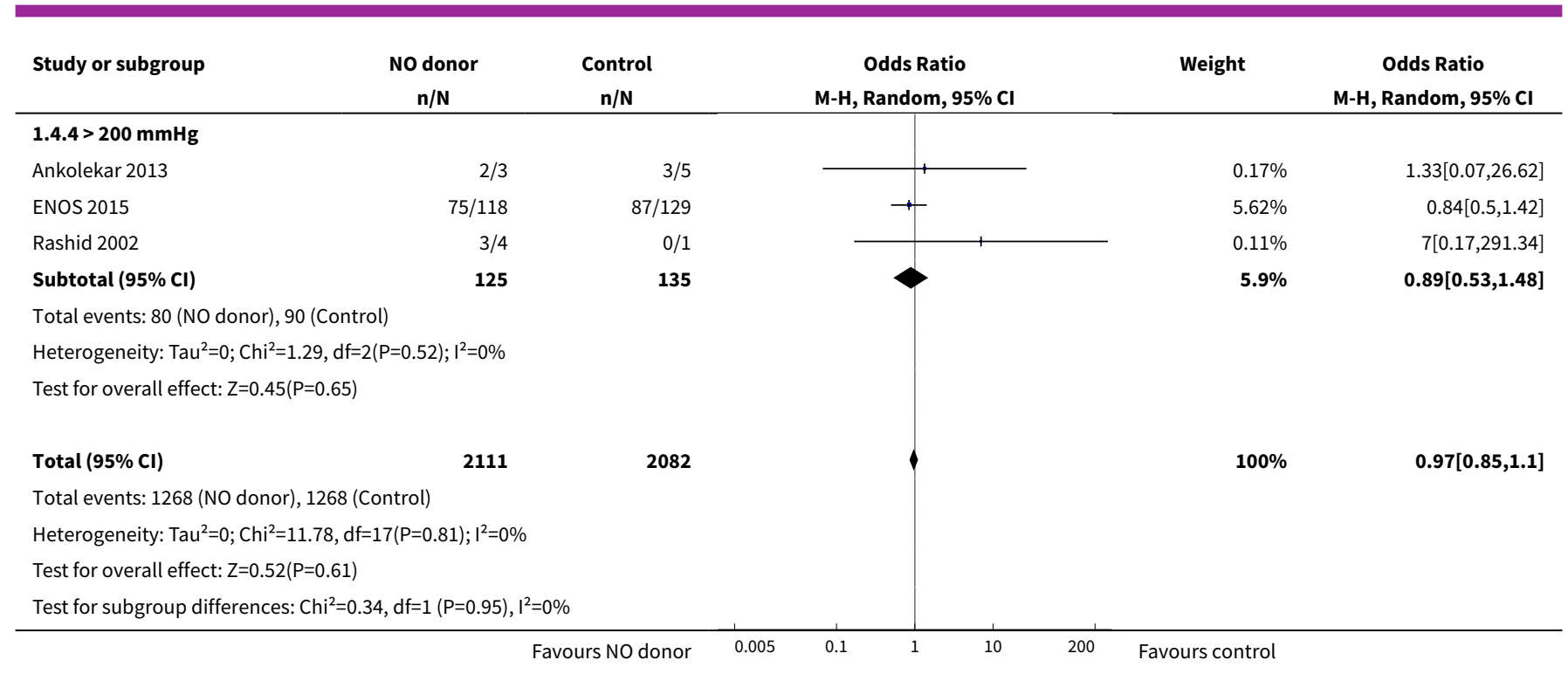

Analysis 1.5. Comparison 1 Glyceryl trinitrate (GTN) compared with no GTN for acute stroke, Outcome 5 Death or dependency (mean mRS), end of trial.

\begin{tabular}{|c|c|c|c|c|c|c|c|}
\hline \multirow[t]{2}{*}{ Study or subgroup } & \multicolumn{2}{|c|}{ NO donor } & \multicolumn{2}{|c|}{ Control } & \multirow{2}{*}{$\begin{array}{l}\text { Mean Difference } \\
\text { Random, } 95 \% \mathrm{Cl}\end{array}$} & \multirow[t]{2}{*}{ Weight } & \multirow{2}{*}{$\begin{array}{l}\text { Mean Difference } \\
\text { Random, } 95 \% \mathrm{Cl}\end{array}$} \\
\hline & $\mathbf{N}$ & $\operatorname{Mean}(\mathrm{SD})$ & $\mathbf{N}$ & Mean(SD) & & & \\
\hline \multicolumn{8}{|l|}{ 1.5.1 Overall } \\
\hline Ankolekar 2013 & 25 & $3(1.9)$ & 16 & $4.3(1.8)$ & ⺊ & $10.92 \%$ & $-1.29[-2.44,-0.14]$ \\
\hline Bath 2001 & 16 & $3.5(1.8)$ & 19 & $2.5(1.7)$ & & $10.85 \%$ & $0.97[-0.19,2.13]$ \\
\hline ENOS 2015 & 2000 & $3.1(1.7)$ & 2011 & $3.1(1.8)$ & H & $44.23 \%$ & $-0.03[-0.14,0.08]$ \\
\hline Rashid 2002 & 60 & $2.8(1.6)$ & 30 & $2.9(1.9)$ & & $18.52 \%$ & $-0.16[-0.94,0.62]$ \\
\hline Subtotal $\star \star \star$ & 2113 & & 2082 & & & $100 \%$ & $-0.08[-0.52,0.36]$ \\
\hline \multicolumn{8}{|c|}{ Heterogeneity: $\mathrm{Tau}^{2}=0.11 ; \mathrm{Chi}^{2}=7.56, \mathrm{df}=4(\mathrm{P}=0.11) ; \mathrm{I}^{2}=47.08 \%$} \\
\hline \multicolumn{8}{|c|}{ Test for overall effect: $Z=0.35(P=0.72)$} \\
\hline 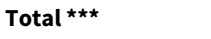 & 2113 & & 2082 & & & $100 \%$ & $-0.08[-0.52,0.36]$ \\
\hline \multicolumn{8}{|c|}{ Heterogeneity: $\mathrm{Tau}^{2}=0.11 ; \mathrm{Chi}^{2}=7.56, \mathrm{df}=4(\mathrm{P}=0.11) ; \mathrm{I}^{2}=47.08 \%$} \\
\hline
\end{tabular}

\section{Analysis 1.6. Comparison 1 Glyceryl trinitrate (GTN) compared with no GTN for acute stroke, Outcome 6 Death or dependency (mean mRS), end of trial, by stroke type.}

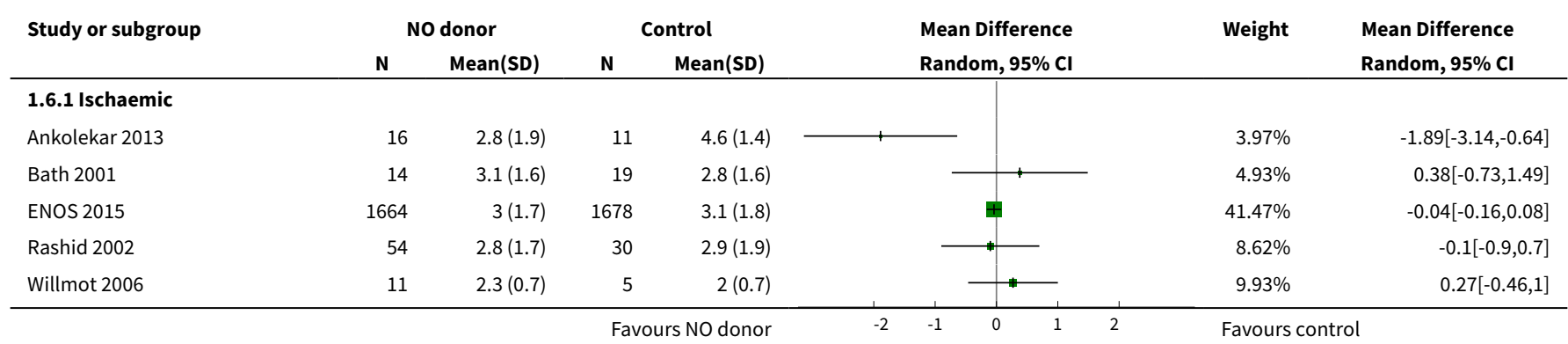




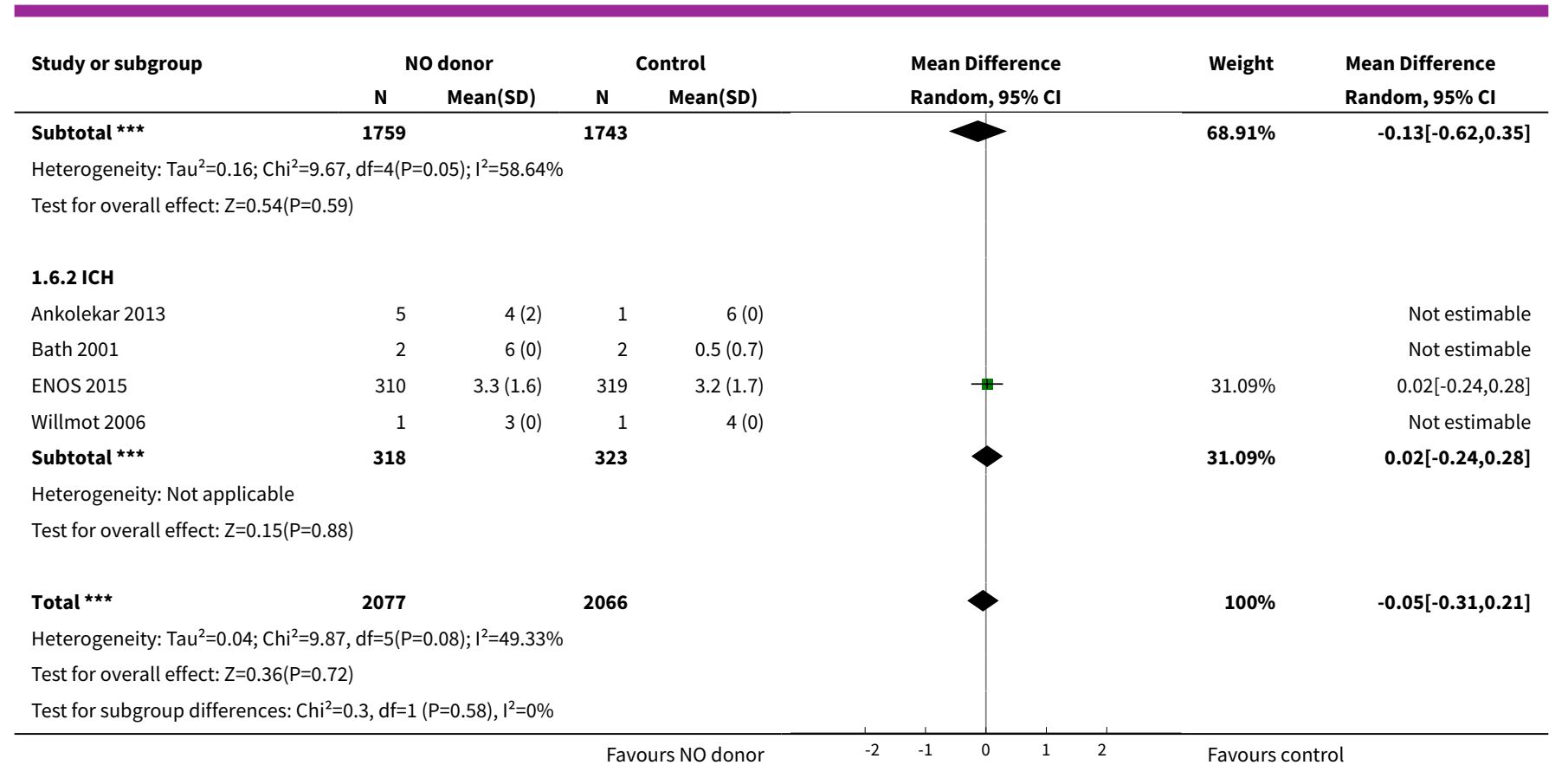

Analysis 1.7. Comparison 1 Glyceryl trinitrate (GTN) compared with no GTN for acute stroke, Outcome 7 Death or dependency (mean $\mathrm{mRS}$ ), end of trial, by time to randomisation.

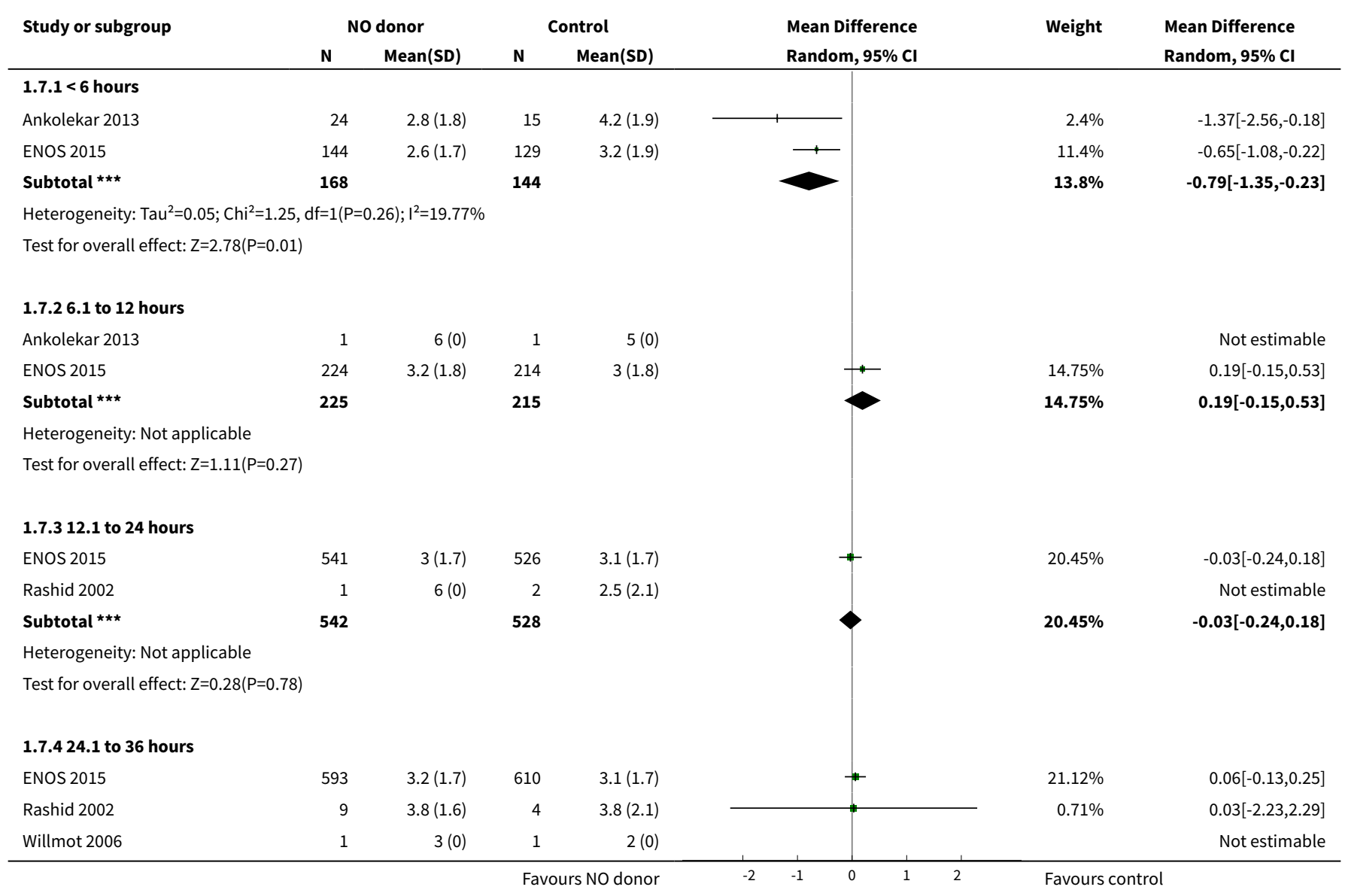




\begin{tabular}{|c|c|c|c|c|c|c|c|}
\hline \multirow[t]{2}{*}{ Study or subgroup } & \multicolumn{2}{|c|}{ NO donor } & \multicolumn{2}{|c|}{ Control } & \multirow{2}{*}{$\begin{array}{l}\text { Mean Difference } \\
\text { Random, } 95 \% \mathrm{Cl}\end{array}$} & \multirow[t]{2}{*}{ Weight } & \multirow{2}{*}{$\begin{array}{l}\text { Mean Difference } \\
\text { Random, 95\% Cl }\end{array}$} \\
\hline & $\mathbf{N}$ & Mean(SD) & $\mathbf{N}$ & Mean(SD) & & & \\
\hline 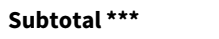 & 603 & & 615 & & & $21.82 \%$ & $0.06[-0.13,0.25]$ \\
\hline \multicolumn{8}{|c|}{ Heterogeneity: $\operatorname{Tau}^{2}=0 ; \mathrm{Chi}^{2}=0, \mathrm{df}=1(\mathrm{P}=0.98) ; \mathrm{I}^{2}=0 \%$} \\
\hline \multicolumn{8}{|c|}{ Test for overall effect: $Z=0.61(P=0.54)$} \\
\hline \multicolumn{8}{|l|}{ 1.7.5 $>36$ hours } \\
\hline Bath 2001 & 16 & $3.5(1.8)$ & 19 & $2.5(1.7)$ & & $2.51 \%$ & $0.97[-0.19,2.13]$ \\
\hline ENOS 2015 & 498 & $3.1(1.6)$ & 532 & $3.1(1.8)$ & & $20.42 \%$ & $-0.07[-0.28,0.14]$ \\
\hline Rashid 2002 & 50 & $2.5(1.5)$ & 24 & $2.8(1.9)$ & & $4.27 \%$ & $-0.31[-1.17,0.55]$ \\
\hline Willmot 2006 & 11 & $2.3(0.7)$ & 4 & $2.5(1.3)$ & & $1.97 \%$ & $-0.23[-1.55,1.09]$ \\
\hline Subtotal ${ }^{\star \star \star}$ & 575 & & 579 & & & $29.18 \%$ & $-0.04[-0.35,0.28]$ \\
\hline \multicolumn{8}{|c|}{ Heterogeneity: $\mathrm{Tau}^{2}=0.02 ; \mathrm{Chi}^{2}=3.44, \mathrm{df}=3(\mathrm{P}=0.33) ; \mathrm{I}^{2}=12.81 \%$} \\
\hline \multicolumn{8}{|c|}{ Test for overall effect: $Z=0.22(P=0.83)$} \\
\hline 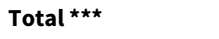 & 2113 & & 2081 & & & $100 \%$ & $-0.08[-0.27,0.11]$ \\
\hline \multicolumn{8}{|c|}{ Heterogeneity: $\mathrm{Tau}^{2}=0.04 ; \mathrm{Chi}^{2}=18.75, \mathrm{df}=9(\mathrm{P}=0.03) ; \mathrm{I}^{2}=52.01 \%$} \\
\hline \multicolumn{8}{|c|}{ Test for overall effect: $Z=0.81(P=0.42)$} \\
\hline \multicolumn{8}{|c|}{ Test for subgroup differences: $\mathrm{Chi}^{2}=9.43, \mathrm{df}=1(\mathrm{P}=0.05), \mathrm{I}^{2}=57.6 \%$} \\
\hline
\end{tabular}

\section{Analysis 1.8. Comparison 1 Glyceryl trinitrate (GTN) compared with no GTN for acute stroke, Outcome 8 Death or dependency (mean mRS), end of trial, by baseline SBP.}

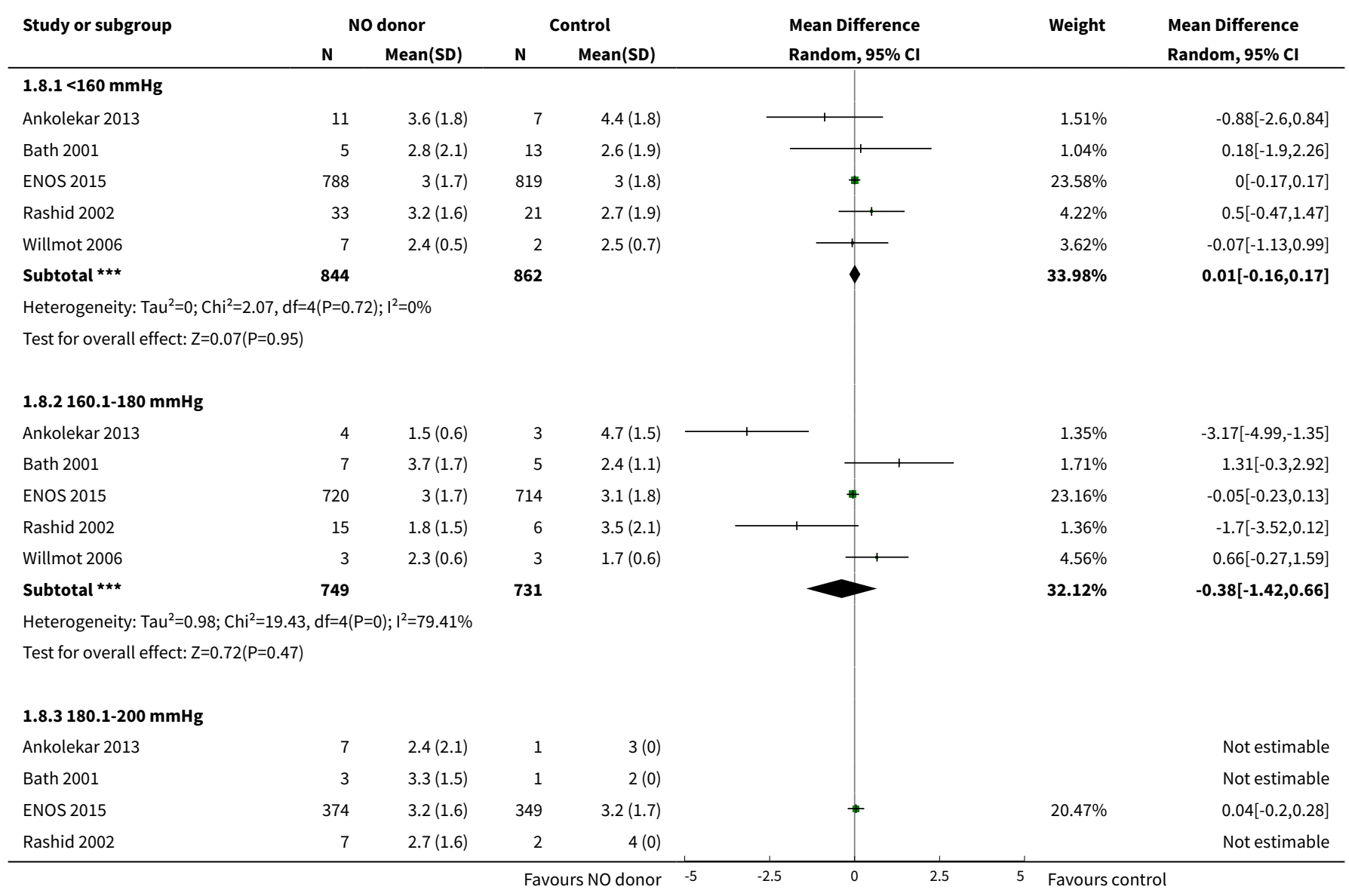




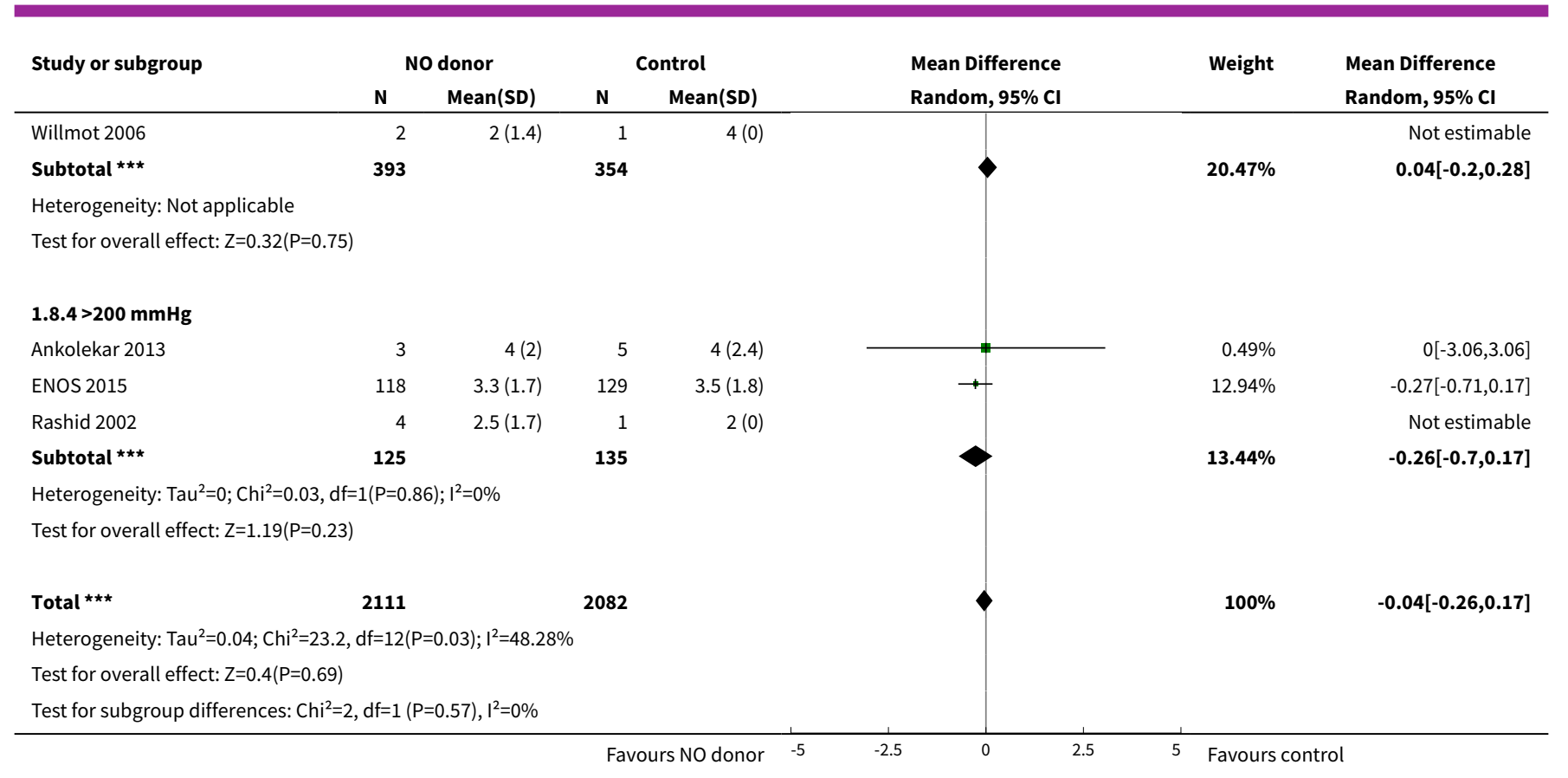

Analysis 1.9. Comparison 1 Glyceryl trinitrate (GTN) compared with no GTN for acute stroke, Outcome 9 Death, end of treatment.

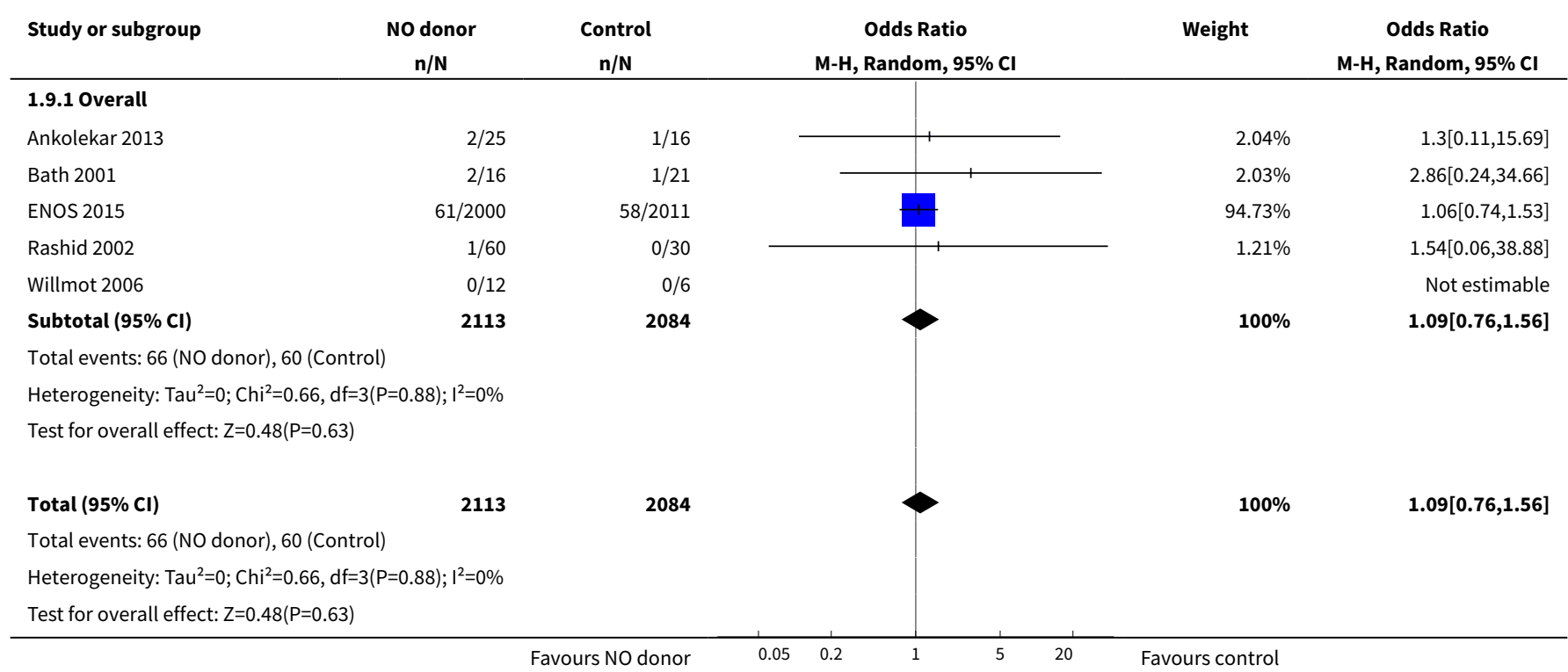

Analysis 1.10. Comparison 1 Glyceryl trinitrate (GTN) compared with no GTN for acute stroke, Outcome 10 Death, end of treatment, by stroke type.

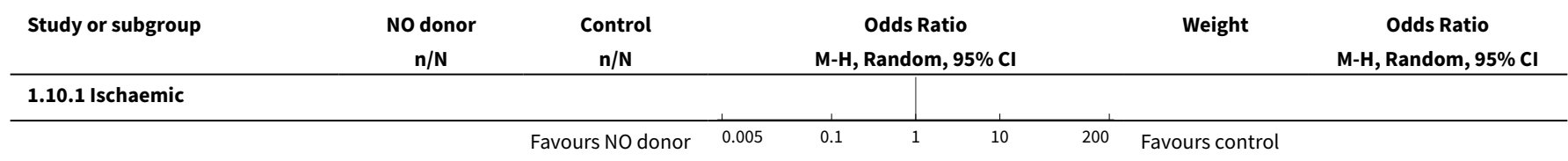




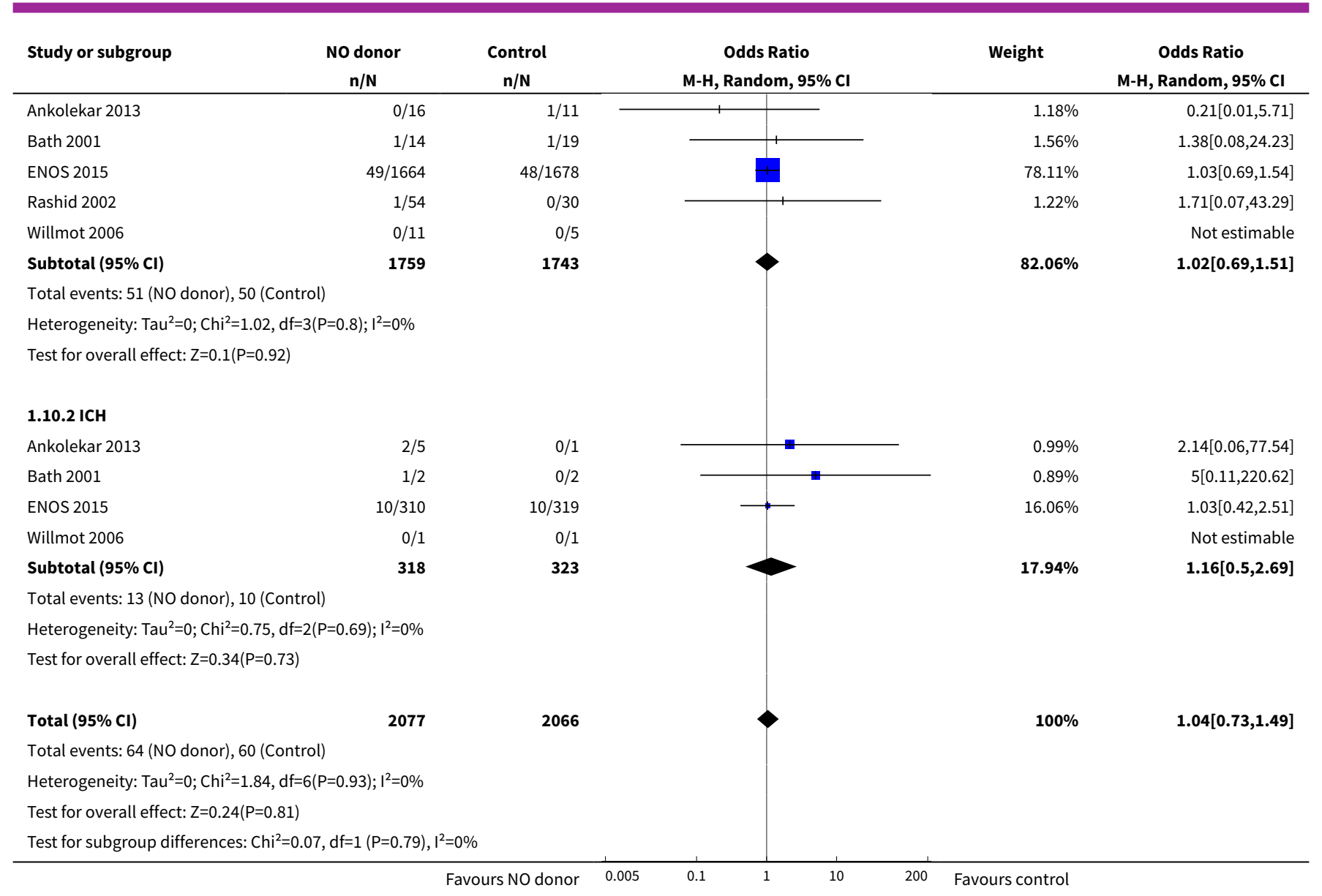

Analysis 1.11. Comparison 1 Glyceryl trinitrate (GTN) compared with no GTN for acute stroke, Outcome 11 Death, end of treatment, by time to randomisation.

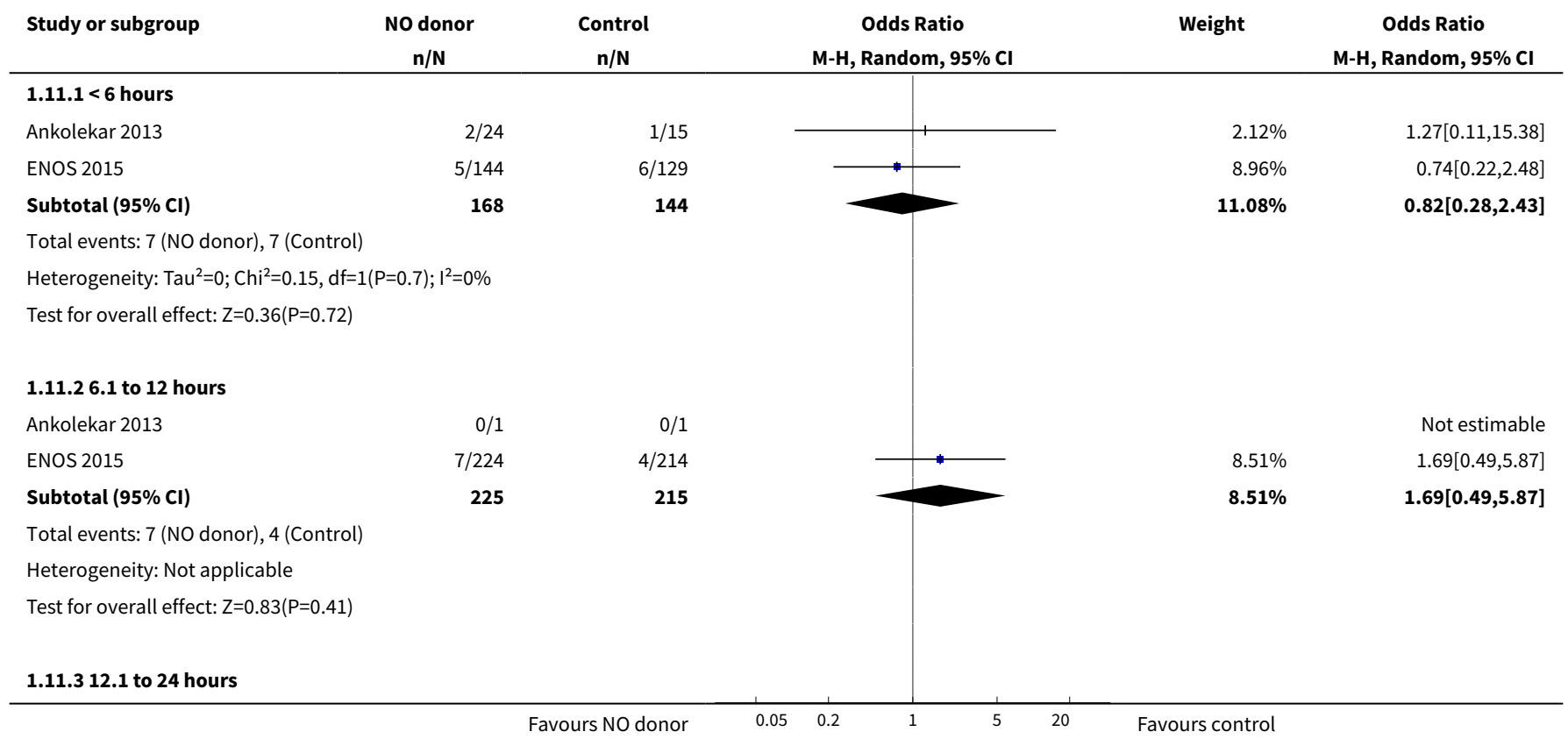




\begin{tabular}{|c|c|c|c|c|c|}
\hline Study or subgroup & $\begin{array}{c}\text { NO donor } \\
n / N\end{array}$ & $\begin{array}{c}\text { Control } \\
\mathrm{n} / \mathrm{N}\end{array}$ & $\begin{array}{c}\text { Odds Ratio } \\
\text { M-H, Random, } 95 \% \mathrm{CI}\end{array}$ & Weight & $\begin{array}{c}\text { Odds Ratio } \\
\text { M-H, Random, } 95 \% \mathrm{Cl}\end{array}$ \\
\hline ENOS 2015 & $21 / 541$ & $24 / 526$ & 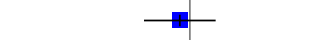 & $36.72 \%$ & $0.84[0.46,1.54]$ \\
\hline Rashid 2002 & $0 / 1$ & $0 / 2$ & & & Not estimable \\
\hline Subtotal $(95 \% \mathrm{CI})$ & 542 & 528 & & $36.72 \%$ & $0.84[0.46,1.54]$ \\
\hline \multicolumn{6}{|c|}{ Total events: 21 (NO donor), 24 (Control) } \\
\hline \multicolumn{6}{|c|}{ Heterogeneity: Not applicable } \\
\hline \multicolumn{6}{|c|}{ Test for overall effect: $Z=0.55(P=0.58)$} \\
\hline \multicolumn{6}{|c|}{ 1.11.4 24.1 to 36 hours } \\
\hline ENOS 2015 & $20 / 593$ & $11 / 610$ & $\longrightarrow$ & $23.71 \%$ & $1.9[0.9,4]$ \\
\hline Rashid 2002 & $0 / 9$ & $0 / 4$ & & & Not estimable \\
\hline Willmot 2006 & $0 / 1$ & $0 / 1$ & & & Not estimable \\
\hline Subtotal $(95 \% \mathrm{CI})$ & 603 & 615 & & $23.71 \%$ & $1.9[0.9,4]$ \\
\hline \multicolumn{6}{|c|}{ Total events: 20 (NO donor), 11 (Control) } \\
\hline \multicolumn{6}{|c|}{ Heterogeneity: $\operatorname{Tau}^{2}=0 ; \mathrm{Chi}^{2}=0, \mathrm{df}=0(\mathrm{P}<0.0001) ; \mathrm{I}^{2}=100 \%$} \\
\hline \multicolumn{6}{|c|}{ Test for overall effect: $Z=1.69(P=0.09)$} \\
\hline \multicolumn{6}{|l|}{ 1.11.5 $>36$ hours } \\
\hline Bath 2001 & $2 / 16$ & $1 / 20$ & & $2.11 \%$ & $2.71[0.22,32.99]$ \\
\hline ENOS 2015 & $8 / 498$ & $13 / 532$ & $\longrightarrow$ & $16.62 \%$ & $0.65[0.27,1.59]$ \\
\hline Rashid 2002 & $1 / 50$ & $0 / 24$ & & $1.25 \%$ & $1.48[0.06,37.8]$ \\
\hline Willmot 2006 & $0 / 11$ & $0 / 4$ & & & Not estimable \\
\hline Subtotal $(95 \% \mathrm{CI})$ & 575 & 580 & & $19.98 \%$ & $0.8[0.35,1.8]$ \\
\hline \multicolumn{6}{|c|}{ Total events: 11 (NO donor), 14 (Control) } \\
\hline \multicolumn{6}{|c|}{ Heterogeneity: $\operatorname{Tau}^{2}=0 ; \mathrm{Chi}^{2}=1.26, \mathrm{df}=2(\mathrm{P}=0.53) ; \mathrm{I}^{2}=0 \%$} \\
\hline \multicolumn{6}{|c|}{ Test for overall effect: $Z=0.55(P=0.59)$} \\
\hline Total $(95 \% \mathrm{Cl})$ & 2113 & 2082 & & $100 \%$ & $1.07[0.74,1.54]$ \\
\hline \multicolumn{6}{|c|}{ Total events: 66 (NO donor), 60 (Control) } \\
\hline \multicolumn{6}{|c|}{ Heterogeneity: $\mathrm{Tau}^{2}=0 ; \mathrm{Chi}^{2}=5.56, \mathrm{df}=7(\mathrm{P}=0.59) ; \mathrm{I}^{2}=0 \%$} \\
\hline \multicolumn{6}{|c|}{ Test for overall effect: $Z=0.37(P=0.71)$} \\
\hline Test for subgroup dif & , $d f=1(P=0.39)$, & & & & \\
\hline
\end{tabular}

Analysis 1.12. Comparison 1 Glyceryl trinitrate (GTN) compared with no GTN for acute stroke, Outcome 12 Death, end of treatment, by baseline SBP.

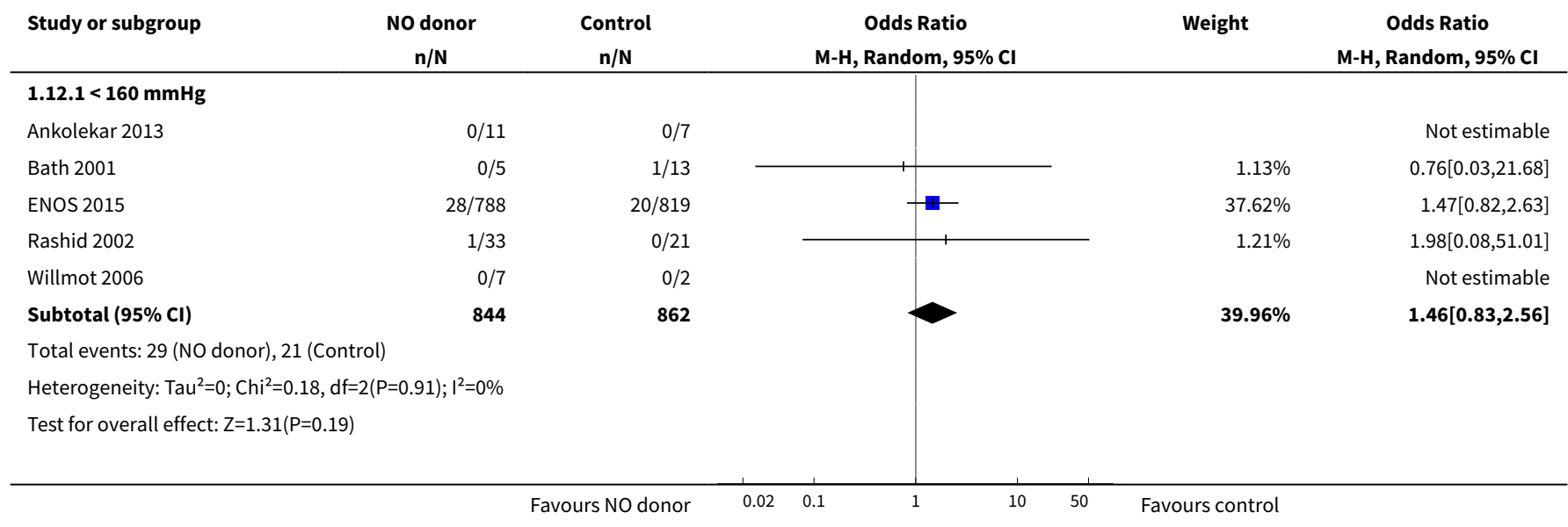




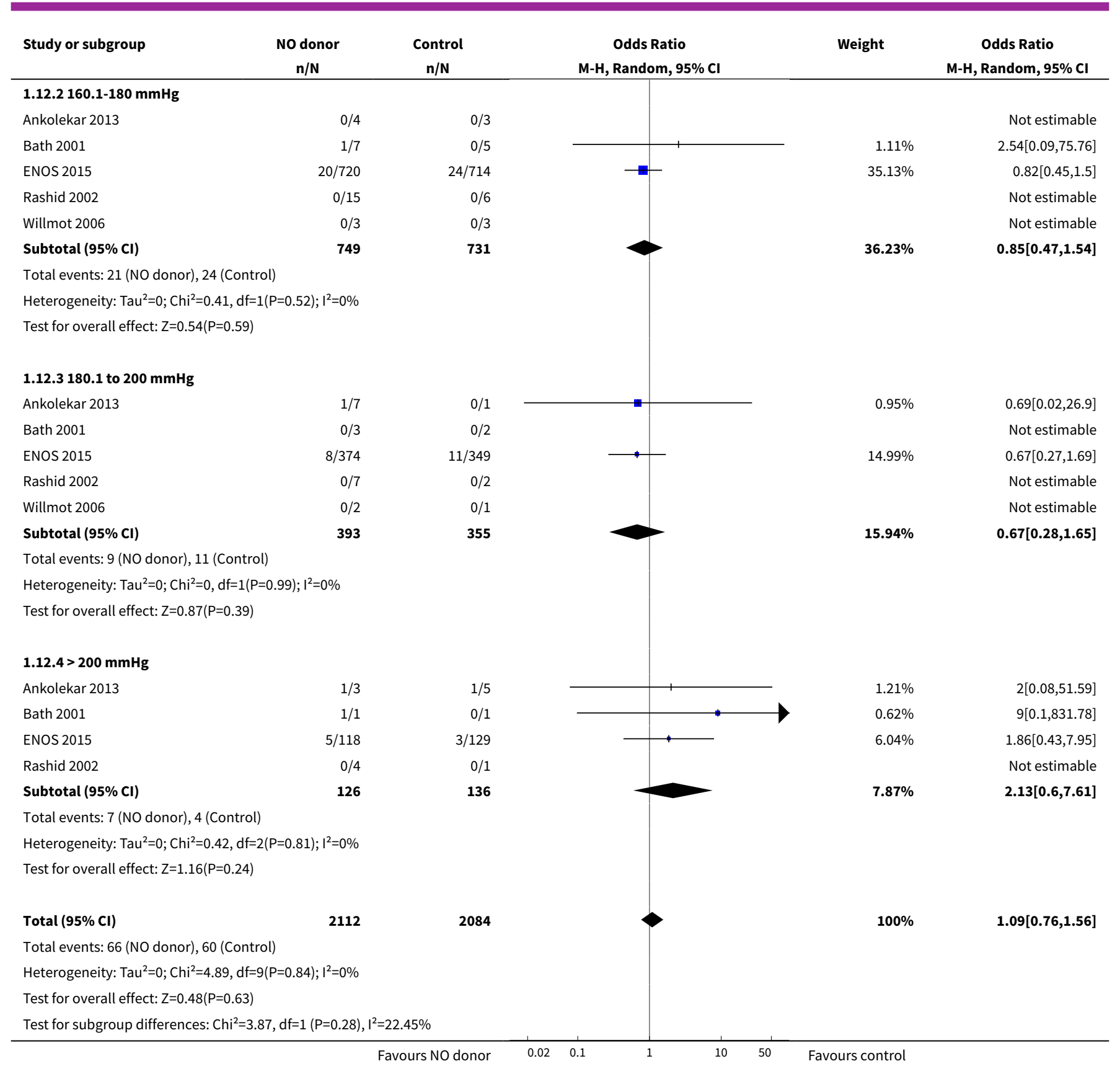

Analysis 1.13. Comparison 1 Glyceryl trinitrate (GTN) compared with no GTN for acute stroke, Outcome 13 Death, end of trial.

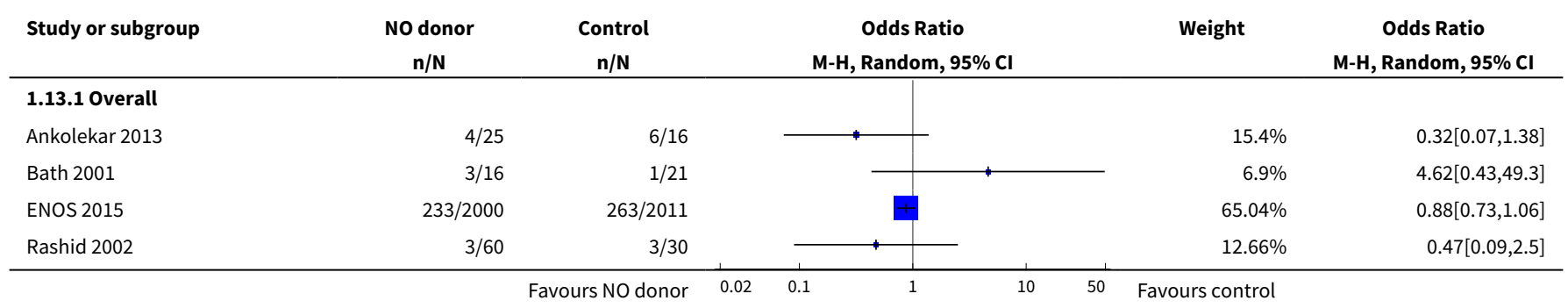




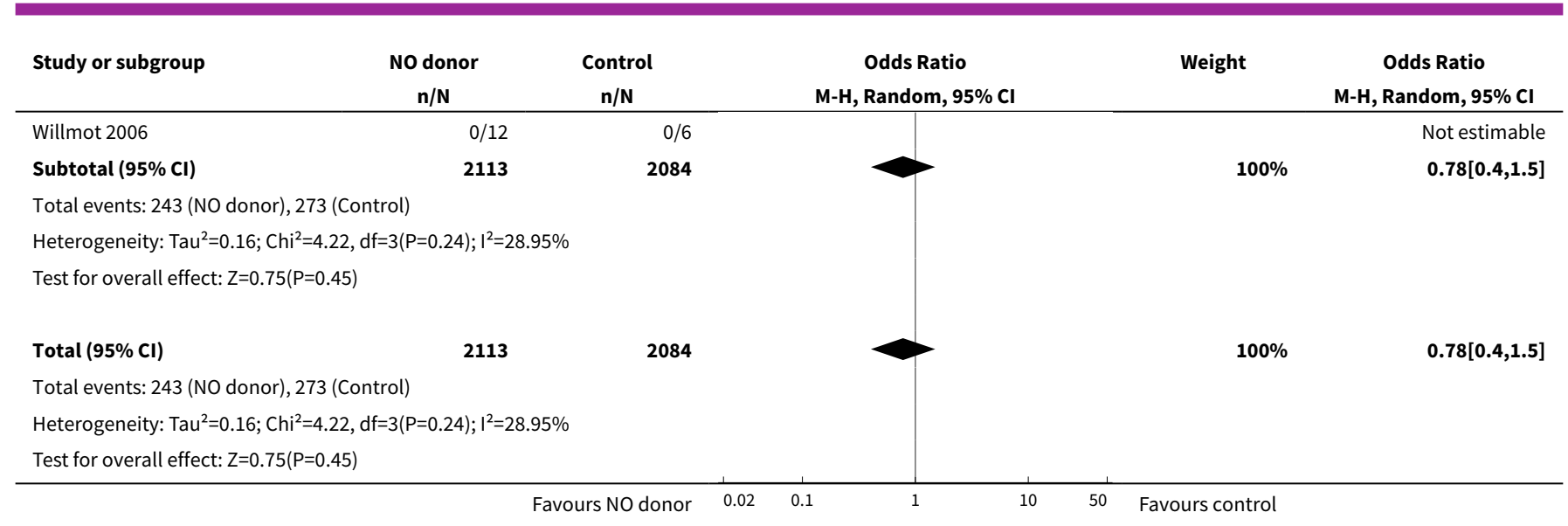

Analysis 1.14. Comparison 1 Glyceryl trinitrate (GTN) compared with no GTN for acute stroke, Outcome 14 Death, end of trial, by stroke type.

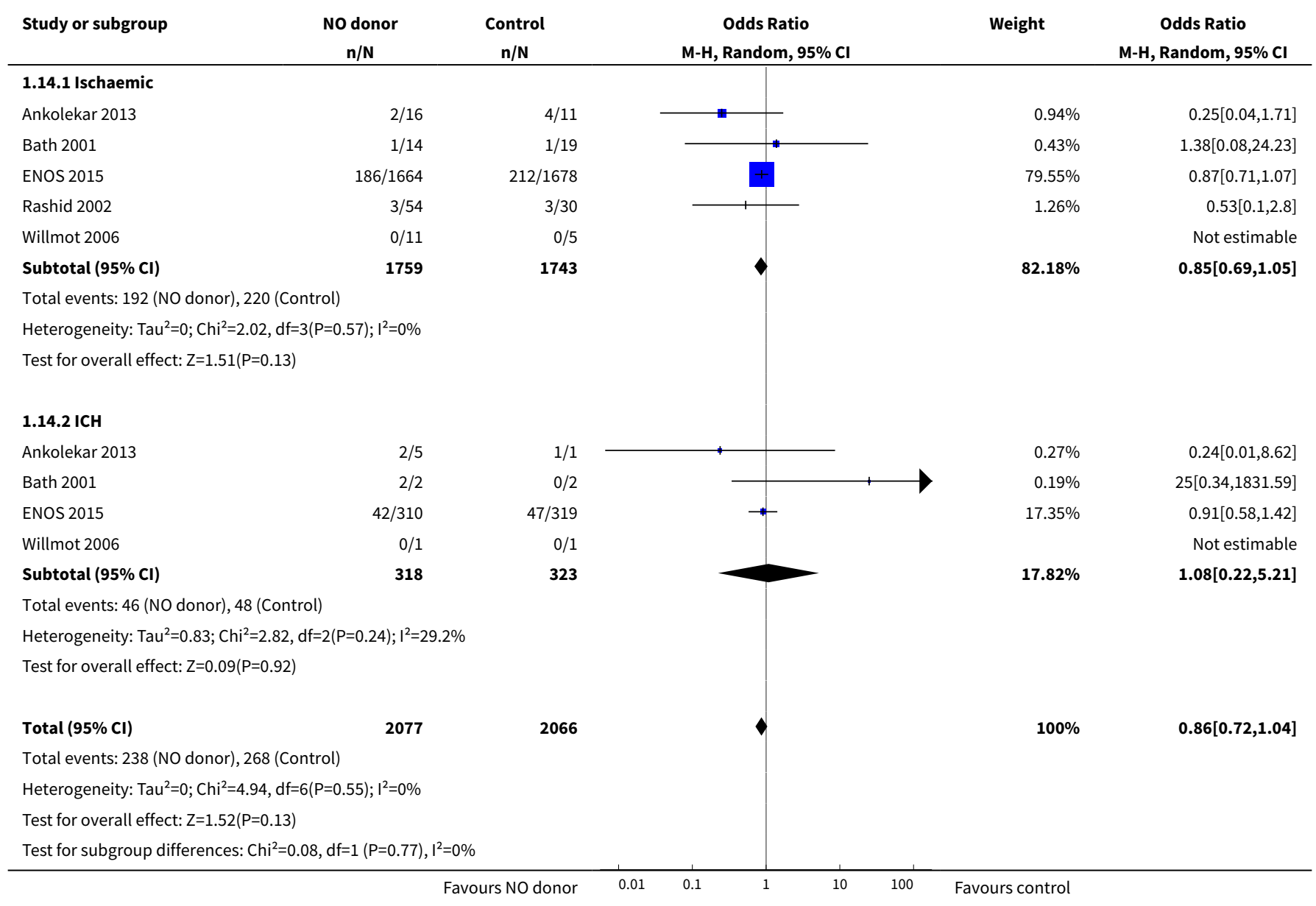


Analysis 1.15. Comparison 1 Glyceryl trinitrate (GTN) compared with no GTN for acute stroke, Outcome 15 Death, end of trial, by time to randomisation.

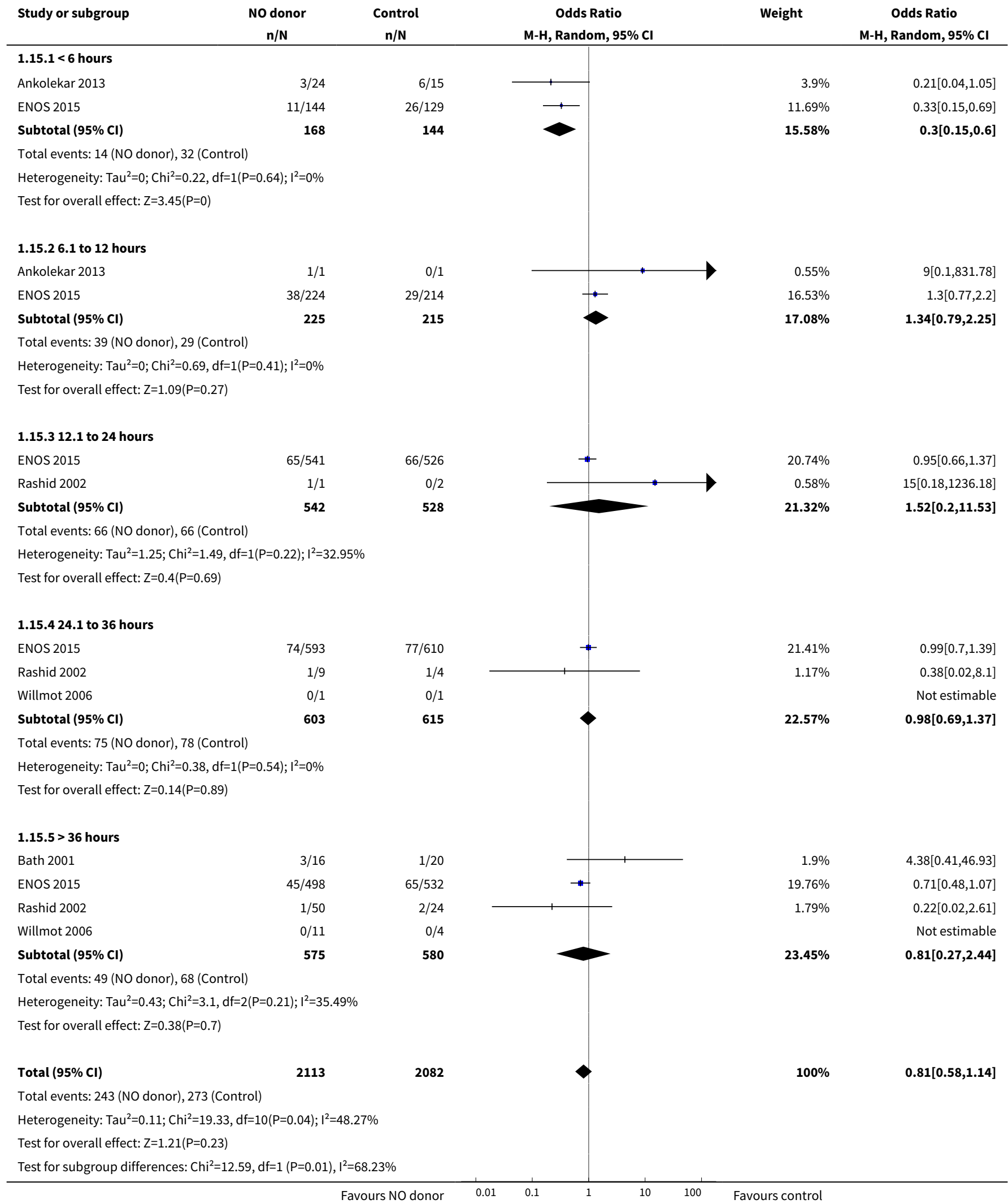




\section{Analysis 1.16. Comparison 1 Glyceryl trinitrate (GTN) compared with no GTN for acute stroke, Outcome 16 Death, end of trial, by baseline SBP.}

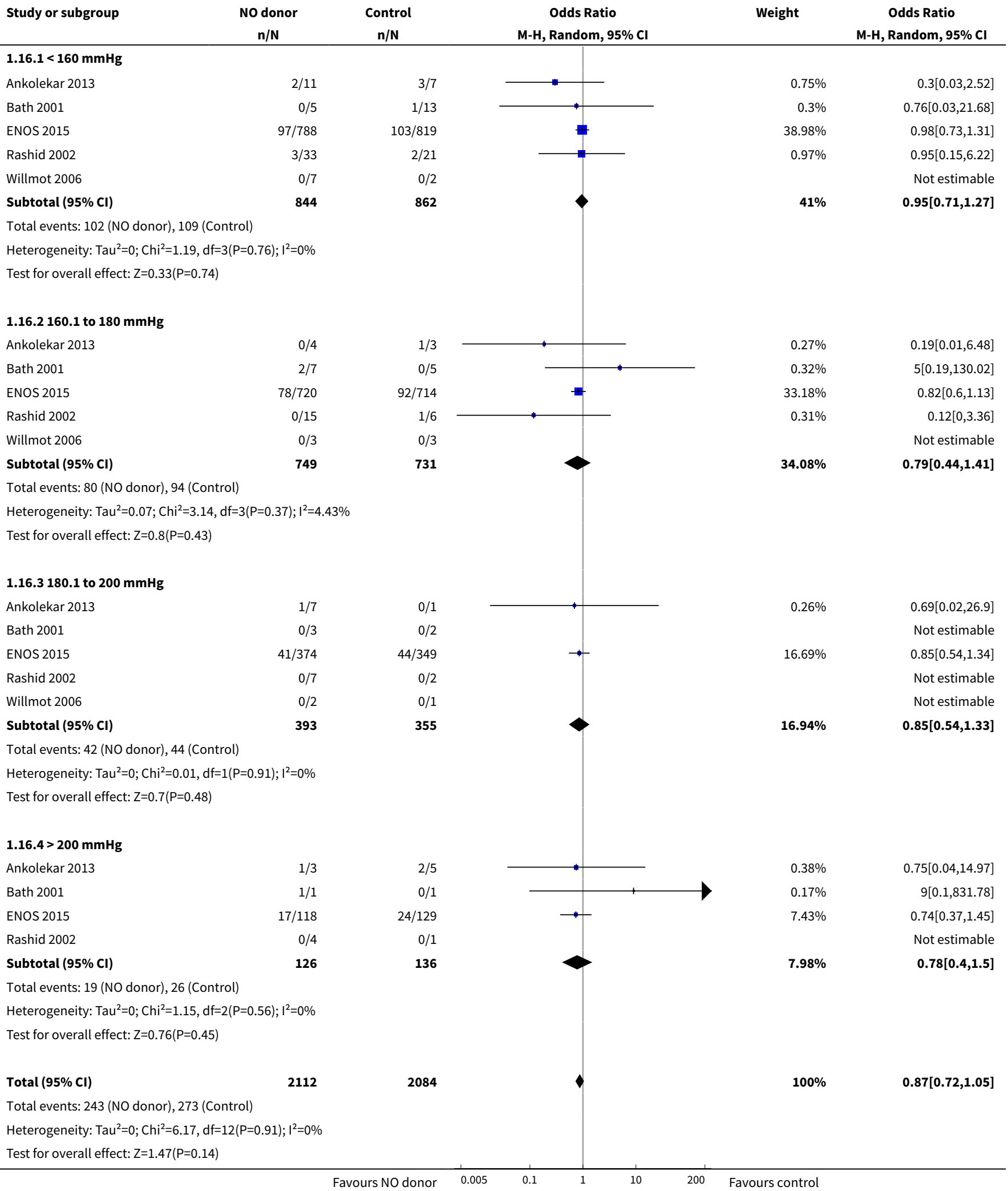




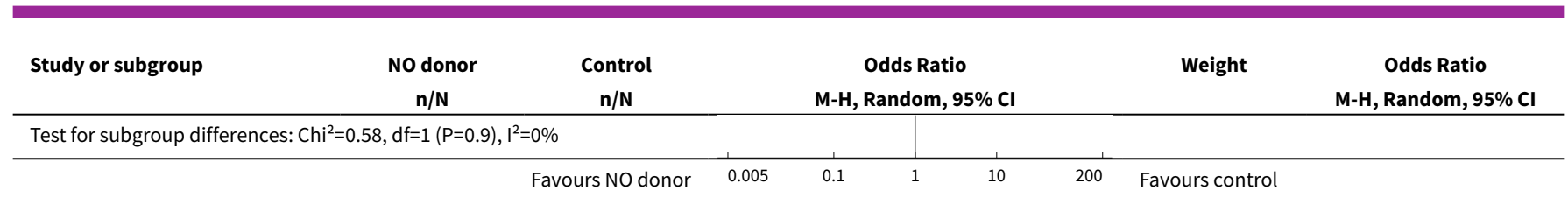

Analysis 1.17. Comparison 1 Glyceryl trinitrate (GTN) compared with no GTN for acute stroke, Outcome 17 Neurological deterioration, end of treatment.

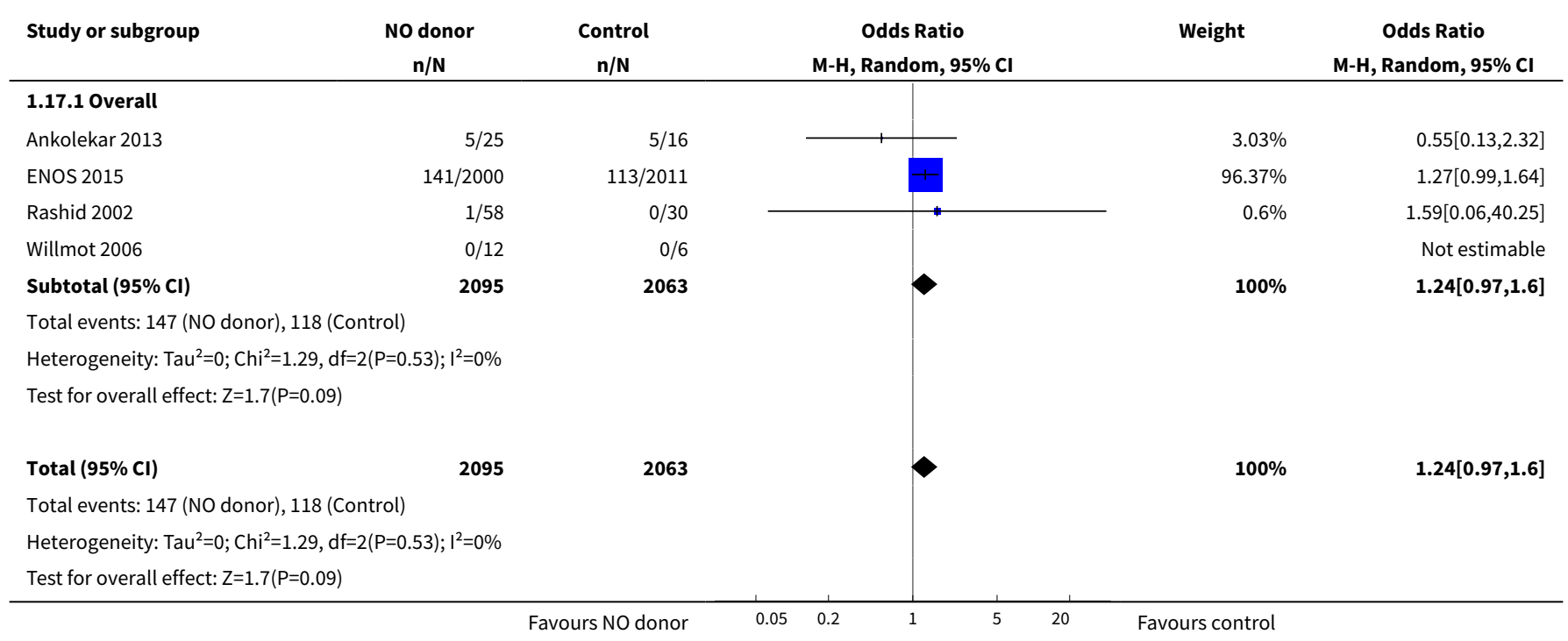

Analysis 1.18. Comparison 1 Glyceryl trinitrate (GTN) compared with no GTN for acute stroke, Outcome 18 Neurological deterioration, end of treatment, by stroke type.

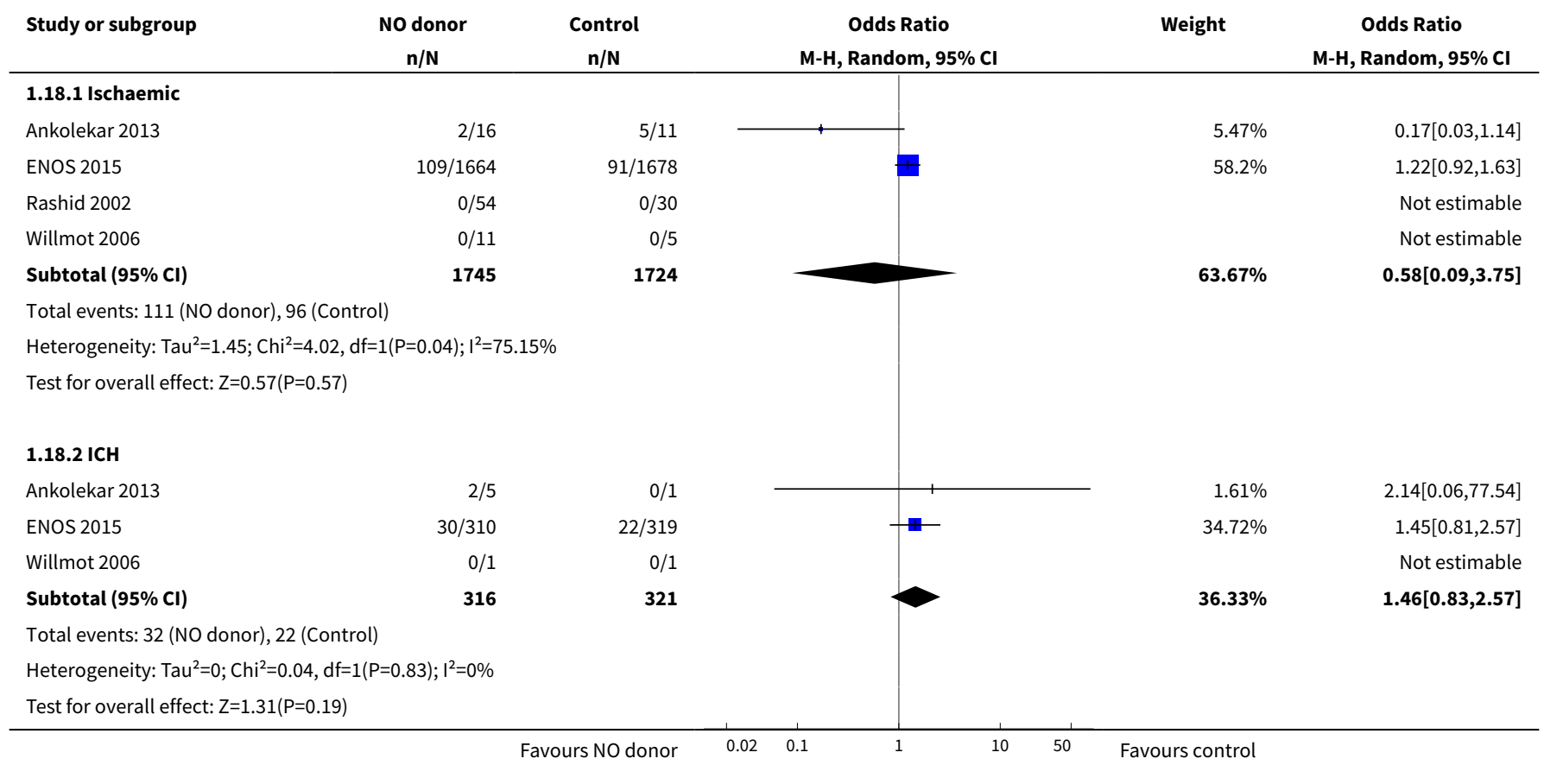




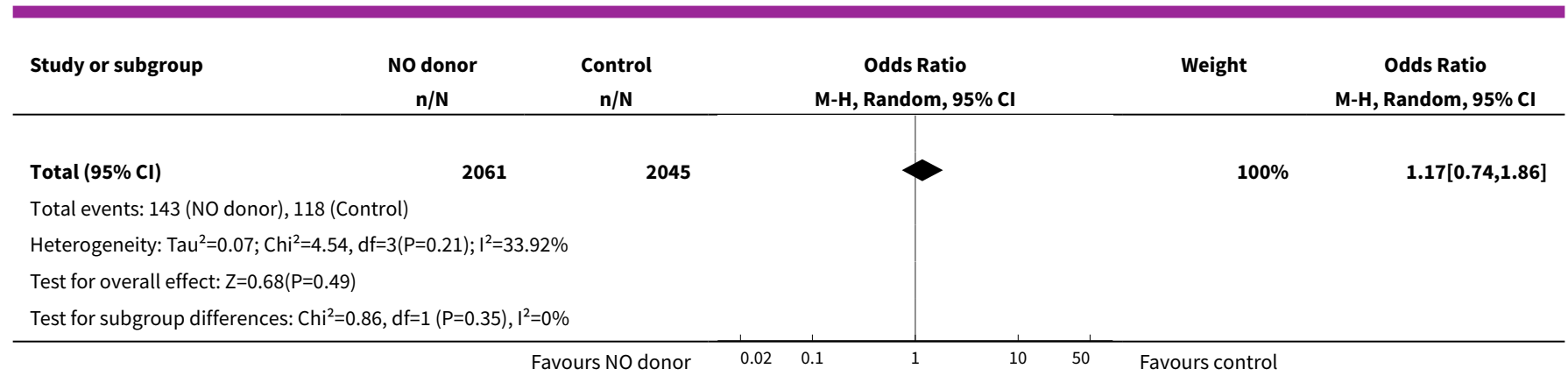

\section{Analysis 1.19. Comparison 1 Glyceryl trinitrate (GTN) compared with no GTN for acute stroke, Outcome 19 Neurological deterioration, end of treatment, by time to randomisation.}

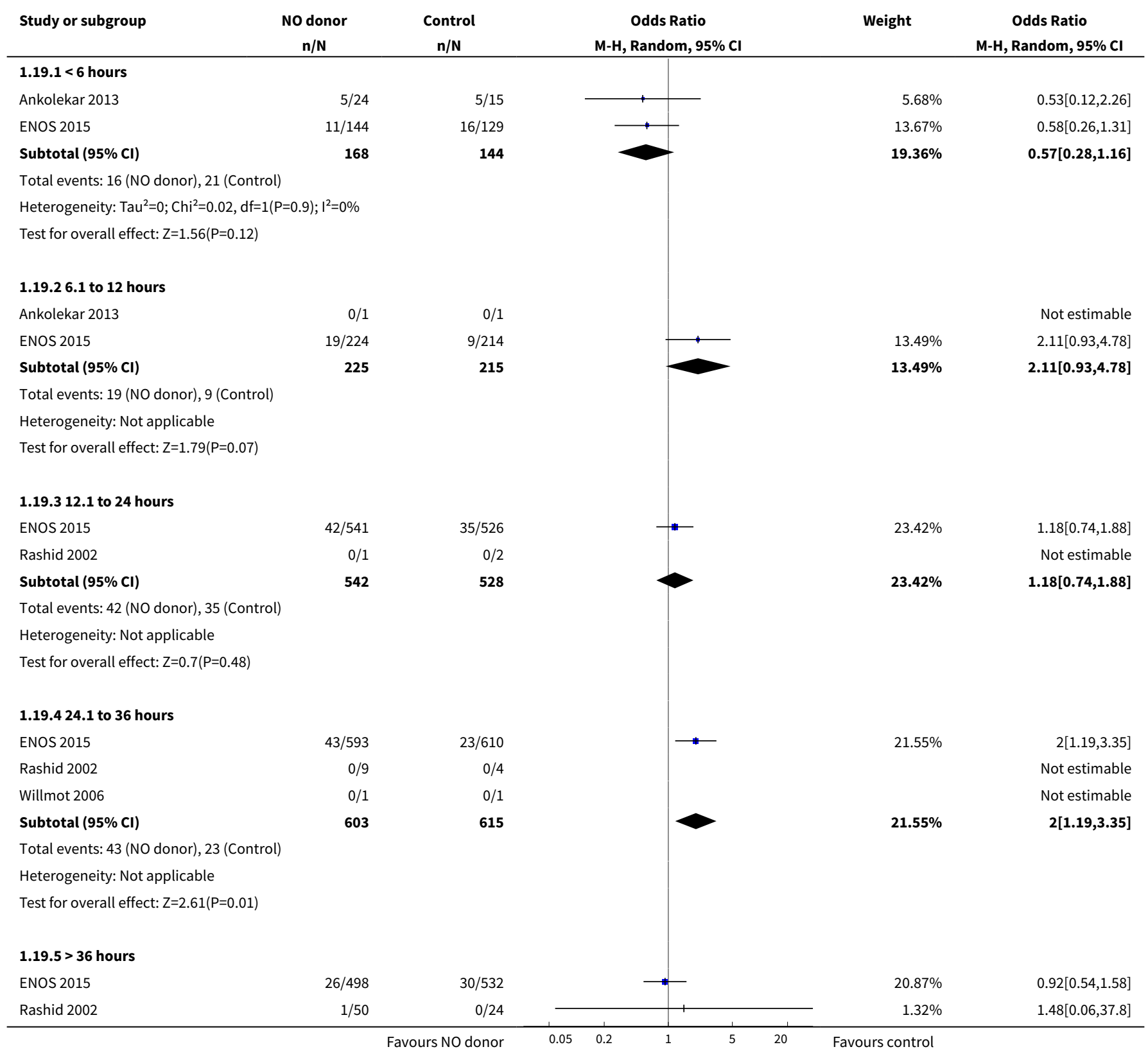




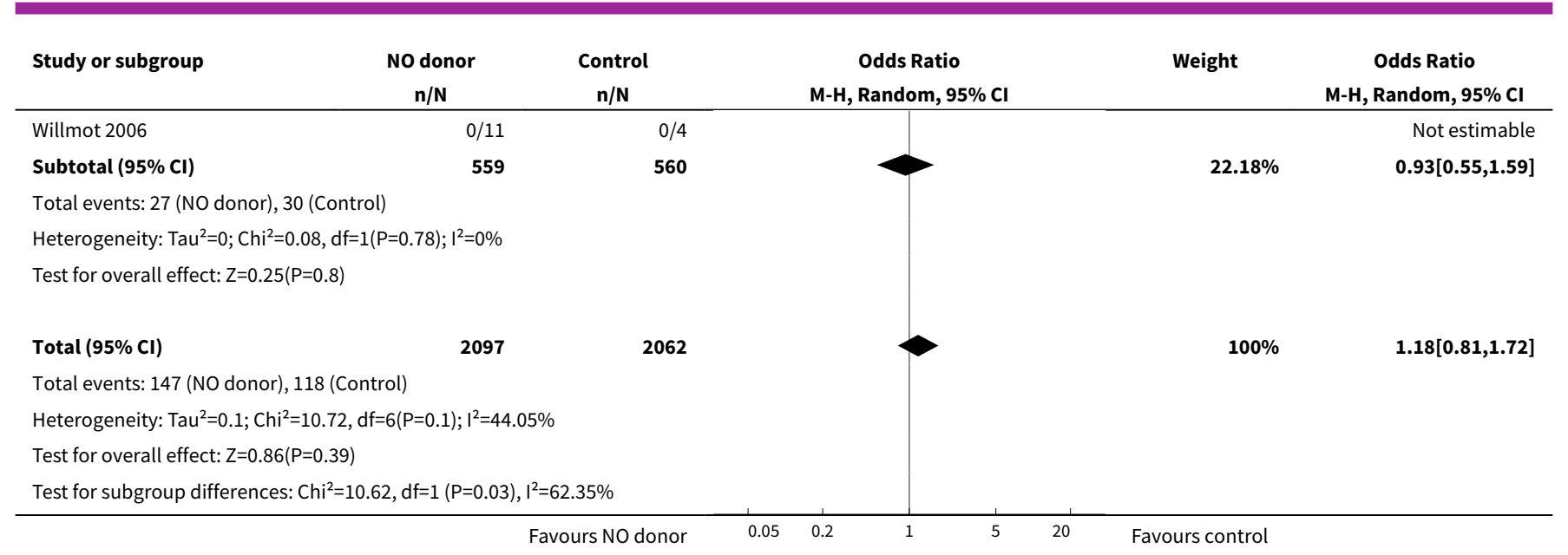

\section{Analysis 1.20. Comparison 1 Glyceryl trinitrate (GTN) compared with no GTN for acute stroke, Outcome 20 Neurological deterioration, end of treatment, by baseline SBP.}

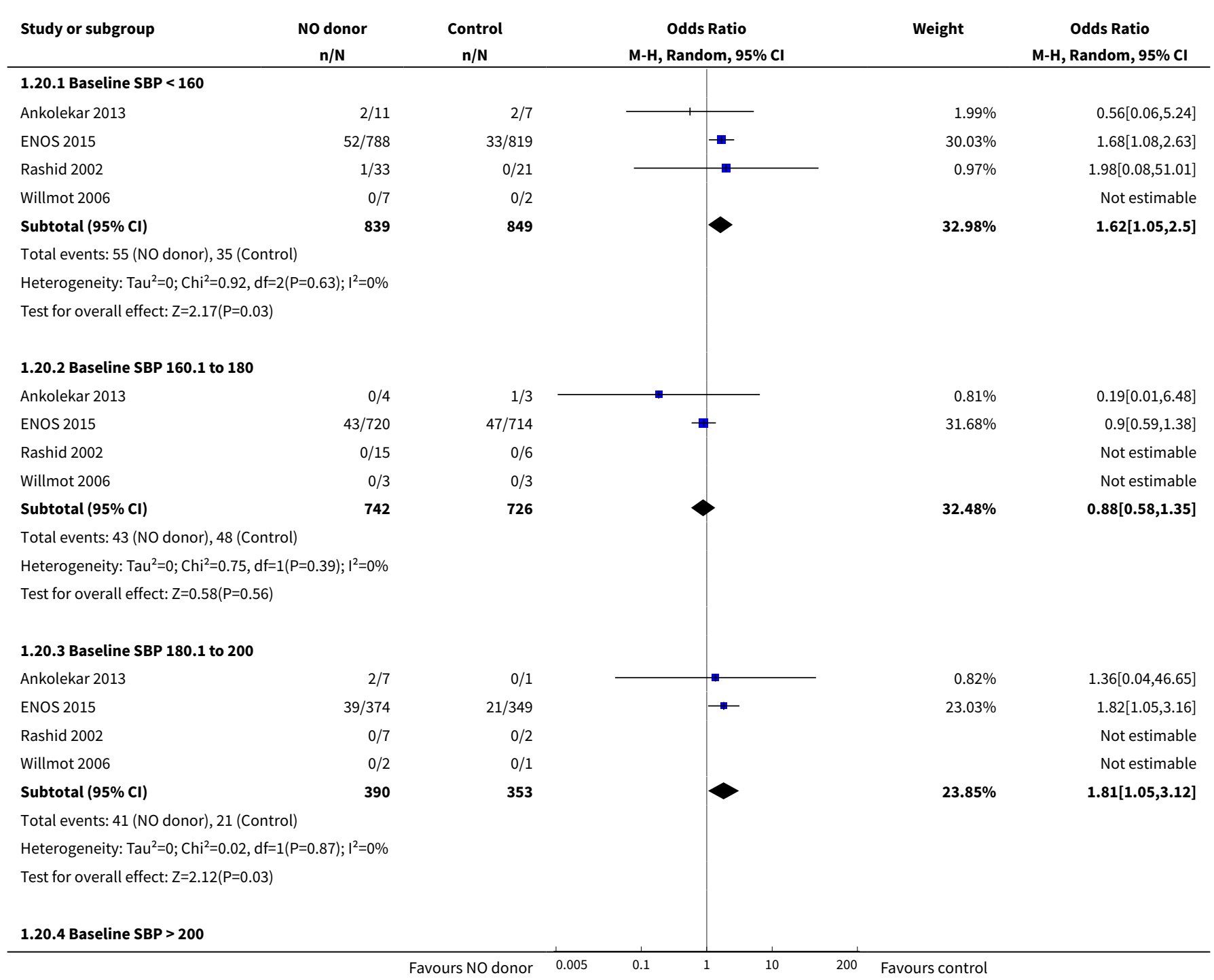




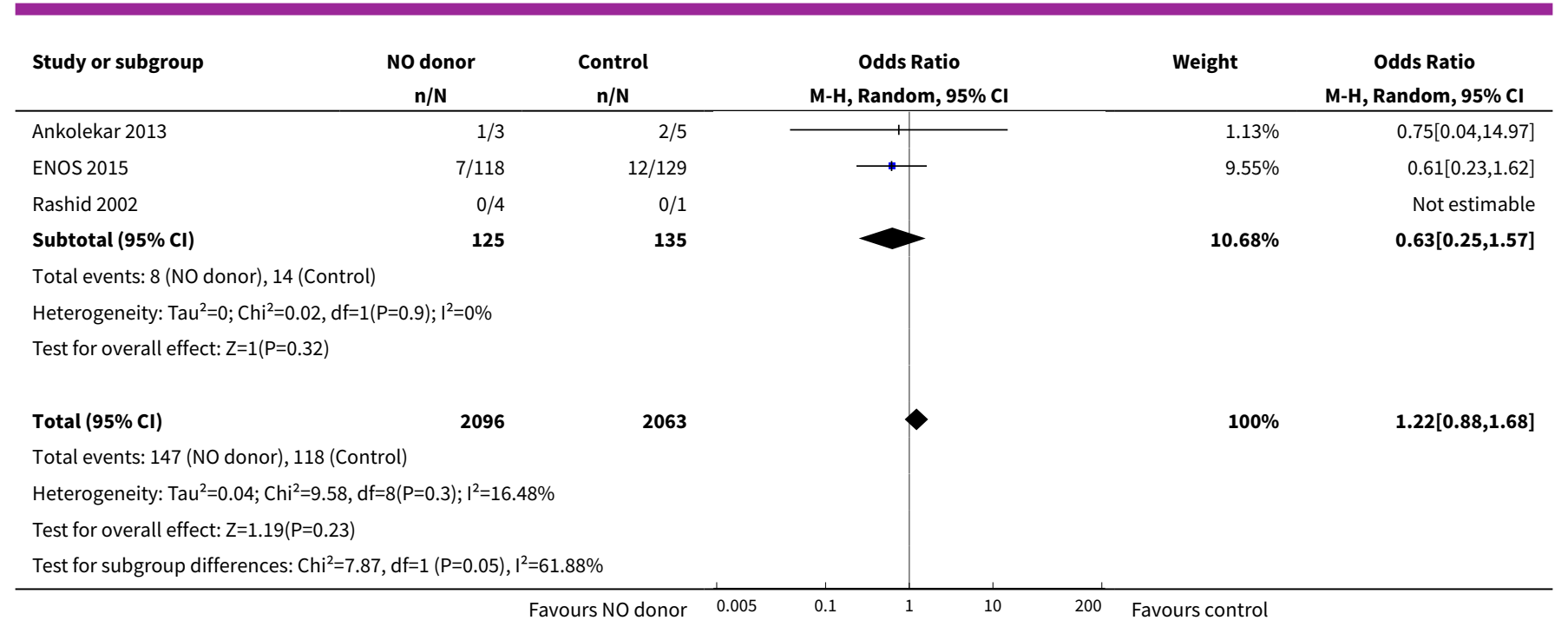

\section{Analysis 1.21. Comparison 1 Glyceryl trinitrate (GTN) compared with no GTN for acute stroke, Outcome 21 NIH Stroke Scale, end of treatment.}

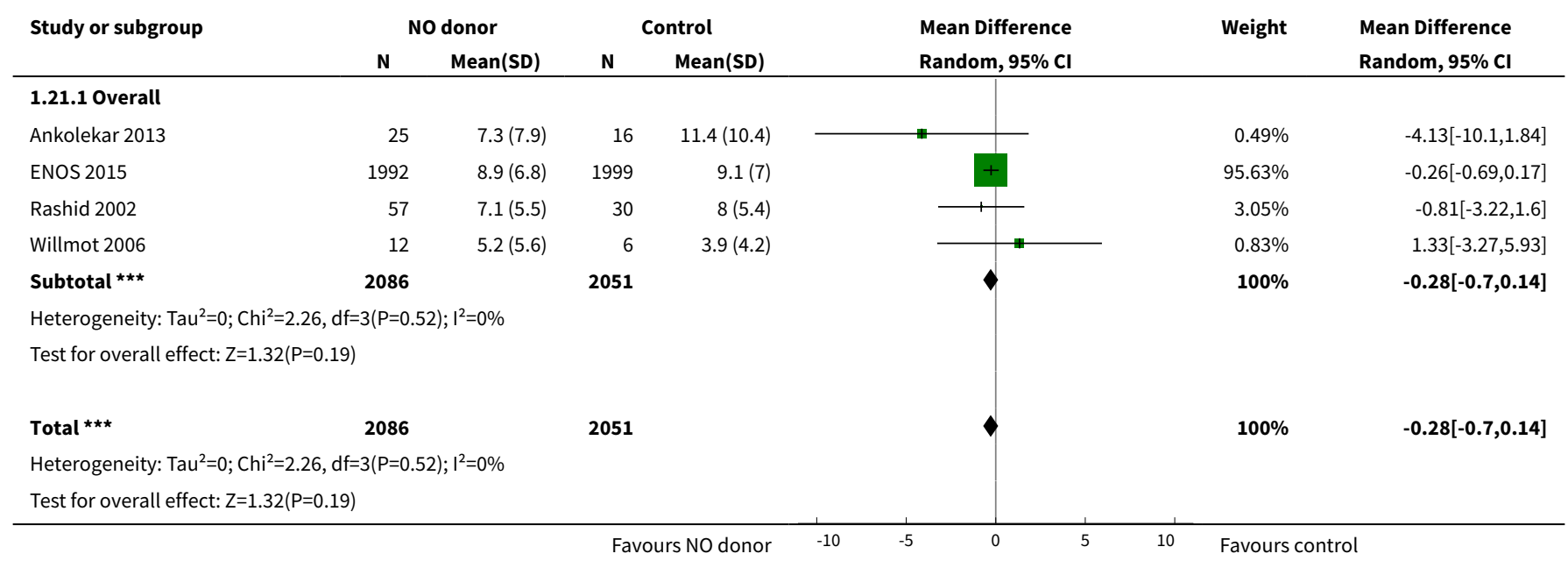

\section{Analysis 1.22. Comparison 1 Glyceryl trinitrate (GTN) compared with no GTN for acute stroke, Outcome 22 NIH Stroke Scale, end of treatment, by stroke type.}

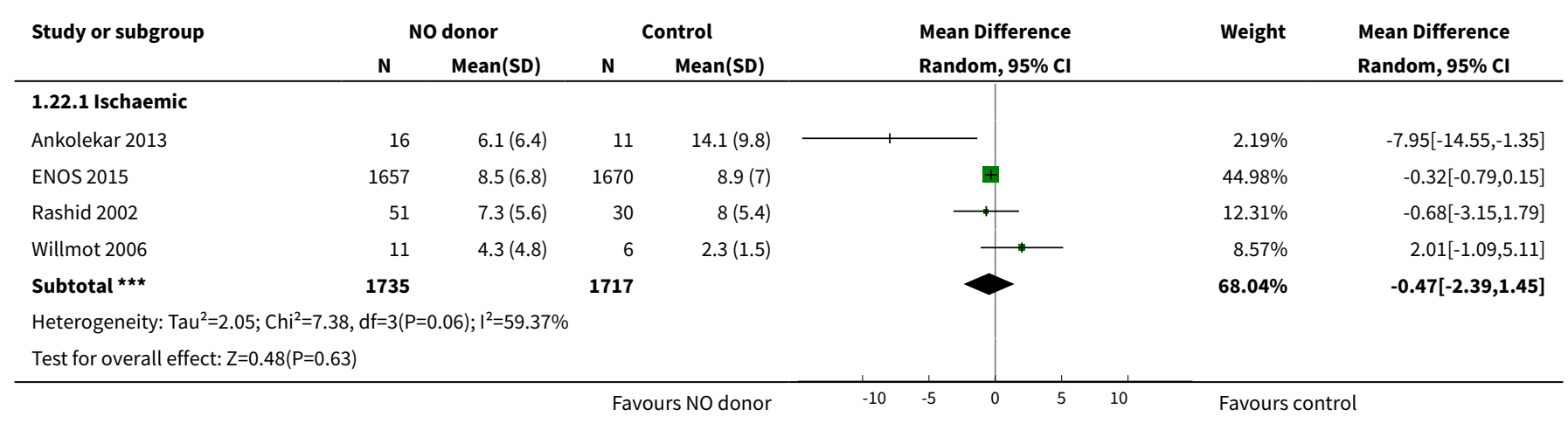




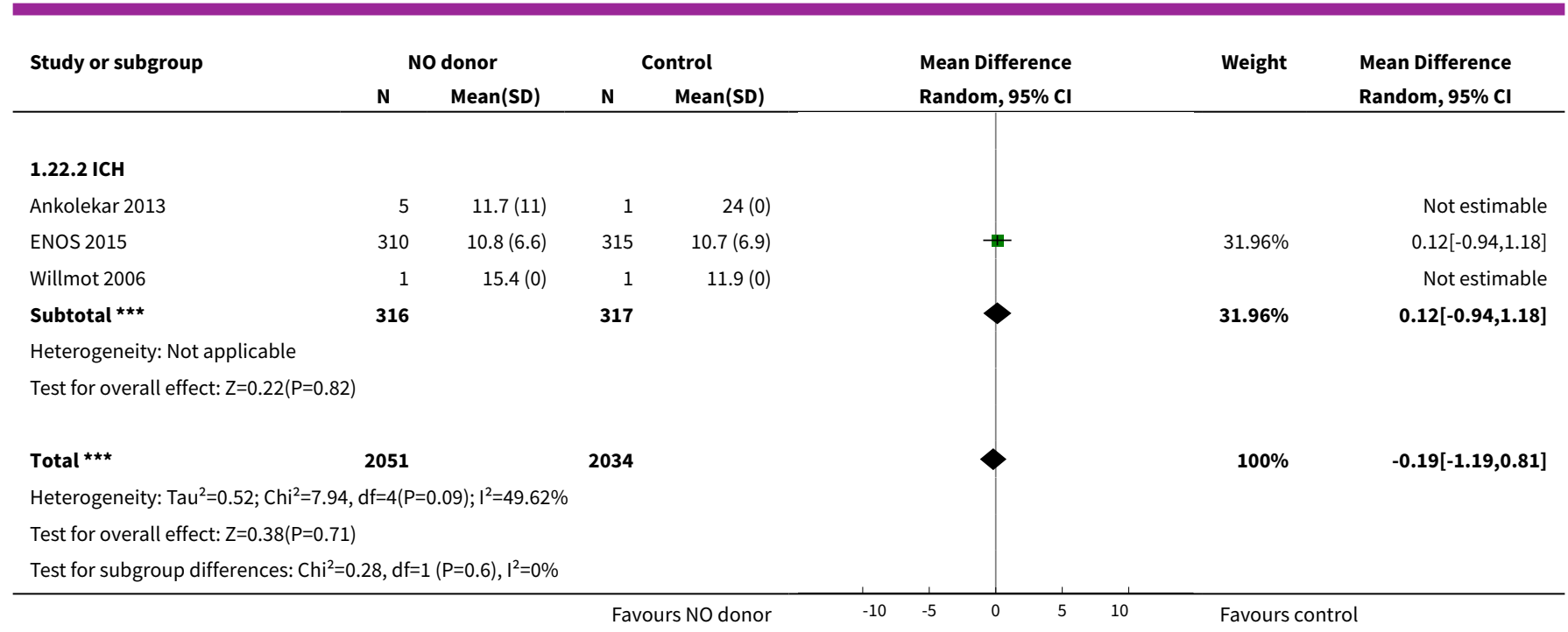

\section{Analysis 1.23. Comparison 1 Glyceryl trinitrate (GTN) compared with no GTN for acute stroke, Outcome 23 NIH Stroke Scale, end of treatment, by time to randomisation.}

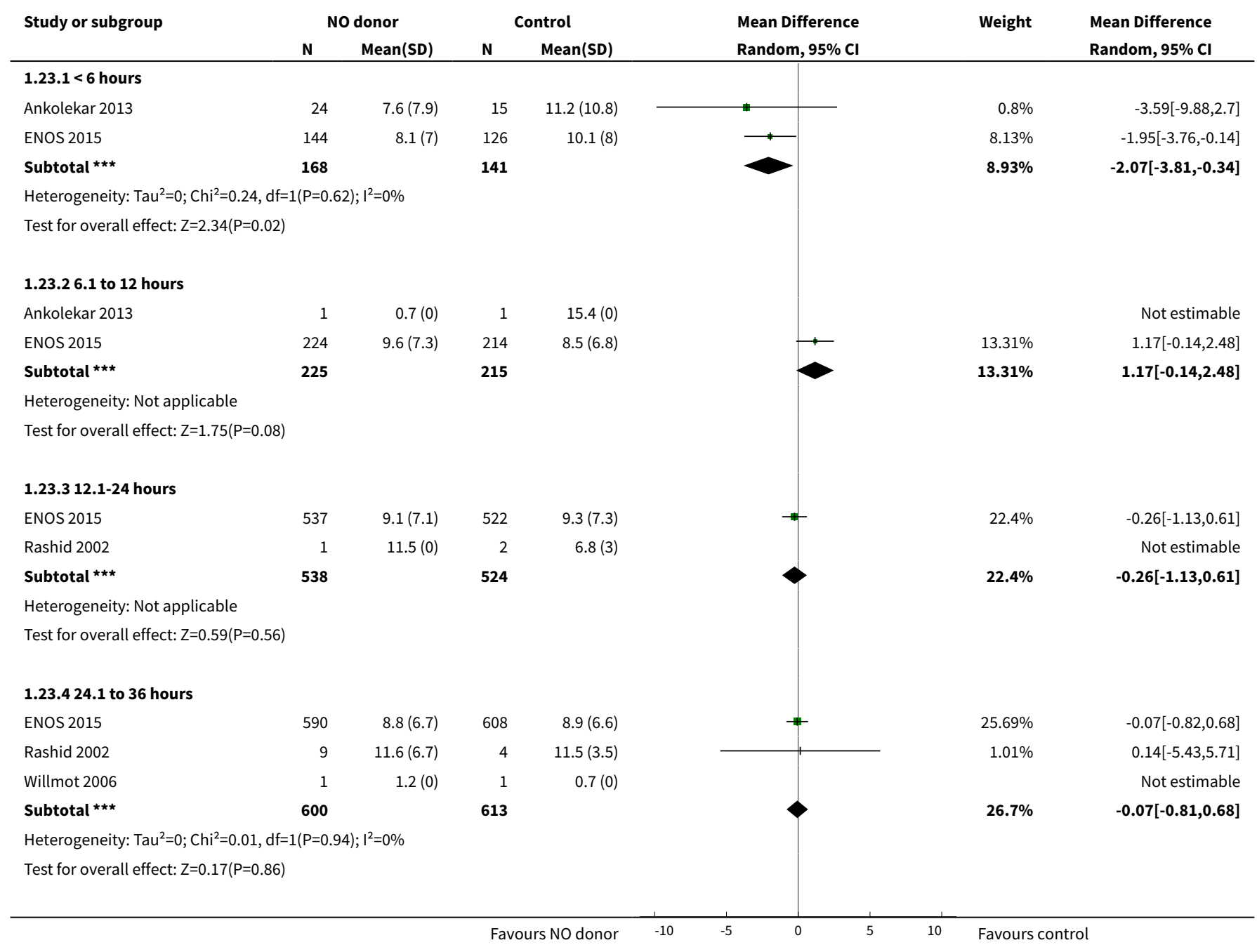




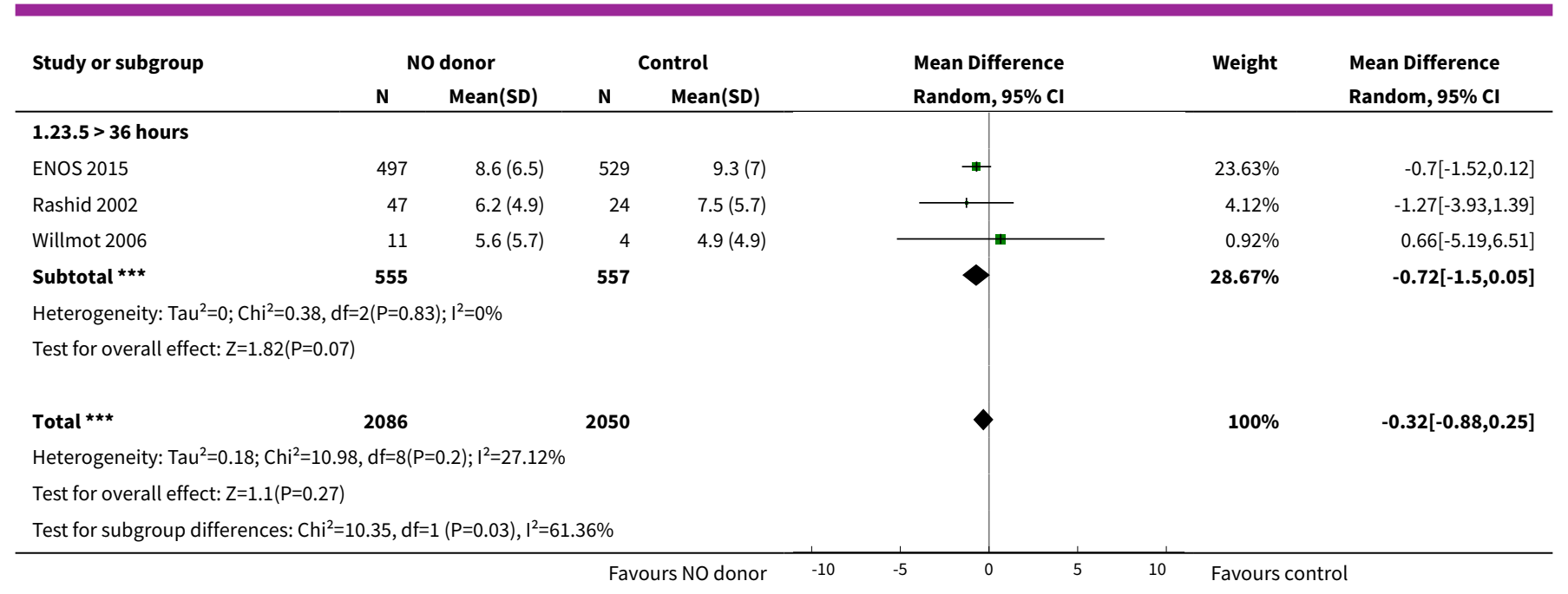

\section{Analysis 1.24. Comparison 1 Glyceryl trinitrate (GTN) compared with no GTN for acute stroke, Outcome 24 NIH Stroke Scale, end of treatment, by baseline SBP.}

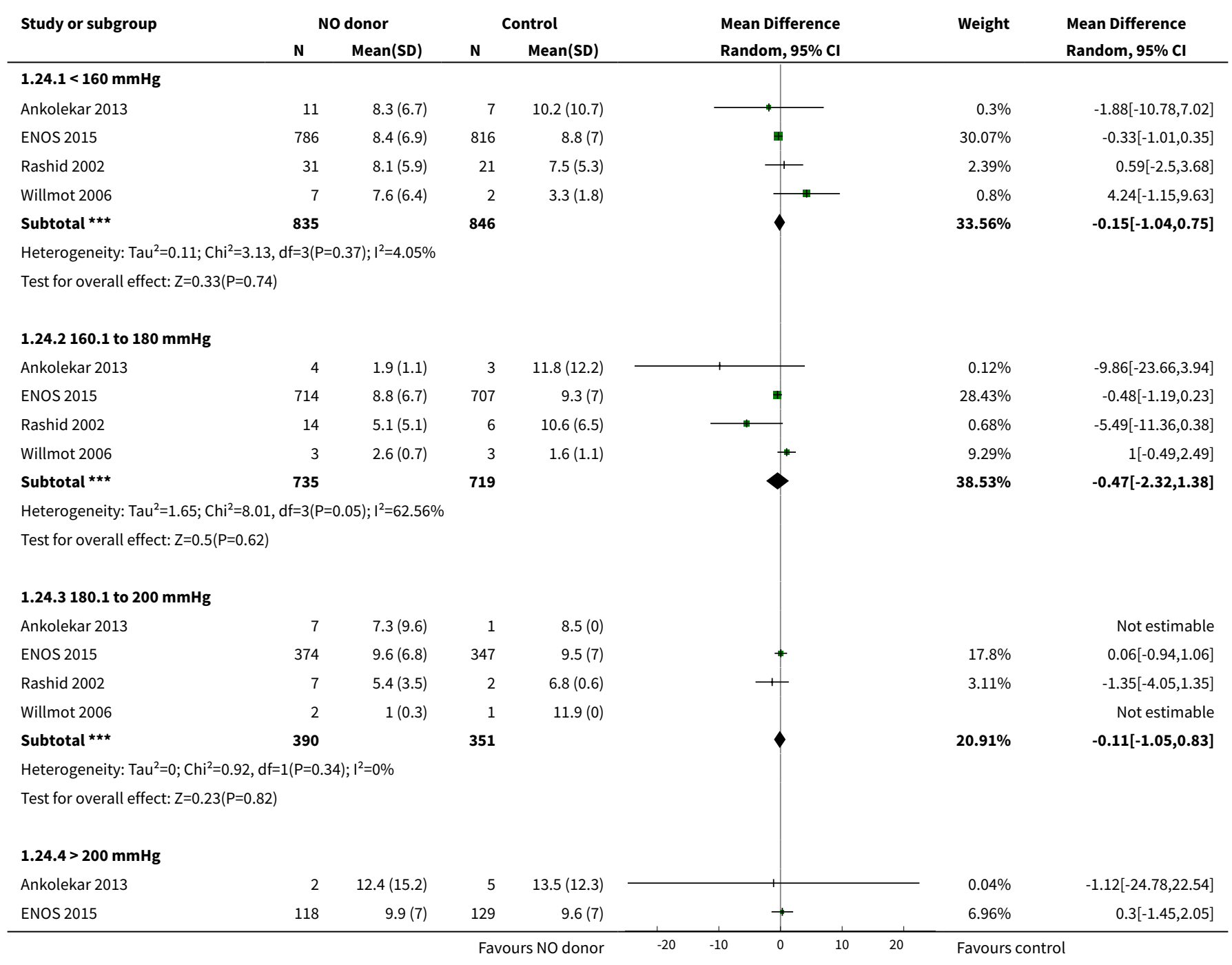




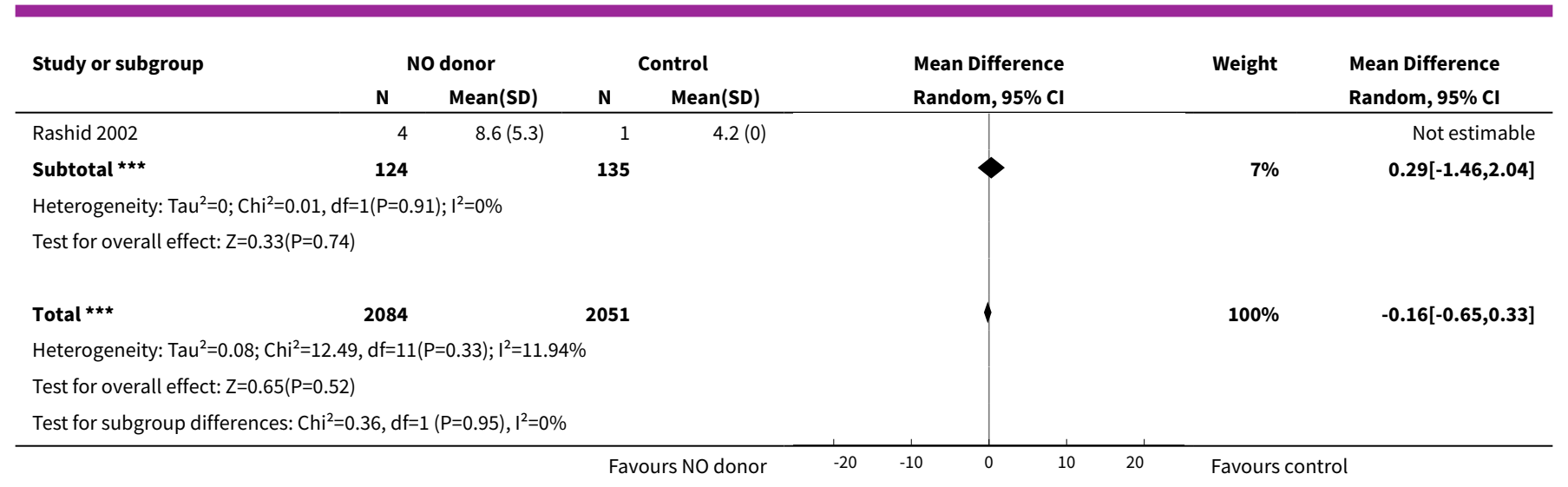

Analysis 1.25. Comparison 1 Glyceryl trinitrate (GTN) compared with no GTN for acute stroke, Outcome 25 Barthel Index, end of trial.

\begin{tabular}{|c|c|c|c|c|c|c|c|}
\hline \multirow[t]{2}{*}{ Study or subgroup } & \multicolumn{2}{|c|}{ NO donor } & \multicolumn{2}{|c|}{ Control } & \multirow{2}{*}{$\begin{array}{l}\text { Mean Difference } \\
\text { Random, } 95 \% \mathrm{Cl}\end{array}$} & \multirow[t]{2}{*}{ Weight } & \multirow{2}{*}{$\begin{array}{l}\text { Mean Difference } \\
\text { Random, } 95 \% \mathrm{Cl}\end{array}$} \\
\hline & $\mathbf{N}$ & Mean(SD) & $\mathbf{N}$ & Mean(SD) & & & \\
\hline \multicolumn{8}{|l|}{ 1.25.1 Overall } \\
\hline Ankolekar 2013 & 25 & $62.5(43)$ & 16 & $38.4(46.2)$ & & $3.28 \%$ & $24.06[-4.15,52.27]$ \\
\hline Bath 2001 & 16 & $9.5(9.7)$ & 18 & $14.3(7.6)$ & $\rightarrow$ & $30.31 \%$ & $-4.78[-10.69,1.13]$ \\
\hline ENOS 2015 & 1983 & $65.5(38.1)$ & 1987 & $63.3(39.4)$ & $\$$ & $44.26 \%$ & $2.18[-0.23,4.59]$ \\
\hline Rashid 2002 & 60 & $68.7(37.3)$ & 30 & $66.3(36.5)$ & $*$ & $8.83 \%$ & $2.4[-13.71,18.51]$ \\
\hline Willmot 2006 & 12 & $84.6(15.1)$ & 6 & $89.2(11.1)$ & - & $13.32 \%$ & $-4.59[-16.95,7.77]$ \\
\hline Subtotal $\star \star \star$ & 2096 & & 2057 & & & $100 \%$ & $-0.09[-5.39,5.2]$ \\
\hline \multicolumn{8}{|c|}{ Heterogeneity: $\mathrm{Tau}^{2}=14.95 ; \mathrm{Chi}^{2}=7.95, \mathrm{df}=4(\mathrm{P}=0.09) ; \mathrm{I}^{2}=49.68 \%$} \\
\hline \multicolumn{8}{|c|}{ Test for overall effect: $Z=0.03(P=0.97)$} \\
\hline Total $\star \star \star ~$ & 2096 & & 2057 & & & $100 \%$ & $-0.09[-5.39,5.2]$ \\
\hline \multicolumn{8}{|c|}{ Heterogeneity: $\mathrm{Tau}^{2}=14.95 ; \mathrm{Chi}^{2}=7.95, \mathrm{df}=4(\mathrm{P}=0.09) ; \mathrm{I}^{2}=49.68 \%$} \\
\hline
\end{tabular}

Analysis 1.26. Comparison 1 Glyceryl trinitrate (GTN) compared with no GTN for acute stroke, Outcome 26 Barthel Index, end of trial, by stroke type.

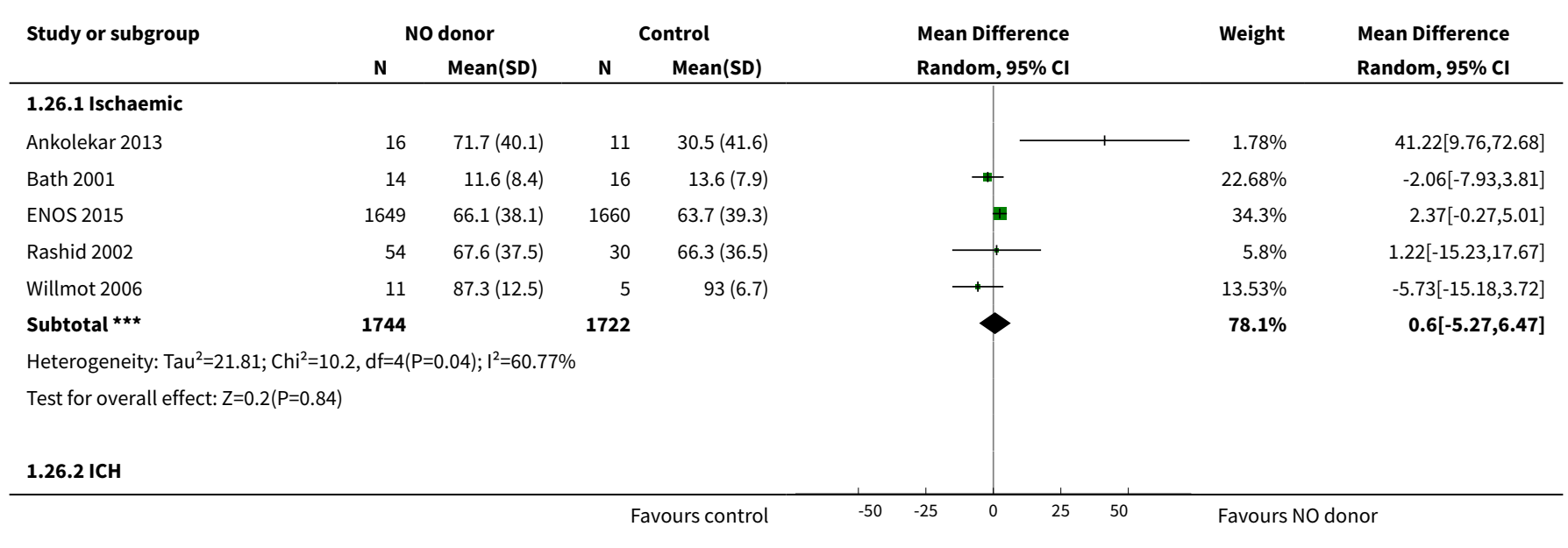




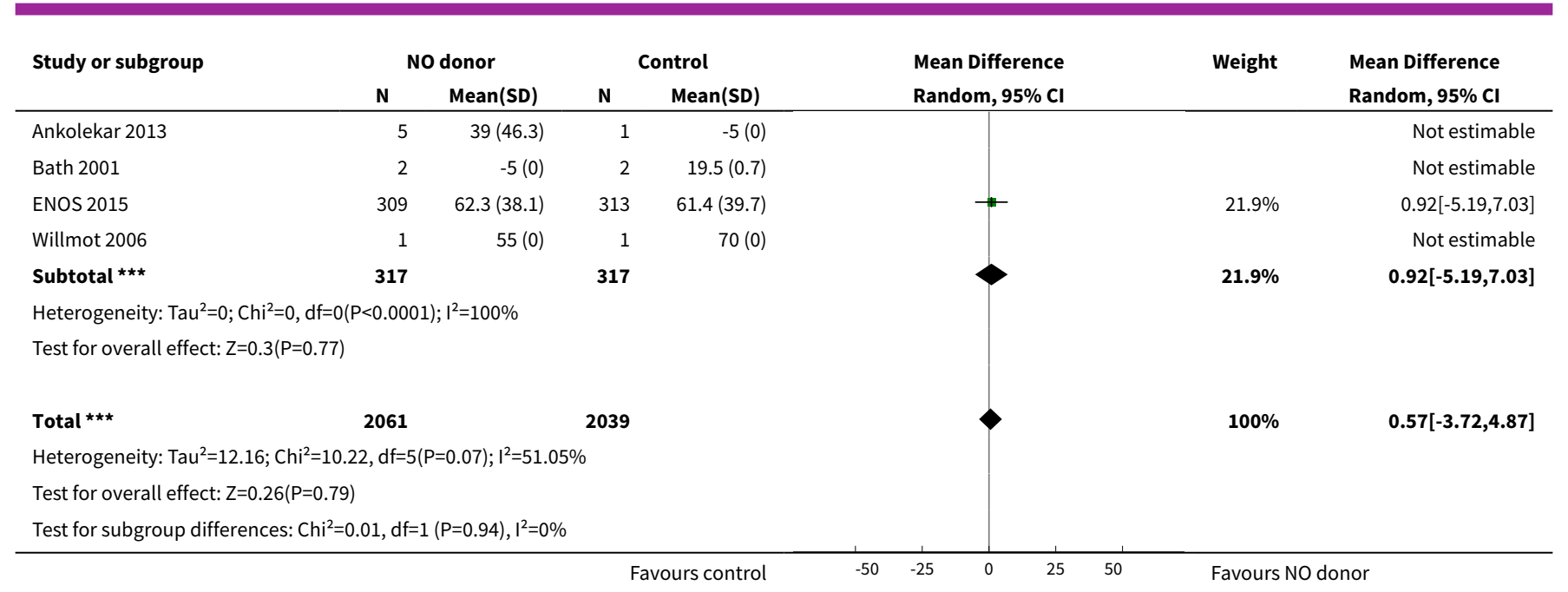

Analysis 1.27. Comparison 1 Glyceryl trinitrate (GTN) compared with no GTN for
acute stroke, Outcome 27 Barthel Index, end of trial, by time to randomisation.

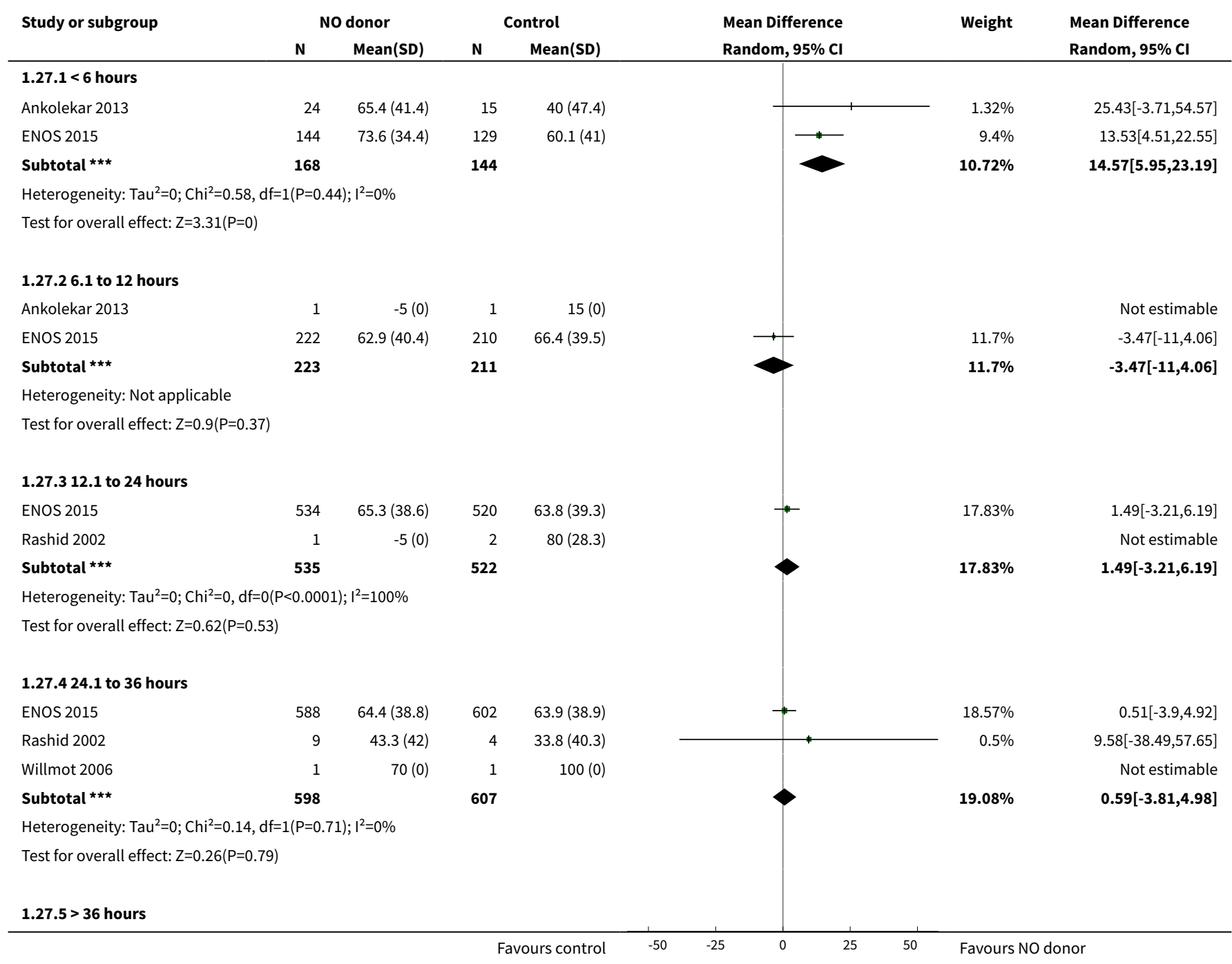




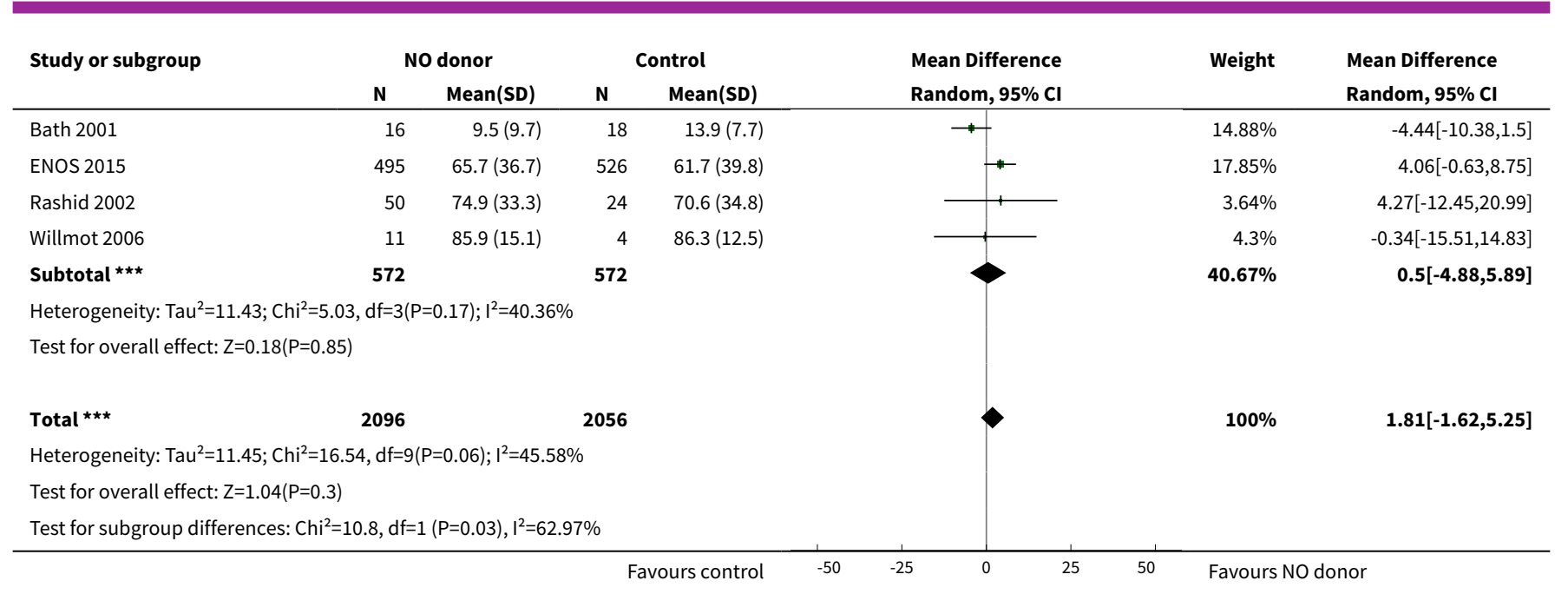

\section{Analysis 1.28. Comparison 1 Glyceryl trinitrate (GTN) compared with no GTN for acute stroke, Outcome 28 Barthel Index, end of trial, by baseline SBP.}

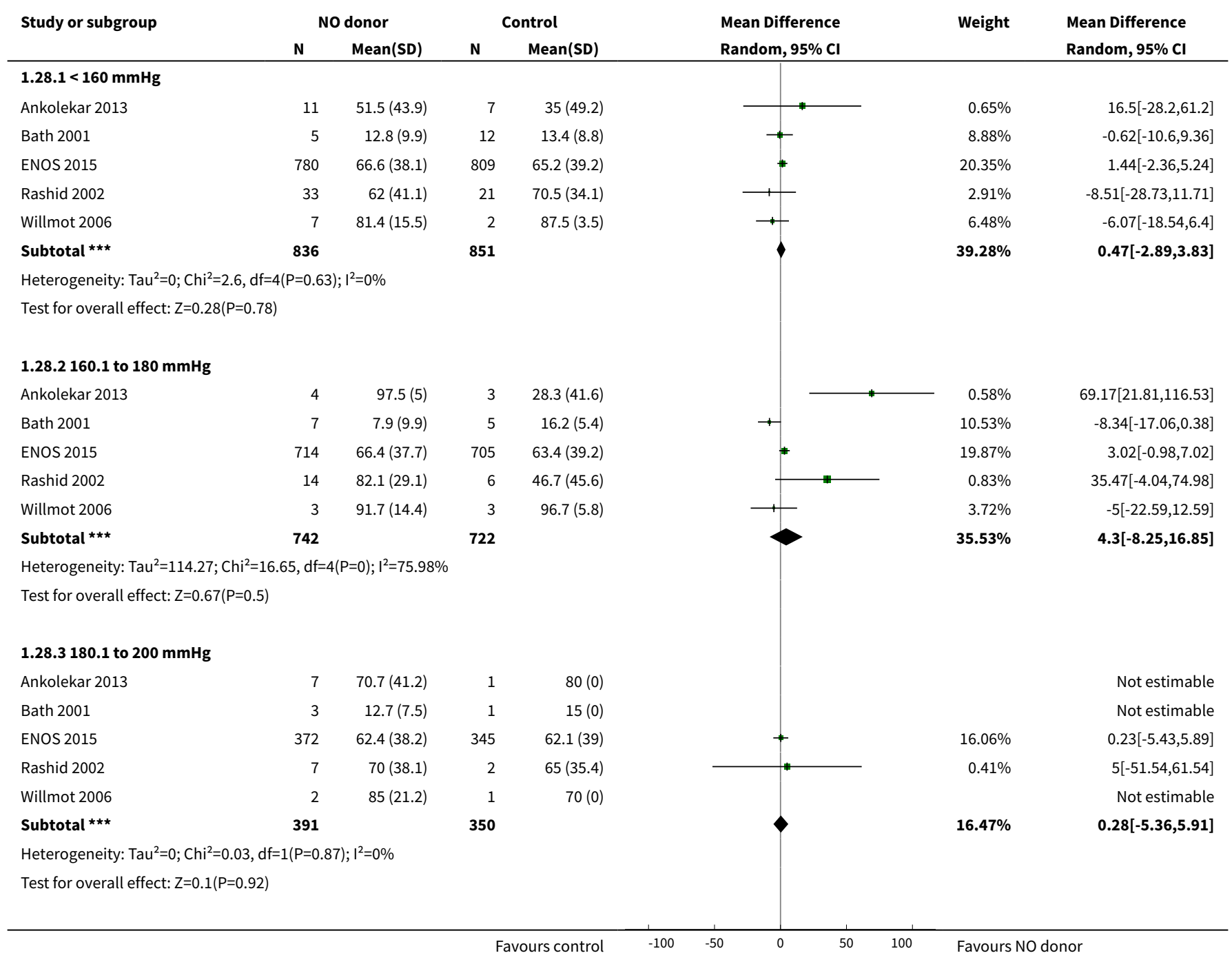




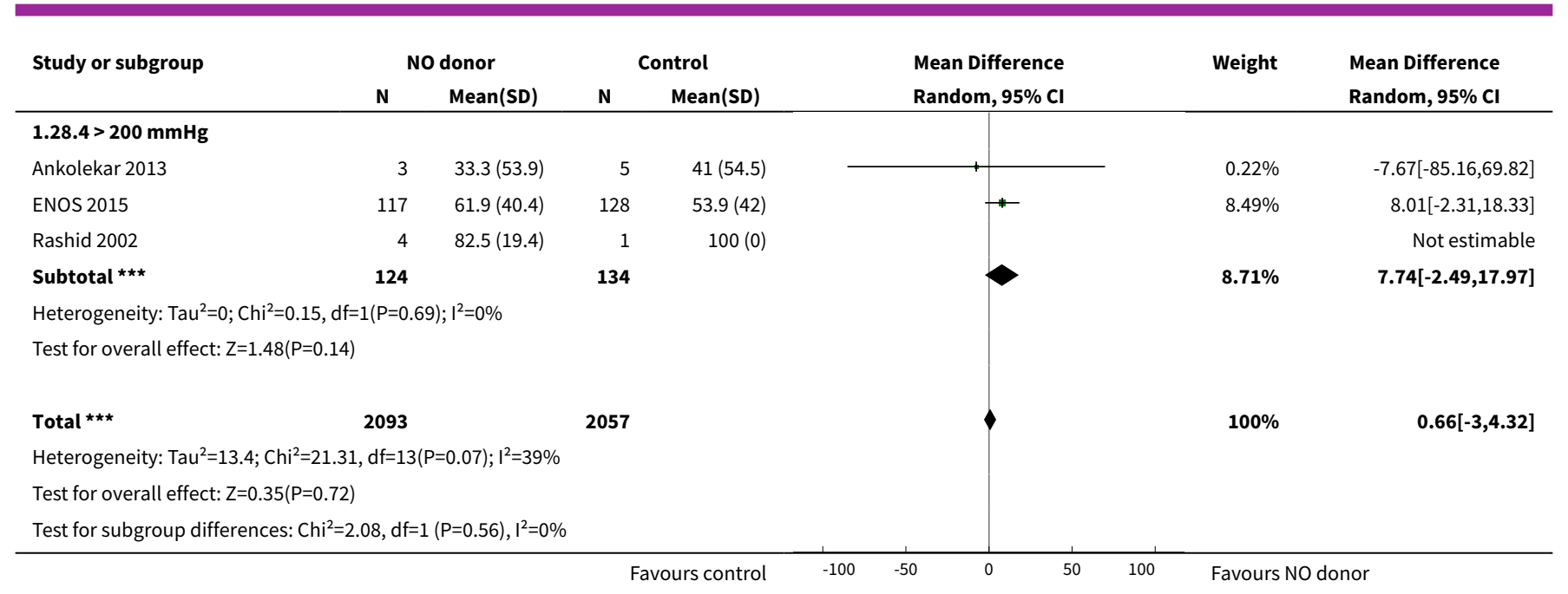

Analysis 1.29. Comparison 1 Glyceryl trinitrate (GTN) compared with no GTN for acute stroke, Outcome 29 Mood (Zung), end of trial.

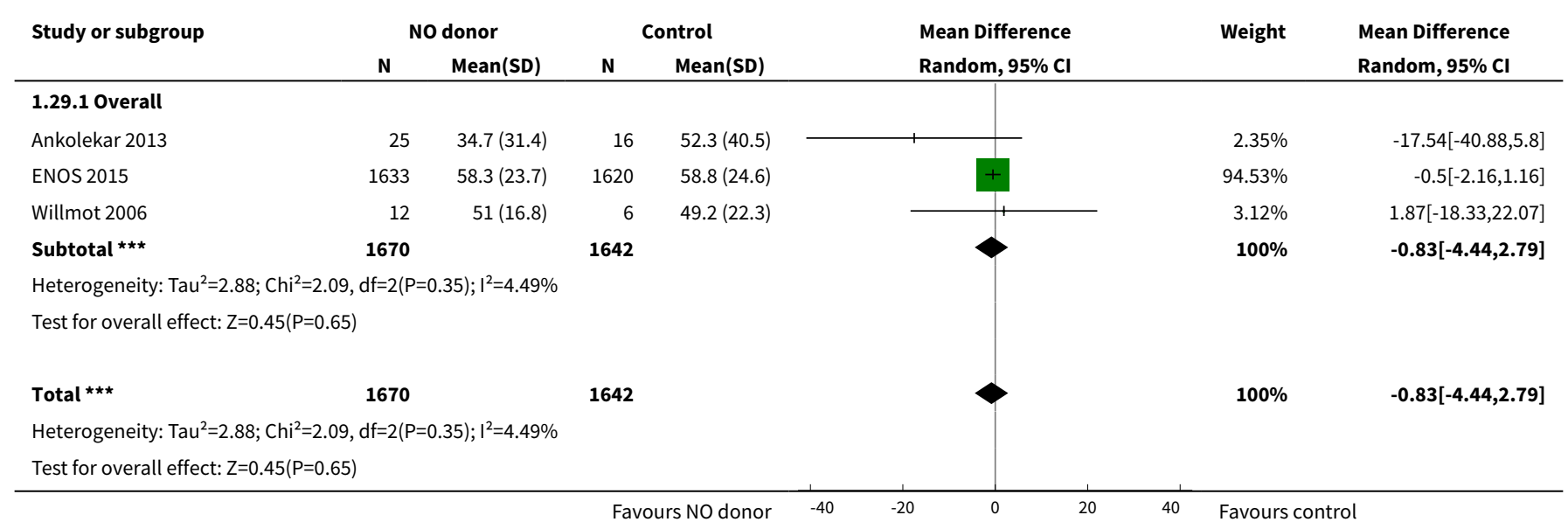

Analysis 1.30. Comparison 1 Glyceryl trinitrate (GTN) compared with no GTN for acute stroke, Outcome $30 \mathrm{Mood}$ (Zung), end of trial, by stroke type.

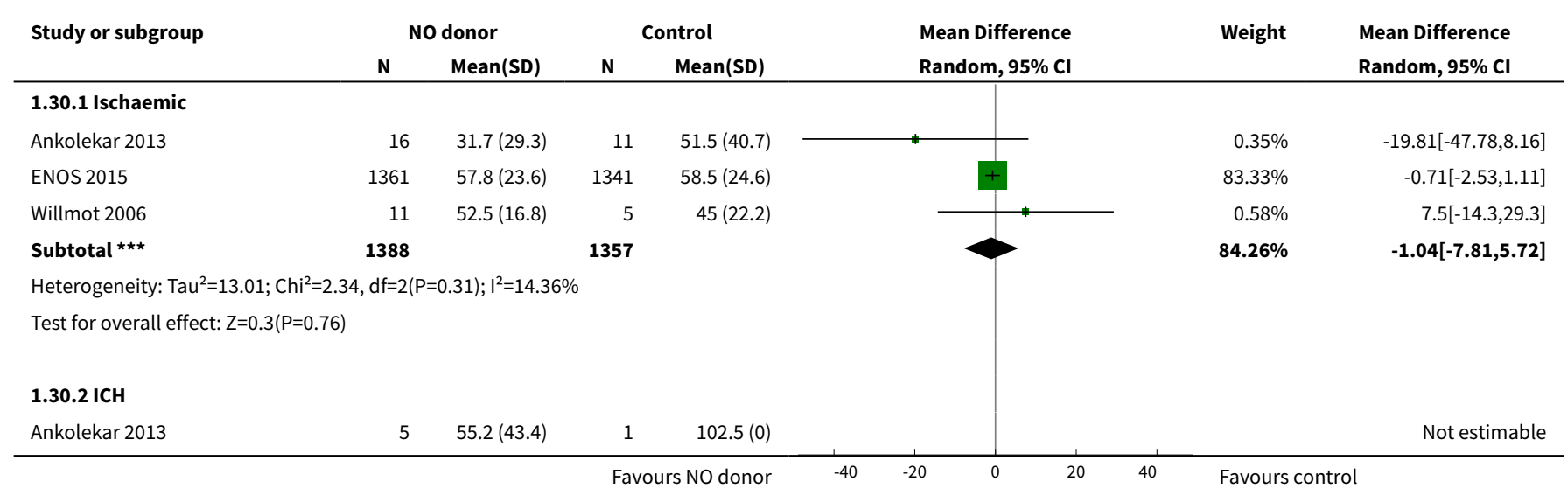




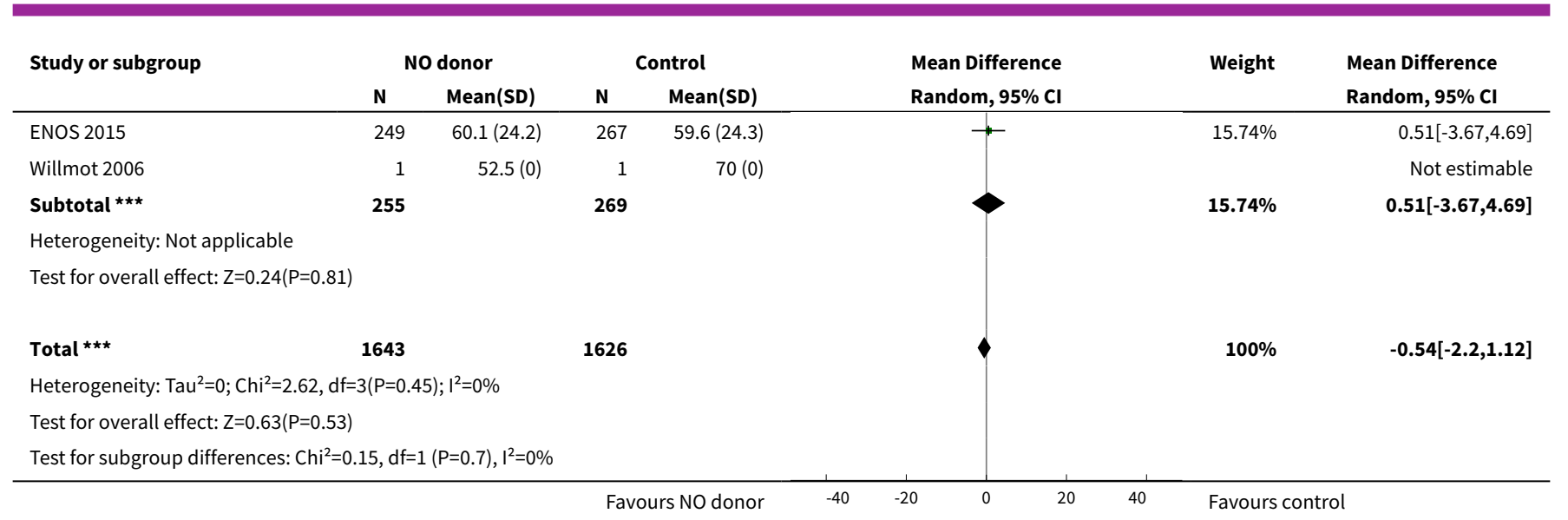

Analysis 1.31. Comparison 1 Glyceryl trinitrate (GTN) compared with no GTN for acute stroke, Outcome 31 Mood (Zung), end of trial, by time to randomisation.

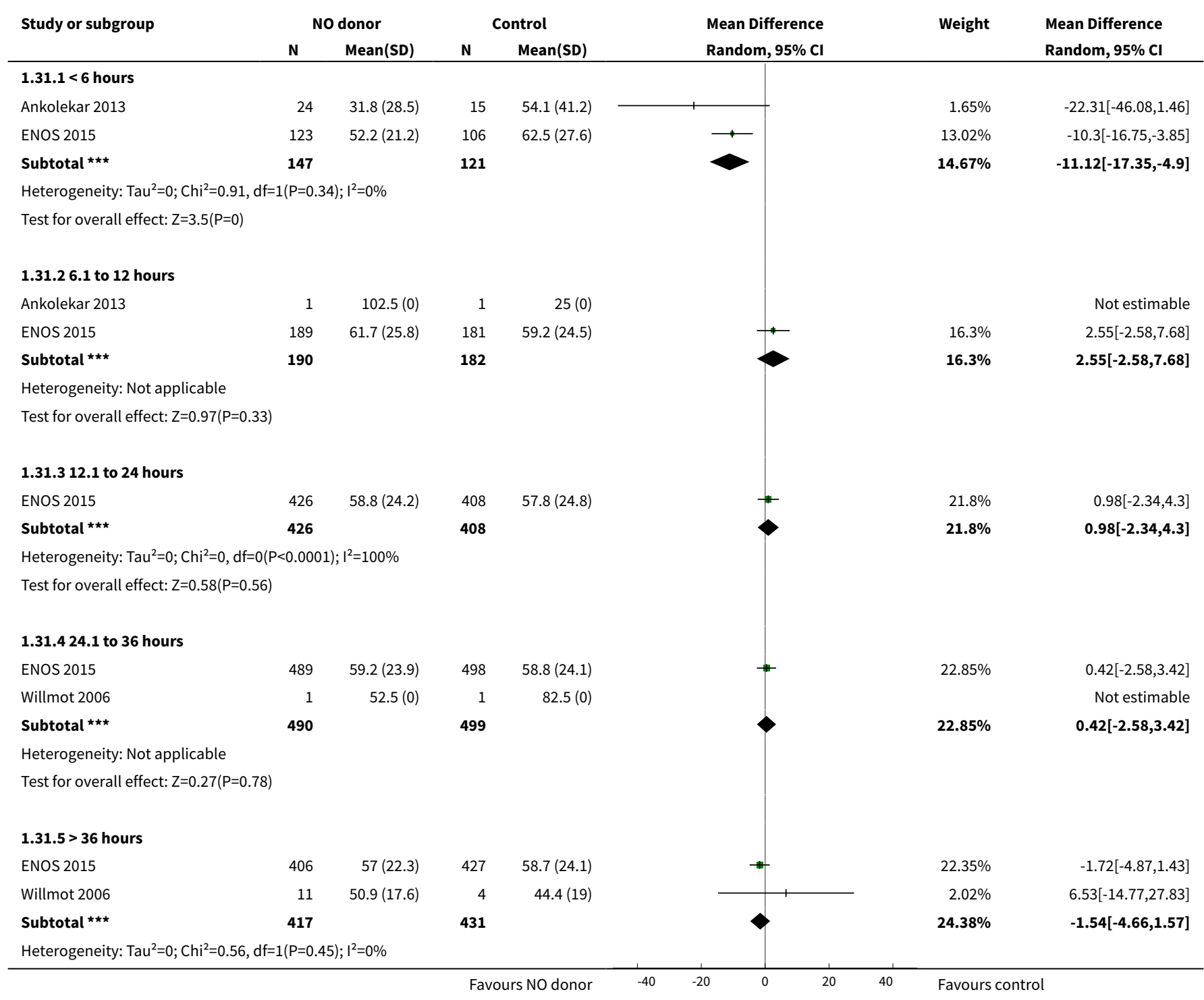




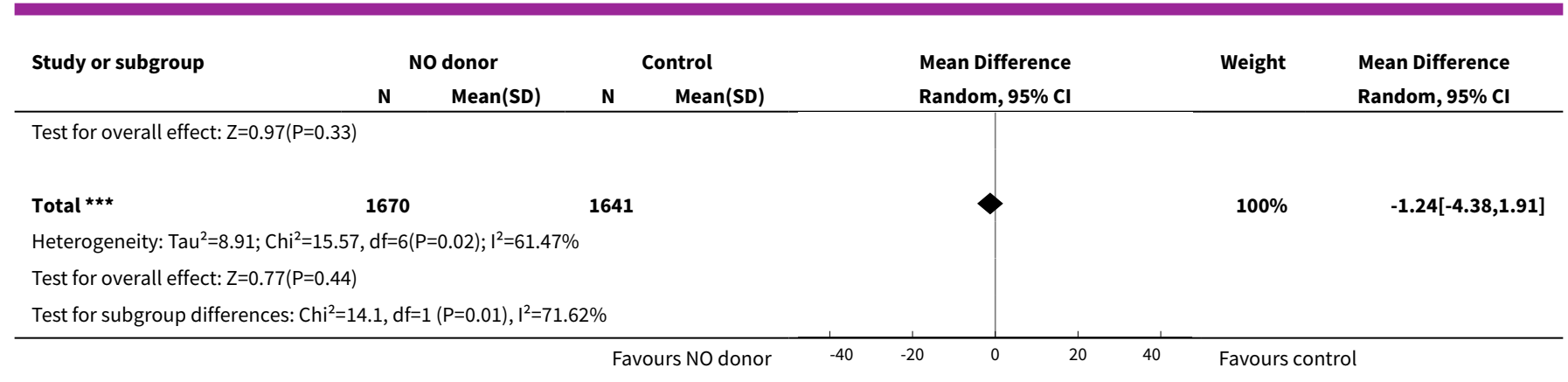

\section{Analysis 1.32. Comparison 1 Glyceryl trinitrate (GTN) compared with no GTN for acute stroke, Outcome 32 Mood (Zung), end of trial, by baseline SBP.}

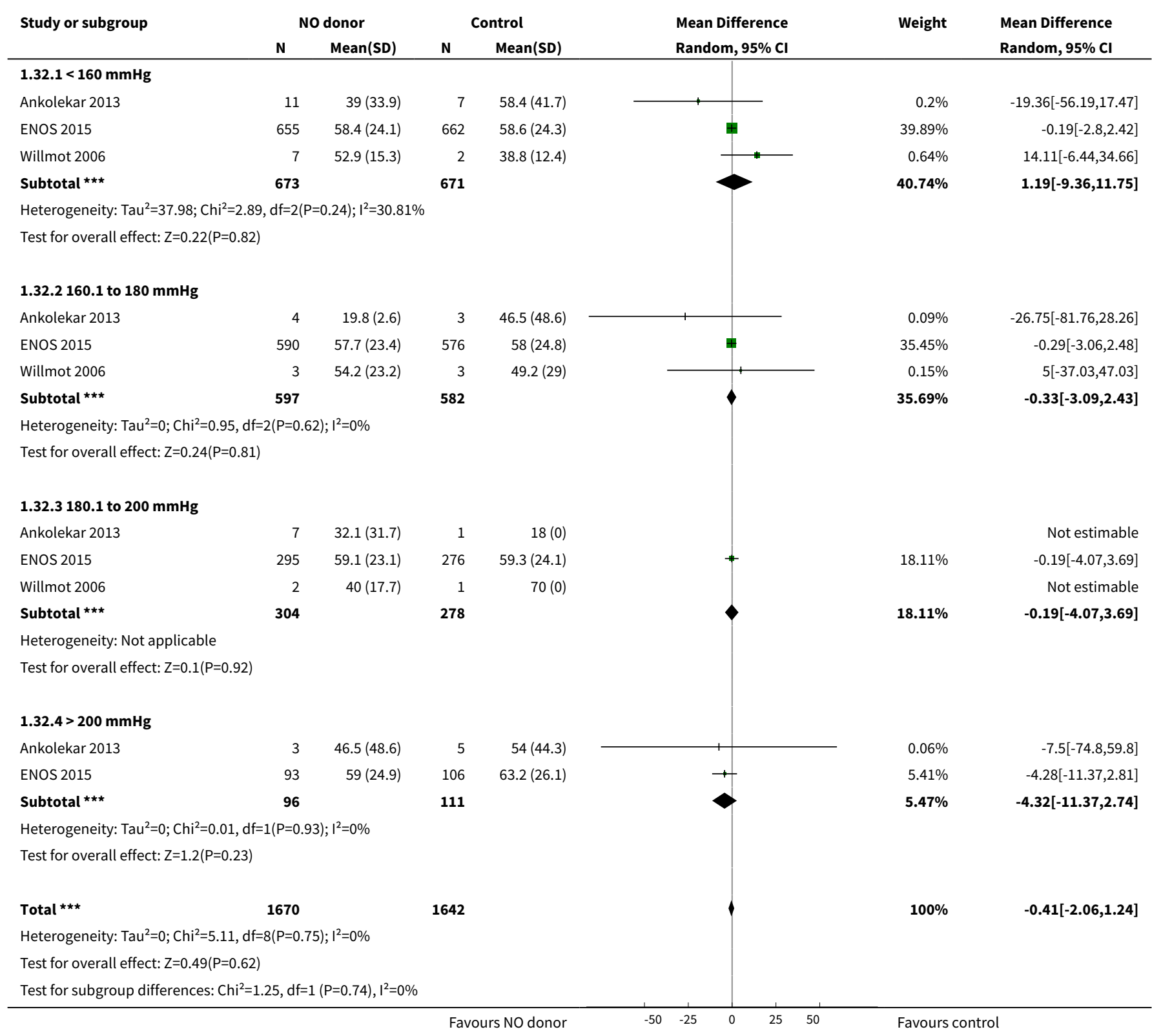




\section{Analysis 1.33. Comparison 1 Glyceryl trinitrate (GTN) compared} with no GTN for acute stroke, Outcome 33 EQ5D-3L, end of trial.

\begin{tabular}{|c|c|c|c|c|c|c|c|}
\hline \multirow[t]{2}{*}{ Study or subgroup } & \multicolumn{2}{|c|}{ NO donor } & \multicolumn{2}{|c|}{ Control } & \multirow{2}{*}{$\begin{array}{l}\text { Mean Difference } \\
\text { Random, 95\% Cl }\end{array}$} & \multirow[t]{2}{*}{ Weight } & \multirow{2}{*}{$\begin{array}{l}\text { Mean Difference } \\
\text { Random, } 95 \% \mathrm{Cl}\end{array}$} \\
\hline & $\mathbf{N}$ & Mean(SD) & $\mathbf{N}$ & $\operatorname{Mean}(S D)$ & & & \\
\hline \multicolumn{8}{|l|}{ 1.33.1 Overall } \\
\hline Ankolekar 2013 & 25 & $0.5(0.3)$ & 16 & $0.3(0.3)$ & $\longrightarrow$ & $24.66 \%$ & $0.2[0.02,0.38]$ \\
\hline ENOS 2015 & 1978 & $0.5(0.4)$ & 1974 & $0.5(0.4)$ & 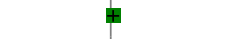 & $35.62 \%$ & $0.01[-0.01,0.03]$ \\
\hline Rashid 2002 & 54 & $0.4(0.4)$ & 28 & $0.4(0.4)$ & & $25.98 \%$ & $0.02[-0.15,0.19]$ \\
\hline Willmot 2006 & 9 & $0.4(0.5)$ & 4 & $0.9(0.1)$ & - & $13.75 \%$ & $-0.52[-0.86,-0.18]$ \\
\hline \multicolumn{8}{|c|}{ Heterogeneity: $\mathrm{Tau}^{2}=0.02 ; \mathrm{Chi}^{2}=13.49, \mathrm{df}=3(\mathrm{P}=0) ; \mathrm{I}^{2}=77.77 \%$} \\
\hline \multicolumn{8}{|c|}{ Test for overall effect: $Z=0.16(P=0.87)$} \\
\hline Total $\star \star \star ~$ & 2066 & & 2022 & & & $100 \%$ & $-0.01[-0.17,0.15]$ \\
\hline \multicolumn{8}{|c|}{ Heterogeneity: $\mathrm{Tau}^{2}=0.02 ; \mathrm{Chi}^{2}=13.49, \mathrm{df}=3(\mathrm{P}=0) ; \mathrm{I}^{2}=77.77 \%$} \\
\hline Test for overall effect & & & & & & & \\
\hline
\end{tabular}

\section{Analysis 1.34. Comparison 1 Glyceryl trinitrate (GTN) compared with no GTN for acute stroke, Outcome 34 EQ5D-3L, end of trial, by stroke type.}

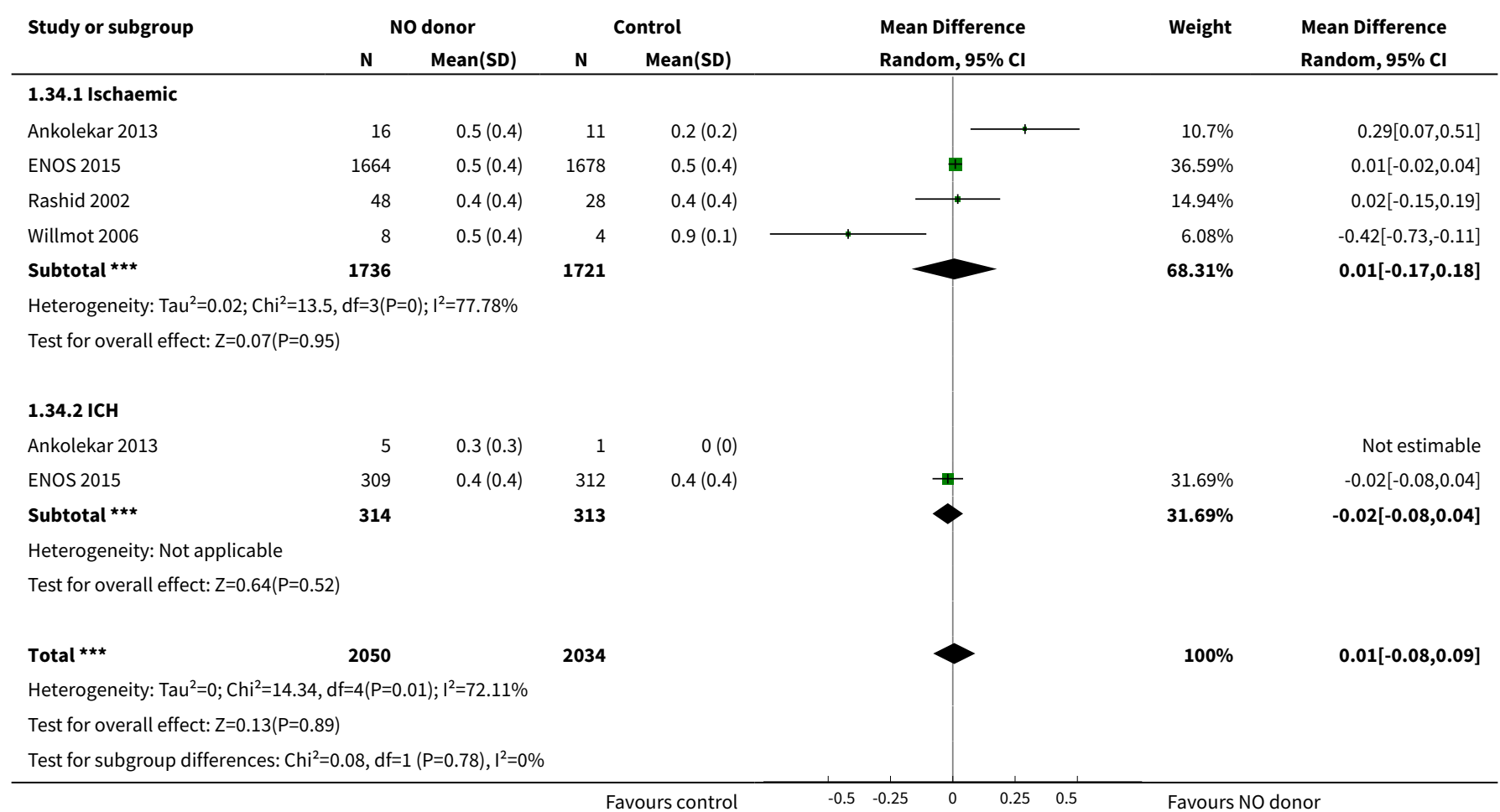


Analysis 1.35. Comparison 1 Glyceryl trinitrate (GTN) compared with no GTN for acute stroke, Outcome $35 \mathrm{EQ5D-3L}$, end of trial, by time to randomisation.

\begin{tabular}{|c|c|c|c|c|c|c|c|}
\hline \multirow{3}{*}{$\begin{array}{l}\text { Study or subgroup } \\
1.35 .1<6 \text { hours }\end{array}$} & \multicolumn{2}{|c|}{ NO donor } & \multicolumn{2}{|c|}{ Control } & \multirow{2}{*}{$\begin{array}{l}\text { Mean Difference } \\
\text { Random, } 95 \% \mathrm{Cl}\end{array}$} & \multirow[t]{2}{*}{ Weight } & \multirow{2}{*}{$\begin{array}{l}\text { Mean Difference } \\
\text { Random, } 95 \% \mathrm{Cl}\end{array}$} \\
\hline & \multirow[t]{2}{*}{$\mathbf{N}$} & \multirow[t]{2}{*}{ Mean(SD) } & \multirow[t]{2}{*}{$\mathbf{N}$} & \multirow[t]{2}{*}{ Mean(SD) } & & & \\
\hline & & & & & & & \\
\hline Ankolekar 2013 & 24 & $0.5(0.4)$ & 15 & $0.2(0.3)$ & 1 & $4.16 \%$ & $0.21[-0,0.42]$ \\
\hline ENOS 2015 & 144 & $0.5(0.4)$ & 129 & $0.4(0.4)$ & 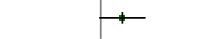 & $12.28 \%$ & $0.09[-0.01,0.19]$ \\
\hline 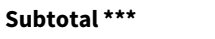 & 168 & & 144 & & & $16.43 \%$ & $0.11[0.02,0.2]$ \\
\hline \multicolumn{8}{|c|}{ Heterogeneity: $\operatorname{Tau}^{2}=0 ; \mathrm{Chi}^{2}=1.03, \mathrm{df}=1(\mathrm{P}=0.31) ; \mathrm{I}^{2}=2.52 \%$} \\
\hline \multicolumn{8}{|c|}{ 1.35.2 6.1 to 12 hours } \\
\hline Ankolekar 2013 & 1 & $0(0)$ & 1 & $-0.2(0)$ & & & Not estimable \\
\hline ENOS 2015 & 223 & $0.5(0.4)$ & 210 & $0.5(0.4)$ & $\rightarrow$ & $15.31 \%$ & $-0.04[-0.12,0.04]$ \\
\hline 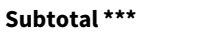 & 224 & & 211 & & & $15.31 \%$ & $-0.04[-0.12,0.04]$ \\
\hline \multicolumn{8}{|c|}{ Heterogeneity: Not applicable } \\
\hline \multicolumn{8}{|c|}{ 1.35.3 12.1 to 24 hours } \\
\hline ENOS 2015 & 530 & $0.4(0.4)$ & 519 & $0.5(0.4)$ & 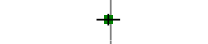 & $19.78 \%$ & $-0.01[-0.06,0.04]$ \\
\hline Rashid 2002 & 1 & $0(0)$ & 2 & $0.4(0.4)$ & & & Not estimable \\
\hline Subtotal $* \star \star$ & 531 & & 521 & & & $19.78 \%$ & $-0.01[-0.06,0.04]$ \\
\hline \multicolumn{8}{|c|}{ Heterogeneity: Not applicable } \\
\hline \multicolumn{8}{|c|}{ Test for overall effect: $Z=0.4(P=0.69)$} \\
\hline \multicolumn{8}{|c|}{ 1.35.4 24.1 to 36 hours } \\
\hline ENOS 2015 & 587 & $0.5(0.4)$ & 597 & $0.5(0.4)$ & + & $20.37 \%$ & $0.01[-0.04,0.06]$ \\
\hline Rashid 2002 & 8 & $0.2(0.4)$ & 4 & $0.2(0.4)$ & & $1.01 \%$ & $0[-0.46,0.46]$ \\
\hline Subtotal ${ }^{\star \star \star}$ & 595 & & 601 & & & $21.38 \%$ & $0.01[-0.04,0.06]$ \\
\hline \multicolumn{8}{|c|}{ Heterogeneity: $\mathrm{Tau}^{2}=0 ; \mathrm{Chi}^{2}=0, \mathrm{df}=1(\mathrm{P}=0.97) ; \mathrm{I}^{2}=0 \%$} \\
\hline \multicolumn{8}{|l|}{ 1.35.5 $>36$ hours } \\
\hline ENOS 2015 & 494 & $0.5(0.4)$ & 519 & $0.4(0.4)$ & + & $19.85 \%$ & $0.03[-0.02,0.08]$ \\
\hline Rashid 2002 & 45 & $0.5(0.4)$ & 22 & $0.5(0.3)$ & 1 & $5.53 \%$ & $0.03[-0.15,0.21]$ \\
\hline Willmot 2006 & 9 & $0.4(0.5)$ & 3 & $0.9(0.1)$ & - & $1.71 \%$ & $-0.56[-0.91,-0.21]$ \\
\hline Subtotal $* \star \star$ & 548 & & 544 & & & $27.09 \%$ & $-0.1[-0.33,0.13]$ \\
\hline \multicolumn{8}{|c|}{ Heterogeneity: $\operatorname{Tau}^{2}=0.03 ; \mathrm{Chi}^{2}=10.86, \mathrm{df}=2(\mathrm{P}=0) ; \mathrm{I}^{2}=81.59 \%$} \\
\hline \multicolumn{8}{|c|}{ Test for overall effect: $Z=0.85(P=0.4)$} \\
\hline Total $\star \star \star$ & 2066 & & 2021 & & & $100 \%$ & $0.01[-0.04,0.06]$ \\
\hline \multicolumn{8}{|c|}{ Heterogeneity: $\mathrm{Tau}^{2}=0 ; \mathrm{Chi}^{2}=19.44, \mathrm{df}=8(\mathrm{P}=0.01) ; \mathrm{I}^{2}=58.85 \%$} \\
\hline \multicolumn{8}{|c|}{ Test for overall effect: $Z=0.49(P=0.63)$} \\
\hline Test for subgroup dif & $91, \mathrm{df}=$ & $P=0.1), I^{2}=49$ & & & & & \\
\hline
\end{tabular}


Analysis 1.36. Comparison 1 Glyceryl trinitrate (GTN) compared with no GTN for acute stroke, Outcome 36 EQ5D-3L, end of trial, by baseline SBP.

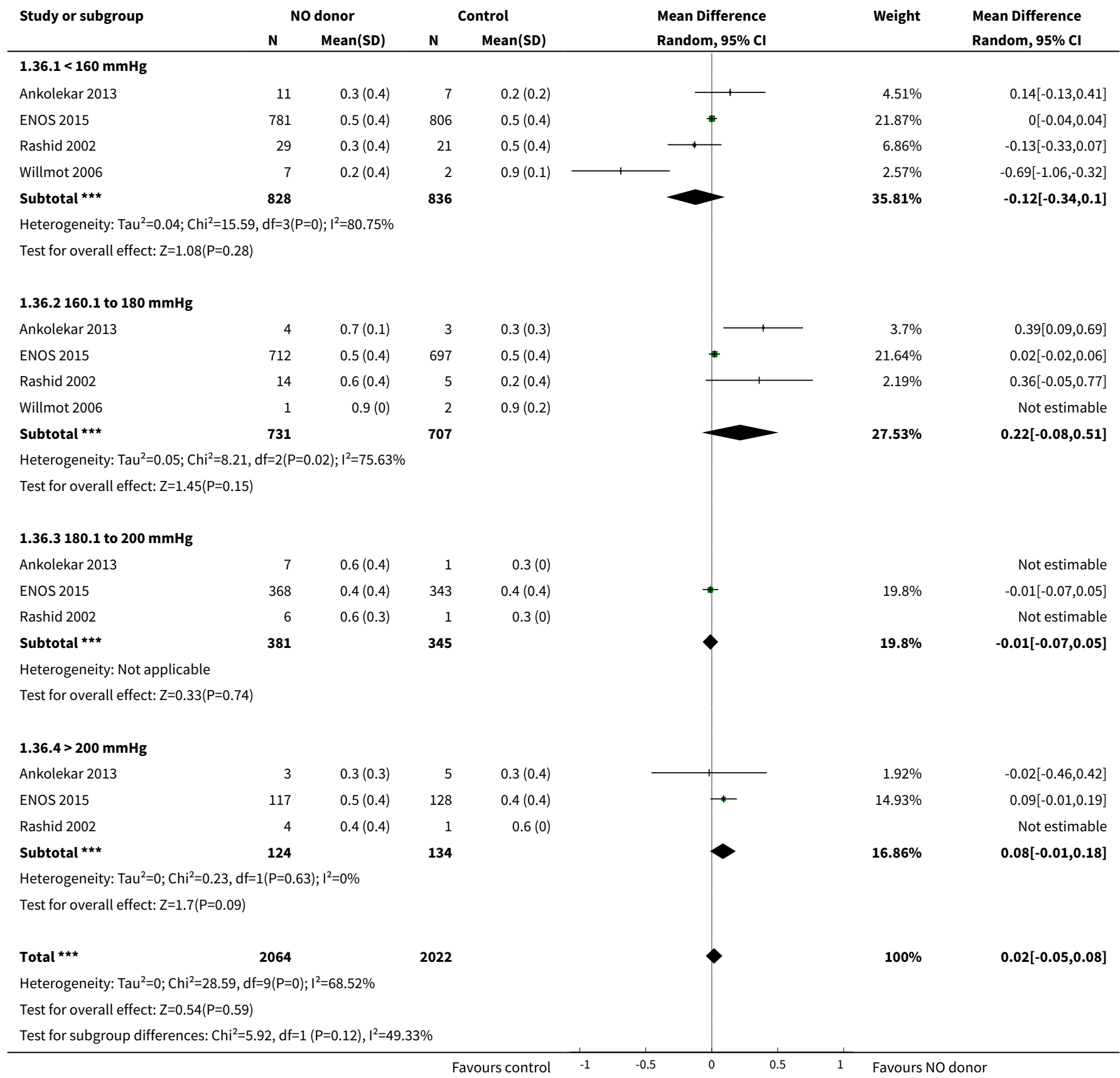

Analysis 1.37. Comparison 1 Glyceryl trinitrate (GTN) compared with no GTN for acute stroke, Outcome $37 \mathrm{EQ}$ VAS, end of trial.

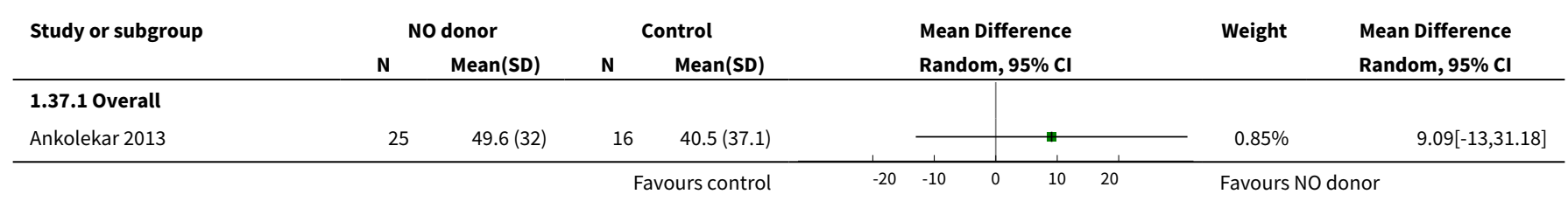




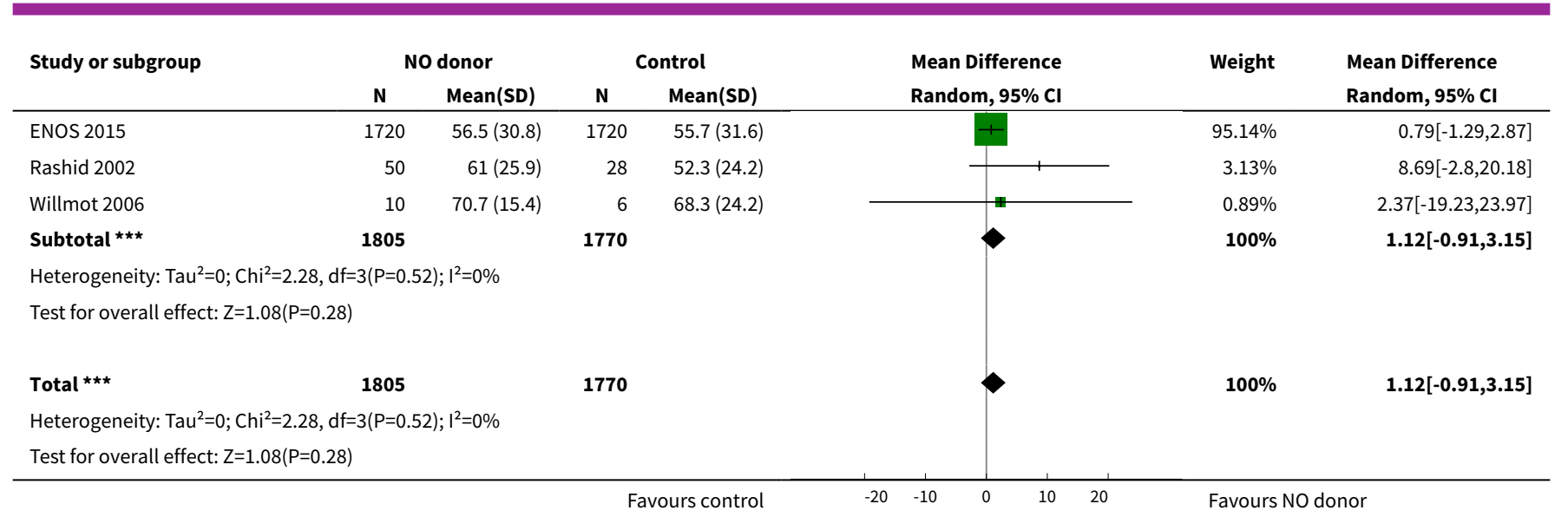

\section{Analysis 1.38. Comparison 1 Glyceryl trinitrate (GTN) compared with no} GTN for acute stroke, Outcome $38 \mathrm{EQ}$ VAS, end of trial, by stroke type.

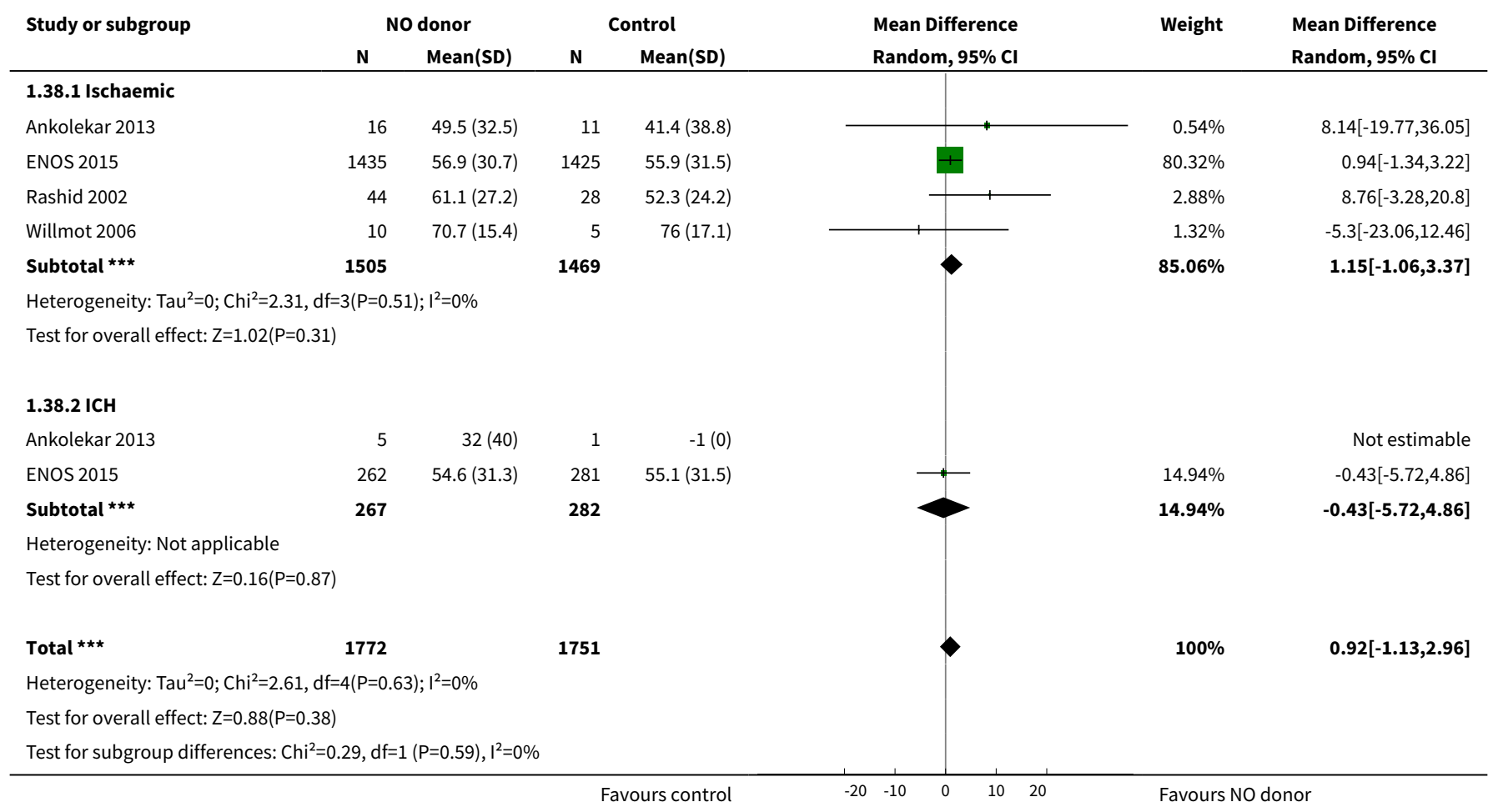

Analysis 1.39. Comparison 1 Glyceryl trinitrate (GTN) compared with no GTN for acute stroke, Outcome $39 \mathrm{EQ}$ VAS, end of trial, by time to randomisation.

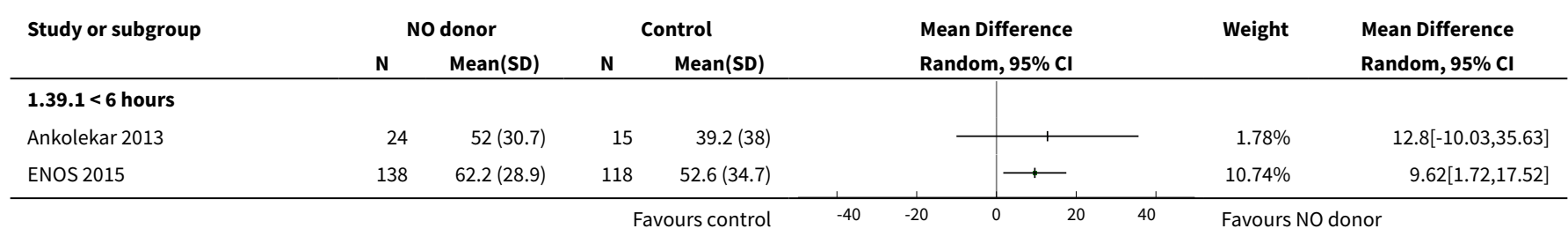




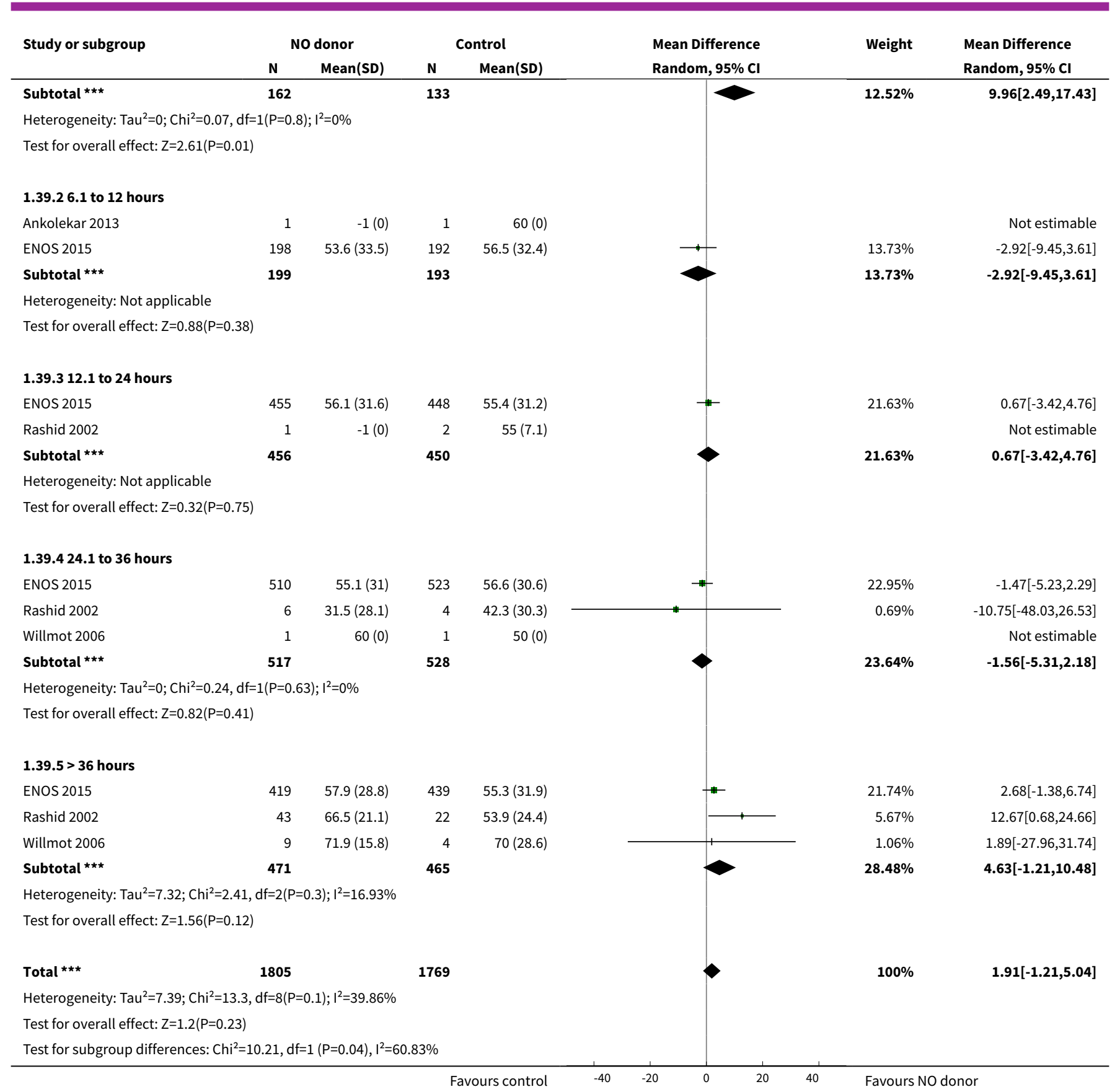

\section{Analysis 1.40. Comparison 1 Glyceryl trinitrate (GTN) compared with no} GTN for acute stroke, Outcome $40 \mathrm{EQ}$ VAS, end of trial, by baseline SBP.

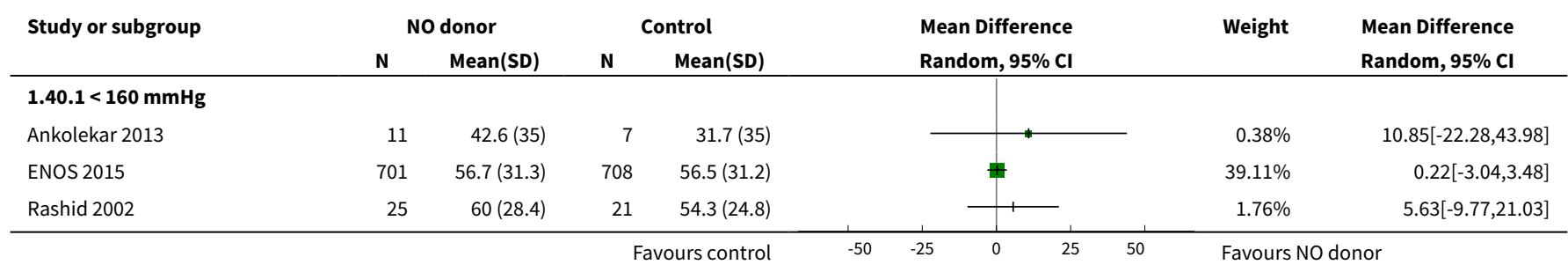




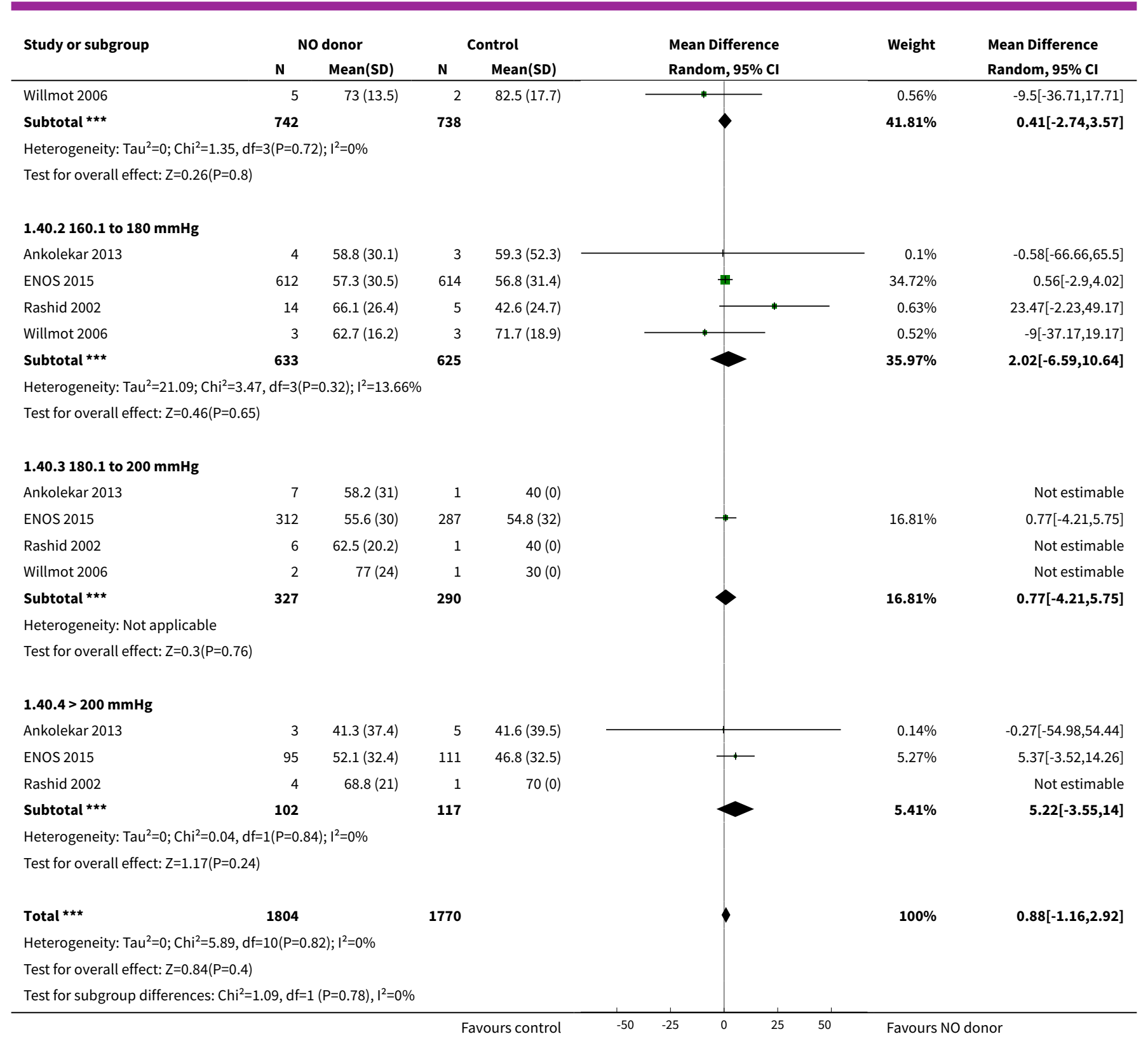

\section{Analysis 1.41. Comparison 1 Glyceryl trinitrate (GTN) compared with no GTN for acute stroke, Outcome $41 \mathrm{t}$-MMSE, end of trial.}

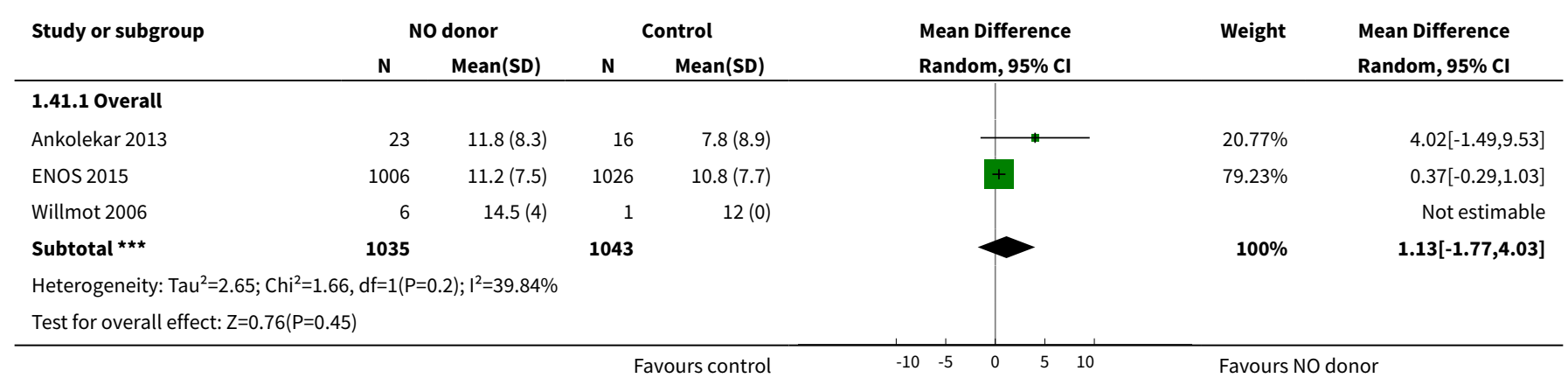




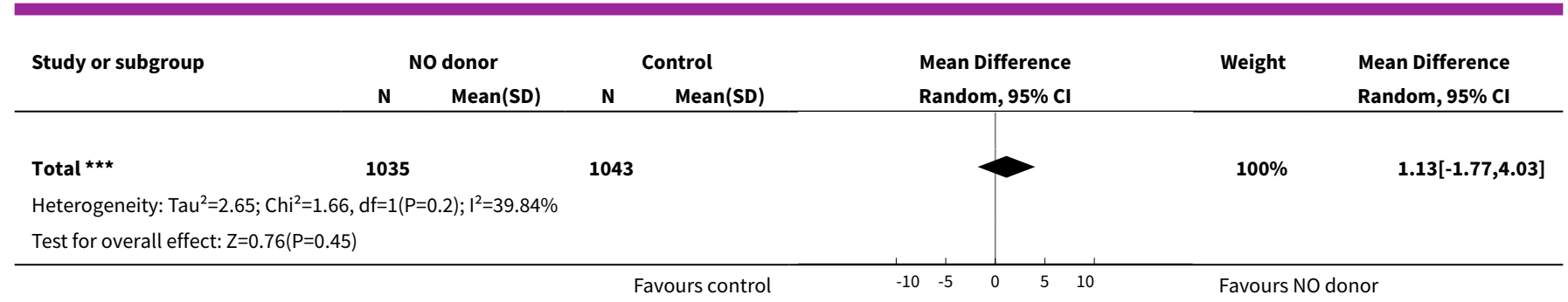

\section{Analysis 1.42. Comparison 1 Glyceryl trinitrate (GTN) compared with no} GTN for acute stroke, Outcome 42 t-MMSE, end of trial, by stroke type.

\begin{tabular}{|c|c|c|c|c|c|c|c|}
\hline \multirow[t]{2}{*}{ Study or subgroup } & \multicolumn{2}{|c|}{ NO donor } & \multicolumn{2}{|c|}{ Control } & \multirow{2}{*}{$\begin{array}{l}\text { Mean Difference } \\
\text { Random, 95\% Cl }\end{array}$} & \multirow[t]{2}{*}{ Weight } & \multirow{2}{*}{$\begin{array}{l}\text { Mean Difference } \\
\text { Random, } 95 \% \mathrm{Cl}\end{array}$} \\
\hline & $\mathbf{N}$ & Mean(SD) & $\mathbf{N}$ & Mean(SD) & & & \\
\hline \multicolumn{8}{|l|}{ 1.42.1 Ischaemic } \\
\hline Ankolekar 2013 & 14 & $14.1(7.4)$ & 11 & $6.7(8.5)$ & $\longrightarrow$ & $6.35 \%$ & $7.34[1.02,13.66]$ \\
\hline ENOS 2015 & 836 & $11.5(7.4)$ & 861 & $11(7.6)$ & + & $56.51 \%$ & $0.45[-0.26,1.16]$ \\
\hline Willmot 2006 & 6 & $14.5(4)$ & 1 & $12(0)$ & & & Not estimable \\
\hline Subtotal $\star \star \star$ & 856 & & 873 & & & $62.85 \%$ & $3.15[-3.44,9.74]$ \\
\hline \multicolumn{8}{|c|}{ Heterogeneity: $\mathrm{Tau}^{2}=18.47 ; \mathrm{Chi}^{2}=4.51, \mathrm{df}=1(\mathrm{P}=0.03) ; \mathrm{I}^{2}=77.82 \%$} \\
\hline \multicolumn{8}{|c|}{ Test for overall effect: $Z=0.94(P=0.35)$} \\
\hline \multicolumn{8}{|l|}{$1.42 .2 \mathrm{ICH}$} \\
\hline Ankolekar 2013 & 5 & $6.8(9.8)$ & 1 & $-1(0)$ & & & Not estimable \\
\hline ENOS 2015 & 153 & $10.1(7.8)$ & 153 & $10(7.9)$ & & $37.15 \%$ & $0.15[-1.61,1.91]$ \\
\hline Subtotal $\star \star \star$ & 158 & & 154 & & & $37.15 \%$ & $0.15[-1.61,1.91]$ \\
\hline \multicolumn{8}{|c|}{ Test for overall effect: $Z=0.17(P=0.87)$} \\
\hline 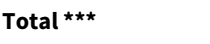 & 1014 & & 1027 & & & $100 \%$ & $0.78[-0.9,2.45]$ \\
\hline \multicolumn{8}{|c|}{ Heterogeneity: $\mathrm{Tau}^{2}=1.17 ; \mathrm{Chi}^{2}=4.67, \mathrm{df}=2(\mathrm{P}=0.1) ; \mathrm{I}^{2}=57.15 \%$} \\
\hline \multicolumn{8}{|c|}{ Test for overall effect: $Z=0.91(P=0.37)$} \\
\hline Test for subgroup dif & $74, \mathrm{df}=$ & $P=0.39), I^{2}=0 \%$ & & & & & \\
\hline
\end{tabular}

Analysis 1.43. Comparison 1 Glyceryl trinitrate (GTN) compared with no GTN for acute stroke, Outcome $43 \mathrm{t}$-MMSE, end of trial, by time to randomisation.

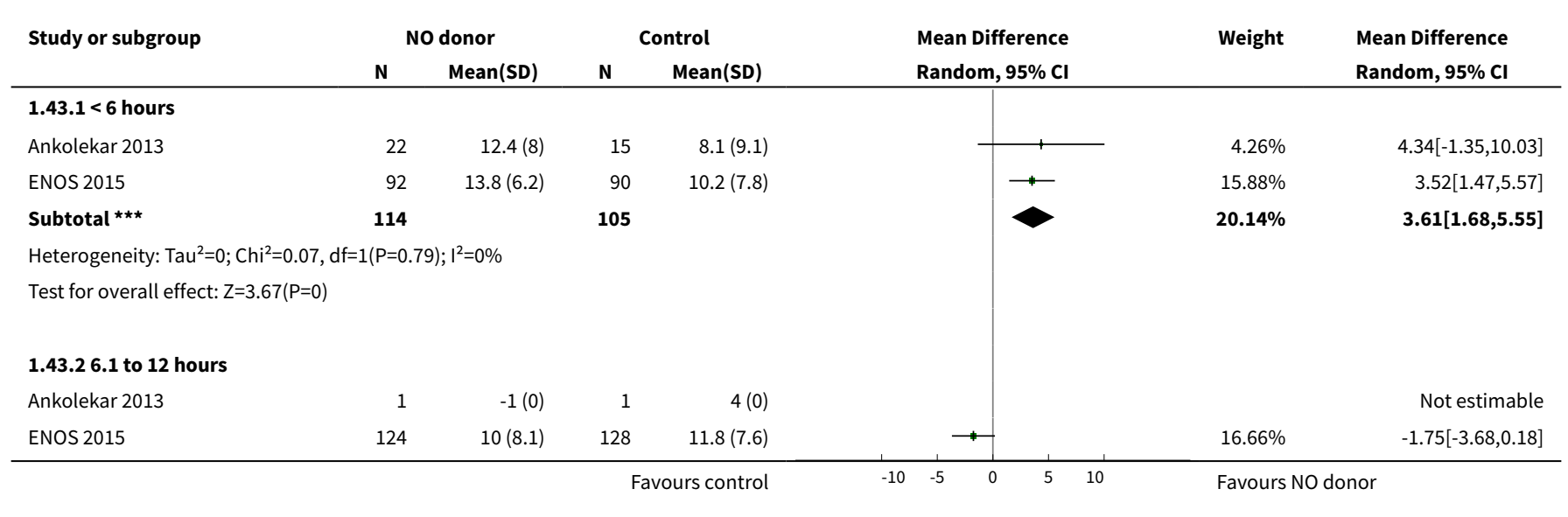




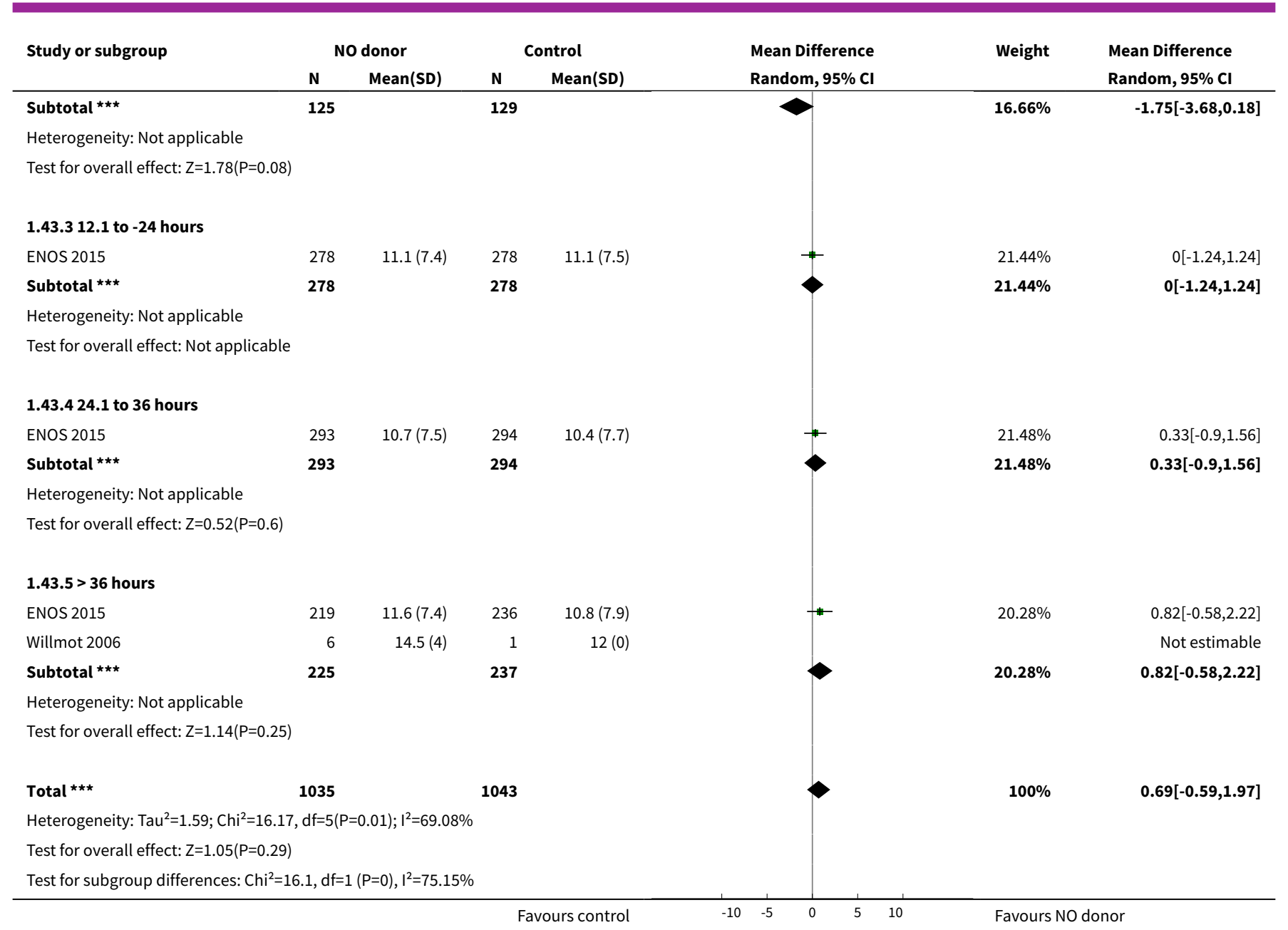

Analysis 1.44. Comparison 1 Glyceryl trinitrate (GTN) compared with no GTN for acute stroke, Outcome 44 t-MMSE, end of trial, by baseline SBP.

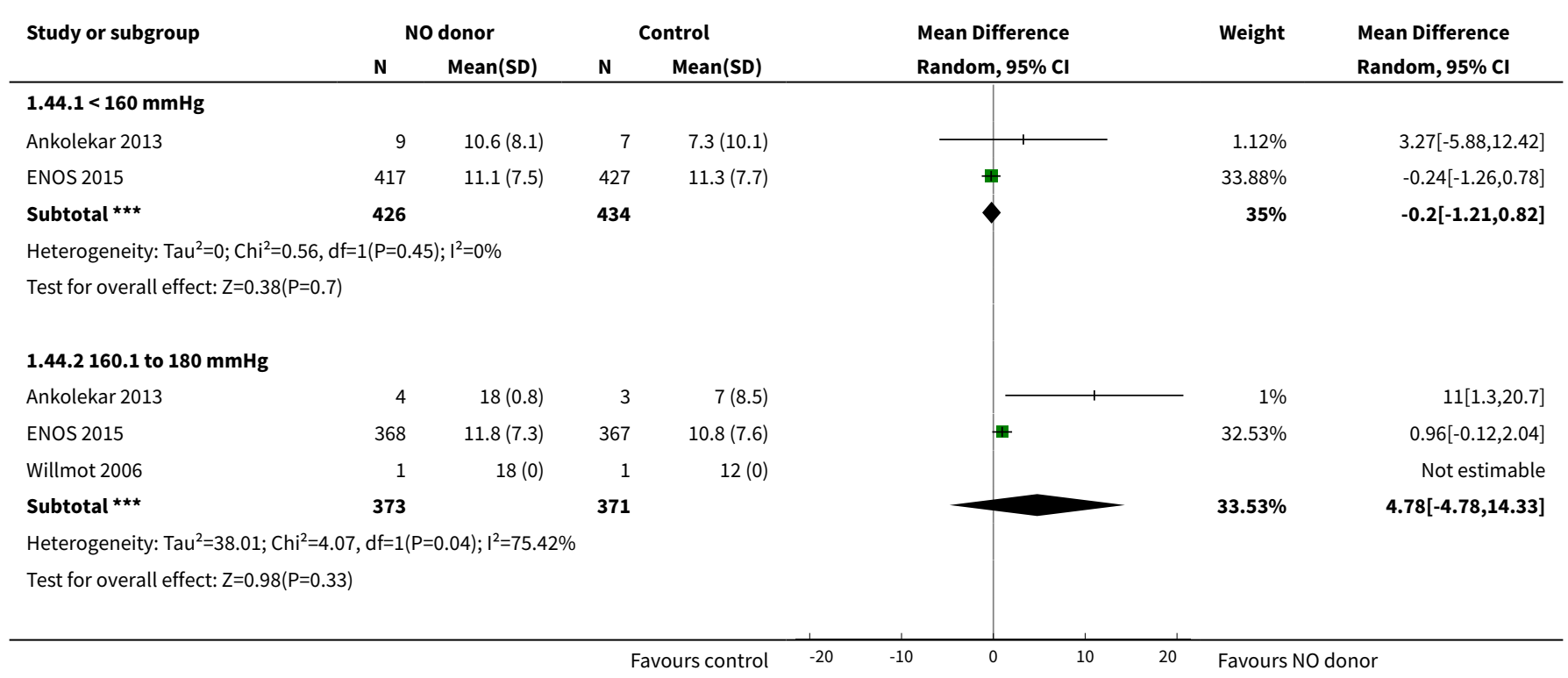




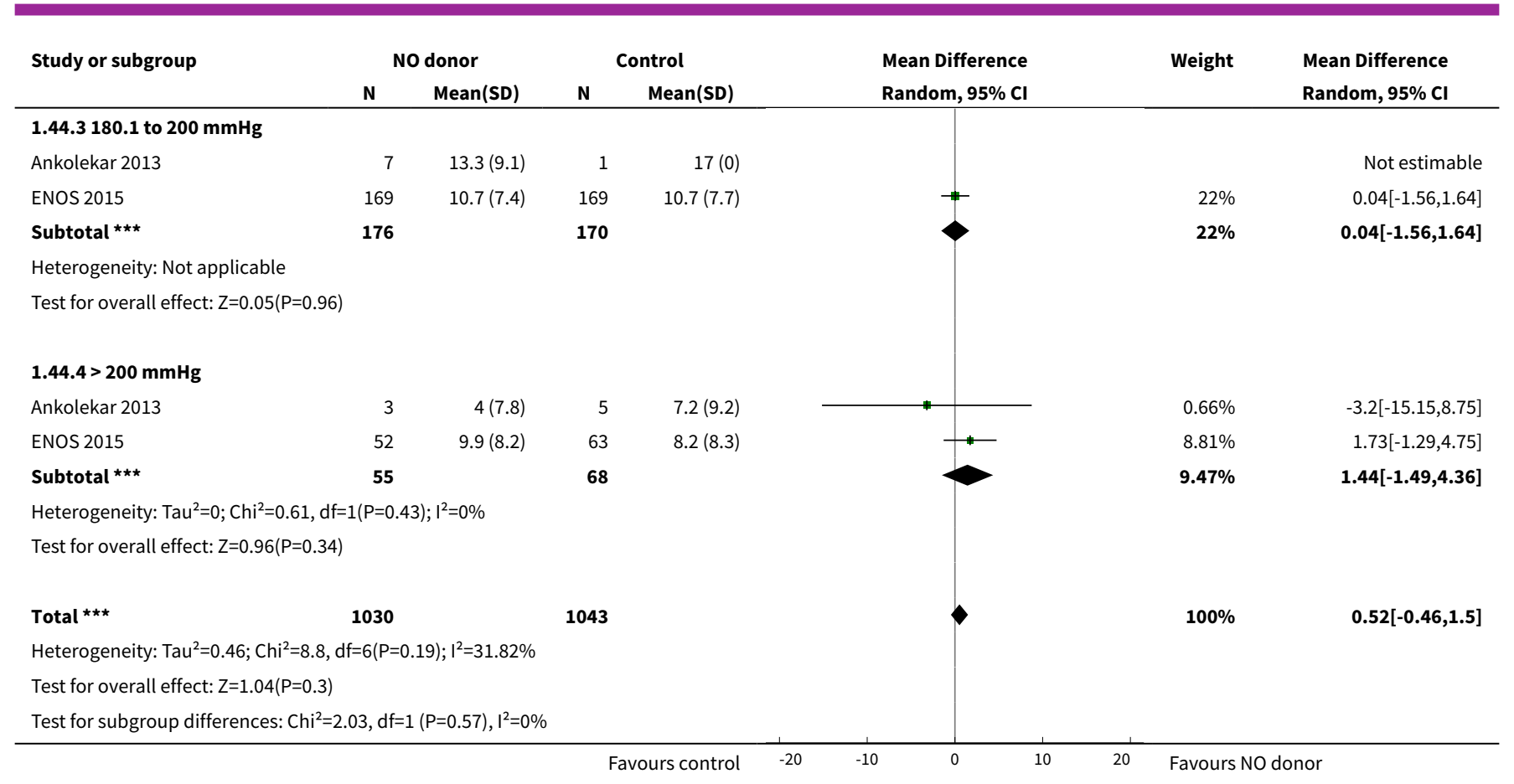

\section{Analysis 1.45. Comparison 1 Glyceryl trinitrate (GTN) compared} with no GTN for acute stroke, Outcome 45 TICS, end of trial.

\begin{tabular}{|c|c|c|c|c|c|c|c|}
\hline \multirow[t]{2}{*}{ Study or subgroup } & \multicolumn{2}{|c|}{ NO donor } & \multicolumn{2}{|c|}{ Control } & \multirow{2}{*}{$\begin{array}{l}\text { Mean Difference } \\
\text { Random, } 95 \% \mathrm{Cl}\end{array}$} & \multirow[t]{2}{*}{ Weight } & \multirow{2}{*}{$\begin{array}{l}\text { Mean Difference } \\
\text { Random, } 95 \% \mathrm{Cl}\end{array}$} \\
\hline & $\mathbf{N}$ & Mean(SD) & $\mathbf{N}$ & $\operatorname{Mean}(S D)$ & & & \\
\hline \multicolumn{8}{|l|}{ 1.45.1 Overall } \\
\hline ENOS 2015 & 995 & $14.9(10.5)$ & 1018 & $14.6(10.8)$ & - & $100 \%$ & $0.3[-0.63,1.23]$ \\
\hline Subtotal $\star \star \star \star$ & 995 & & 1018 & & & $100 \%$ & $0.3[-0.63,1.23]$ \\
\hline \multicolumn{8}{|c|}{ Heterogeneity: Not applicable } \\
\hline \multicolumn{8}{|c|}{ Test for overall effect: $Z=0.63(P=0.53)$} \\
\hline 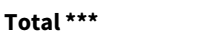 & 995 & & 1018 & & & $100 \%$ & $0.3[-0.63,1.23]$ \\
\hline \multicolumn{8}{|c|}{ Heterogeneity: Not applicable } \\
\hline Test for overall effect & & & & & & & \\
\hline
\end{tabular}

Analysis 1.46. Comparison 1 Glyceryl trinitrate (GTN) compared with no GTN for acute stroke, Outcome 46 TICS, end of trial, by stroke type.

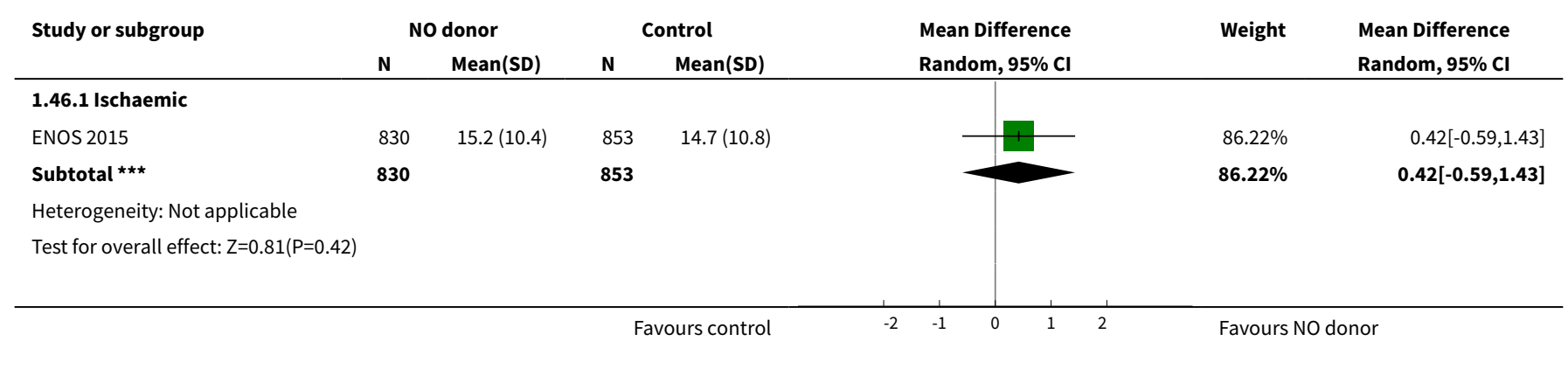




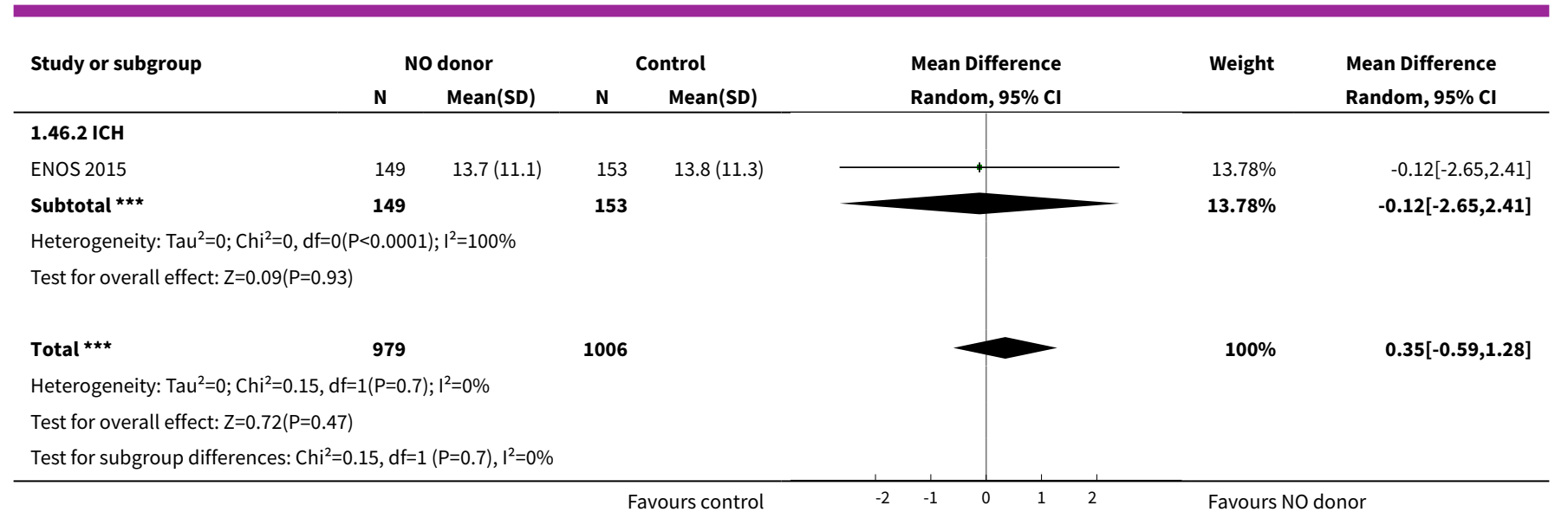

\section{Analysis 1.47. Comparison 1 Glyceryl trinitrate (GTN) compared with no GTN} for acute stroke, Outcome $47 \mathrm{TICS}$, end of trial, by time to randomisation.

\begin{tabular}{|c|c|c|c|c|c|c|c|}
\hline \multirow{3}{*}{$\begin{array}{l}\text { Study or subgroup } \\
1.47 .1<6 \text { hours }\end{array}$} & \multicolumn{2}{|c|}{ NO donor } & \multicolumn{2}{|c|}{ Control } & \multirow{2}{*}{$\begin{array}{l}\text { Mean Difference } \\
\text { Random, } 95 \% \mathrm{Cl}\end{array}$} & \multirow[t]{2}{*}{ Weight } & \multirow{2}{*}{$\begin{array}{l}\text { Mean Difference } \\
\text { Random, } 95 \% \mathrm{CI}\end{array}$} \\
\hline & \multirow[t]{2}{*}{$\mathbf{N}$} & \multirow[t]{2}{*}{ Mean(SD) } & \multirow[t]{2}{*}{$\mathbf{N}$} & \multirow[t]{2}{*}{ Mean(SD) } & & & \\
\hline & & & & & & & \\
\hline ENOS 2015 & 92 & $19(9.6)$ & 90 & $13.4(10.7)$ & $\longrightarrow$ & $16.65 \%$ & $5.59[2.63,8.55]$ \\
\hline 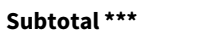 & 92 & & 90 & & & $16.65 \%$ & $5.59[2.63,8.55]$ \\
\hline \multicolumn{8}{|c|}{ Heterogeneity: $\mathrm{Tau}^{2}=0 ; \mathrm{Chi}^{2}=0, \mathrm{df}=0(\mathrm{P}<0.0001) ; \mathrm{I}^{2}=100 \%$} \\
\hline \multicolumn{8}{|c|}{ Test for overall effect: $Z=3.7(P=0)$} \\
\hline \multicolumn{8}{|c|}{ 1.47.2 6.1 to 12 hours } \\
\hline ENOS 2015 & 122 & $13.3(11.3)$ & 126 & $15.5(10.8)$ & $\longrightarrow$ & $17.57 \%$ & $-2.19[-4.94,0.56]$ \\
\hline 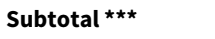 & 122 & & 126 & & & $17.57 \%$ & $-2.19[-4.94,0.56]$ \\
\hline \multicolumn{8}{|c|}{ Heterogeneity: Not applicable } \\
\hline \multicolumn{8}{|c|}{ Test for overall effect: $\mathrm{Z}=1.56(\mathrm{P}=0.12)$} \\
\hline ENOS 2015 & 275 & $14.6(10.2)$ & 274 & $15.1(10.8)$ & $\longrightarrow$ & $22.21 \%$ & $-0.56[-2.32,1.2]$ \\
\hline Subtotal $\star \star \star$ & 275 & & 274 & & & $22.21 \%$ & $-0.56[-2.32,1.2]$ \\
\hline \multicolumn{8}{|c|}{ Heterogeneity: Not applicable } \\
\hline \multicolumn{8}{|c|}{ Test for overall effect: $\mathrm{Z}=0.62(\mathrm{P}=0.53)$} \\
\hline \multicolumn{8}{|c|}{ 1.47.4 24.1 to 36 hours } \\
\hline ENOS 2015 & 290 & $14.3(10.4)$ & 293 & $14(10.7)$ & & $22.41 \%$ & $0.25[-1.46,1.96]$ \\
\hline Subtotal $* \star \star$ & 290 & & 293 & & & $22.41 \%$ & $0.25[-1.46,1.96]$ \\
\hline \multicolumn{8}{|c|}{ Heterogeneity: Not applicable } \\
\hline \multicolumn{8}{|c|}{ Test for overall effect: $Z=0.29(P=0.78)$} \\
\hline \multicolumn{8}{|l|}{$1.47 .5>36$ hours } \\
\hline ENOS 2015 & 216 & $15.3(10.4)$ & 235 & $14.6(11.1)$ & - & $21.16 \%$ & $0.66[-1.32,2.64]$ \\
\hline \multicolumn{8}{|c|}{ Heterogeneity: Not applicable } \\
\hline \multicolumn{8}{|c|}{ Test for overall effect: $Z=0.65(P=0.51)$} \\
\hline 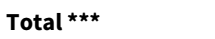 & 995 & & 1018 & & & $100 \%$ & $0.62[-1.33,2.56]$ \\
\hline \multicolumn{8}{|c|}{ Heterogeneity: Tau $^{2}=3.62 ; \mathrm{Chi}^{2}=16.43, \mathrm{df}=4(\mathrm{P}=0) ; \mathrm{I}^{2}=75.66 \%$} \\
\hline
\end{tabular}




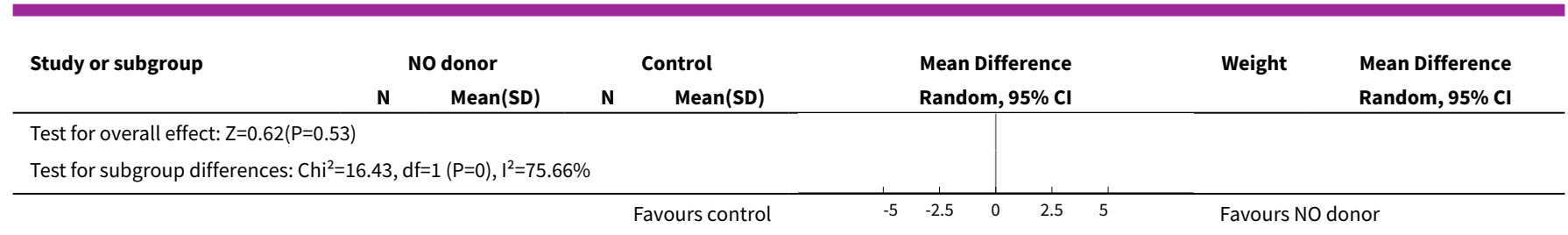

Analysis 1.48. Comparison 1 Glyceryl trinitrate (GTN) compared with no GTN for acute stroke, Outcome 48 TICS, end of trial, by baseline SBP.

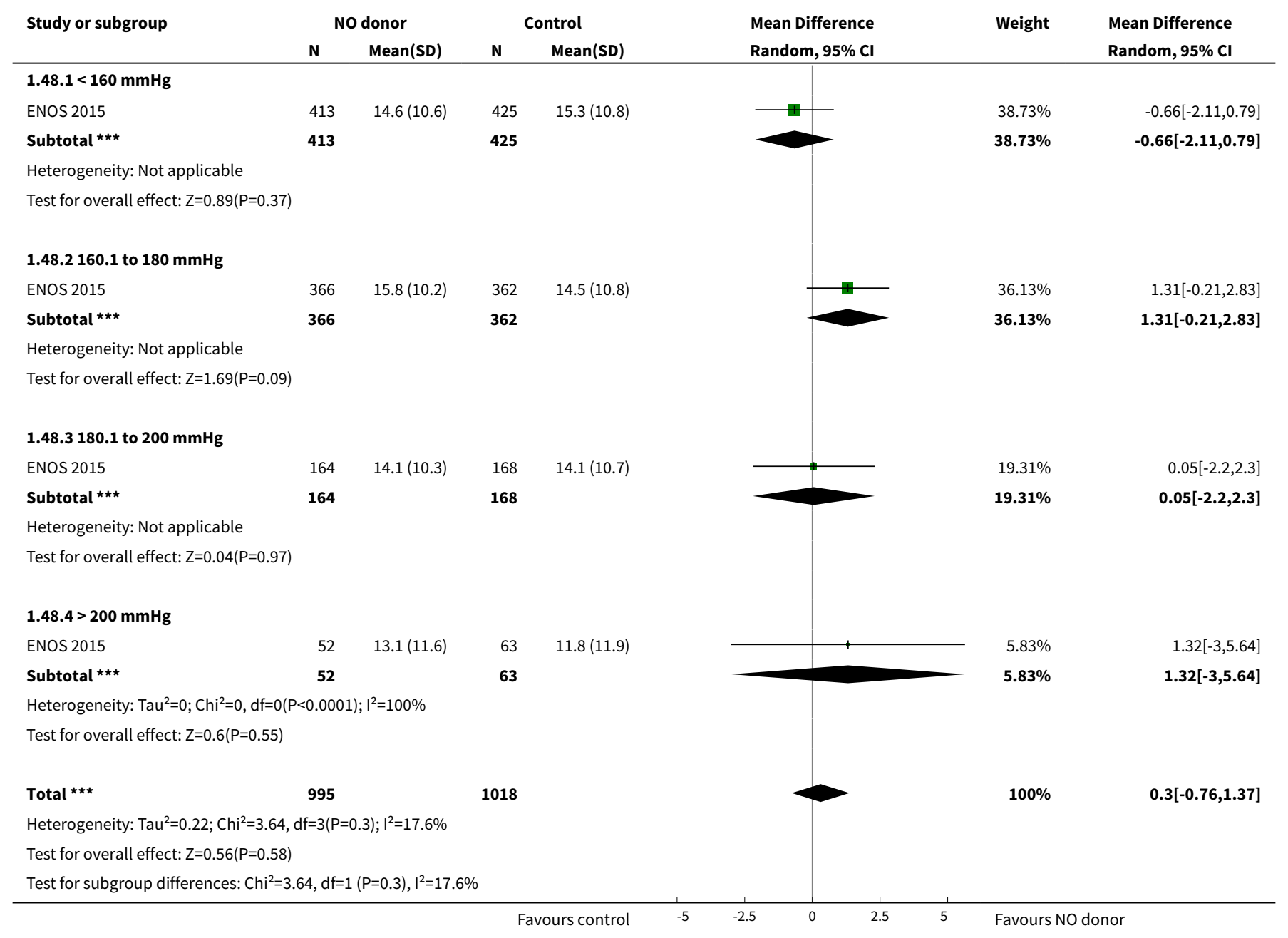

Analysis 1.49. Comparison 1 Glyceryl trinitrate (GTN) compared with no GTN for acute stroke, Outcome 49 Animal naming, end of trial.

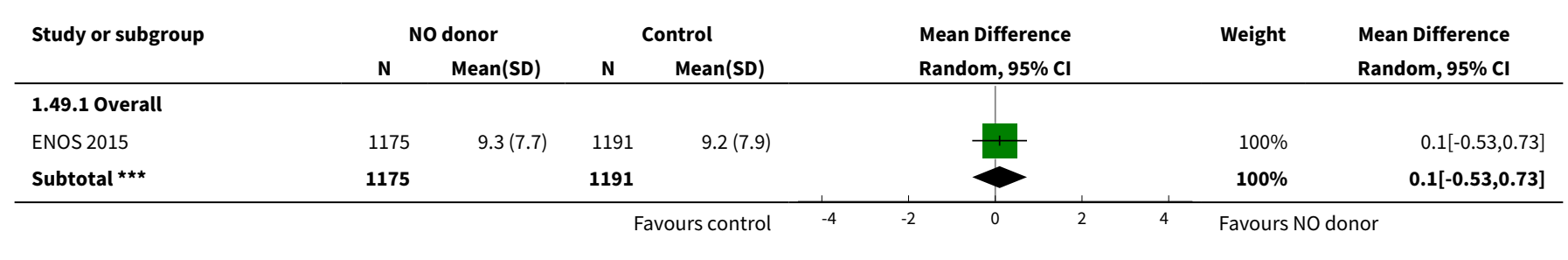




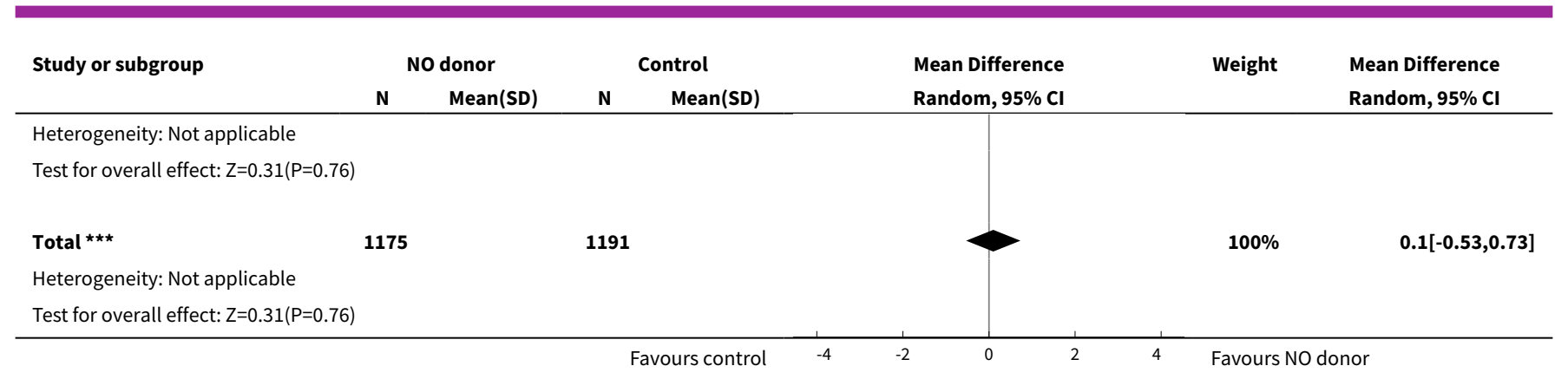

Analysis 1.50. Comparison 1 Glyceryl trinitrate (GTN) compared with no GTN for acute stroke, Outcome 50 Animal naming, end of trial, by stroke type.

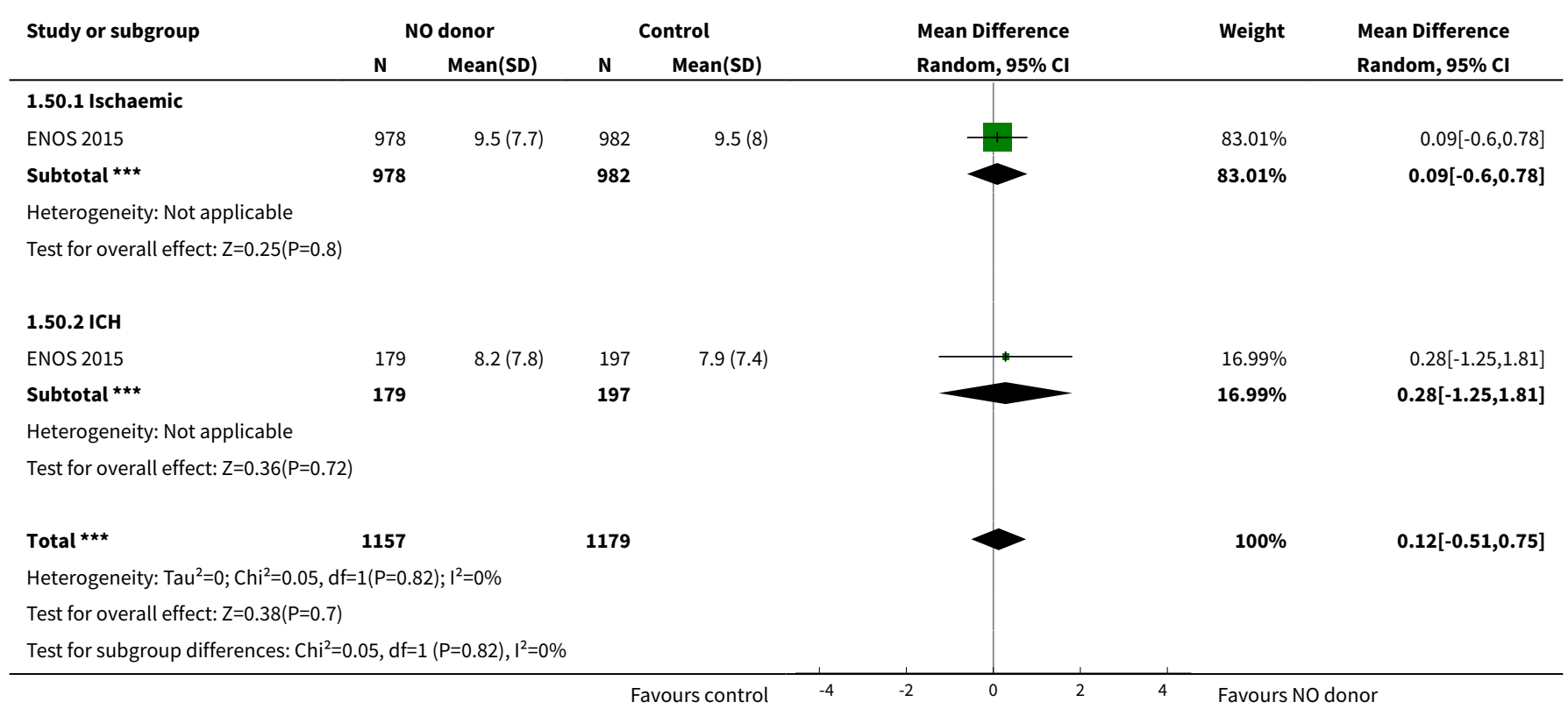

Analysis 1.51. Comparison 1 Glyceryl trinitrate (GTN) compared with no GTN for acute stroke, Outcome 51 Animal naming, end of trial, by time to randomisation.

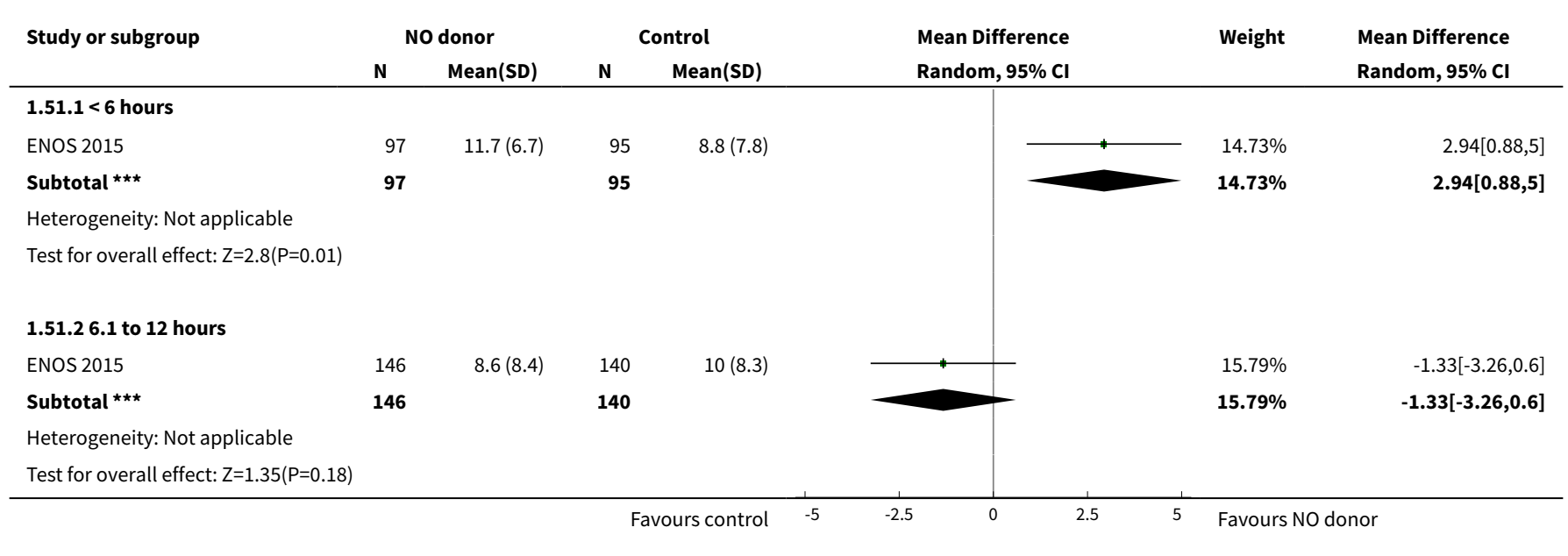




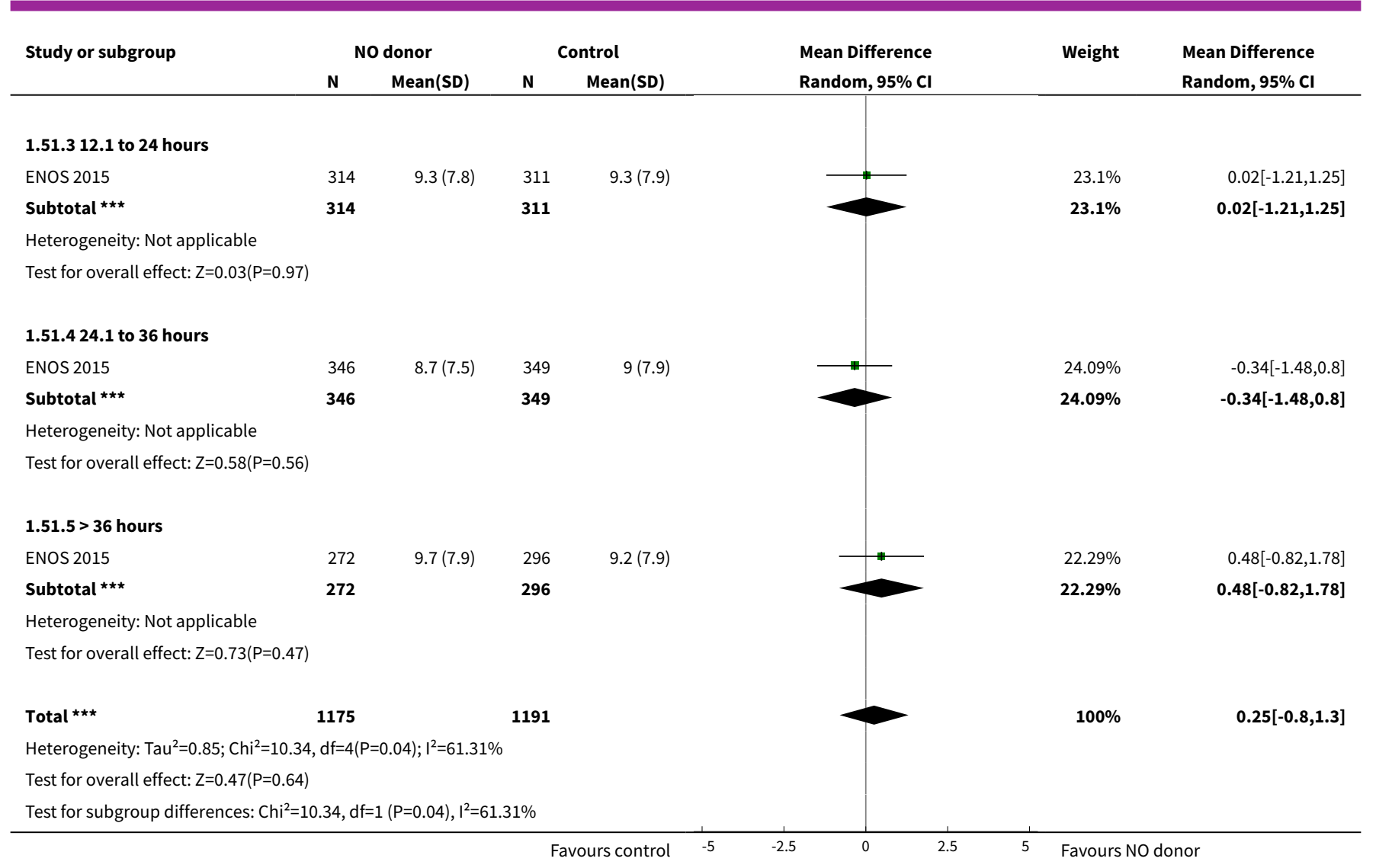

Analysis 1.52. Comparison 1 Glyceryl trinitrate (GTN) compared with no GTN for acute stroke, Outcome 52 Animal naming, end of trial, by baseline SBP.

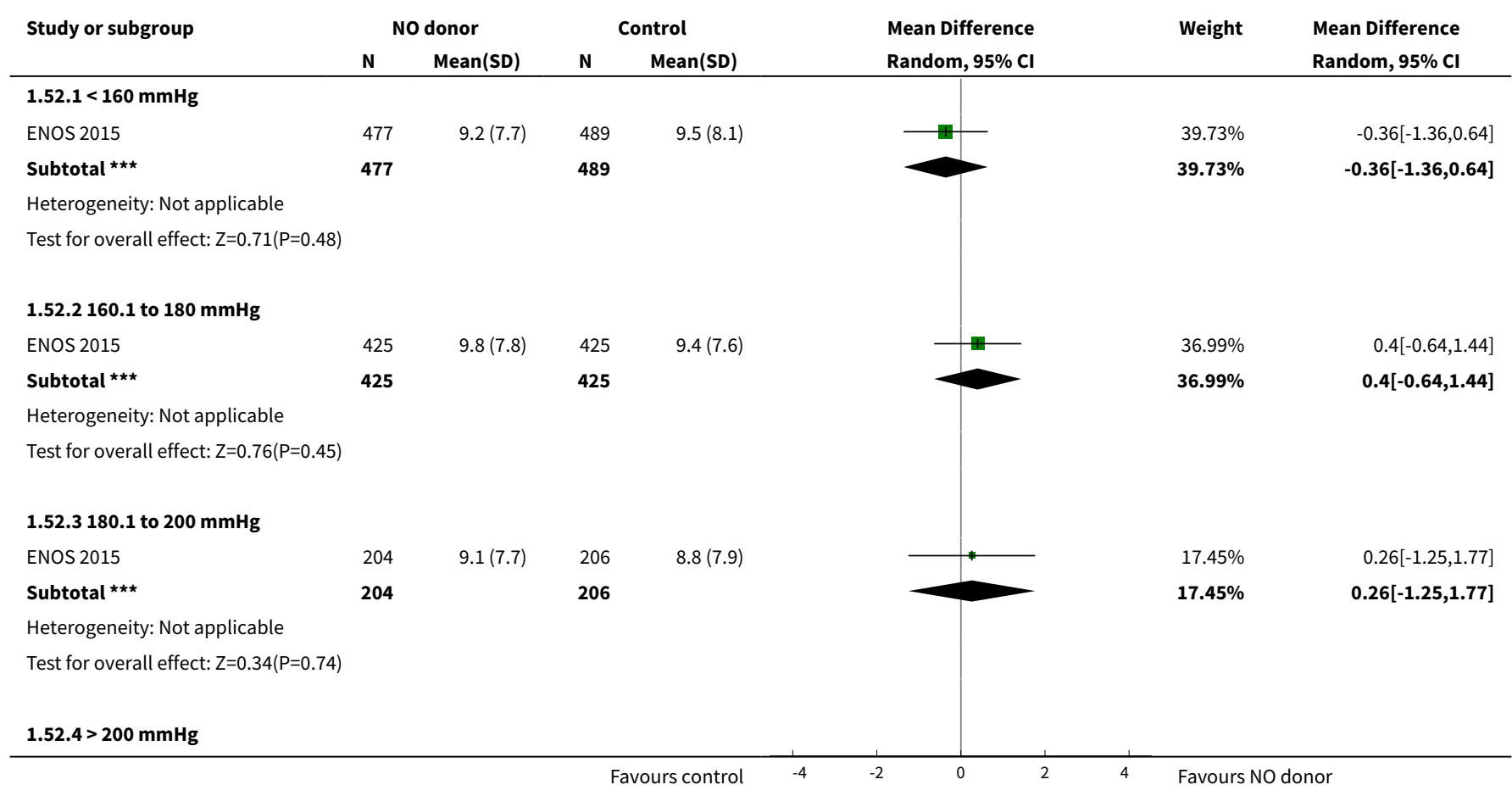




\begin{tabular}{|c|c|c|c|c|c|c|c|}
\hline \multirow{3}{*}{$\begin{array}{l}\text { Study or subgroup } \\
\text { ENOS } 2015\end{array}$} & \multicolumn{2}{|c|}{ NO donor } & \multicolumn{2}{|c|}{ Control } & \multirow{2}{*}{$\begin{array}{l}\text { Mean Difference } \\
\text { Random, } 95 \% \mathrm{Cl}\end{array}$} & \multirow[t]{2}{*}{ Weight } & \multirow{2}{*}{$\begin{array}{l}\text { Mean Difference } \\
\text { Random, } 95 \% \mathrm{Cl}\end{array}$} \\
\hline & $\mathbf{N}$ & $\operatorname{Mean}(S D)$ & $\mathbf{N}$ & Mean(SD) & & & \\
\hline & 69 & $8.1(7.5)$ & 71 & $7.2(8.3)$ & \begin{tabular}{l|l} 
& 1 \\
\end{tabular} & $5.83 \%$ & $0.92[-1.69,3.53]$ \\
\hline Subtotal $\star \star \star$ & 69 & & 71 & & & $5.83 \%$ & $0.92[-1.69,3.53]$ \\
\hline \multicolumn{8}{|c|}{ Heterogeneity: $\mathrm{Tau}^{2}=0 ; \mathrm{Chi}^{2}=0, \mathrm{df}=0(\mathrm{P}<0.0001) ; \mathrm{I}^{2}=100 \%$} \\
\hline \multicolumn{8}{|c|}{ Test for overall effect: $Z=0.69(P=0.49)$} \\
\hline 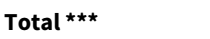 & 1175 & & 1191 & & & $100 \%$ & $0.1[-0.53,0.73]$ \\
\hline \multicolumn{8}{|c|}{ Heterogeneity: $\operatorname{Tau}^{2}=0 ; \mathrm{Chi}^{2}=1.56, \mathrm{df}=3(\mathrm{P}=0.67) ; \mathrm{I}^{2}=0 \%$} \\
\hline \multicolumn{8}{|c|}{ Test for overall effect: $\mathrm{Z}=0.32(\mathrm{P}=0.75)$} \\
\hline \multicolumn{8}{|c|}{ Test for subgroup differences: $\mathrm{Chi}^{2}=1.56, \mathrm{df}=1(\mathrm{P}=0.67), \mathrm{I}^{2}=0 \%$} \\
\hline & & & & urs control & -2 & Favours I & nor \\
\hline
\end{tabular}

\section{Analysis 1.53. Comparison 1 Glyceryl trinitrate (GTN) compared with no GTN for acute stroke, Outcome 53 Physiotherapy.}

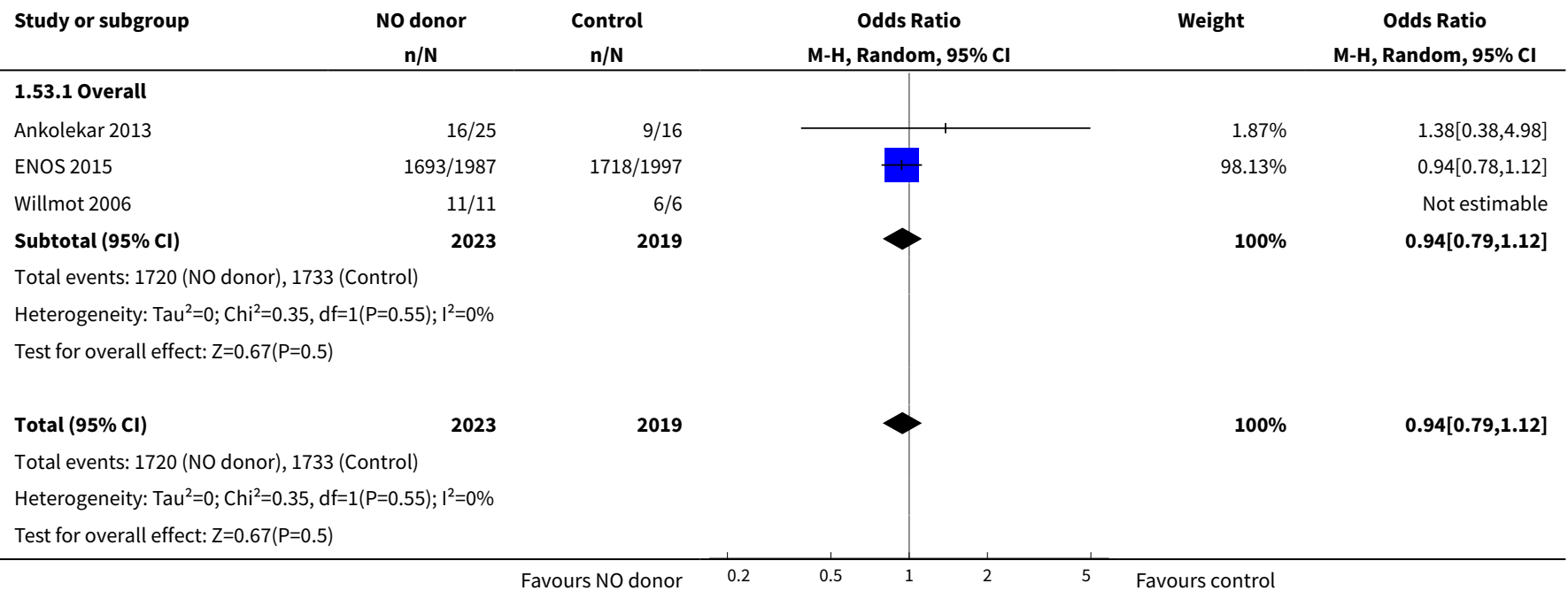

Analysis 1.54. Comparison 1 Glyceryl trinitrate (GTN) compared with no GTN for acute stroke, Outcome 54 Physiotherapy, by stroke type.

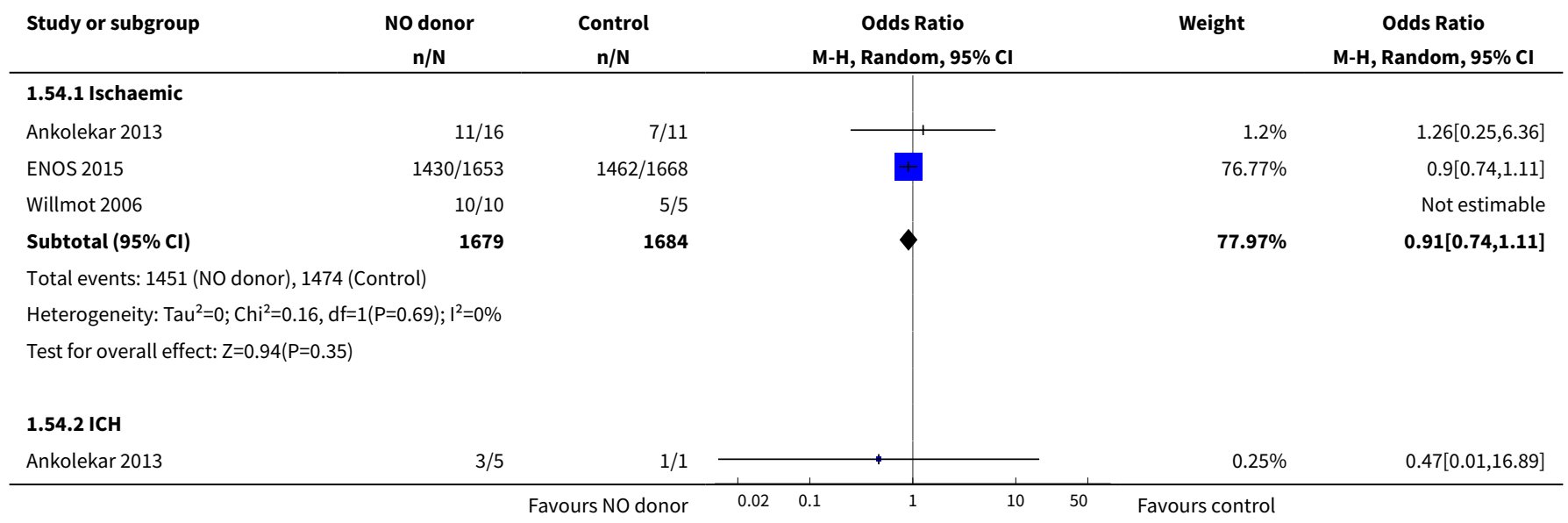




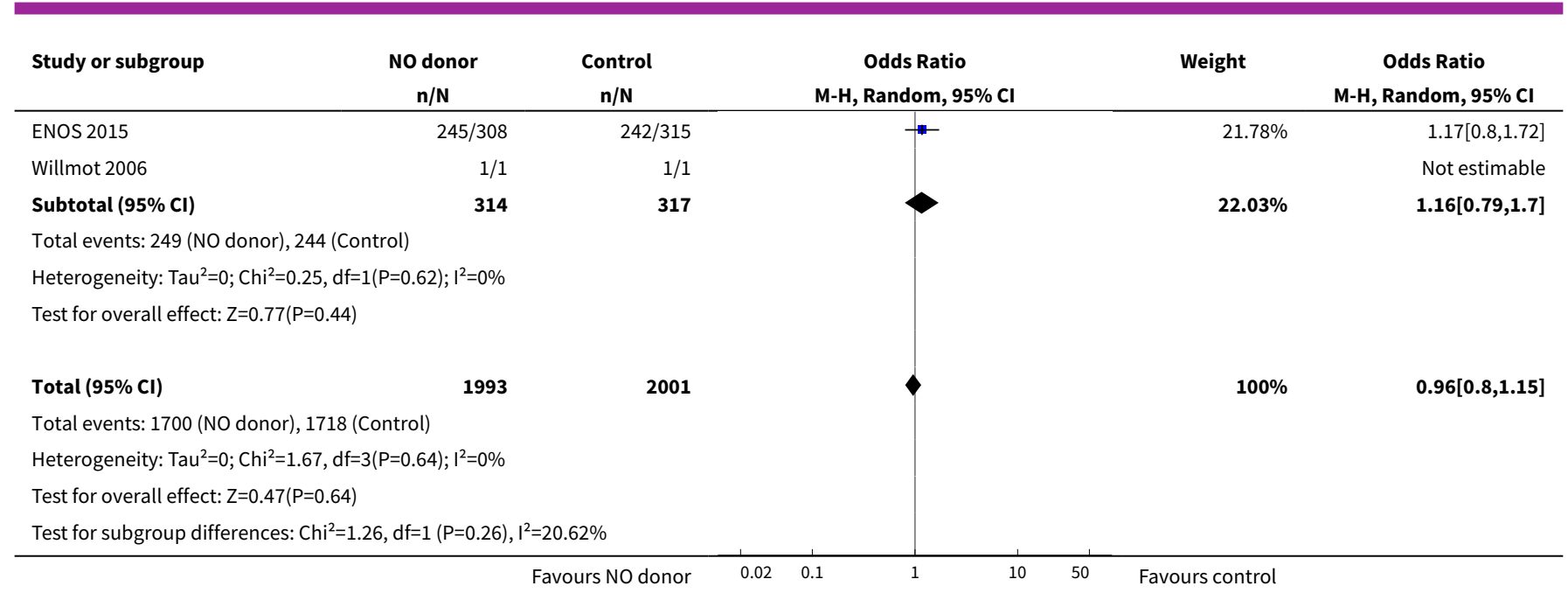

Analysis 1.55. Comparison 1 Glyceryl trinitrate (GTN) compared with no GTN for acute stroke, Outcome 55 Physiotherapy, by time to randomisation.

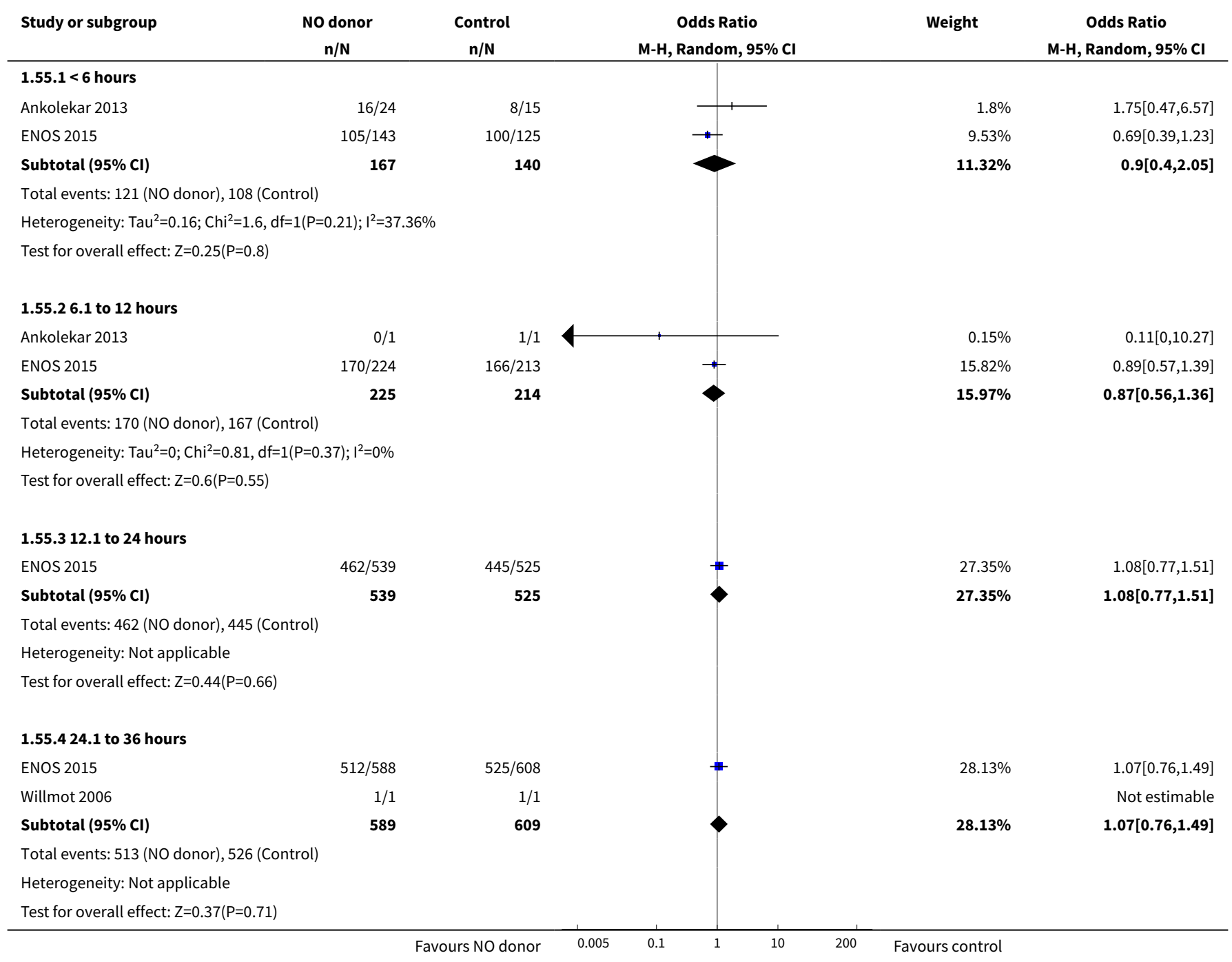




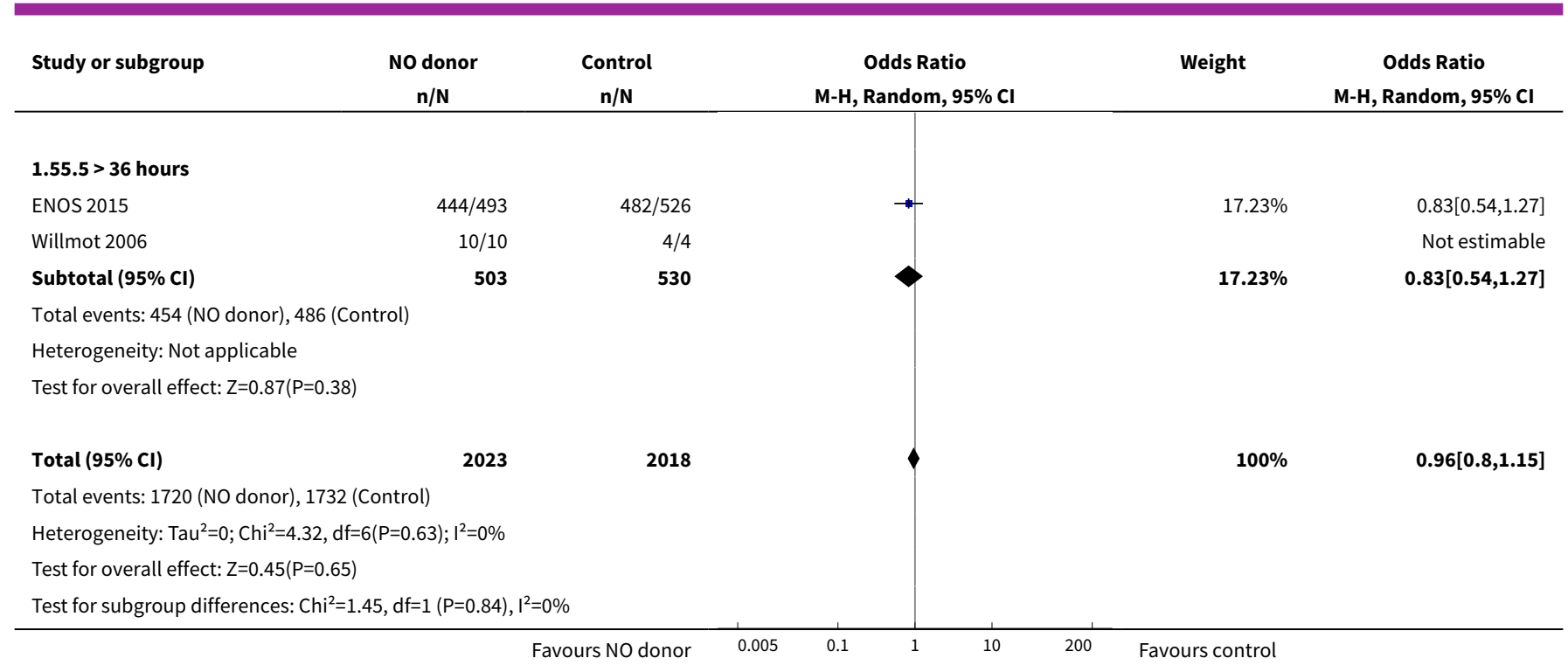

\section{Analysis 1.56. Comparison $1 \mathrm{Glyceryl}$ trinitrate (GTN) compared with no GTN for acute stroke, Outcome 56 Physiotherapy, by baseline SBP.}

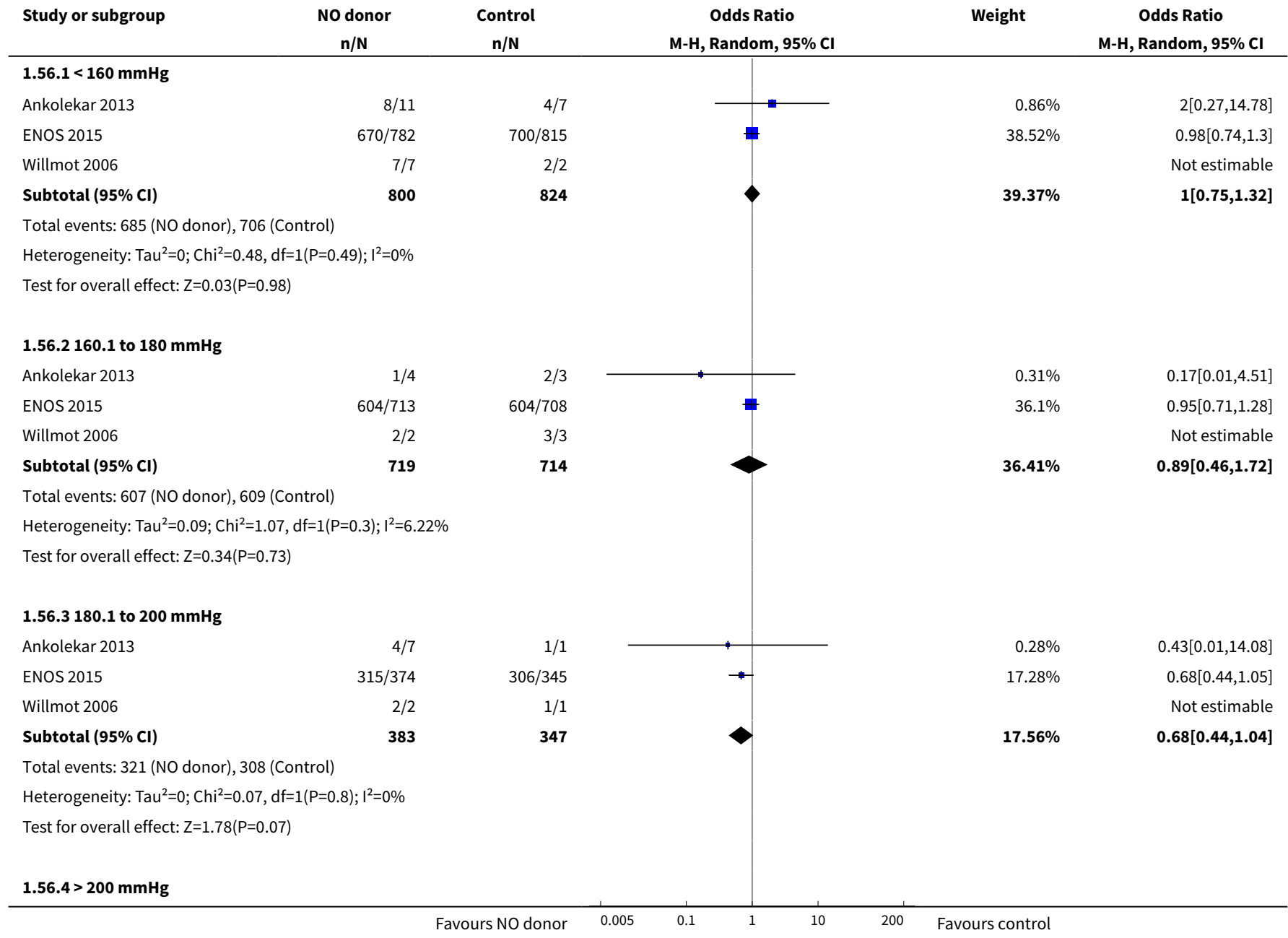




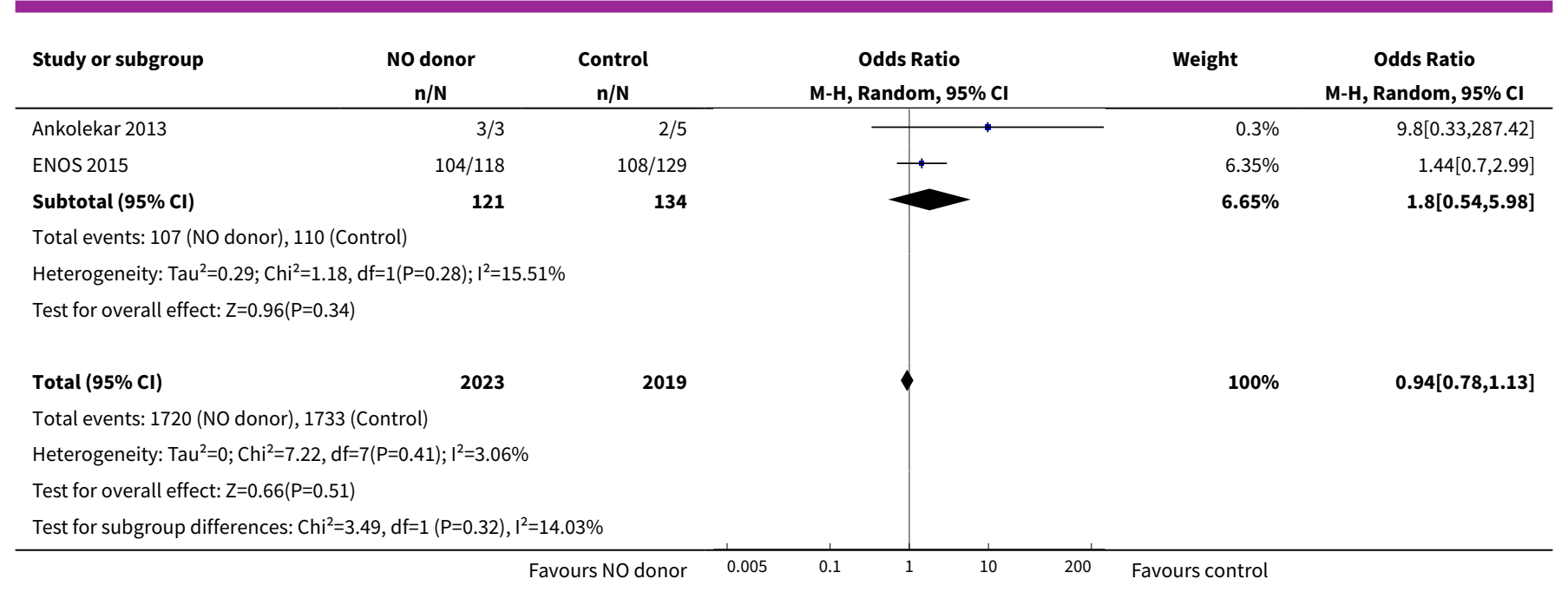

Analysis 1.57. Comparison 1 Glyceryl trinitrate (GTN) compared with no GTN for acute stroke, Outcome 57 Occupational therapy.

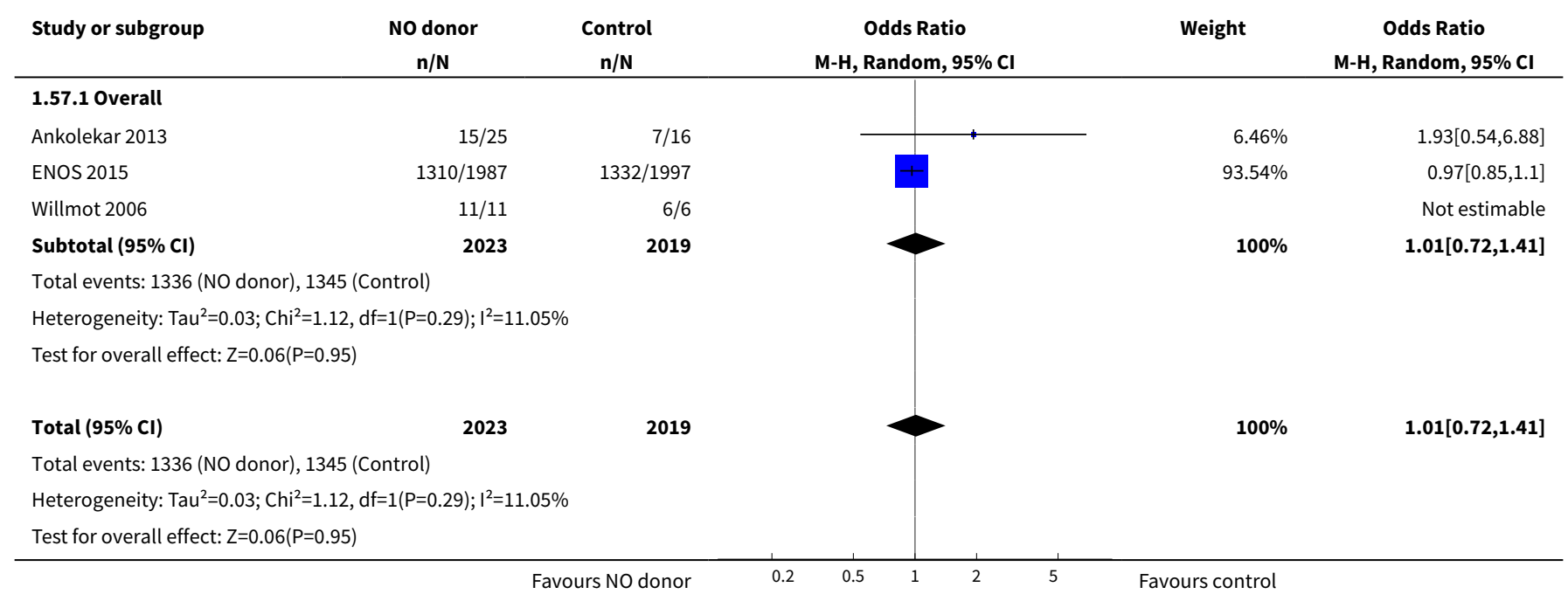

Analysis 1.58. Comparison 1 Glyceryl trinitrate (GTN) compared with no GTN for acute stroke, Outcome 58 Occupational therapy, by stroke type.

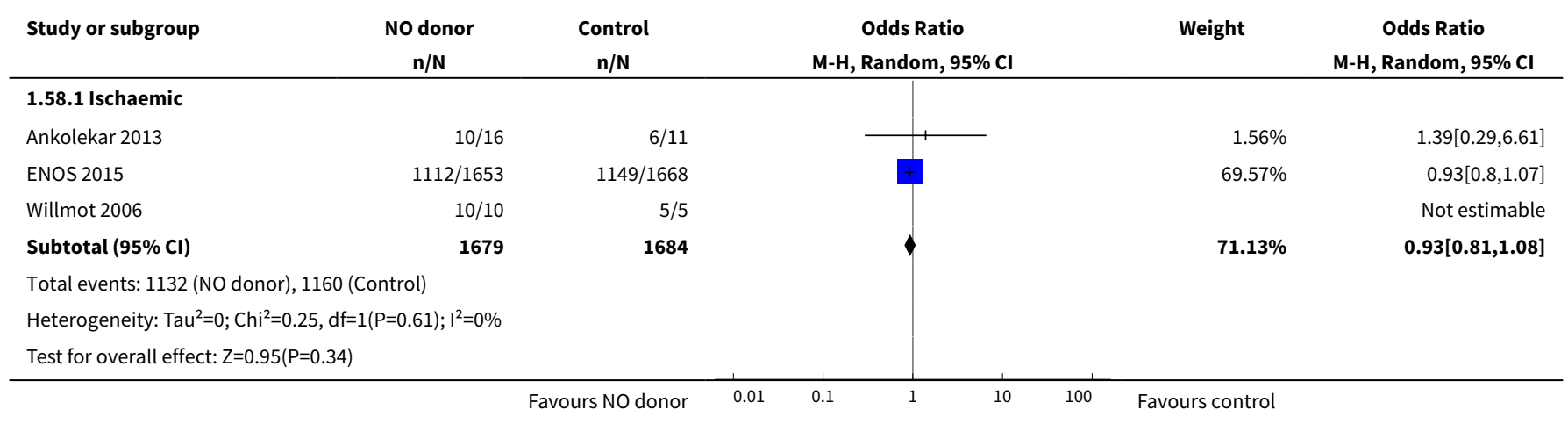




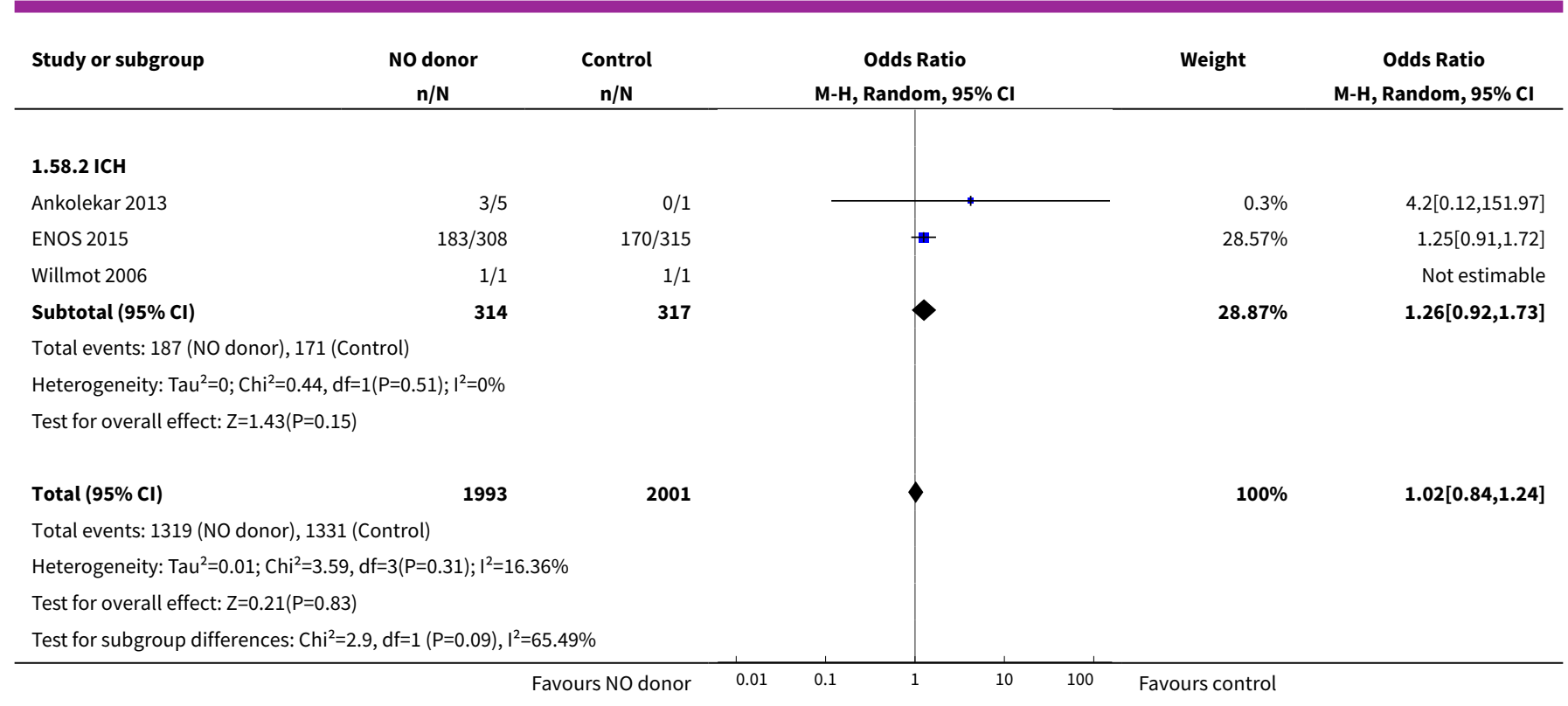

Analysis 1.59. Comparison 1 Glyceryl trinitrate (GTN) compared with no GTN for acute stroke, Outcome 59 Occupational therapy, by time to randomisation.

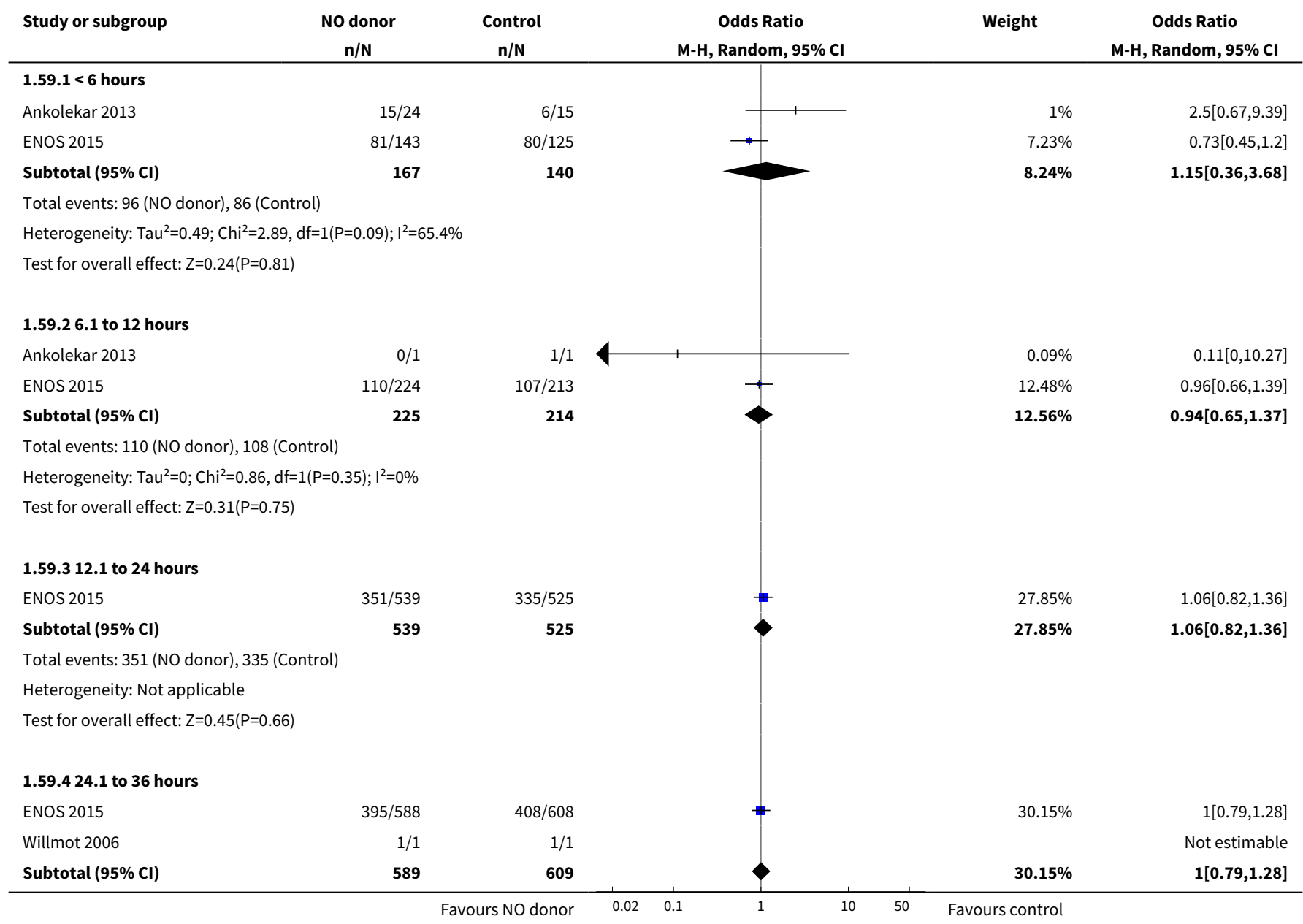




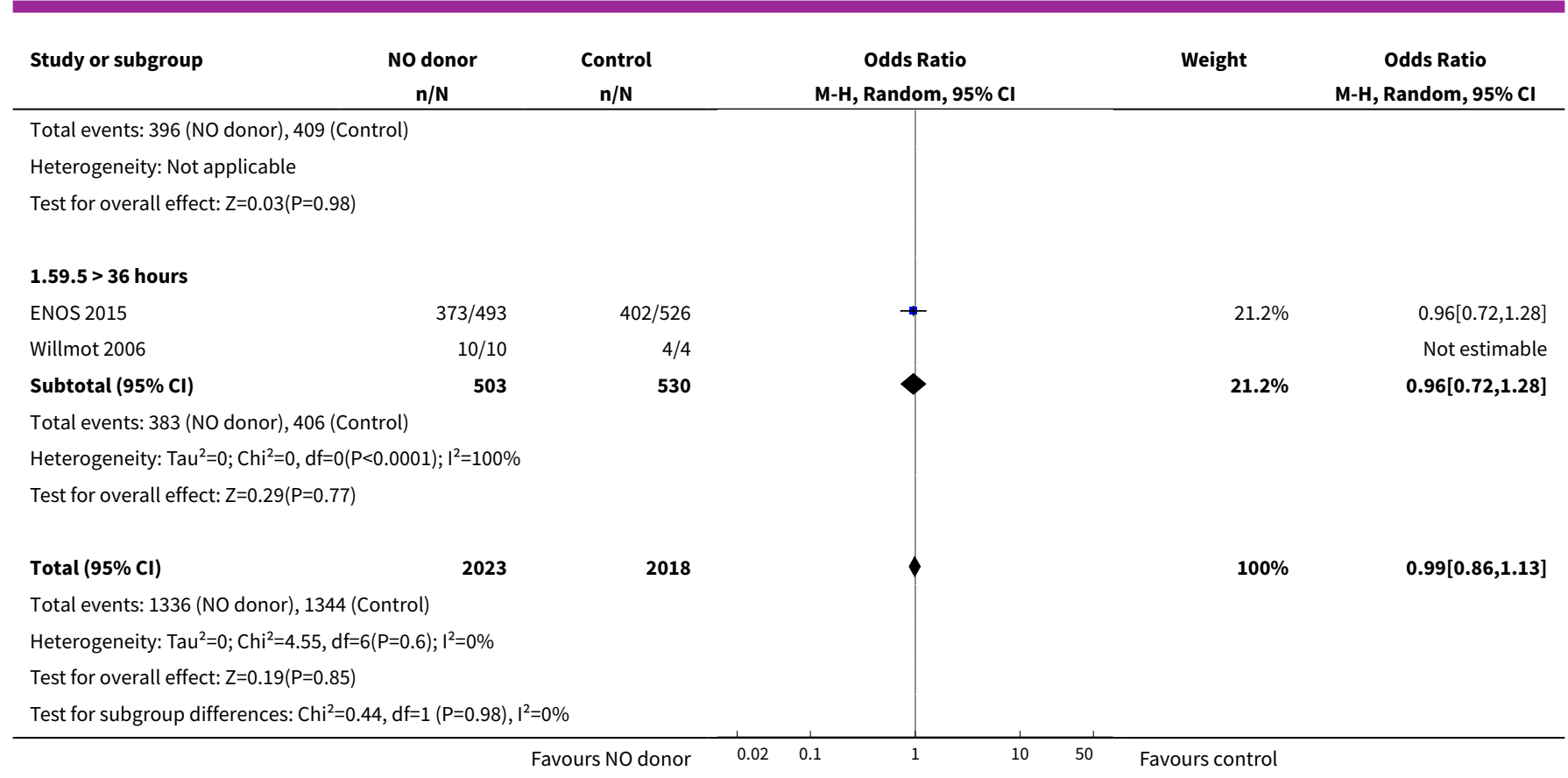
Analysis 1.60. Comparison 1 Glyceryl trinitrate (GTN) compared with no
GTN for acute stroke, Outcome 60 Occupational therapy, by baseline SBP.

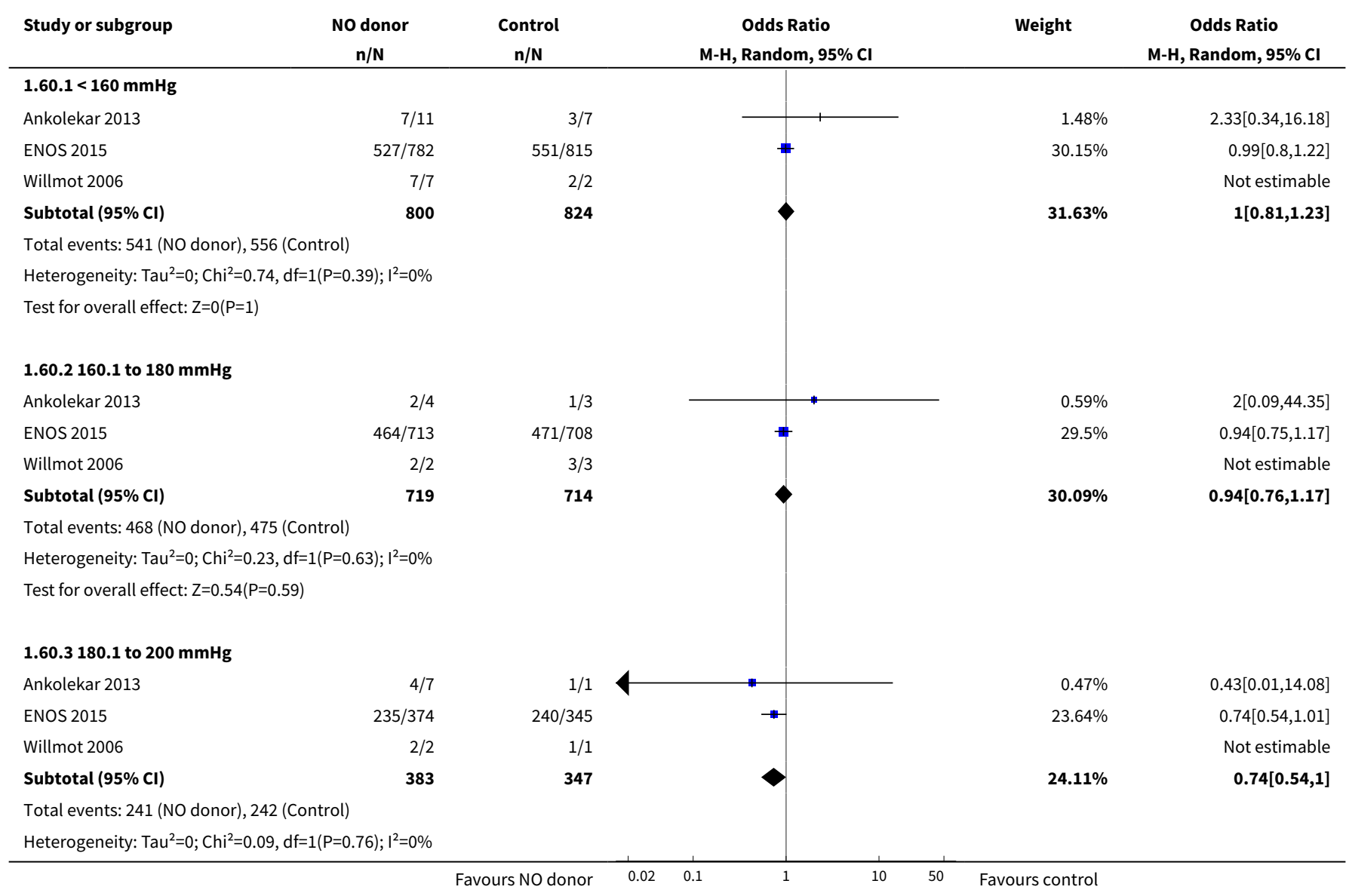




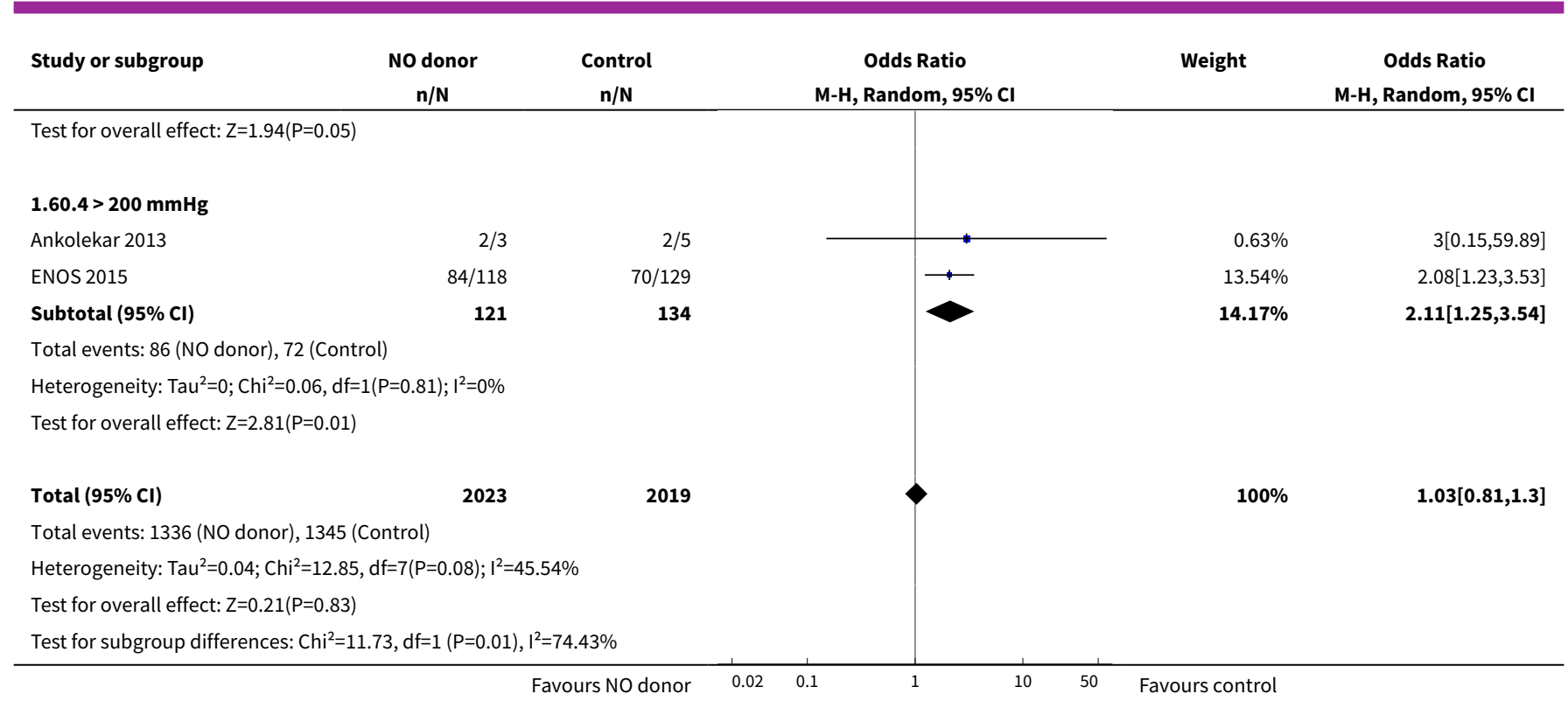

Analysis 1.61. Comparison 1 Glyceryl trinitrate (GTN) compared with no GTN for acute stroke, Outcome 61 Speech and language therapy.

\begin{tabular}{|c|c|c|c|c|c|}
\hline Study or subgroup & $\begin{array}{c}\text { NO donor } \\
\mathrm{n} / \mathrm{N}\end{array}$ & $\begin{array}{c}\text { Control } \\
n / N\end{array}$ & $\begin{array}{c}\text { Odds Ratio } \\
\text { M-H, Random, } 95 \% \mathrm{Cl}\end{array}$ & Weight & $\begin{array}{c}\text { Odds Ratio } \\
\text { M-H, Random, } 95 \% \mathrm{Cl}\end{array}$ \\
\hline \multicolumn{6}{|l|}{ 1.61.1 Overall } \\
\hline Ankolekar 2013 & $12 / 25$ & $6 / 16$ & $\longrightarrow$ & $0.93 \%$ & $1.54[0.43,5.54]$ \\
\hline ENOS 2015 & $974 / 1987$ & $1005 / 1997$ & & $98.78 \%$ & $0.95[0.84,1.07]$ \\
\hline Willmot 2006 & $2 / 11$ & $2 / 6$ & & $0.29 \%$ & $0.44[0.05,4.37]$ \\
\hline Subtotal $(95 \% \mathrm{CI})$ & 2023 & 2019 & 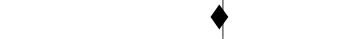 & $100 \%$ & $0.95[0.84,1.08]$ \\
\hline \multicolumn{6}{|c|}{ Heterogeneity: $\operatorname{Tau}^{2}=0 ; \mathrm{Chi}^{2}=0.97, \mathrm{df}=2(\mathrm{P}=0.62) ; \mathrm{I}^{2}=0 \%$} \\
\hline \multicolumn{6}{|c|}{ Test for overall effect: $Z=0.79(P=0.43)$} \\
\hline Total $(95 \% \mathrm{Cl})$ & 2023 & 2019 & $\gamma$ & $100 \%$ & $0.95[0.84,1.08]$ \\
\hline \multicolumn{6}{|c|}{ Total events: 988 (NO donor), 1013 (Control) } \\
\hline \multicolumn{6}{|c|}{ Heterogeneity: $\operatorname{Tau}^{2}=0 ; \mathrm{Chi}^{2}=0.97, \mathrm{df}=2(\mathrm{P}=0.62) ; \mathrm{I}^{2}=0 \%$} \\
\hline
\end{tabular}

Analysis 1.62. Comparison 1 Glyceryl trinitrate (GTN) compared with no GTN for acute stroke, Outcome 62 Speech and language therapy, by stroke type.

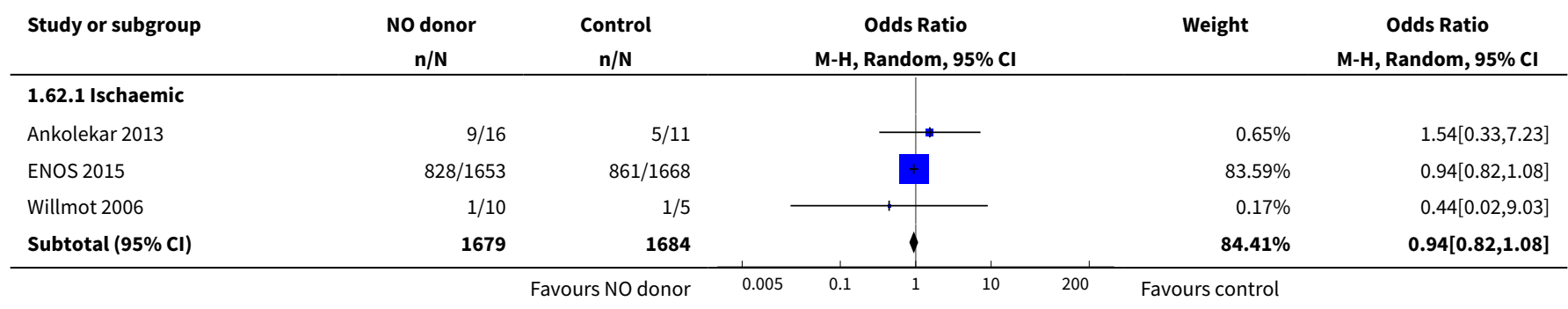




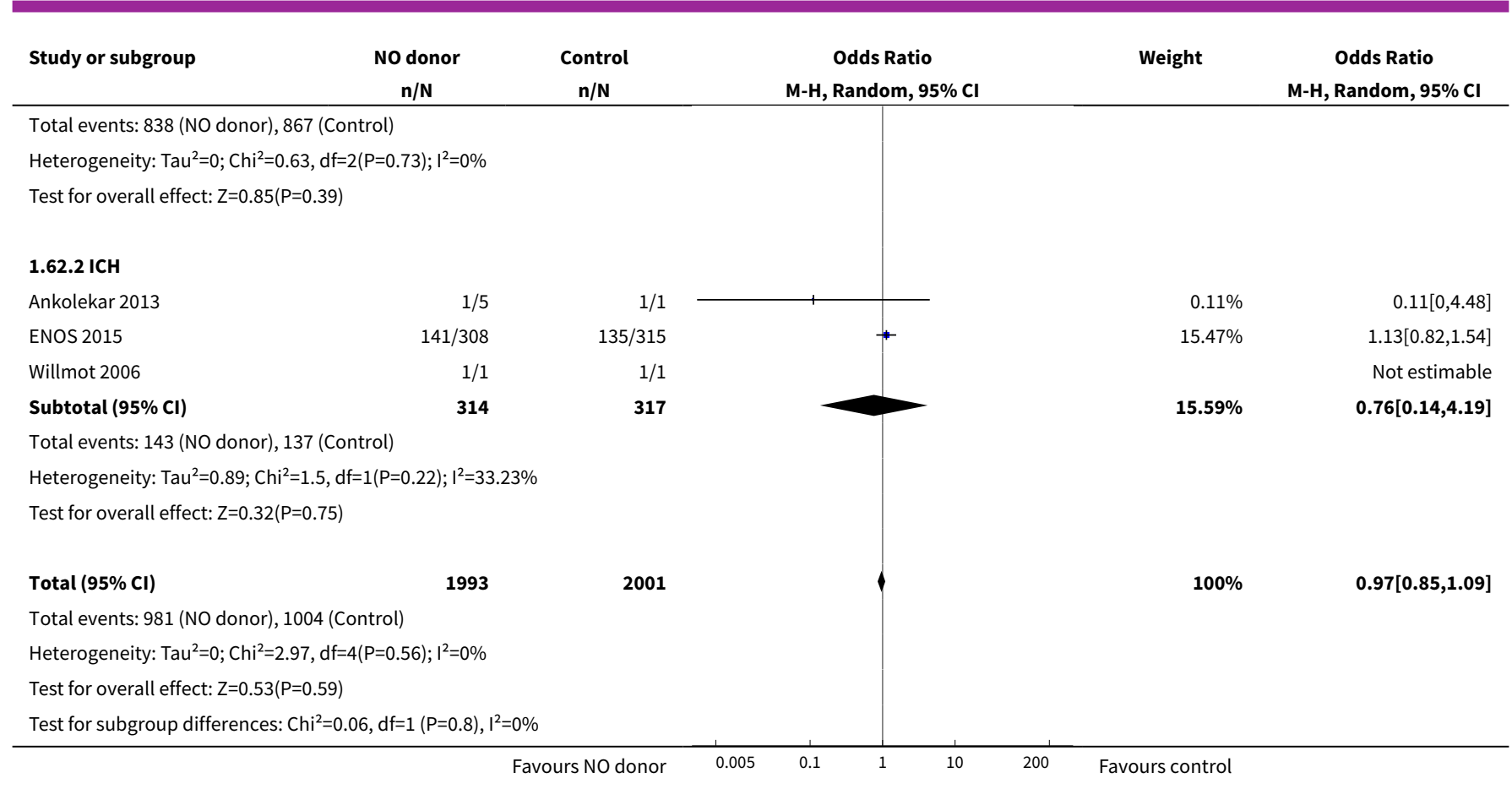

Analysis 1.63. Comparison 1 Glyceryl trinitrate (GTN) compared with no GTN for
acute stroke, Outcome 63 Speech and language therapy, by time to randomisation.

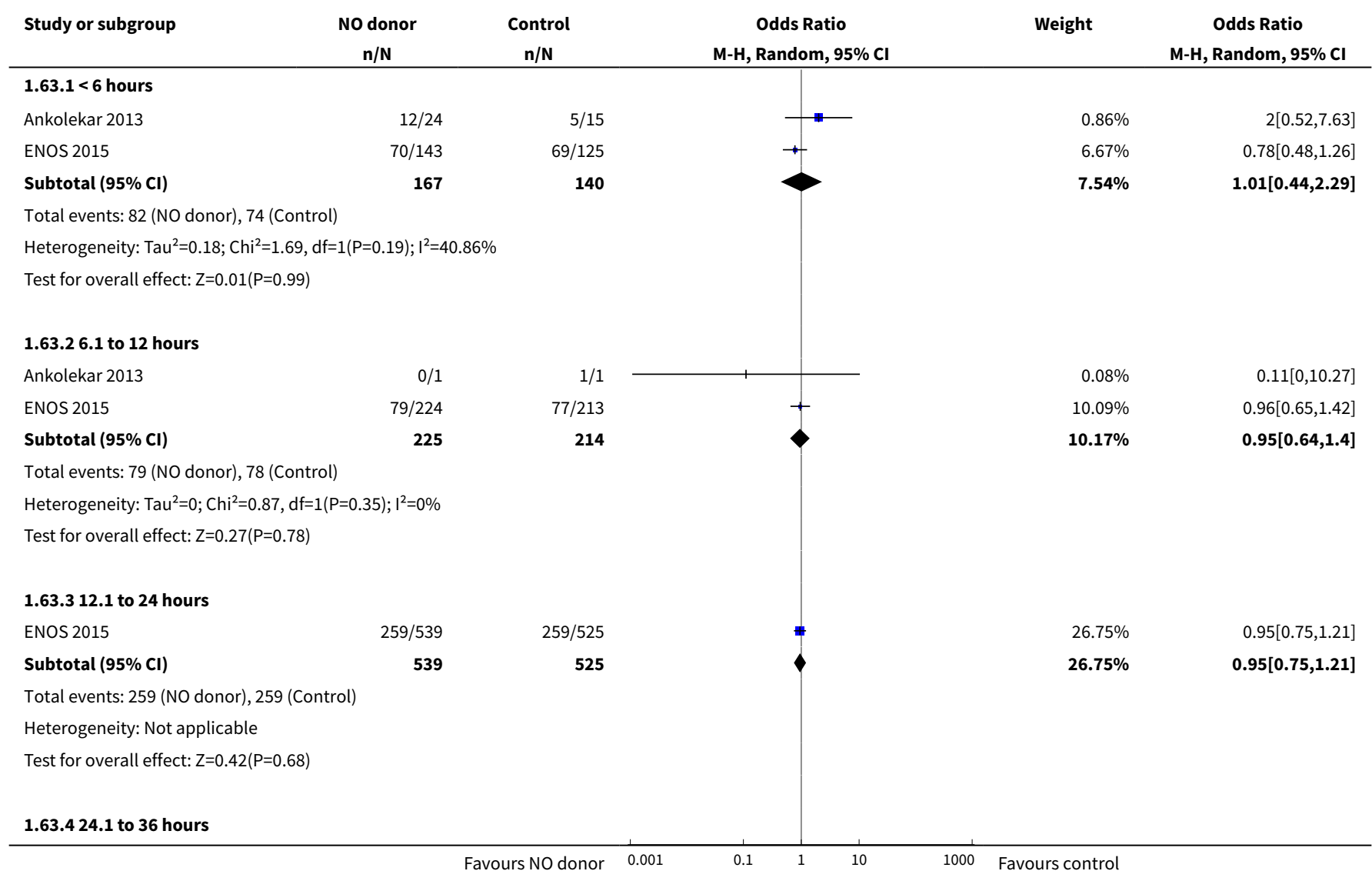




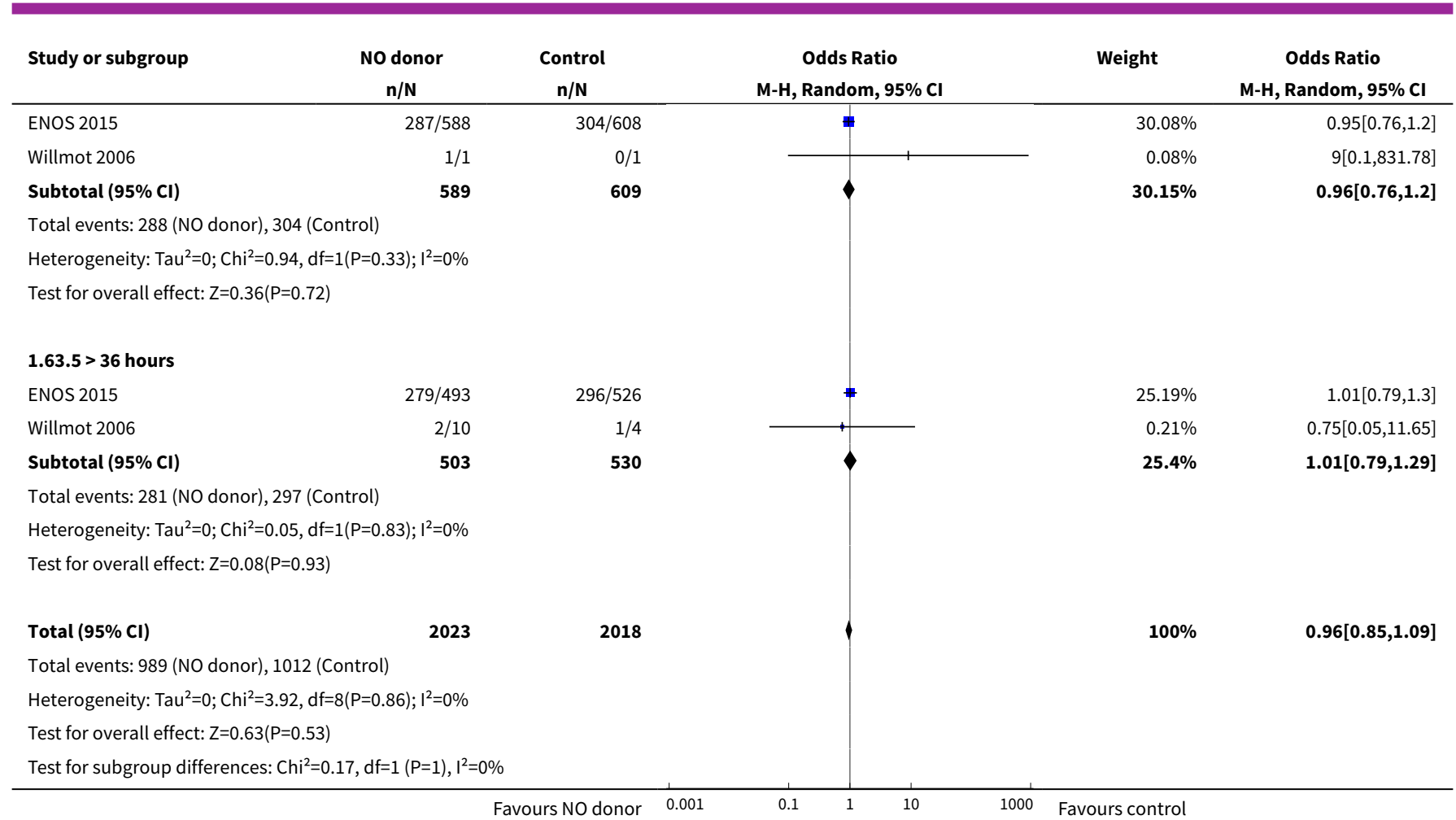

Analysis 1.64. Comparison 1 Glyceryl trinitrate (GTN) compared with no GTN for acute stroke, Outcome 64 Speech and language therapy, by baseline SBP.

\begin{tabular}{|c|c|c|c|c|c|}
\hline Study or subgroup & $\begin{array}{c}\text { NO donor } \\
n / N\end{array}$ & $\begin{array}{c}\text { Control } \\
\mathrm{n} / \mathrm{N}\end{array}$ & $\begin{array}{c}\text { Odds Ratio } \\
\text { M-H, Random, } 95 \% \mathrm{Cl}\end{array}$ & Weight & $\begin{array}{c}\text { Odds Ratio } \\
\text { M-H, Random, } 95 \% \mathrm{CI}\end{array}$ \\
\hline \multicolumn{6}{|l|}{$1.64 .1<160 \mathrm{mmHg}$} \\
\hline Ankolekar 2013 & $8 / 11$ & $3 / 7$ & $\longrightarrow$ & $0.38 \%$ & $3.56[0.48,26.28]$ \\
\hline ENOS 2015 & $379 / 782$ & $423 / 815$ & H & $39.65 \%$ & $0.87[0.72,1.06]$ \\
\hline Willmot 2006 & $2 / 7$ & $0 / 2$ & & $0.13 \%$ & $2.27[0.08,67.05]$ \\
\hline Subtotal $(95 \% \mathrm{CI})$ & 800 & 824 & & $40.17 \%$ & $0.98[0.58,1.66]$ \\
\hline \multicolumn{6}{|c|}{ Heterogeneity: $\mathrm{Tau}^{2}=0.07 ; \mathrm{Chi}^{2}=2.18, \mathrm{df}=2(\mathrm{P}=0.34) ; \mathrm{I}^{2}=8.19 \%$} \\
\hline \multicolumn{6}{|c|}{ Test for overall effect: $Z=0.09(P=0.93)$} \\
\hline \multicolumn{6}{|c|}{1.64 .2160 .1 to $180 \mathrm{mmHg}$} \\
\hline Ankolekar 2013 & $0 / 4$ & $1 / 3$ & & $0.12 \%$ & $0.19[0.01,6.48]$ \\
\hline ENOS 2015 & $344 / 713$ & $351 / 708$ & $=$ & $35.32 \%$ & $0.95[0.77,1.17]$ \\
\hline Subtotal $(95 \% \mathrm{Cl})$ & 719 & 714 & \rangle & $35.55 \%$ & $0.94[0.76,1.16]$ \\
\hline \multicolumn{6}{|c|}{ Total events: 344 (NO donor), 353 (Control) } \\
\hline \multicolumn{6}{|c|}{ Heterogeneity: $\operatorname{Tau}^{2}=0 ; \mathrm{Chi}^{2}=1.12, \mathrm{df}=2(\mathrm{P}=0.57) ; \mathrm{I}^{2}=0 \%$} \\
\hline \multicolumn{6}{|c|}{ Test for overall effect: $Z=0.59(P=0.56)$} \\
\hline \multicolumn{6}{|c|}{ 1.64.3 180.1 to $200 \mathrm{mmHg}$} \\
\hline Ankolekar 2013 & $2 / 7$ & $0 / 1$ & & $0.12 \%$ & $1.36[0.04,46.65]$ \\
\hline ENOS 2015 & $192 / 374$ & $176 / 345$ & $\rightarrow$ & $17.84 \%$ & $1.01[0.76,1.36]$ \\
\hline Willmot 2006 & $0 / 2$ & $1 / 1$ & & $0.08 \%$ & $0.07[0,5.49]$ \\
\hline
\end{tabular}




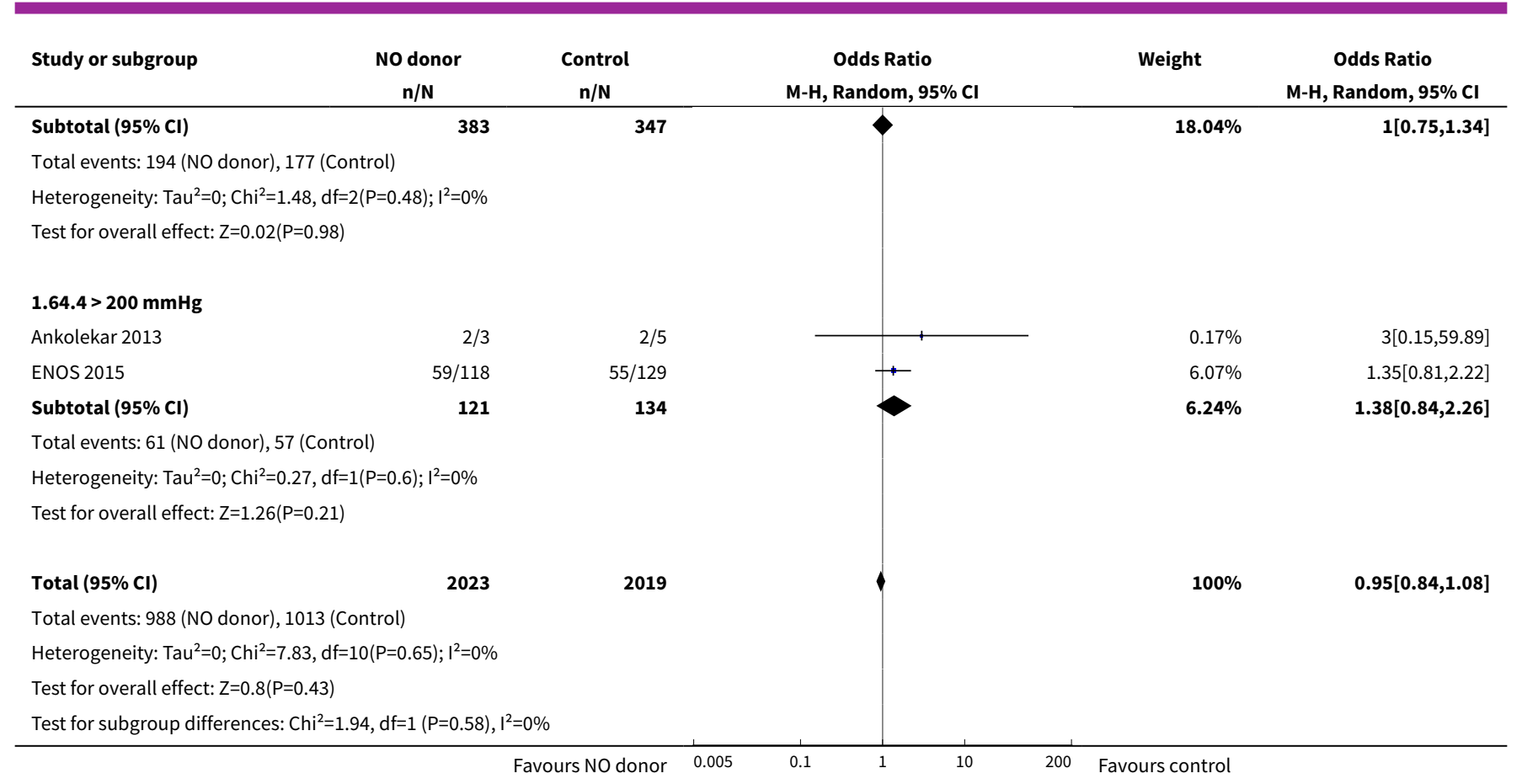

Analysis 1.65. Comparison 1 Glyceryl trinitrate (GTN) compared with no GTN for acute stroke, Outcome 65 Feeding route (non-oral feeding at day 7 ).

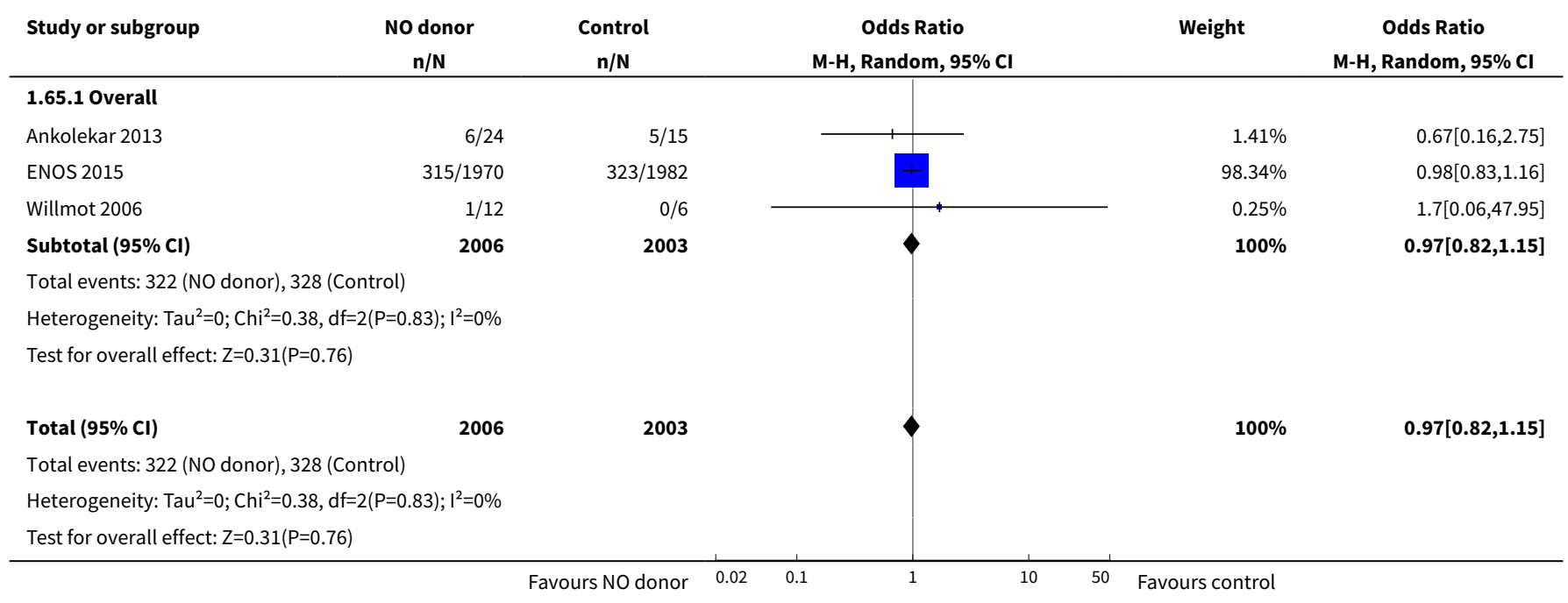

Analysis 1.66. Comparison 1 Glyceryl trinitrate (GTN) compared with no GTN for acute stroke, Outcome 66 Feeding route (non-oral feeding at day 7 ), by stroke type.

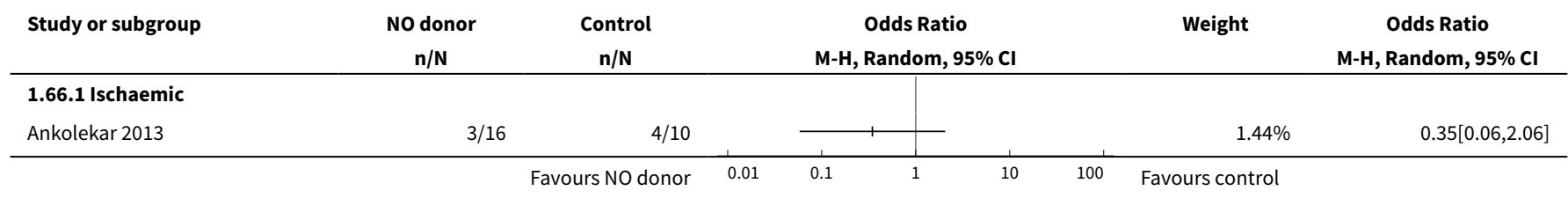




\begin{tabular}{|c|c|c|c|c|c|}
\hline Study or subgroup & $\begin{array}{c}\text { NO donor } \\
n / N\end{array}$ & $\begin{array}{c}\text { Control } \\
\mathrm{n} / \mathrm{N}\end{array}$ & $\begin{array}{c}\text { Odds Ratio } \\
\text { M-H, Random, } 95 \% \mathrm{Cl}\end{array}$ & Weight & $\begin{array}{c}\text { Odds Ratio } \\
\text { M-H, Random, } 95 \% \mathrm{Cl}\end{array}$ \\
\hline ENOS 2015 & $239 / 1640$ & $261 / 1657$ & & $71.23 \%$ & $0.91[0.75,1.1]$ \\
\hline Willmot 2006 & $1 / 11$ & $0 / 5$ & & $0.41 \%$ & $1.57[0.05,45.37]$ \\
\hline Subtotal $(95 \% \mathrm{Cl})$ & 1667 & 1672 & $\checkmark$ & $73.07 \%$ & $0.9[0.75,1.09]$ \\
\hline \multicolumn{6}{|c|}{ Total events: 243 (NO donor), 265 (Control) } \\
\hline \multicolumn{6}{|c|}{ Heterogeneity: $\operatorname{Tau}^{2}=0 ; \mathrm{Chi}^{2}=1.23, \mathrm{df}=2(\mathrm{P}=0.54) ; \mathrm{I}^{2}=0 \%$} \\
\hline \multicolumn{6}{|c|}{ Test for overall effect: $Z=1.04(P=0.3)$} \\
\hline \multicolumn{6}{|l|}{ 1.66.2 ICH } \\
\hline Ankolekar 2013 & $2 / 4$ & $1 / 1$ & & $0.35 \%$ & $0.33[0.01,12.82]$ \\
\hline ENOS 2015 & $75 / 307$ & $62 / 311$ & \pm & $26.58 \%$ & $1.3[0.89,1.9]$ \\
\hline Subtotal $(95 \% \mathrm{Cl})$ & 311 & 312 & & $26.93 \%$ & $1.28[0.88,1.87]$ \\
\hline \multicolumn{6}{|c|}{ Total events: 77 (NO donor), 63 (Control) } \\
\hline \multicolumn{6}{|c|}{ Heterogeneity: $\mathrm{Tau}^{2}=0 ; \mathrm{Chi}^{2}=0.53, \mathrm{df}=1(\mathrm{P}=0.47) ; \mathrm{I}^{2}=0 \%$} \\
\hline \multicolumn{6}{|c|}{ Test for overall effect: $Z=1.27(P=0.2)$} \\
\hline Total $(95 \% \mathrm{Cl})$ & 1978 & 1984 & $\gamma$ & $100 \%$ & $0.99[0.8,1.22]$ \\
\hline \multicolumn{6}{|c|}{ Total events: 320 (NO donor), 328 (Control) } \\
\hline \multicolumn{6}{|c|}{ Heterogeneity: $\mathrm{Tau}^{2}=0.01 ; \mathrm{Chi}^{2}=4.34, \mathrm{df}=4(\mathrm{P}=0.36) ; \mathrm{I}^{2}=7.77 \%$} \\
\hline \multicolumn{6}{|c|}{ Test for overall effect: $Z=0.12(P=0.9)$} \\
\hline \multicolumn{6}{|c|}{ Test for subgroup differences: $\mathrm{Chi}^{2}=2.58, \mathrm{df}=1(\mathrm{P}=0.11), \mathrm{I}^{2}=61.28 \%$} \\
\hline
\end{tabular}

Analysis 1.67. Comparison 1 Glyceryl trinitrate (GTN) compared with no GTN for acute
stroke, Outcome 67 Feeding route (non-oral feeding at day 7), by time to randomisation.

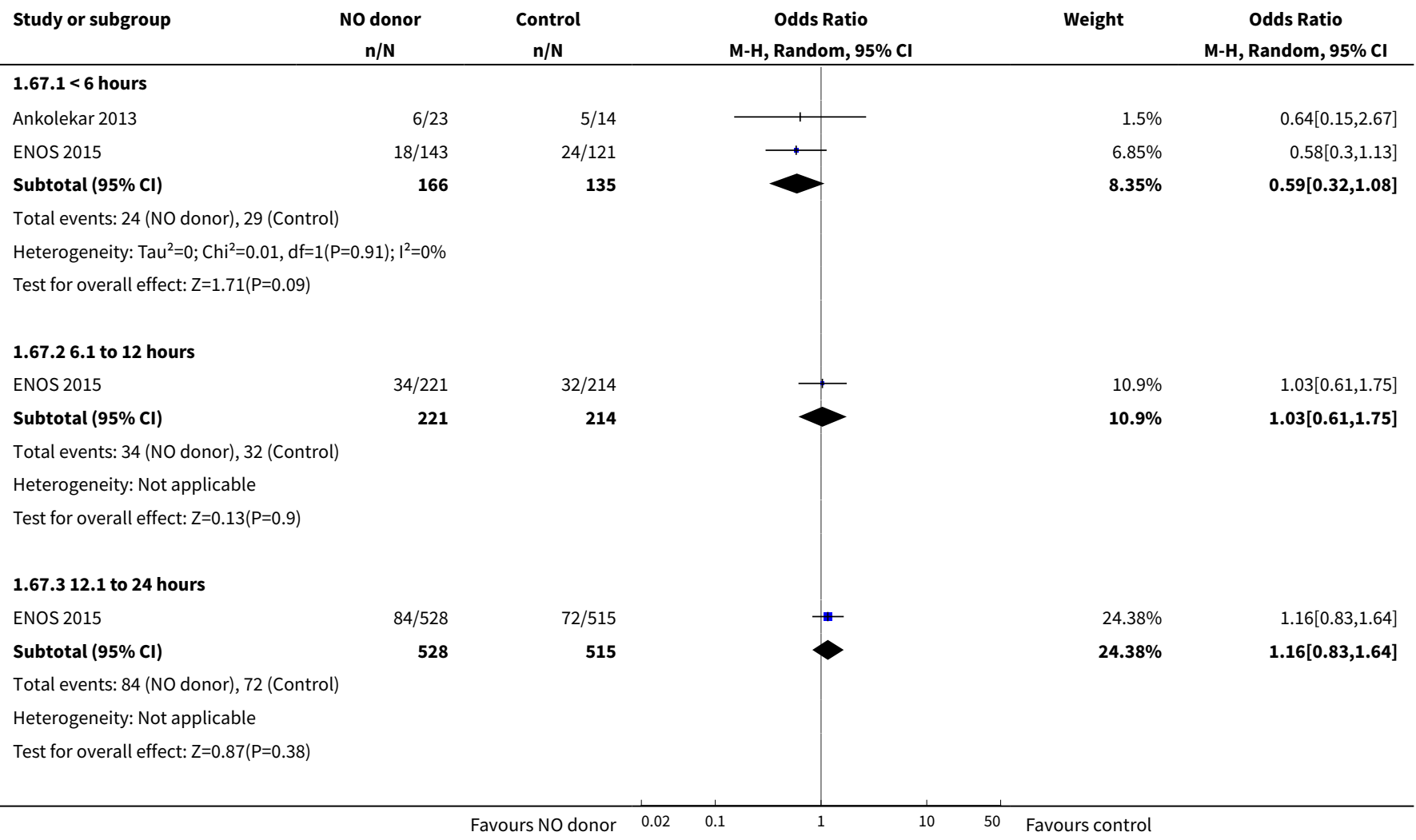




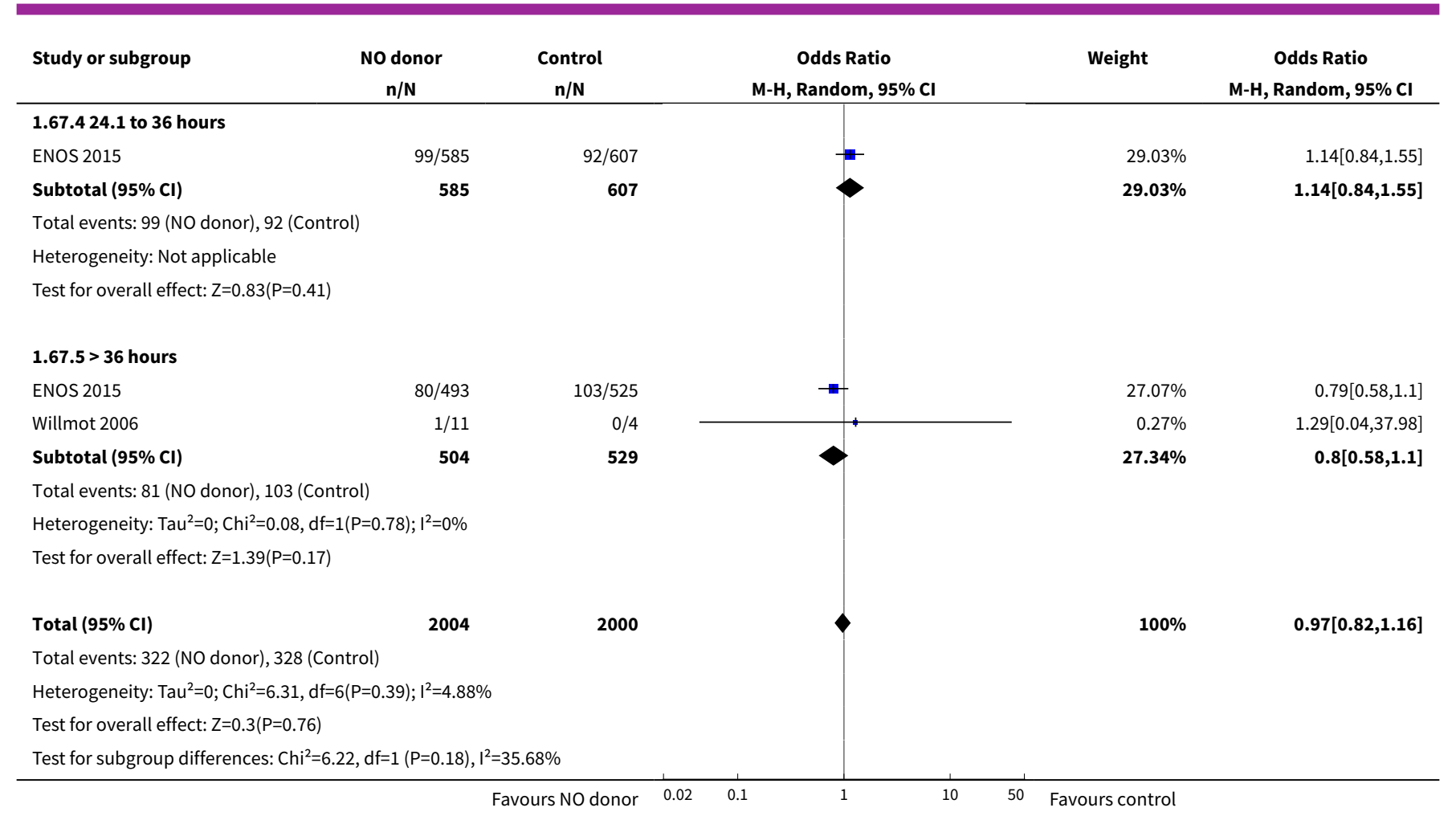

Analysis 1.68. Comparison 1 Glyceryl trinitrate (GTN) compared with no GTN for acute stroke, Outcome 68 Feeding route (non-oral feeding at day 7), by baseline SBP.

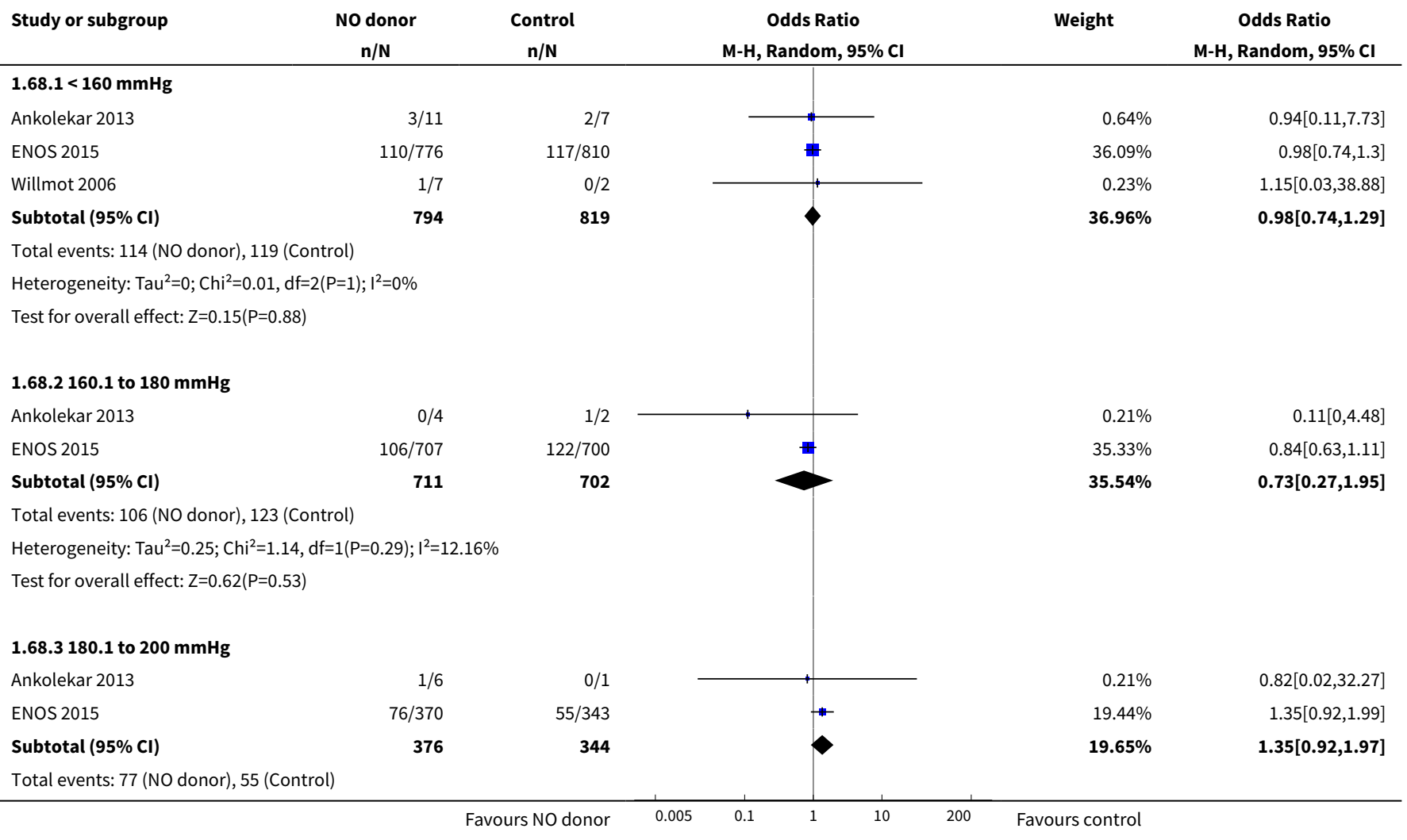




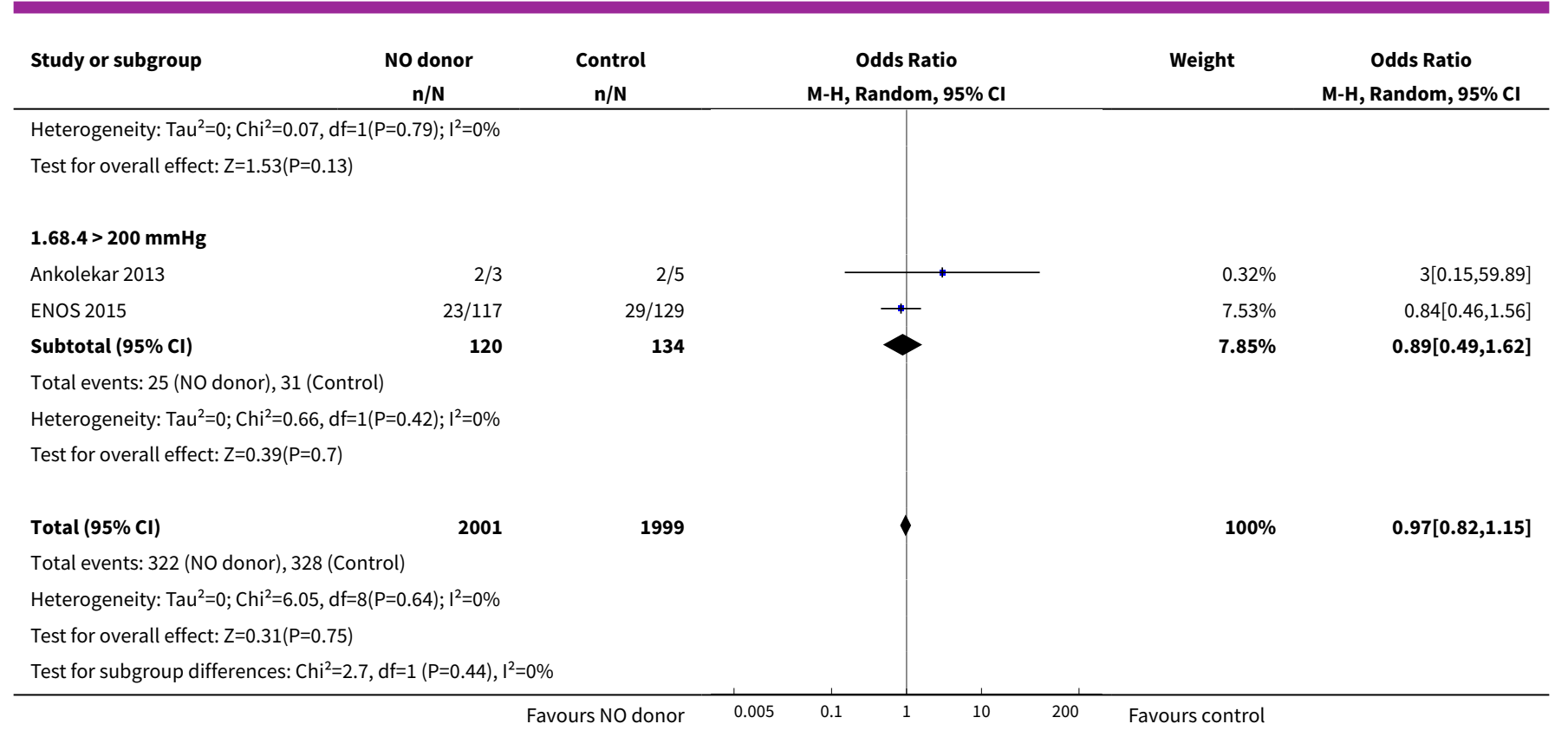

\section{Analysis 1.69. Comparison 1 Glyceryl trinitrate (GTN) compared} with no GTN for acute stroke, Outcome 69 Length of stay.

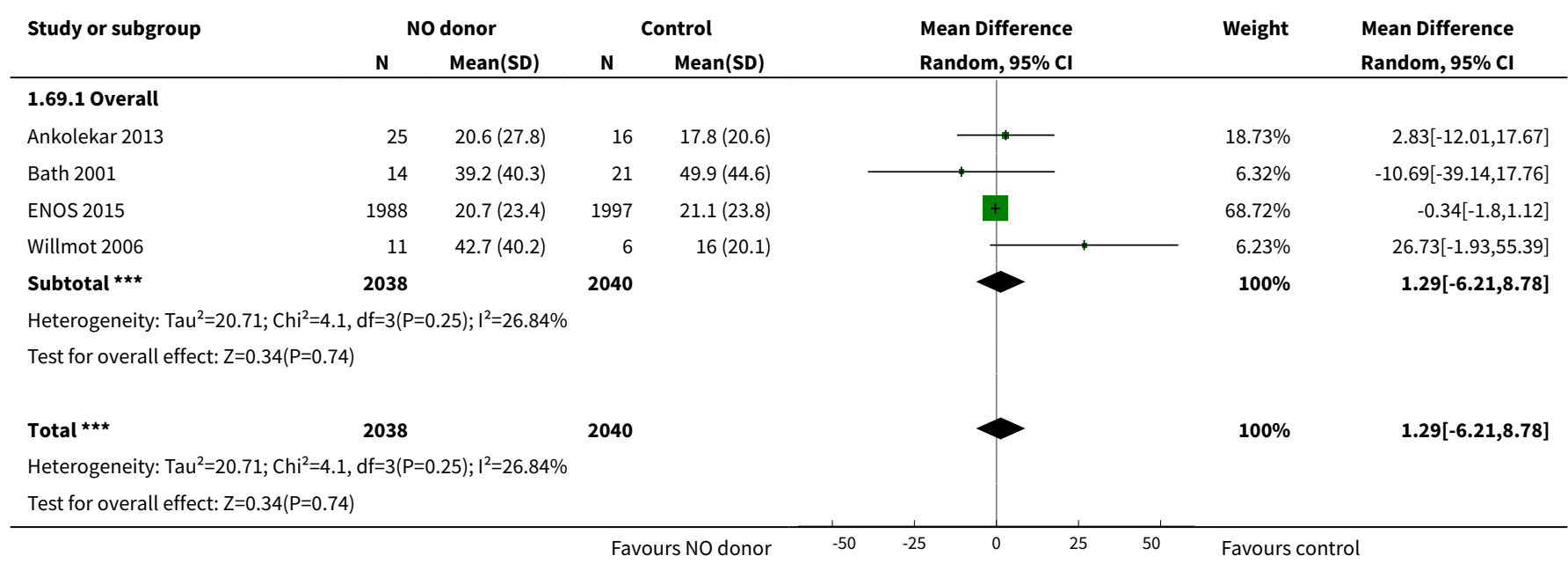

Analysis 1.70. Comparison 1 Glyceryl trinitrate (GTN) compared with no GTN for acute stroke, Outcome 70 Length of stay, by stroke type.

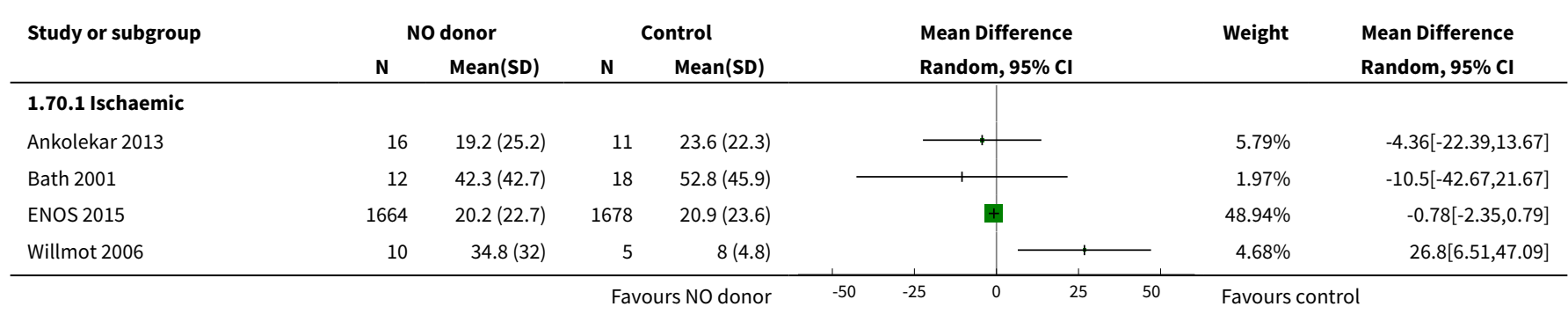




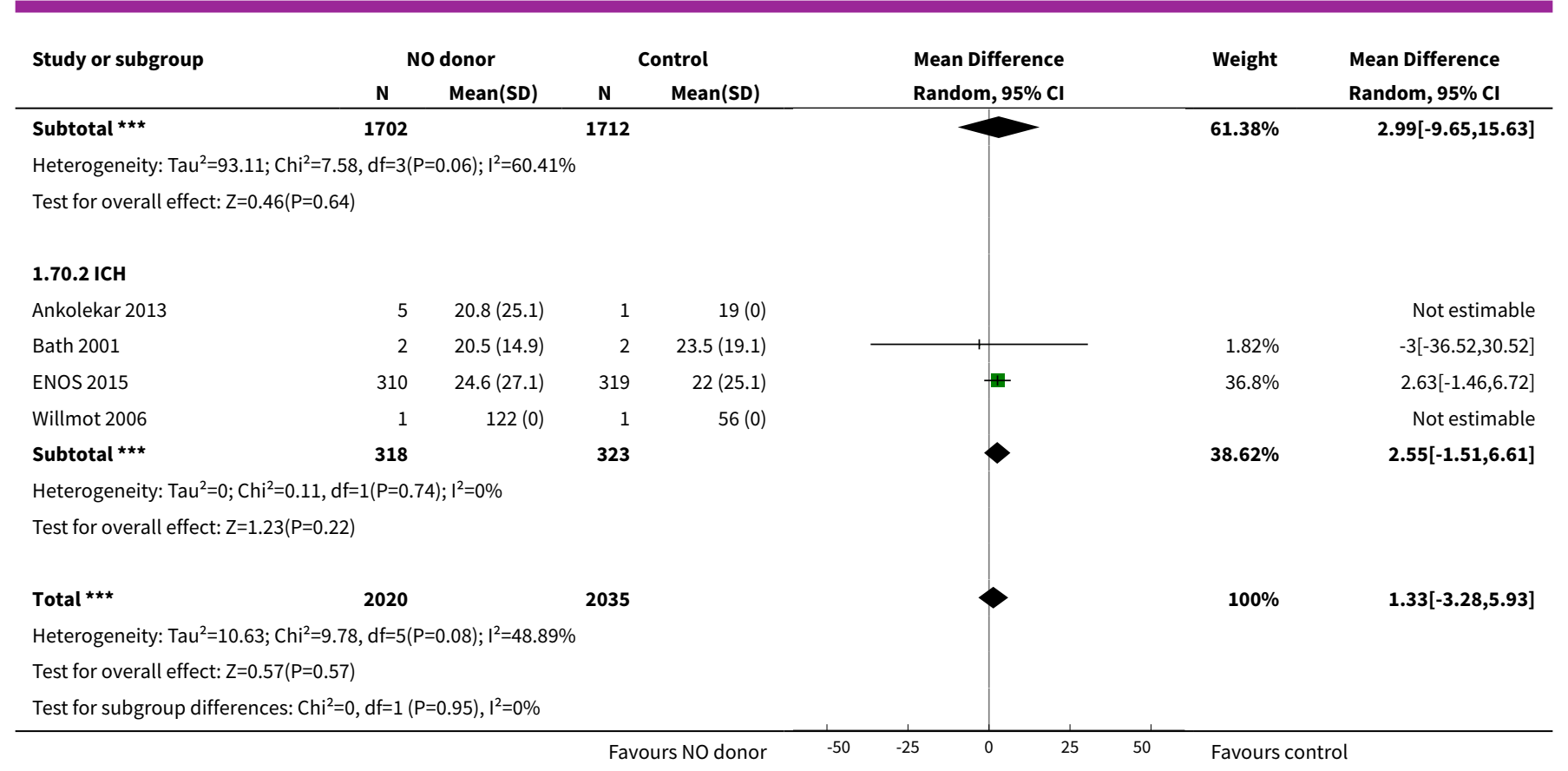

Analysis 1.71. Comparison 1 Glyceryl trinitrate (GTN) compared with no GTN for acute stroke, Outcome 71 Length of stay by time, to randomisation.

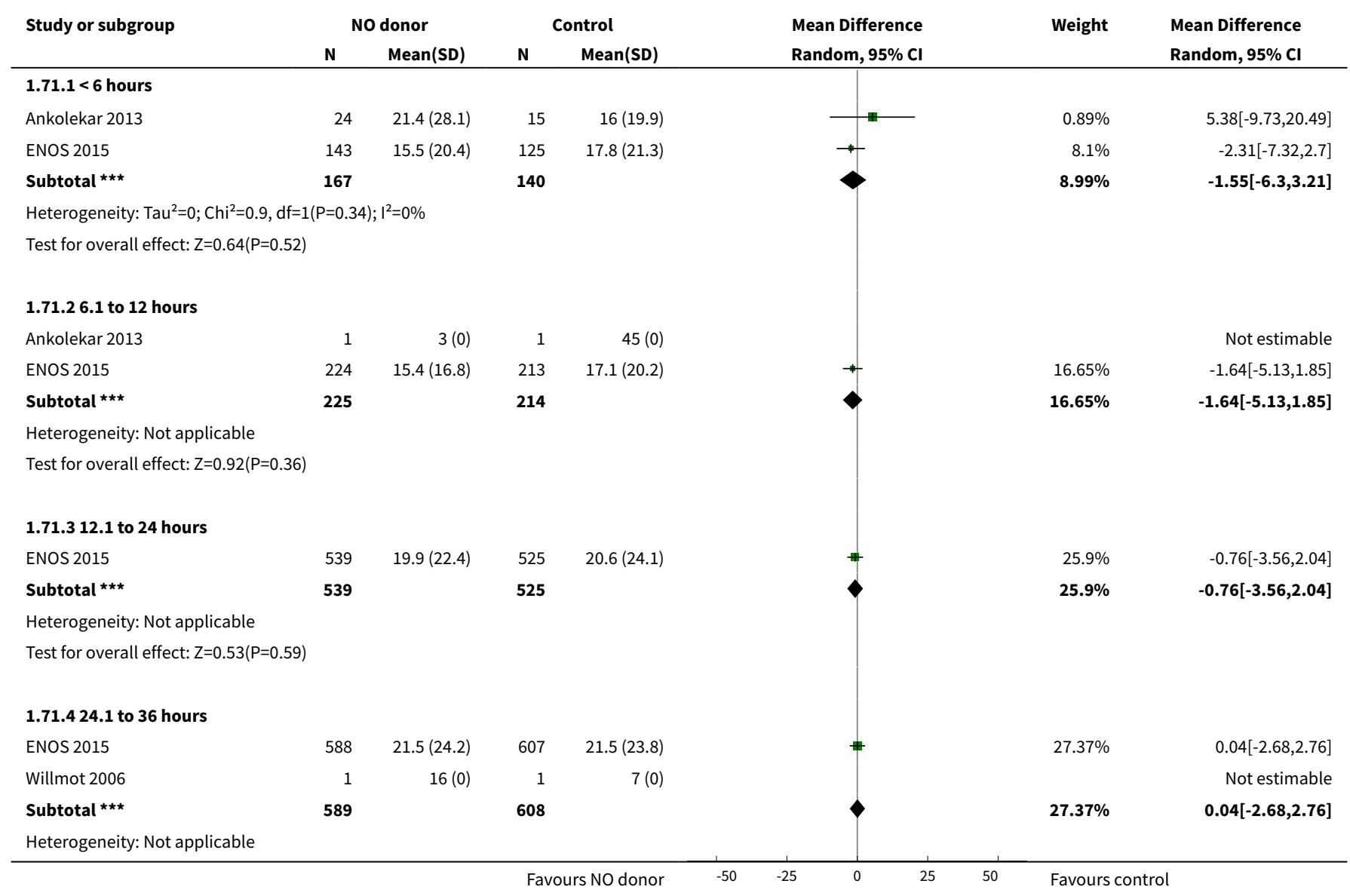




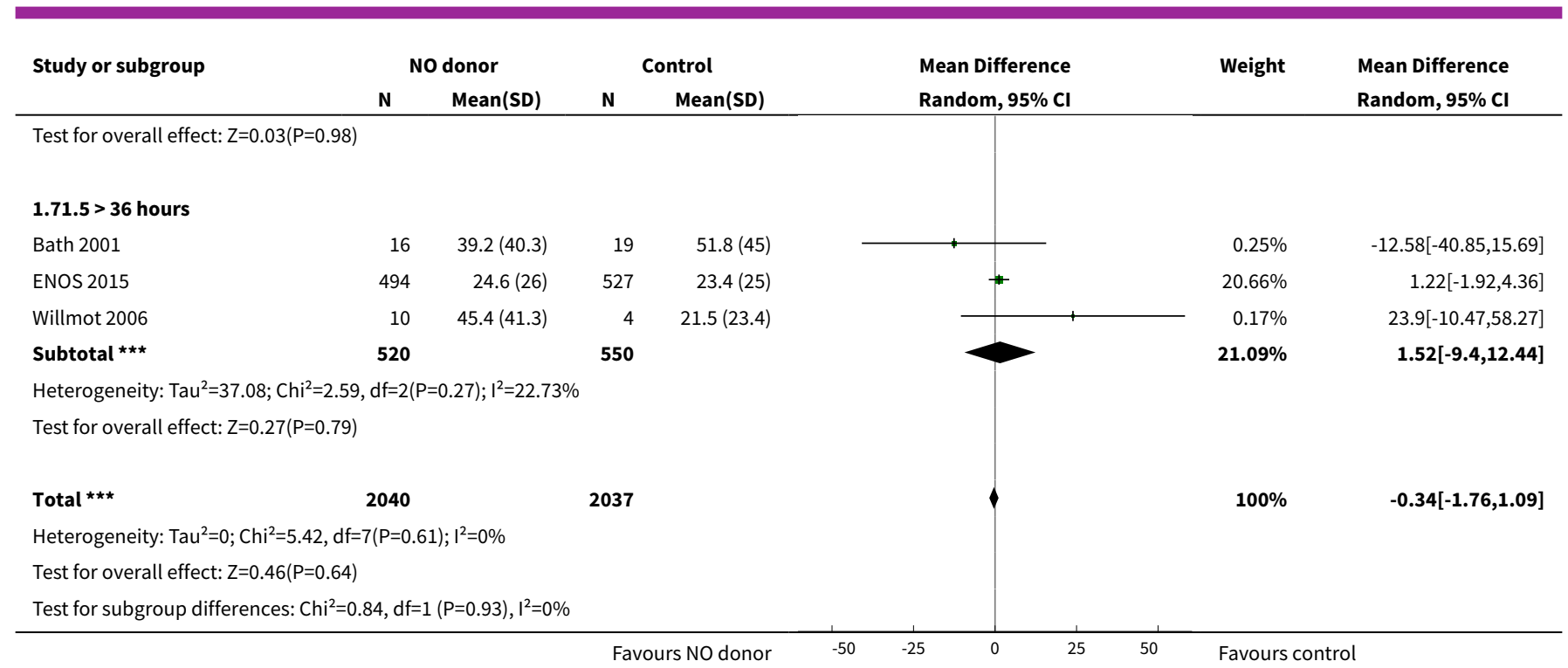

Analysis 1.72. Comparison 1 Glyceryl trinitrate (GTN) compared with no GTN for acute stroke, Outcome 72 Length of stay, by baseline SBP.

\begin{tabular}{|c|c|c|c|c|c|c|c|}
\hline \multirow{3}{*}{$\begin{array}{l}\text { Study or subgroup } \\
1.72 .1<160 \mathrm{mmHg}\end{array}$} & \multicolumn{2}{|c|}{ NO donor } & \multicolumn{2}{|c|}{ Control } & \multirow{2}{*}{$\begin{array}{l}\text { Mean Difference } \\
\text { Random, } 95 \% \mathrm{Cl}\end{array}$} & \multirow[t]{2}{*}{ Weight } & \multirow{2}{*}{$\begin{array}{l}\text { Mean Difference } \\
\text { Random, } 95 \% \mathrm{Cl}\end{array}$} \\
\hline & \multirow[t]{2}{*}{$\mathbf{N}$} & \multirow[t]{2}{*}{ Mean(SD) } & \multirow[t]{2}{*}{$\mathbf{N}$} & \multirow[t]{2}{*}{ Mean(SD) } & & & \\
\hline & & & & & & & \\
\hline Ankolekar 2013 & 11 & $25.2(28.6)$ & 7 & $21.1(25.7)$ & - & $1.29 \%$ & $4.04[-21.39,29.47]$ \\
\hline Bath 2001 & 5 & $36.4(26.6)$ & 13 & $31.3(30.4)$ & & $1.03 \%$ & $5.09[-23.52,33.7]$ \\
\hline ENOS 2015 & 783 & $18.8(20.9)$ & 816 & $20.3(23.1)$ & m & $29.64 \%$ & $-1.46[-3.62,0.7]$ \\
\hline Willmot 2006 & 7 & $57.3(43.8)$ & 2 & $11.5(6.4)$ & & $0.75 \%$ & $45.79[12.2,79.38]$ \\
\hline \multicolumn{8}{|c|}{ Heterogeneity: $\mathrm{Tau}^{2}=177.38 ; \mathrm{Chi}^{2}=7.92, \mathrm{df}=3(\mathrm{P}=0.05) ; \mathrm{I}^{2}=62.14 \%$} \\
\hline \multicolumn{8}{|c|}{ Test for overall effect: $Z=0.99(P=0.32)$} \\
\hline \multicolumn{8}{|c|}{1.72 .2160 .1 to $180 \mathrm{mmHg}$} \\
\hline Ankolekar 2013 & 4 & $2.5(1.9)$ & 3 & $17.7(16.1)$ & & $2.42 \%$ & $-15.17[-33.45,3.11]$ \\
\hline Bath 2001 & 6 & $19.5(9.9)$ & 4 & $65.5(51.3)$ & + & $0.33 \%$ & $-46[-96.93,4.93]$ \\
\hline Willmot 2006 & 2 & $24(18.4)$ & 3 & $5.7(2.3)$ & & $1.27 \%$ & $18.33[-7.28,43.94]$ \\
\hline Subtotal $\star \star \star$ & 725 & & 718 & & & $32.37 \%$ & $-3.77[-18.94,11.4]$ \\
\hline \multicolumn{8}{|c|}{ Heterogeneity: $\mathrm{Tau}^{2}=130.93 ; \mathrm{Chi}^{2}=7.83, \mathrm{df}=3(\mathrm{P}=0.05) ; \mathrm{I}^{2}=61.68 \%$} \\
\hline \multicolumn{8}{|c|}{ Test for overall effect: $Z=0.49(P=0.63)$} \\
\hline \multicolumn{8}{|c|}{1.72 .3180 .1 to $200 \mathrm{mmHg}$} \\
\hline Ankolekar 2013 & 7 & $16.9(21.7)$ & 1 & $3(0)$ & & & Not estimable \\
\hline Bath 2001 & 2 & $121.5(29)$ & 2 & $124(36.8)$ & & $0.2 \%$ & $-2.5[-67.39,62.39]$ \\
\hline ENOS 2015 & 374 & $22.9(24.5)$ & 344 & $24(25.8)$ & * & $22.69 \%$ & $-1.17[-4.86,2.52]$ \\
\hline Willmot 2006 & 2 & $10.5(7.8)$ & 1 & $56(0)$ & & & Not estimable \\
\hline Subtotal ${ }^{\star \star \star}$ & 385 & & 348 & & $\diamond$ & $22.9 \%$ & $-1.17[-4.86,2.51]$ \\
\hline \multicolumn{8}{|c|}{ Heterogeneity: $\operatorname{Tau}^{2}=0 ; \mathrm{Chi}^{2}=0, \mathrm{df}=1(\mathrm{P}=0.97) ; \mathrm{I}^{2}=0 \%$} \\
\hline \multicolumn{8}{|c|}{ Test for overall effect: $\mathrm{Z}=0.62(\mathrm{P}=0.53)$} \\
\hline & & & Fav & s NO donor & $-50-25$ & Favours & \\
\hline
\end{tabular}




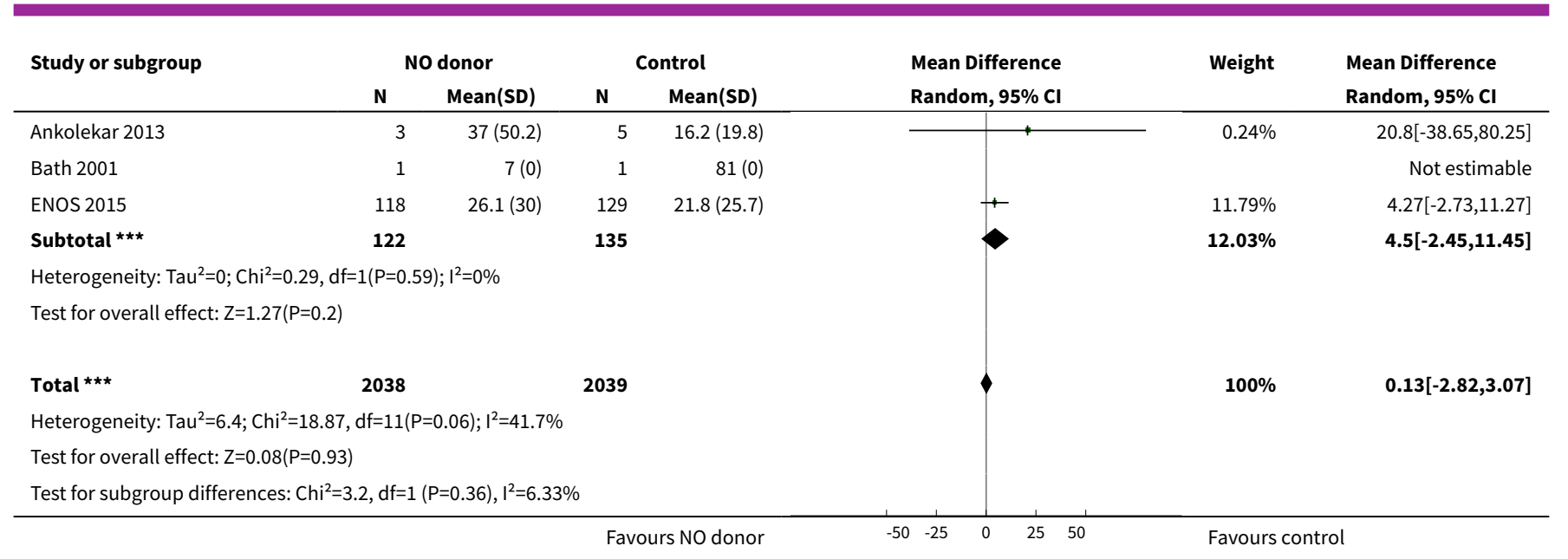

Analysis 1.73. Comparison 1 Glyceryl trinitrate (GTN) compared with no GTN for acute stroke, Outcome 73 Headache, on treatment.

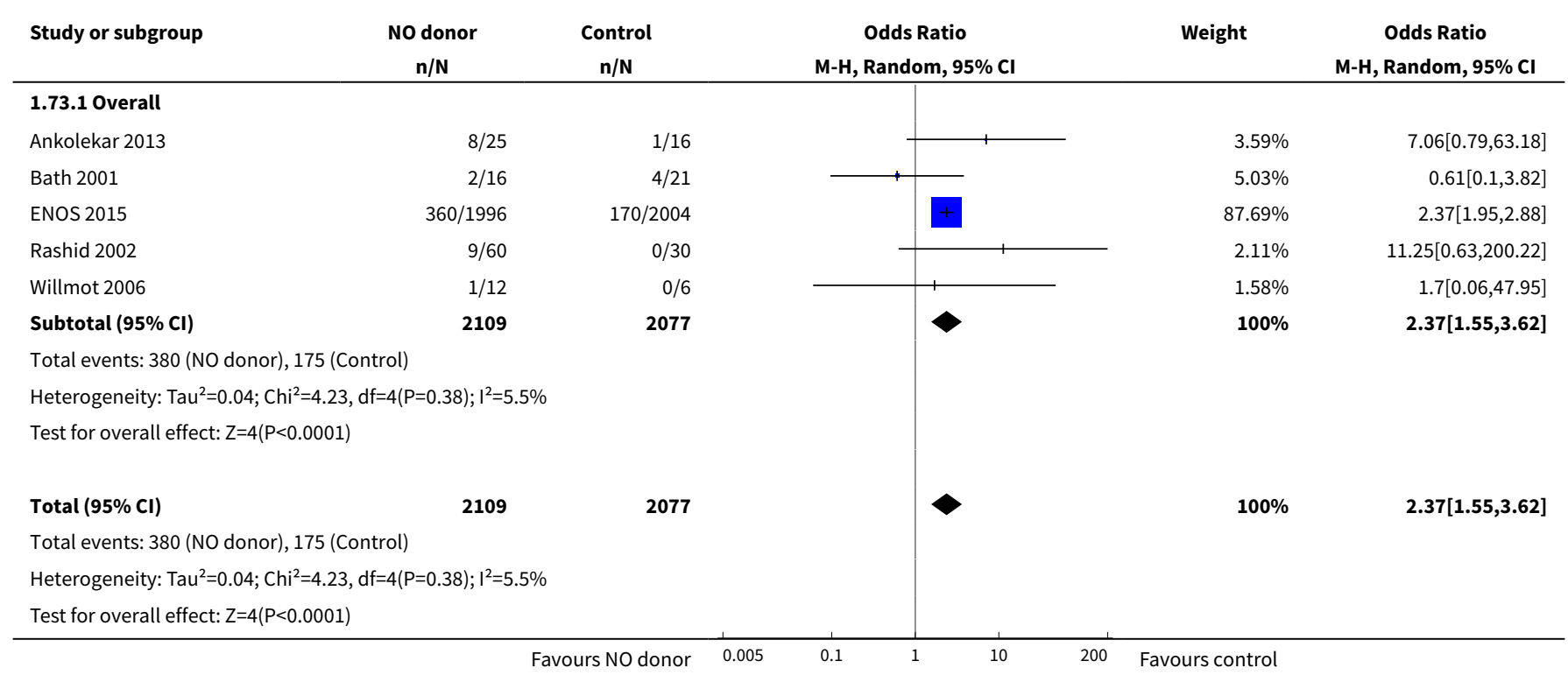

Analysis 1.74. Comparison 1 Glyceryl trinitrate (GTN) compared with no GTN for acute stroke, Outcome $\mathbf{7 4}$ Headache, on treatment, by stroke type.

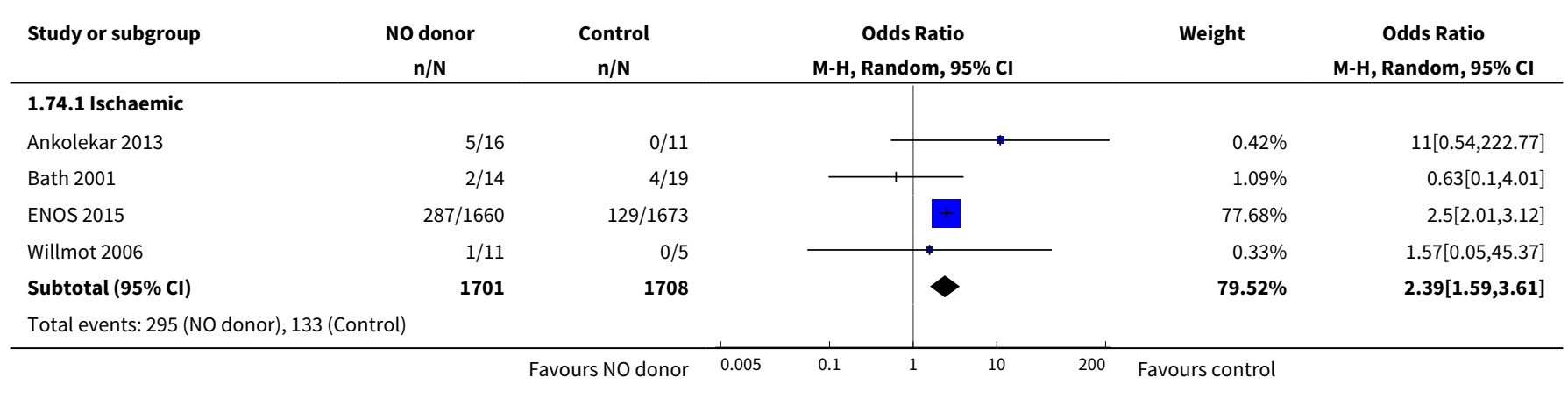




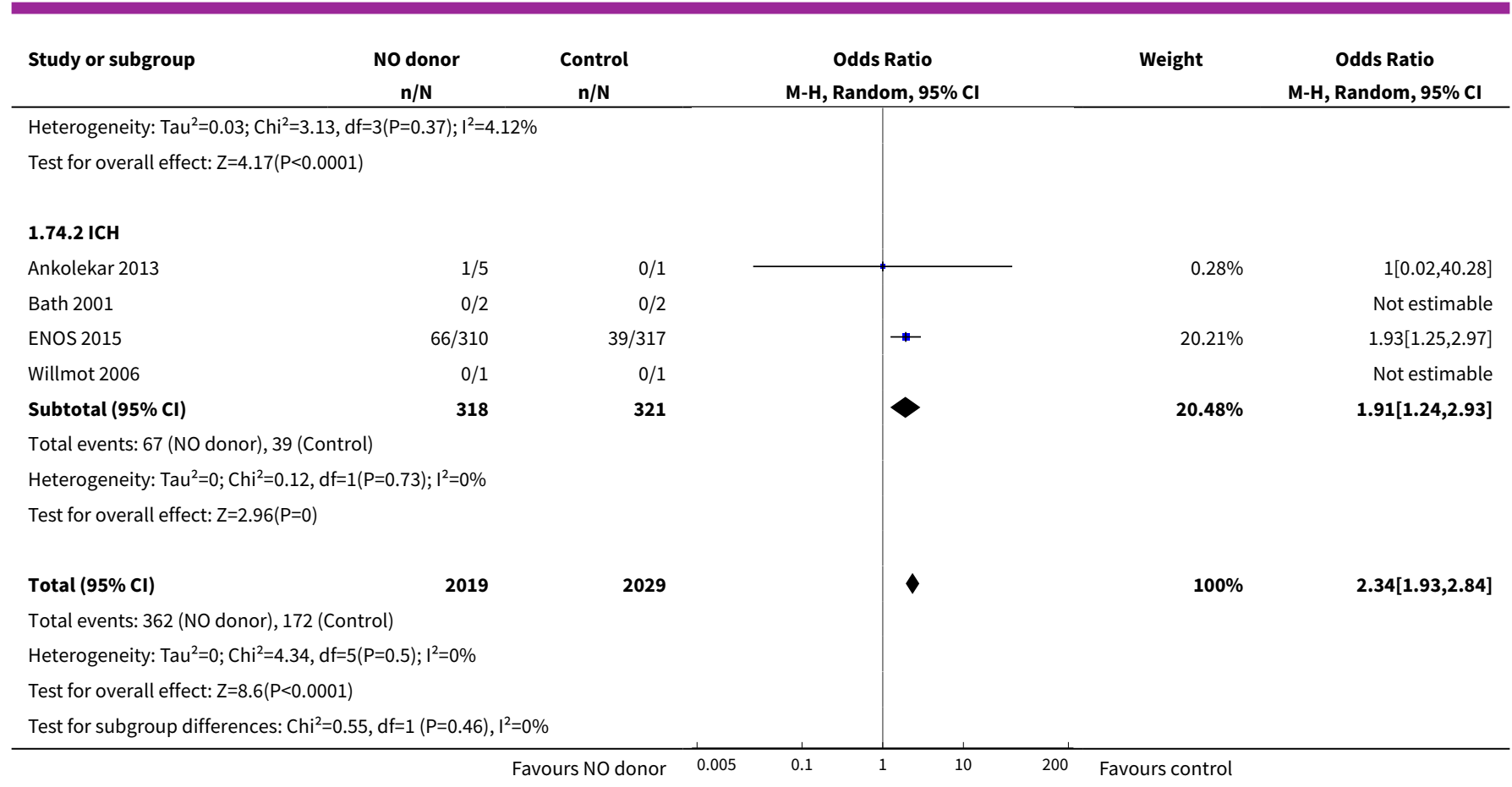

\section{Analysis 1.75. Comparison 1 Glyceryl trinitrate (GTN) compared with no GTN for acute stroke, Outcome 75 Headache, on treatment, by time to randomisation.}

\begin{tabular}{|c|c|c|c|c|c|c|}
\hline \multirow{2}{*}{$\begin{array}{l}\text { Study or subgroup } \\
1.75 .1<6 \text { hours }\end{array}$} & \multirow[t]{2}{*}{$\begin{array}{c}\text { NO donor } \\
n / N\end{array}$} & \multirow{2}{*}{\multicolumn{2}{|c|}{$\begin{array}{c}\text { Control } \\
\mathrm{n} / \mathrm{N}\end{array}$}} & $\begin{array}{c}\text { Odds Ratio } \\
\text { M-H, Random, } 95 \% \mathrm{Cl}\end{array}$ & \multirow[t]{2}{*}{ Weight } & \multirow[t]{2}{*}{$\begin{array}{c}\text { Odds Ratio } \\
\text { M-H, Random, } 95 \% \mathrm{Cl}\end{array}$} \\
\hline & & & & & & \\
\hline Ankolekar 2013 & $7 / 24$ & $1 / 15$ & & -1 & $0.75 \%$ & $5.76[0.63,52.63]$ \\
\hline ENOS 2015 & $25 / 144$ & $12 / 126$ & & $\longrightarrow$ & $6.84 \%$ & $2[0.96,4.16]$ \\
\hline Subtotal $(95 \% \mathrm{Cl})$ & 168 & 141 & & & $7.59 \%$ & $2.22[1.1,4.45]$ \\
\hline \multicolumn{7}{|c|}{ Total events: 32 (NO donor), 13 (Control) } \\
\hline \multicolumn{7}{|c|}{ Heterogeneity: Tau $^{2}=0 ; \mathrm{Chi}^{2}=0.8, \mathrm{df}=1(\mathrm{P}=0.37) ; \mathrm{I}^{2}=0 \%$} \\
\hline \multicolumn{7}{|c|}{ Test for overall effect: $\mathrm{Z}=2.24(\mathrm{P}=0.03)$} \\
\hline \multicolumn{7}{|c|}{ 1.75.2 6.1 to 12 hours } \\
\hline Ankolekar 2013 & $1 / 1$ & $0 / 1$ & & & $0.18 \%$ & $9[0.1,831.78]$ \\
\hline ENOS 2015 & $37 / 224$ & $19 / 214$ & & $\rightarrow$ & $10.66 \%$ & $2.03[1.13,3.66]$ \\
\hline Subtotal $(95 \% \mathrm{Cl})$ & 225 & 215 & & & $10.84 \%$ & $2.08[1.16,3.73]$ \\
\hline \multicolumn{7}{|c|}{ Heterogeneity: $\operatorname{Tau}^{2}=0 ; \mathrm{Chi}^{2}=0.41, \mathrm{df}=1(\mathrm{P}=0.52) ; \mathrm{I}^{2}=0 \%$} \\
\hline \multicolumn{7}{|c|}{ Test for overall effect: $Z=2.46(P=0.01)$} \\
\hline \multicolumn{7}{|c|}{ 1.75.3 12.1 to 24 hours } \\
\hline ENOS 2015 & $109 / 540$ & $47 / 525$ & & $\rightarrow$ & $27.56 \%$ & $2.57[1.78,3.71]$ \\
\hline Subtotal $(95 \% \mathrm{Cl})$ & 540 & 525 & & & $27.56 \%$ & $2.57[1.78,3.71]$ \\
\hline \multicolumn{7}{|c|}{ Total events: 109 (NO donor), 47 (Control) } \\
\hline \multicolumn{7}{|c|}{ Heterogeneity: Not applicable } \\
\hline \multicolumn{7}{|c|}{ Test for overall effect: $Z=5.06(P<0.0001)$} \\
\hline 1.75.4 24.1 to 36 ho & & & & & & \\
\hline
\end{tabular}




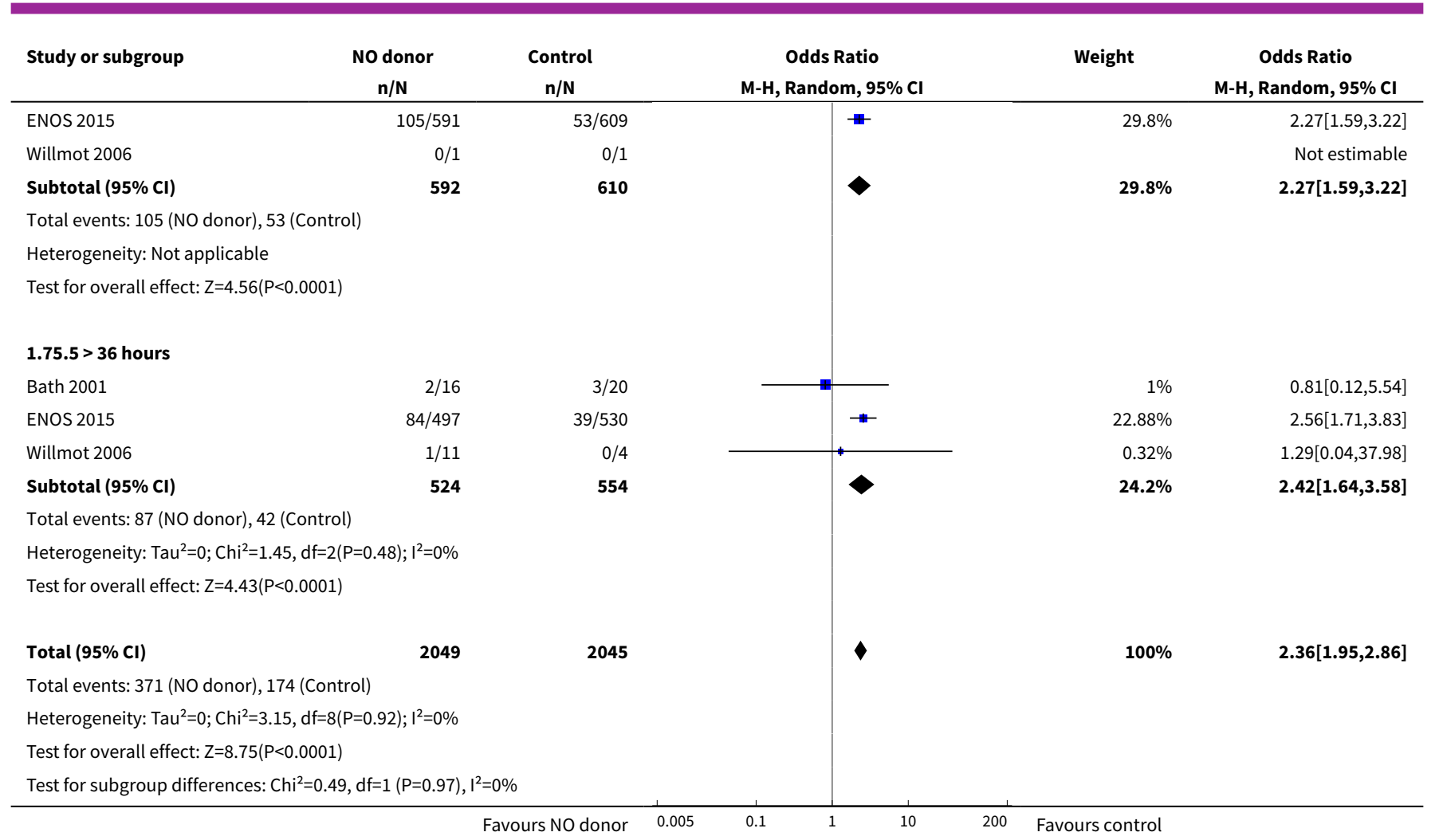

Analysis 1.76. Comparison 1 Glyceryl trinitrate (GTN) compared with no GTN for acute stroke, Outcome 76 Headache, on treatment, by baseline SBP.

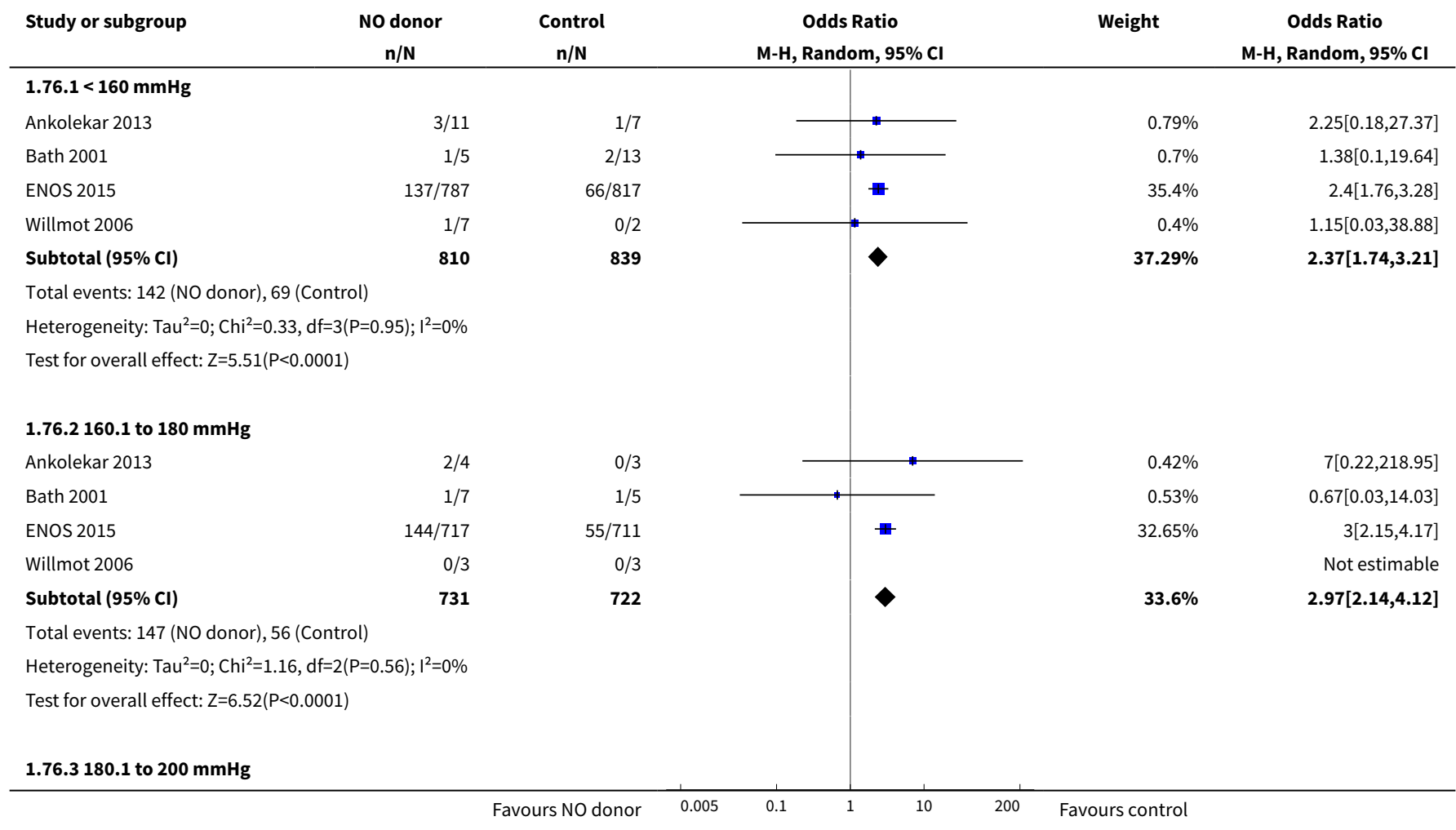




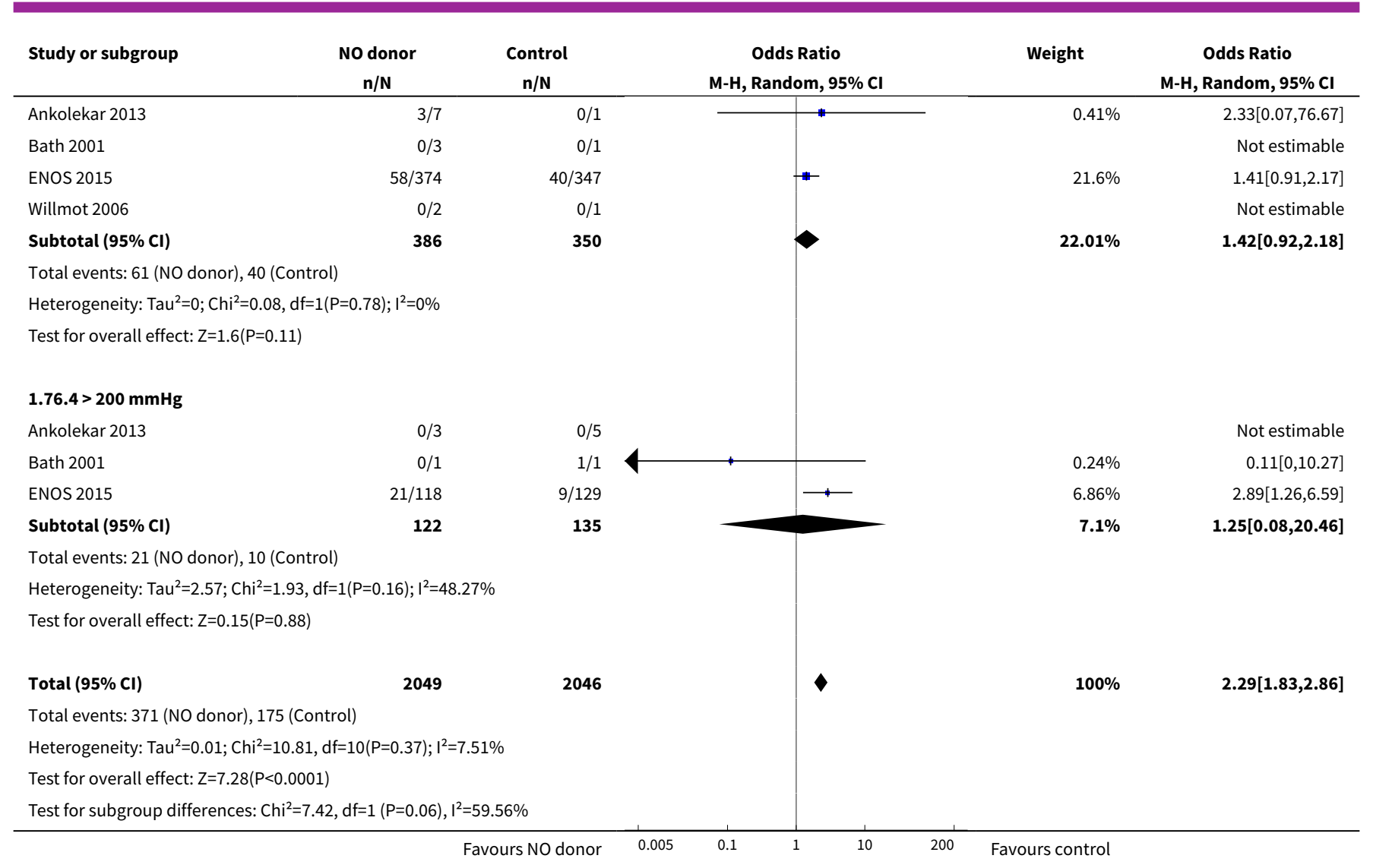

Analysis 1.77. Comparison 1 Glyceryl trinitrate (GTN) compared with no GTN for acute stroke, Outcome 77 Treatment stopped early.

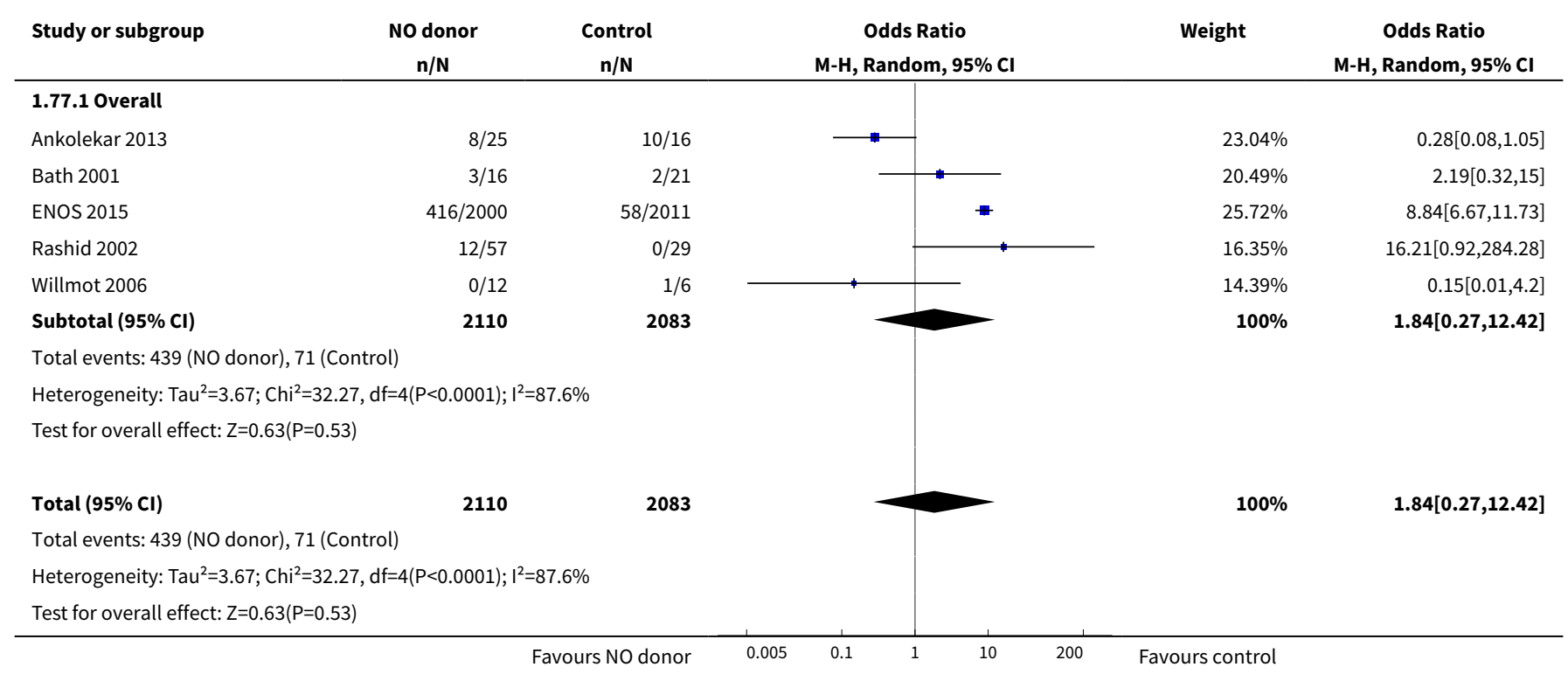


Analysis 1.78. Comparison 1 Glyceryl trinitrate (GTN) compared with no GTN for acute stroke, Outcome 78 Treatment stopped early, by stroke type.

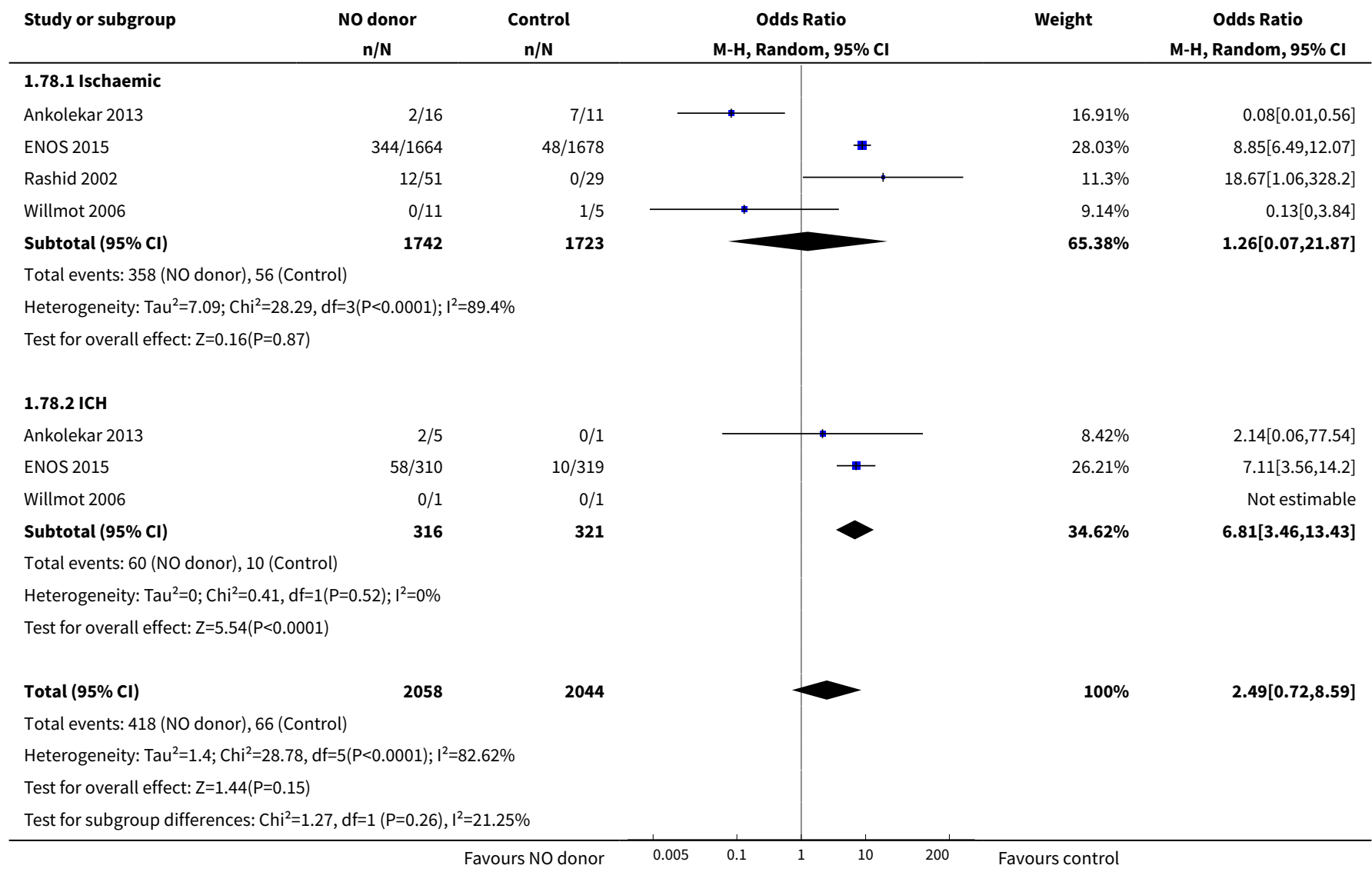

Analysis 1.79. Comparison 1 Glyceryl trinitrate (GTN) compared with no GTN for acute stroke, Outcome 79 Treatment stopped early, by time to randomisation.

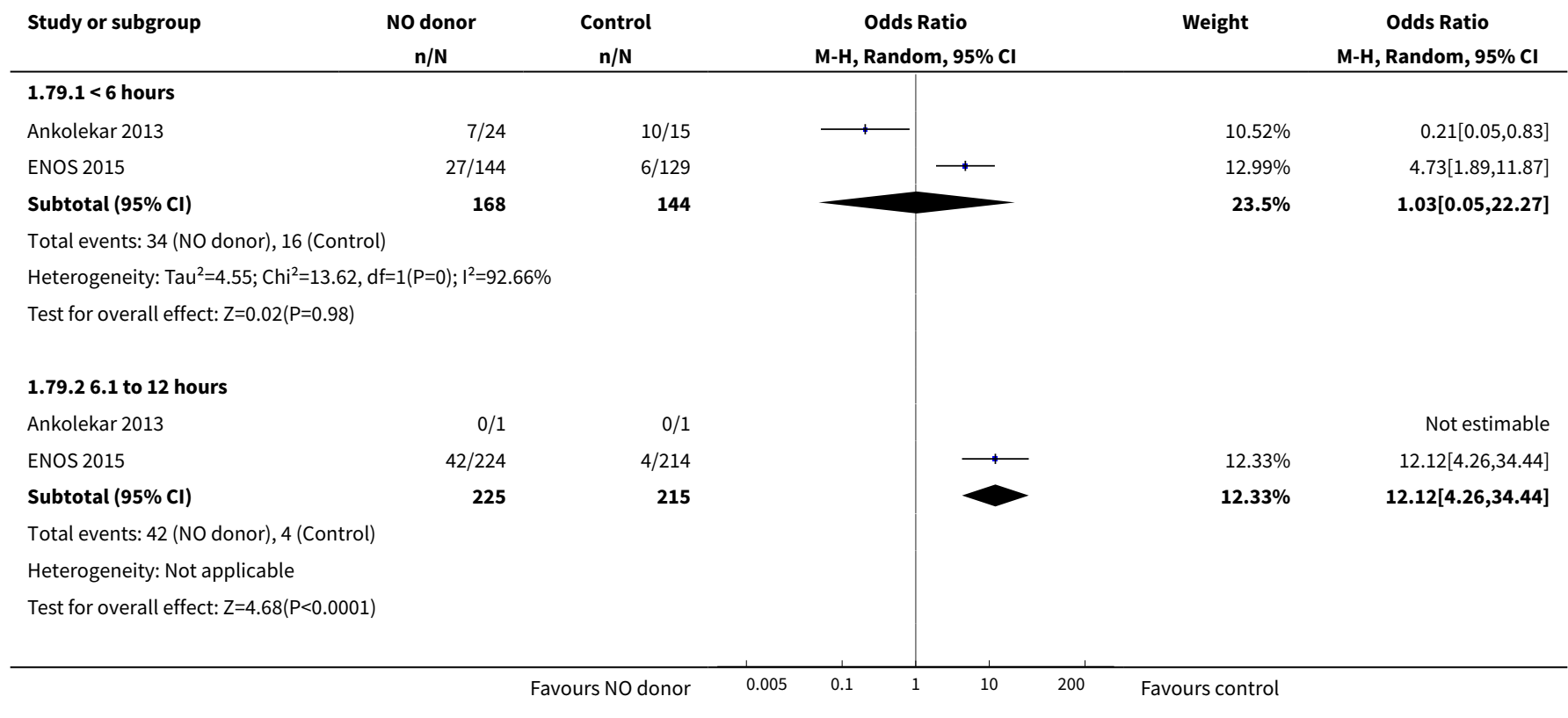




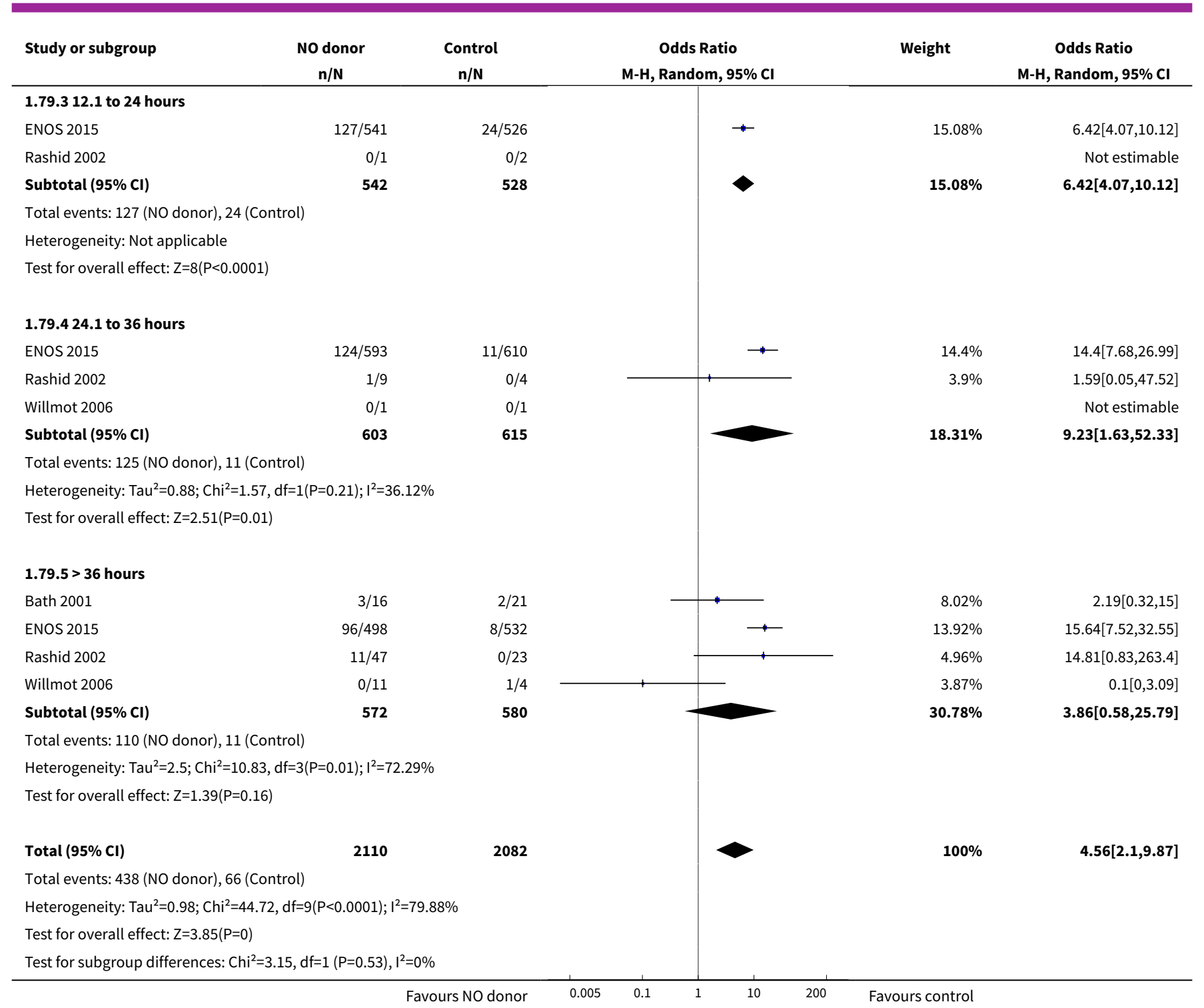

Analysis 1.80. Comparison 1 Glyceryl trinitrate (GTN) compared with no GTN for acute stroke, Outcome 80 Treatment stopped early, by baseline SBP.

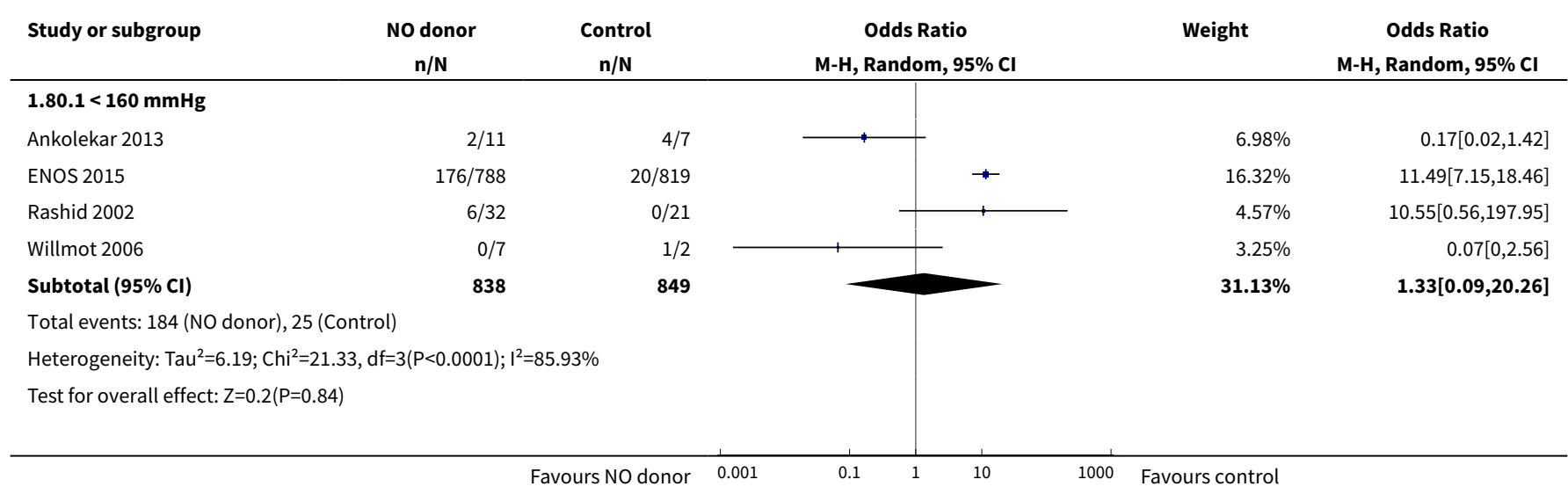




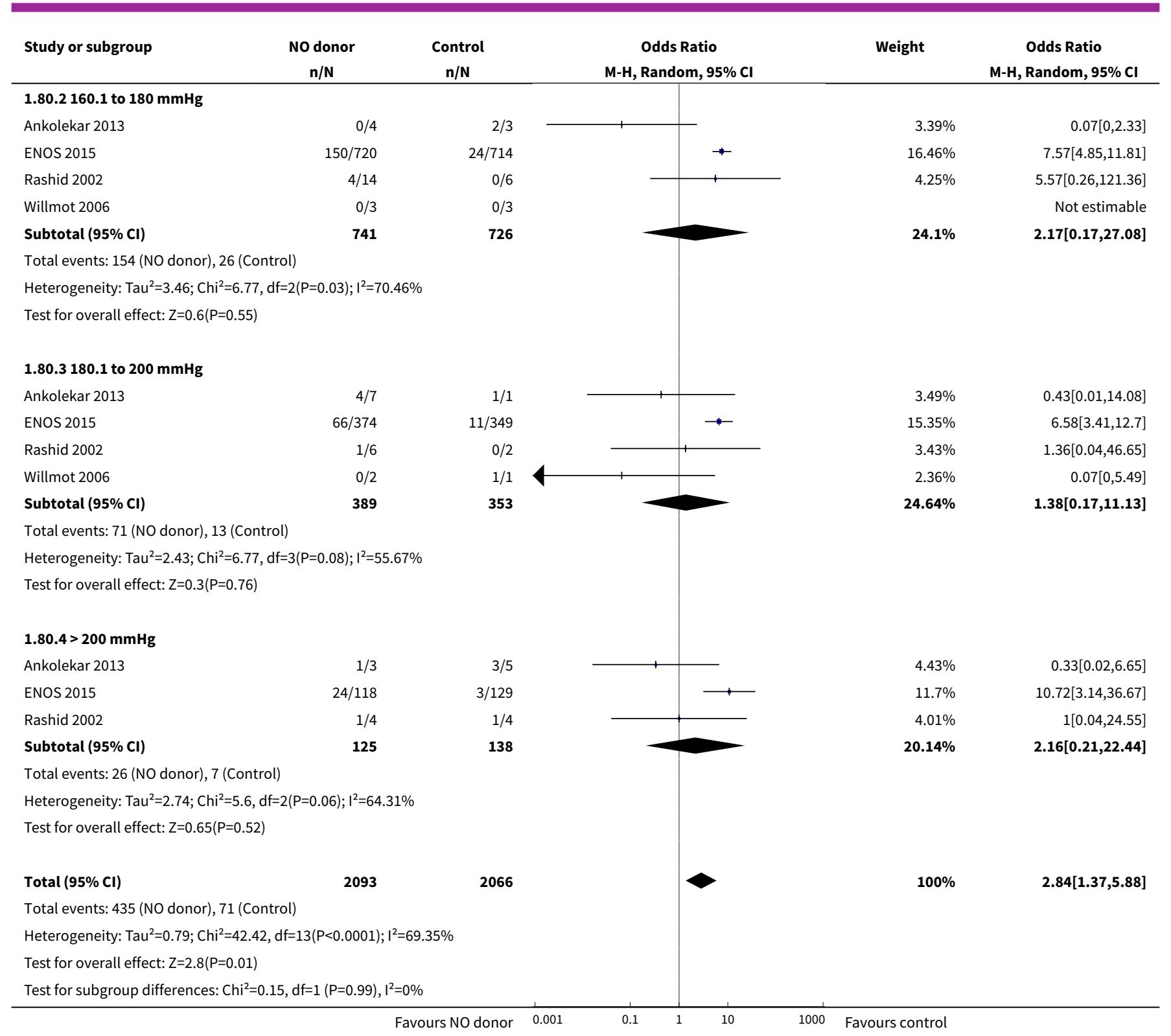

Analysis 1.81. Comparison 1 Glyceryl trinitrate (GTN) compared with no GTN for acute stroke, Outcome 81 Systolic BP, first treatment measurement.

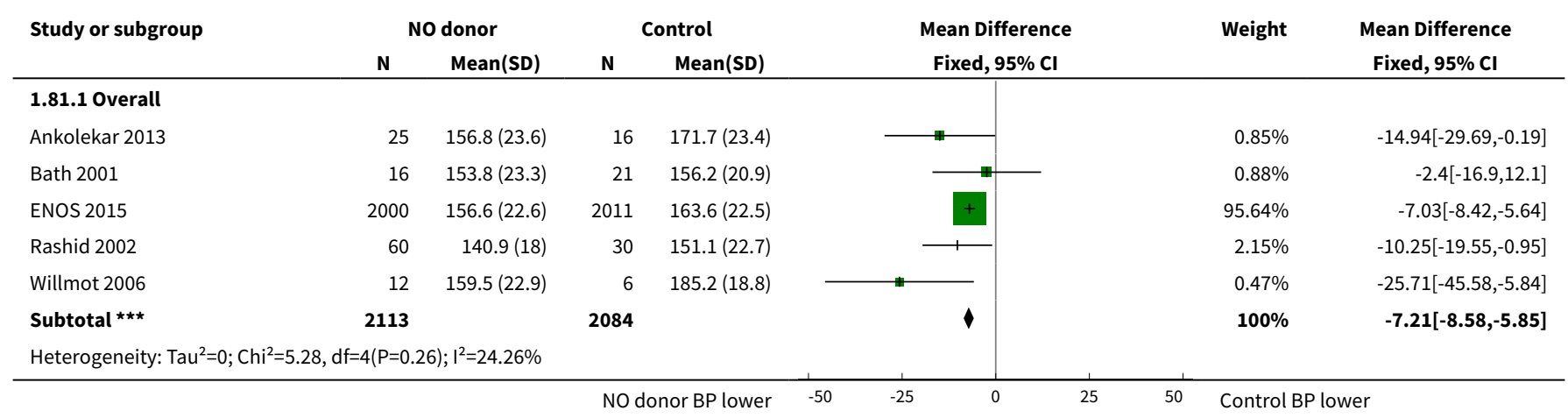




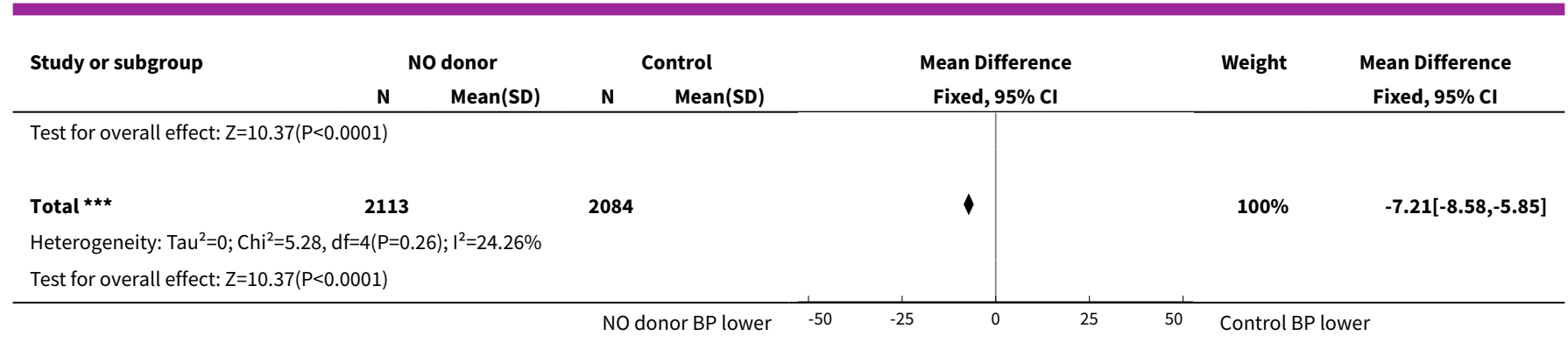

Analysis 1.82. Comparison 1 Glyceryl trinitrate (GTN) compared with no GTN for acute stroke, Outcome 82 Systolic BP, first treatment measurement, by stroke type.

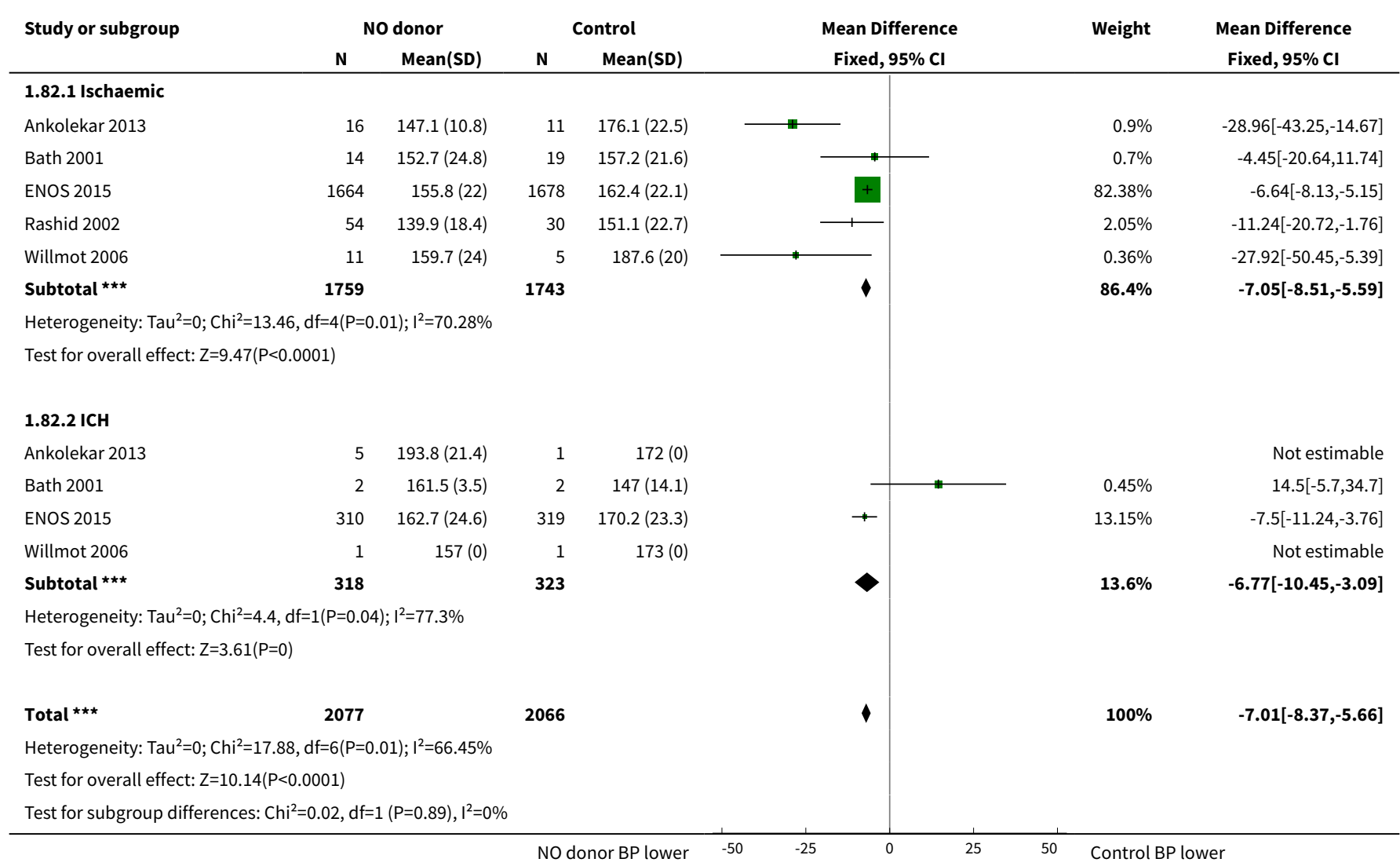

Analysis 1.83. Comparison 1 Glyceryl trinitrate (GTN) compared with no GTN for acute stroke, Outcome 83 Systolic BP, first treatment measurement, by time to randomisation.

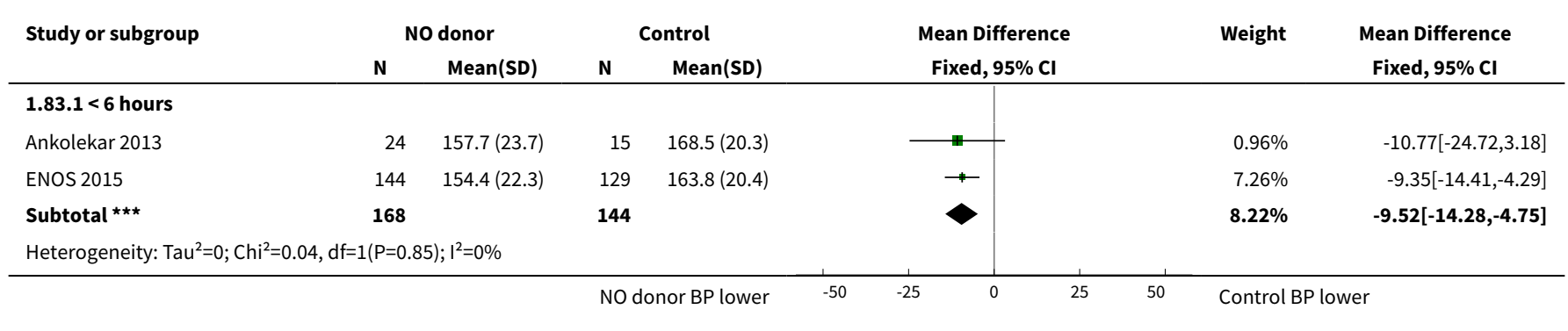




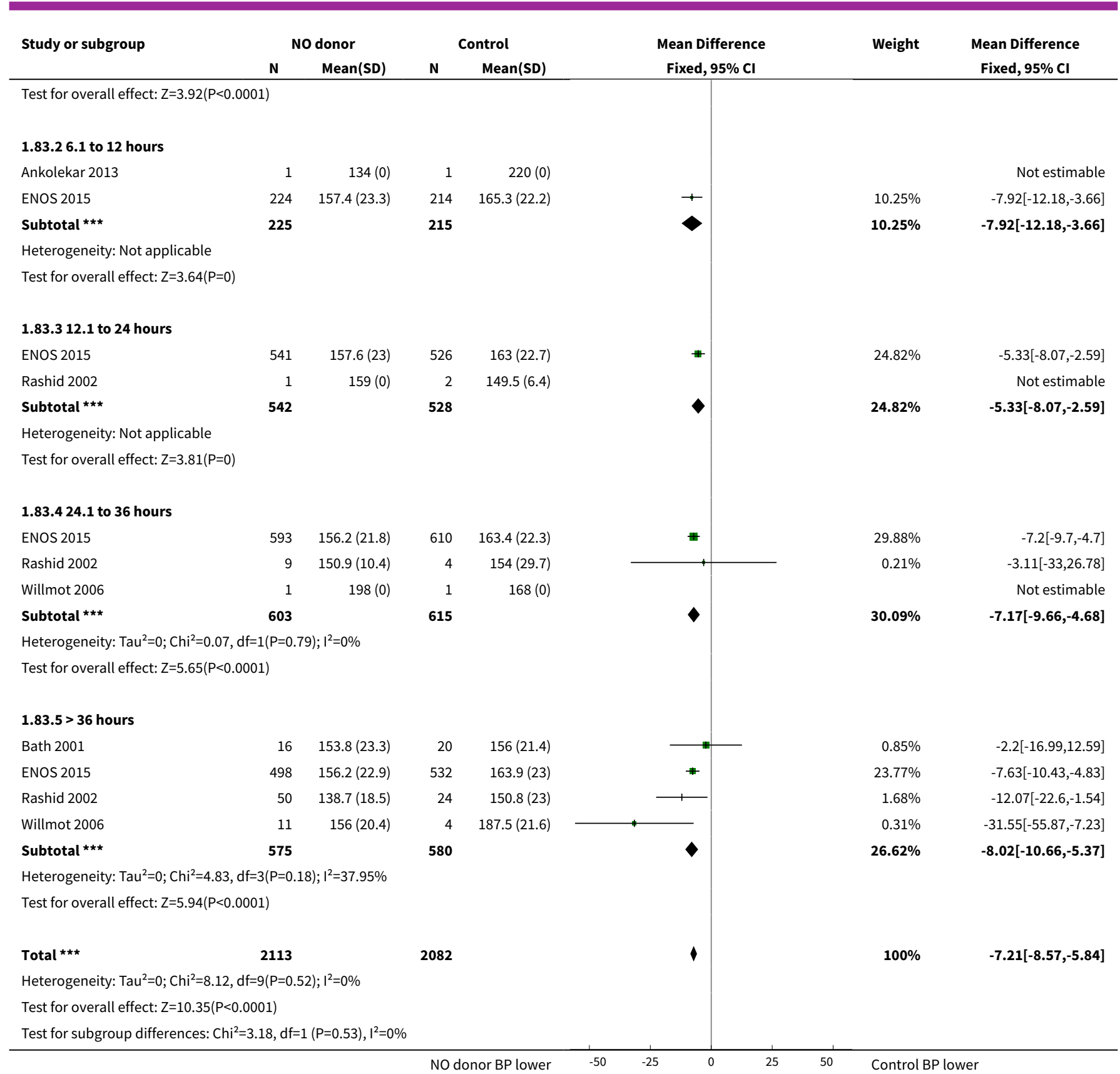

Analysis 1.84. Comparison 1 Glyceryl trinitrate (GTN) compared with no GTN for acute stroke, Outcome 84 Diastolic BP, first treatment measurement.

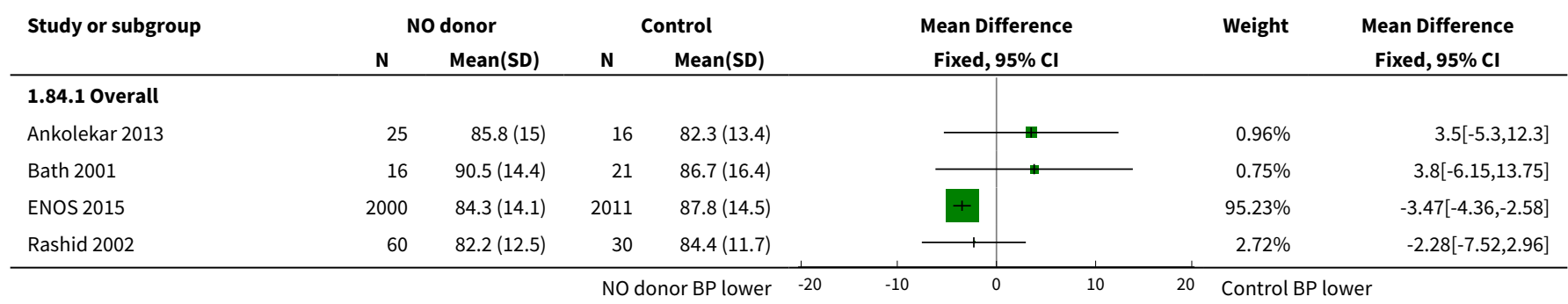




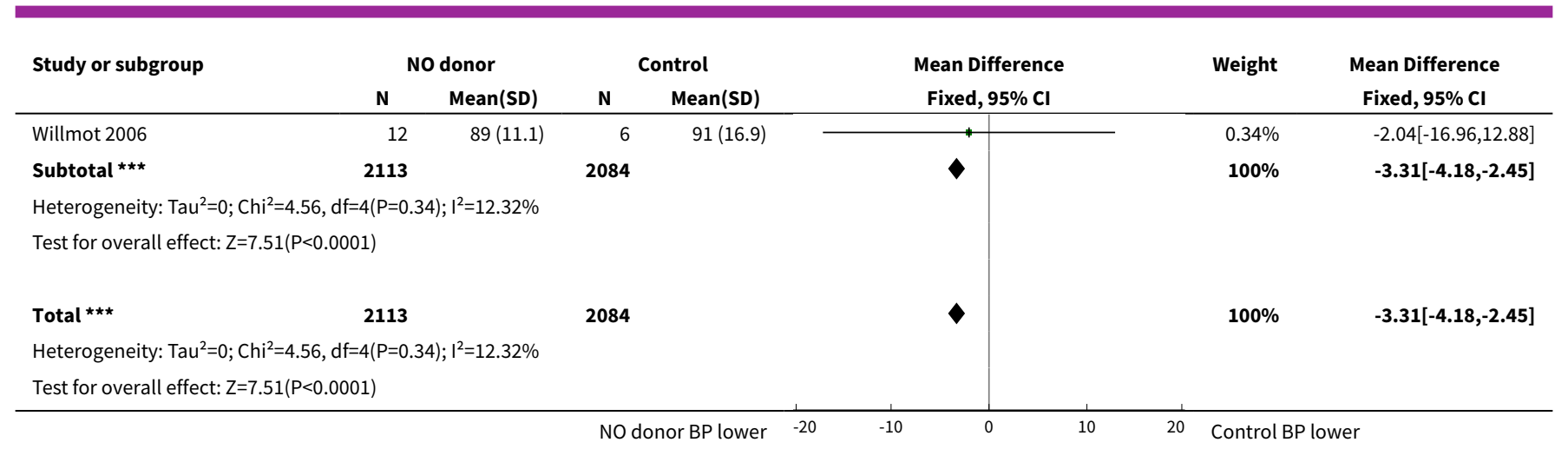

Analysis 1.85. Comparison 1 Glyceryl trinitrate (GTN) compared with no GTN for acute stroke, Outcome 85 Diastolic BP, first treatment measurement, by stroke type.

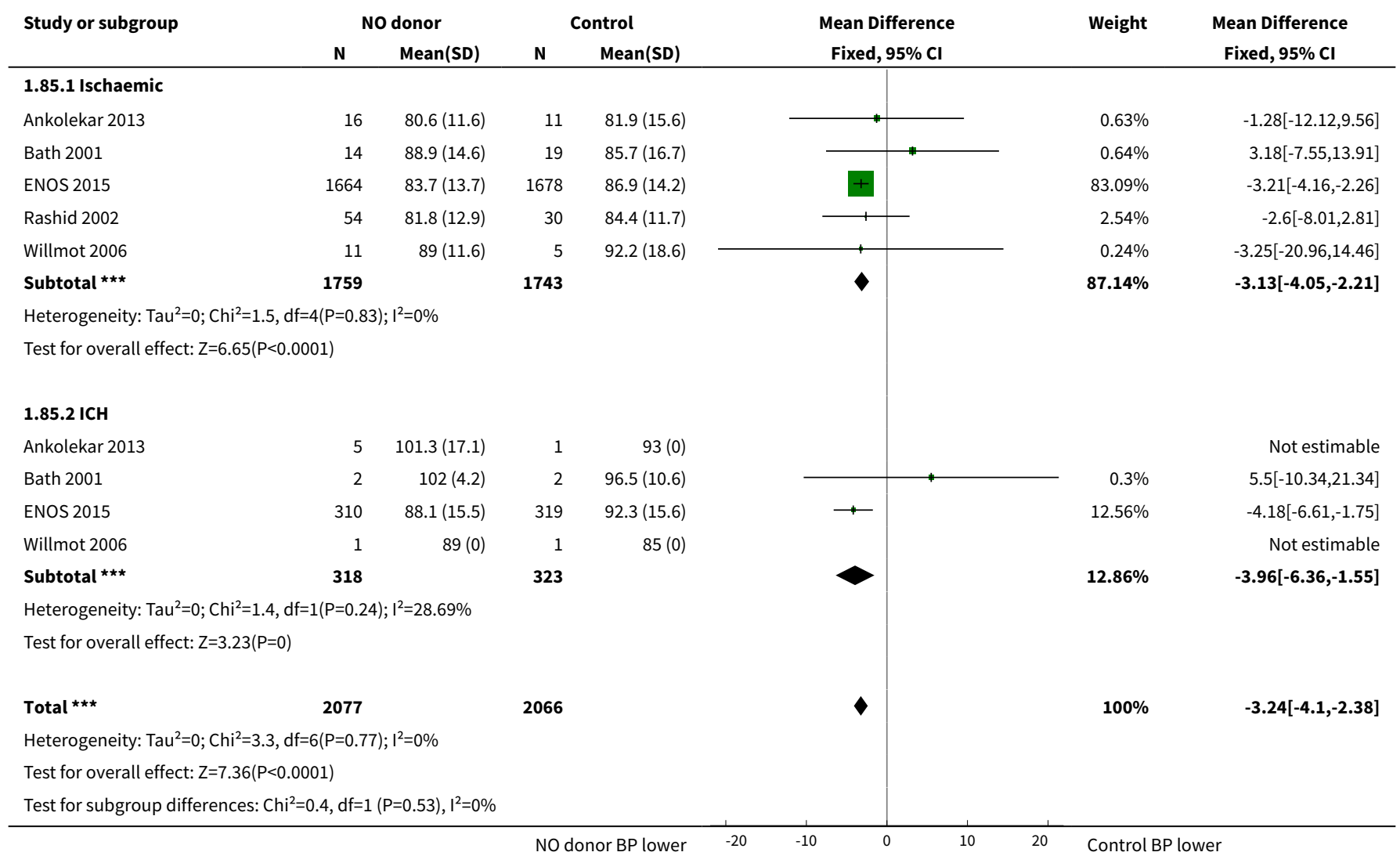

Analysis 1.86. Comparison 1 Glyceryl trinitrate (GTN) compared with no GTN for acute stroke, Outcome 86 Diastolic BP, first treatment measurement, by time to randomisation.

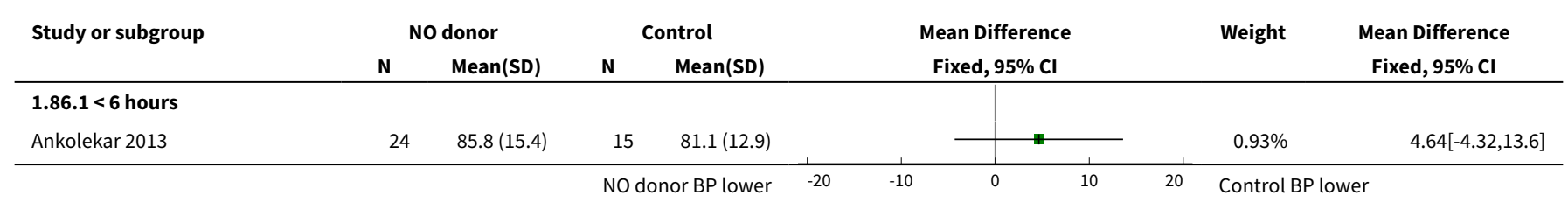




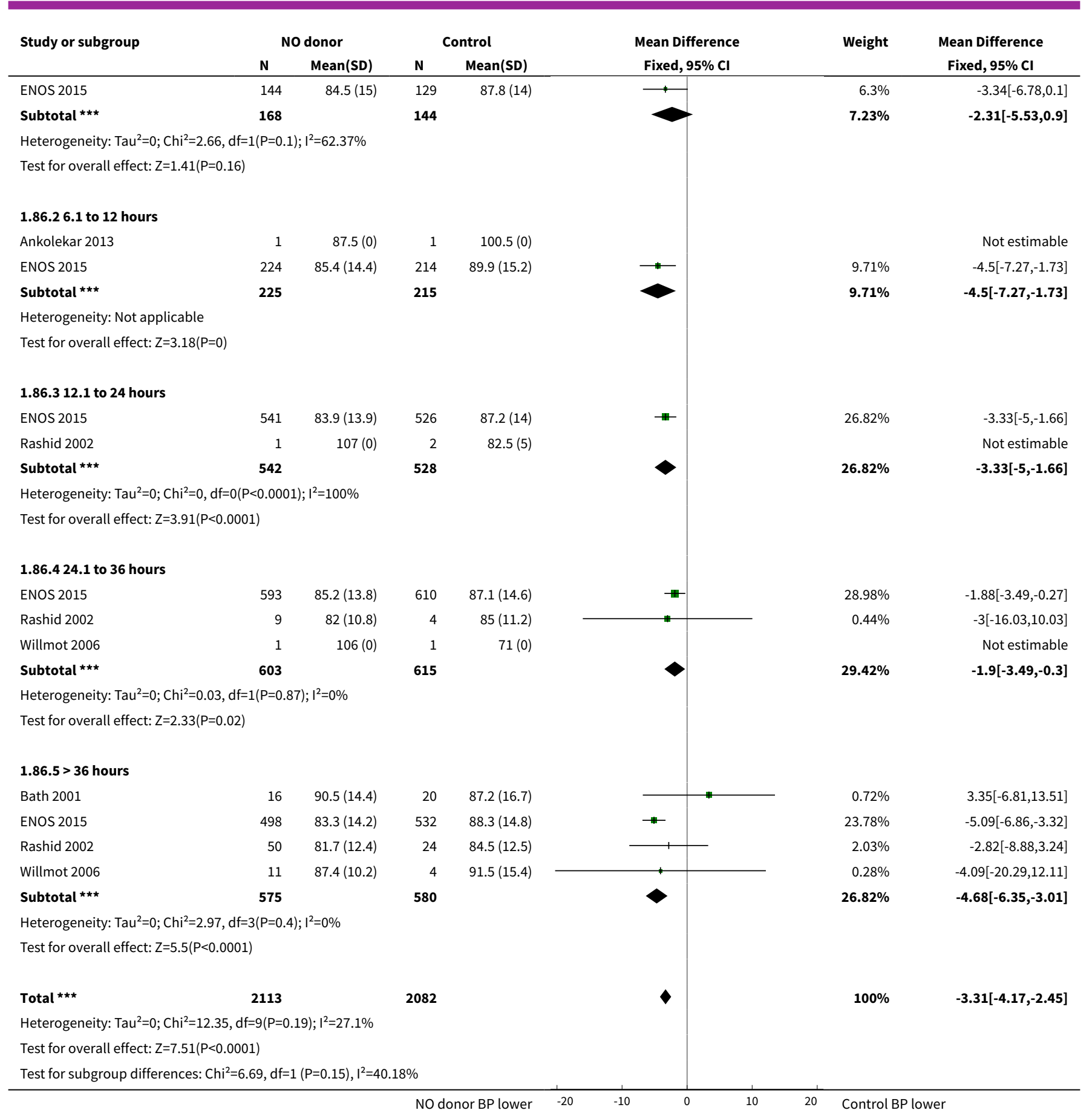

Analysis 1.87. Comparison 1 Glyceryl trinitrate (GTN) compared with no GTN for acute stroke, Outcome 87 Heart rate, first treatment measurement.

\begin{tabular}{|c|c|c|c|c|c|c|c|c|c|}
\hline \multirow[t]{2}{*}{ Study or subgroup } & \multicolumn{2}{|c|}{ NO donor } & \multicolumn{2}{|c|}{ Control } & \multirow{2}{*}{\multicolumn{3}{|c|}{$\begin{array}{c}\text { Mean Difference } \\
\text { Fixed, } 95 \% \mathrm{Cl}\end{array}$}} & \multirow[t]{2}{*}{ Weight } & \multirow{2}{*}{$\begin{array}{c}\text { Mean Difference } \\
\text { Fixed, } 95 \% \mathrm{Cl}\end{array}$} \\
\hline & $\mathbf{N}$ & Mean(SD) & $\mathbf{N}$ & Mean(SD) & & & & & \\
\hline
\end{tabular}




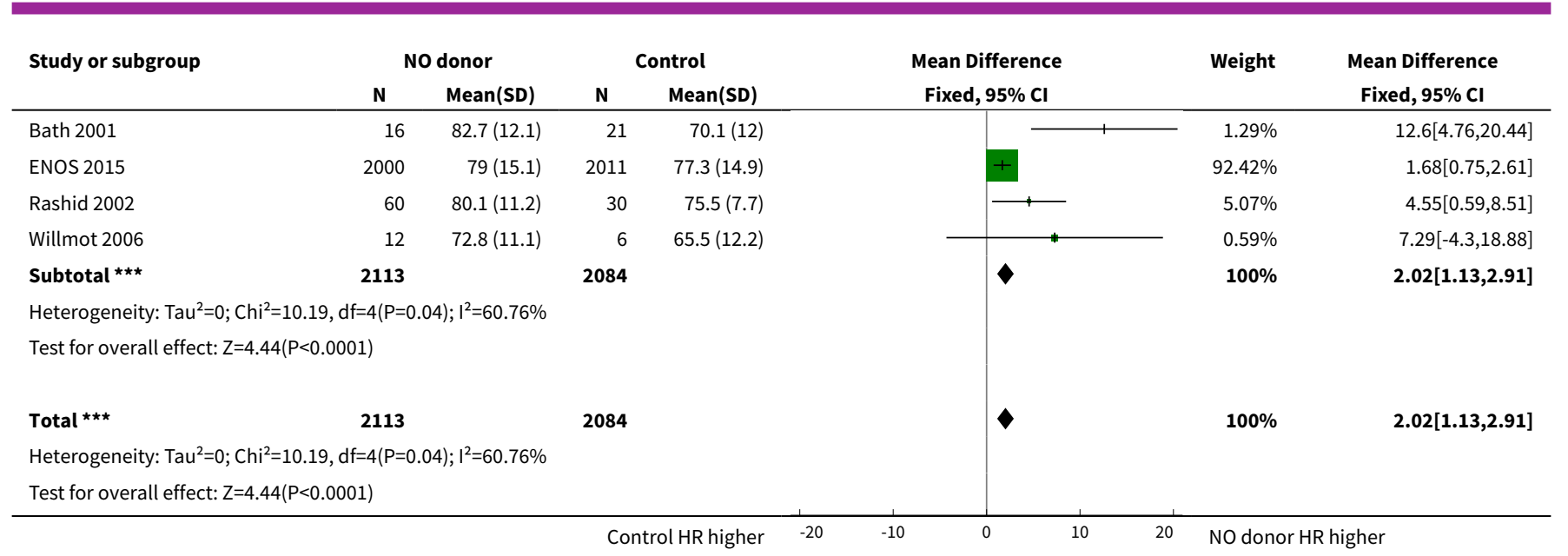

Analysis 1.88. Comparison 1 Glyceryl trinitrate (GTN) compared with no GTN for acute stroke, Outcome 88 Heart rate, first treatment measurement, by stroke type.

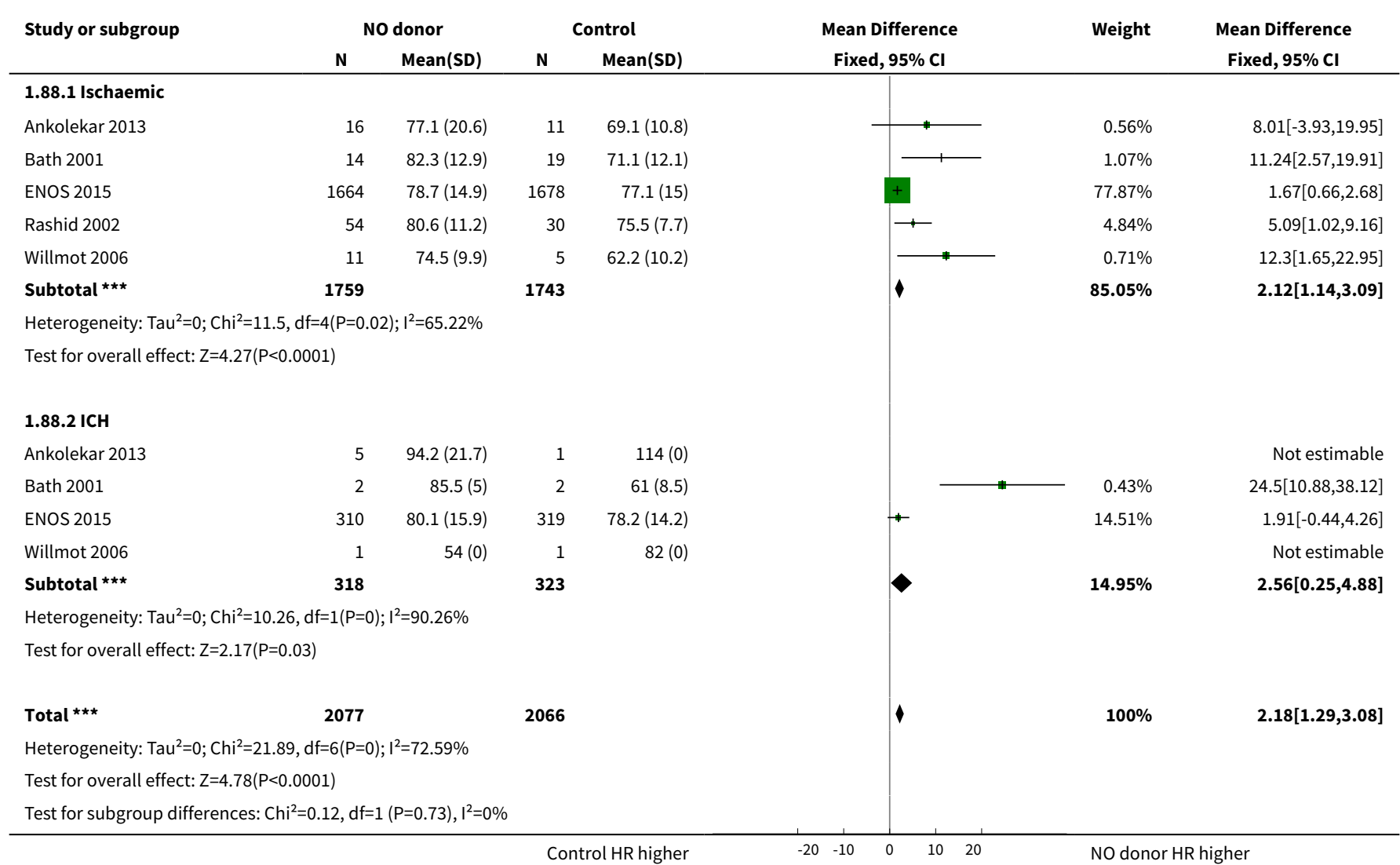


Analysis 1.89. Comparison 1 Glyceryl trinitrate (GTN) compared with no GTN for acute stroke, Outcome 89 Heart rate, first treatment measurement, by time to randomisation.

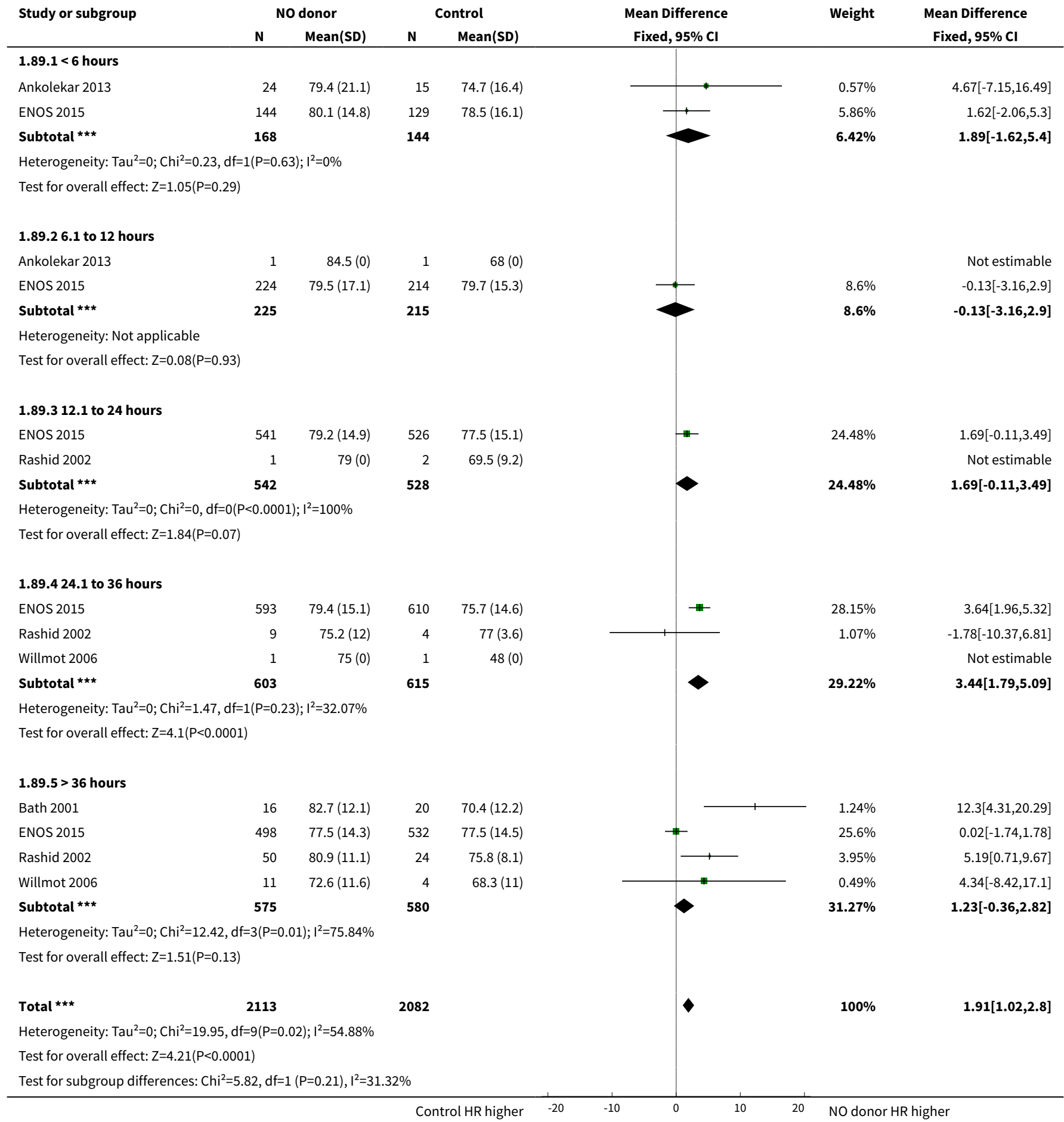




\section{A P P E N D I CES}

\section{Appendix 1. MEDLINE search strategy}

1. Cerebrovascular disorders/

2. exp Brain ischemia/

3. Carotid artery diseases/ or Carotid artery thrombosis/

4. exp stroke/

5. exp Hypoxia-ischemia, brain/

6. Cerebral arterial diseases/ or Intracranial arterial diseases/

7. exp "Intracranial embolism and thrombosis"/

8. exp basal ganglia cerebrovascular disease/

9. exp intracranial hemorrhages/

10. (stroke\$ or cerebral vasc\$ or cerebrovasc\$ or cva or transient isch?emic attack\$ or tia\$).tw.

11. (brain or cerebr\$ or cerebell\$ or vertebrobasil\$ or hemispher\$ or intracran\$ or intracerebral or infratentorial or supratentorial or middle cerebr\$ or mca\$ or anterior circulation).tw.

12. (isch?emi\$ or infarct\$ or thrombo\$ or emboli\$ or occlus\$ or hypoxi\$).tw.

13. 11 and 12

14. (brain or cerebral or intracranial).tw.

15. (h?emorrhage or h?ematoma or bleed\$).tw.

16. 14 and 15

17. 1 or 2 or 3 or 4 or 5 or 6 or 7 or 8 or 9 or 10 or 13 or 16

18. exp nitric oxide donors/

19. nitric oxide/

20. nitroglycerin/

21. Nitric-Oxide Synthase/ai [Antagonists \& Inhibitors]

22. arginine/

23. nitroprusside/

24. (nitric\$ or nitro\$ or glyceryl trinitrat\$ or GTN or arginine).tw.

25. or $/ 18-24$

26. 17 and 25

27. limit 26 to human

\section{Appendix 2. Embase search strategy}

1. Cerebrovascular disorders.mp. or cerebrovascular disease/

2. exp Brain ischemia/

3. Carotid artery diseases/ or Carotid artery thrombosis/

4. exp cerebrovascular accident/ 
5. exp brain hypoxia/ or exp brain ischemia

6. Cerebral artery disease/

7. exp occlusive cerebrovascular disease/

8. exp basal ganglion hemorrhage/

9. exp brain hemorrhage/

10. (stroke\$ or cerebral vasc\$ or cerebrovasc\$ or cva or transient isch?emic attack\$ or tia\$).tw.

11. (brain or cerebr\$ or cerebell\$ or vertebrobasil\$ or hemispher\$ or intracran\$ or intracerebral or infratentorial or supratentorial or middle cerebr\$ or mca\$ or anterior circulation).tw.

12. (isch?emi\$ or infarct\$ or thrombo\$ or emboli\$ or occlus\$ or hypoxi\$).tw.

13. 11 and 12

14. (brain or cerebral or intracranial).tw.

15. (h?emorrhage or h?ematoma or bleed\$).tw.

16. 14 and 15

17.1 or 2 or 3 or 4 or 5 or 6 or 7 or 8 or 9 or 10 or 13 or 16

18. exp nitric oxide donor/

19. nitric oxide/

20. glyceryl trinitrate/

21. Nitric-Oxide Synthase/

22. arginine/

23. nitroprusside sodium/

24. (nitric\$ or nitro\$ or glyceryl trinitrat\$ or GTN or arginine).tw.

25. or/18-24

26. 17 and 25

27. limit 26 to human

28. limit 27 to (clinical trial or randomized controlled trial or controlled clinical trial or multicentre study or phase 1 clinical trial or phase 2 clinical trial or phase 3 clinical trial or phase 4 clinical trial)

\section{Appendix 3. Web of science / Science Citation Index search strategy}

1. Cerebrovascular disorders.TI/TS

2. Brain ischemia.TI/TS

3. Carotid artery diseases or Carotid artery thrombosis.TI/TS

4. Stroke.TI/TS

5. Brain hypoxia.TI/TS

6. Cerebral artery disease.TI/TS

7. Occlusive cerebrovascular disease.TI/TS

8. Basal ganglia cerebrovascular disease.TI/TS

9. Intracranial hemorrhages.TI/TS

Nitric oxide donors (nitrates), L-arginine, or nitric oxide synthase inhibitors for acute stroke (Review) 
10. (stroke\$ or cerebral vasc\$ or cerebrovasc\$ or cva or transient isch?emic attack\$ or tia\$).TI/TS

11. (brain or cerebr\$ or cerebell\$ or vertebrobasil\$ or hemispher\$ or intracran\$ or intracerebral or infratentorial or supratentorial or middle cerebr\$ or mca\$ or anterior circulation).TI/TS

12. (isch?emi\$ or infarct\$ or thrombo\$ or emboli\$ or occlus\$ or hypoxi\$).TI/TS

13. 11 and 12

14. (brain or cerebral or intracranial).TI/TS

15. (h?emorrhage or h?ematoma or bleed\$).TI/TS

16. 14 and 15

17.1 or 2 or 3 or 4 or 5 or 6 or 7 or 8 or 9 or 10 or 13 or 16

18. nitric oxide donor.TI/TS

19. nitric oxide.TI/TS

20. glyceryl trinitrate.TI/TS

21. Nitric-Oxide Synthase.TI/TS

22. arginine.TI/TS

23. nitroprusside sodium.TI/TS

24. (nitric\$ or nitro $\$$ or glyceryl trinitrat\$ or GTN or arginine).TI/TS

25. or/18-24

26. 17 and 25

27. 26 Refined by: DOCUMENT TYPES: (CLINICAL TRIAL)

WHAT'S NEW

\begin{tabular}{lll}
\hline Date & Event & Description \\
\hline 7 September 2016 & New search has been performed & $\begin{array}{l}\text { Addition of three new trials with 4070 participants. In total, five } \\
\text { trials with 4197 participants are now included in the review. We } \\
\text { have added subgroup analyses and new outcomes, and updated } \\
\text { the Background. }\end{array}$ \\
\hline 7 September 2016 & $\begin{array}{l}\text { New citation required and conclusions } \\
\text { have changed }\end{array}$ & $\begin{array}{l}\text { With the addition of new data we conclude that glyceryl trini- } \\
\text { trate (GTN) does not alter outcome overall in acute stroke. When } \\
\text { administered within six hours, GTN may improve clinical out- } \\
\text { comes and therefore warrants further study. }\end{array}$ \\
\hline
\end{tabular}

\section{H I S T ORY}

Protocol first published: Issue 3, 1996

Review first published: Issue 1, 1998

\begin{tabular}{lll}
\hline Date & Event & Description \\
\hline 4 September 2008 & Amended & Converted to new review format. \\
\hline
\end{tabular}




\begin{tabular}{lll}
\hline Date & Event & Description \\
\hline 13 August 2002 & New search has been performed & $\begin{array}{l}\text { Data from two trials have been added. The review has been ex- } \\
\text { panded to include patients with primary intracerebral haemor- } \\
\text { rhage (as well as ischaemic stroke). }\end{array}$ \\
\hline
\end{tabular}

\section{CONTRIBUTIONS OF AUTHORS}

- PM Bath: conceived, designed and coordinated the review; developed the search strategy for the previous reviews; interpreted data; wrote the review; and is guarantor of the review.

- JP Appleton: updated the search strategy; performed data collection, collation and analysis; interpreted data; co-wrote the review.

- K Krishnan: checked and interpreted data; co-wrote the review.

Previous versions of the review involved:

- Richard Butterworth: undertook searches; entered data;

- Mark Willmot: provided advice on the review; co-wrote the review;

- Jo Leonardi-Bee: analysed individual patient data from two trials;

- Fiona Bath-Hextall (supported by South Thames \& Trent NHS R\&D Executive): coordinated the review; undertook searches; was responsible for data management; entered data.

\section{DECLARATIONS OF INTEREST}

- PM Bath was chief investigator for the five included trials (Ankolekar 2013; Bath 2001; ENOS 2015; Rashid 2002; Willmot 2006) and is chief investigator of the ongoing RIGHT-2 2015 trial; he was Wolfson Foundation Senior Lecturer in Stroke Medicine, and is Stroke Association Professor of Stroke Medicine, and a NIHR Senior Investigator.

- JA was funded by the British Heart Foundation (RIGHT-2 2015 trial).

- KK was funded by the Medical Research Council (ENOS 2015 trial).

\section{SOURCES OF SUPPORT}

\section{Internal sources}

- No sources of support supplied

\section{External sources}

- NHS South Thames Region Research and Development Programme, UK.

- Stroke Association, UK.

- Wolfson Foundation, UK.

\section{DIFFERENCES BETWEEN PROTOCOLANDREVIEW}

The methods of the present review have been substantially updated since the initial publication of the protocol in 1996 to include multiple secondary clinical outcomes and utilisation of individual patient data where available.

\section{N DEX TERMS}

\section{Medical Subject Headings (MeSH)}

Acute Disease; Arginine [ ${ }^{\star}$ therapeutic use]; Brain Ischemia [drug therapy]; Enzyme Inhibitors [ ${ }^{\star}$ therapeutic use]; Headache [chemically induced]; Nitric Oxide Donors [adverse effects] [ ${ }^{\star}$ therapeutic use]; Nitric Oxide Synthase [ ${ }^{\star}$ antagonists \& inhibitors]; Nitroglycerin [adverse effects] [^therapeutic use]; Quality of Life; Randomized Controlled Trials as Topic; Stroke [^drug therapy] [mortality]

\section{MeSH check words}

Humans 